\title{
BEGINNINGS IS
}

ANIMAL HUSBAYDRY C.S.PLUMB.

(c)

(4)

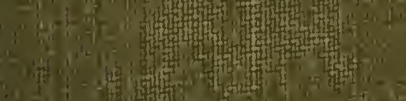

(2) 47

thes

3. 
THE LIBRARY

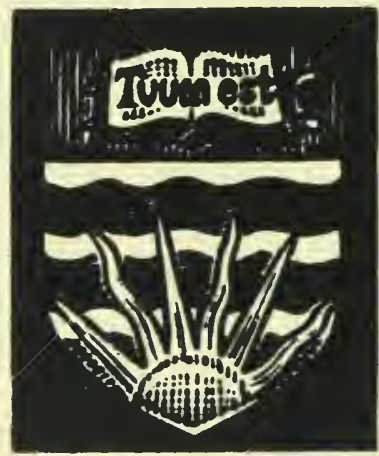

\section{THE UNIVERSITY OF BRITISH COLUMBIA Gif!}

In Memory
of

James G. Davidson 
Whendisben $x+7$ 



\section{Beginnings in Animal Husbandry}

\section{Farm Science Series}

Beginnings in Animal Husbandry

By C. S. Plumb, Ohio State University

\section{Field Crops}

By A. D. Wilson, University of Minnesota

and C. W. Warberton, U. S. Department of Agriculture

Soils and Soil Fertility

By A. R. Whitson, University of Wisconsin

and $H$. L. WALster, University of Wisconsin

Agricultural Engineering

By J. B. Davinson, Iowa State College of Agriculture and Mechanic Arts

\section{Popular Fruit, Growing}

By S. B. Green, University of Minnesota

Vegetable Gardening

By S. B. Green, University of Minnesota

(OTHER VOLUMES IN PREPARATION) 


\section{BOOKS WRITTEN BY CHARLES S. PLUMB}

A Biographical Directory of American Agricoltural Scientists

Edited and published at Knoxville, Tenn., 18s9; pp. 100;

flexible cloth. The supply of these is exhausted.

Indian Corn Culture

Chicago: The Breeders' Gazette Print, 1895. Cloth; pp. 243; figs. 63.

Little Sketches of Fayous Beef Cattle

Columbus, Ohio: Published by the author, 190t. Cloth; pp. 99.

Types and Breeds of Farm Animals

Boston: Ginn \& Co., 1906. Cloth; pp. 563; figs. 256.

A Partial Index to Animal Husbandry Literature

Columbus, Ohio: Published by the author, 1911. Cloth; pp. 94. 
Digitized by the Internet Archive in 2010 with funding from University of British Columbia Library 


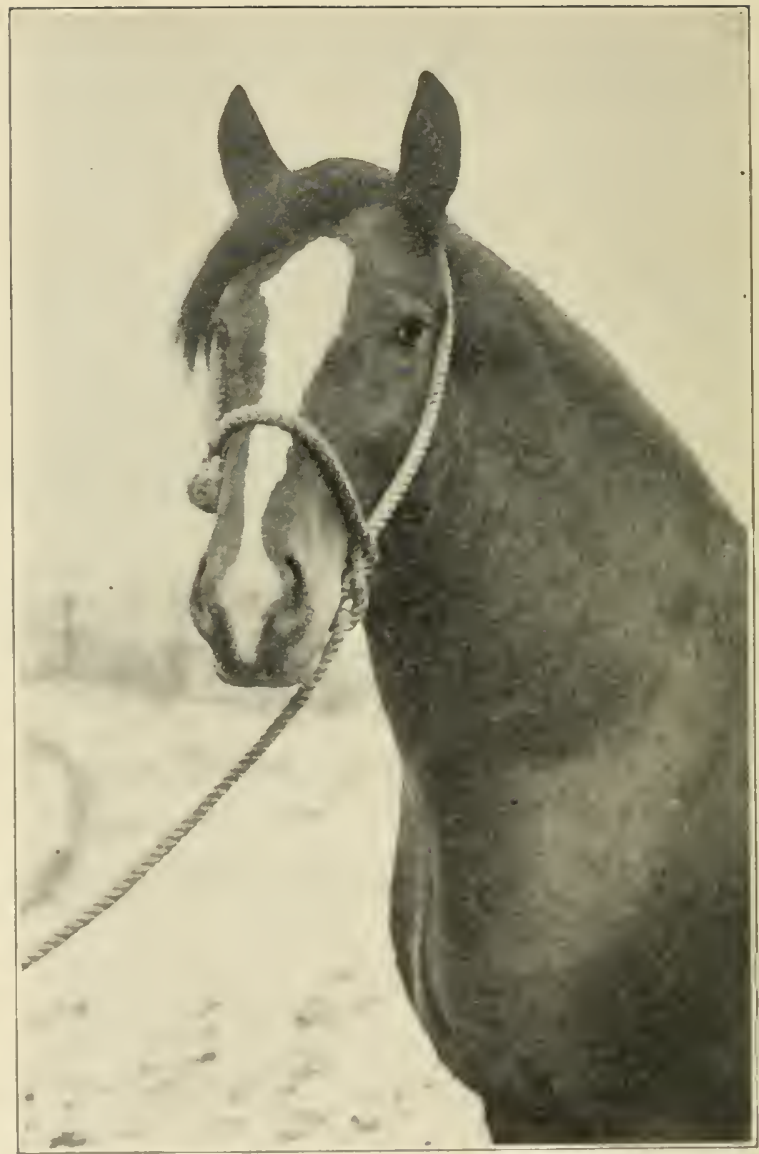

Bhotugraph by courtesy Michay I3ros.

"For should I speake rather like a Philosopher than a Christian, I could not but agnize nature to bee admirabie in all her workes, uherein man doth ou'e unto her intinite, and those 'ery great thankes, in that shee hath uccommodated and pientifully lurnished him with all things ne'edlull for his use, as also ln that she' hath him with all things ne'dfill for his use, as also in that she' hath service of man, and who best acknouledgeth his Master."

- Thomas de Grey, 1651. 


\title{
BEGINNINGS IN
}

\section{ANIMAL HUSBANDRY}

\author{
$\mathrm{BY}$ \\ CHARLES S. PLUMB \\ Profegsor of Aximal Husbandry in the College of Agriculture \\ of the Ohio State University
}

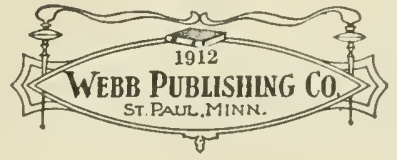


COPYRIGHT, 1912

By CHARLES S. PLUMB

ALL RIGHTS RESERVED 


\section{FOREWORD}

Agricultural education in America is comparatively new. Previous to 1870 but few colleges of agriculture existed in this country. During the period between 1870 and about 1890 , interest was awakened in this field of education. Many of the agricultural colleges graduated their first classes along in the seventies. Excepting a few men who had been trained in chemistry, as applied to agriculture, there were almost no instructors who had received what we now regard as an agricultural education. The instruction known as agricultural, then consisted of lectures on familiar farm practices, frequently supplemented by manual labor on the part of the student. Text books were few, and the preparation of new ones was slow.

Agricultural education under these conditions lagged, and how to encourage interest became a serious problem with the colleges. Educators insisted that the teaching should be largely based on pure science, and it was often difficult for the students to see the application.

Recognizing this lack of interest, a few Western colleges conceived the plan of giving short winter courses of a popular nature, in which practical laboratory instruction should be given. Work in dairying, horticulture, and live stock judging first received attention. This practical training was most favorably regarded by the students. These winter courses grew rapidly in popularity, and paved the way for more attractive forms of instruction for the regular students. Through this medium of the short winter enurse, both inter- 
est and attendance in the agricultural colleges rapidly grew. New courses of study were established, more buildings and equipment were required, and then agricultural education sprang into popularity. The production of new types of text books, on subjects heretofore undiscussed in pedagogical form, logically followed in this evolution in agricultural education.

During this movement in behalf of rural uplift, a few progressive men urged the importance of agricultural edueation in the country schools of higher grade. This resulted in establishing agricultural schools of secondary grade in different parts of the United States, both North and South. During the past few years, country life has become popular. As a result, there is a widespread movement in behalf of agricultural education, and the subject is now being taught in its various phases in many schools all over the land.

Recognizing the need of an elementary text book for young people, the author has seen fit to prepare this volume on animal husbandry, the first of its kind deroted to this special field. It is his earnest hope that such lessons as either teacher or pupil shall find within these pages, may result in a desire for yet wider knowledge of and a more sympathetic interest in our farm animals.

Charles S. Plumb.

Ohio State University,

Columbus, Ohio,

November 1, 1912. 


\section{CONTENTS}

Chapter

I. The Iuportance of Animal Husbandry

II. The Breeds of Horses . . . . . . . 23

III. The Breeds of Cattle . . . . . . . 46

IV. The Breeds of Sheep . . . . . . . 74

V. The Breeds of Swine . . . . . . . 99

VI. Animal Type and Its Importance . . . . 114

VII. Reasons and Methods in Judging Live Stock • 125

VIII. The Points of the Horse . . . . . . 138

IX. Judging the Horse . . . . . . . $15 \mathrm{~S}$

X. The Judging of Cattle . . . . . . 173

XI. The Judging of Sheep . . . . . . . 196

XiI. The Judging of SWine . . . . . . . . 209

XiII. Heredity: Its Meaning and Influence • . 221

X IV. Selection and Its Importance . . . . . 230

XV. Pedigrees and Their Valde . . . . . 240

XVI. Suggestions to Young Breeders . . . . 248

XVII. The Composition of Plants and Animals • . 257

XVIII. The Influence of Foods on the BodY • • . 265

Xix. Feeding Standards: Their Origin and Use . 274

XX. How to Calculate a Ration . . . . . 281

XXI. Coarse Feeds and Their Value . . . . 288

XXII. Concentrated Feeds and Their Value . . . 303

XXiII. The Care of Farm Animals . . . . . . 313

XXIV. Types and Breeds of Poultry . . . . . 325

XXV. Judging Poultry and Poultry Products • • 340

XXVI. EgGs and Incubation . . . . . . . 349

XXVil. The Feeding of Poultry . . . . . . 360

XXVIII. Poultry Houses ANd Equipaent . . . . 374 



\section{BEGINNINGS IN \\ ANIMAL HUSBANDRY}

CHAPTER I

\section{THE IMPORTANCE OF ANIMAL HUSBANDRY}

The study of domestic animals may be considered both a pleasure and a duty. A pleasure, because of the naturalborn interest man feels in all animals; and a duty, on account of the service horses, cattle, sheep, and swine play in the world's affairs. Between many people, and even nations,

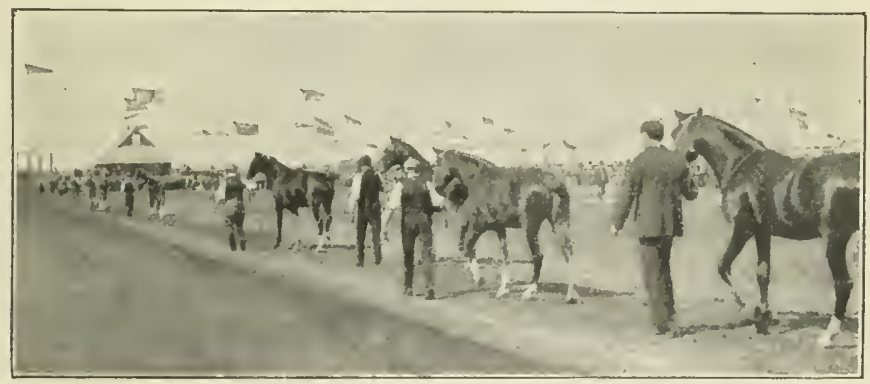

Fig. 1. A view at the Royal Agricultural Society Show of England. Photograph by the author.

and their domestic animals, we find an affectionate, sympathetic relationship. The people of Great Britain, the world's leading stockmen, from the King and Queen to the humblest laborer, show a keen and kindly interest in everything relating to farm live stock. One of the most interesting 
sights to be seen in Europe is the annual show of the Royal Agricultural Soeiety of England, where live stock is made the leading feature, and where vast throngs of people go to inspect and talk over the animals and watch the judges at their work. The average Britisher is a lover of animals, and expresses a common, inherited sentiment. This disposition on the part of a people, develops the finer, more sympathetic qualities, and broadens and strengthens character. In the same way, the boy or girl who shows a devotion to the animal given to his or her care, becomes finer, more sympathetic, and broader minded, and is renderedmore resourceful and capable. From another point of view, animals play a most important part on aceount of their uses for food and labor. Therefore, the study of animals as relating to farm economy and the markets of the world becomes a most important matter.

The commercial value of the live stock industry is so great that only a brief reference can be made to it here. One is unable to comprehend the magnitude of the figures which relate to either numbers or values of farm animals.

The thirteenth United States census, for 1910, reports the following numbers and values as applied to animals on our farms for that year.

\begin{tabular}{|c|c|c|}
\hline Class of S'TOCK & Number & VALUE \\
\hline Horses. . . . . . . & $19,731,000$ & $\$ 2,076,000,000$ \\
\hline & 4,28 & 522 \\
\hline & 61,2 & $1,48.5,000,000$ \\
\hline & 52,4 & $209,536,000$ \\
\hline vine. & $58,186,000$ & $615,170,000$ \\
\hline In & $0,0 \cdot 1,000$ & $10 s, 100,00$ \\
\hline
\end{tabular}

By these figures we see that we had in 1910 almost 200 million animals on our farms, and that they were valued at over four billion dollars, a sum far too big to comprehend. 
The significant thing is simply to realize the vastness of our live-stock industry, and the enormous sum of money here invested, besides the value of the animals themselves. The greatest live-stock producing section of the country includes the states of New York, Olio, Indiana, Illinois, Michigan, Wisconsin, Minnesota, Iowa, Missouri, North Dakota, South Dakota, Nebraska, Kansas, and Texas. The two states of most importance in numbers of each kind of live stock in the United States in 1910, are as follows:

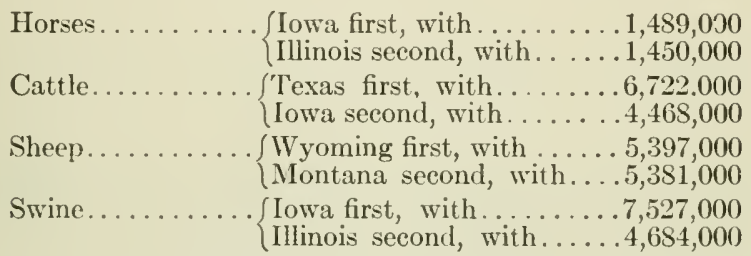

We see from the above that Iowa ranks first in numbers of horses and swine, and second in cattle, which gives this state the leading position in live-stock production; Illinois holds a close second place.

The importance of our live stock may also be seen from another point of view in connection with our local markets. The city of Chicago is the largest live-stock market in the world. The Union Stock Yards of that city cover 500 acres, and received in 1911 a total of $161 / 3$ millions of farm animals, valued at about 340 millions of dollars. Nearly 272,000 car loads of live stock were received in these yards in 1911. This is equal to 745 cars a clay. At an average length of 34 feet to a car, these cars would make one solid train of live stock about $43 / 4$ miles long. There are 300 miles of railway in and about the yards to handle all this great traffic. Some 50,000 people live about the yards and get their daily incomes from them. Here are immense 
slaughter houses and meat packing plants, from which meats are shipped to all parts of the world. The Union Stock Yards and packing houses are noted features of the great city of Chicago, and are daily visited by tourists from all over America and many other countries. In 1909 there were 1641 slaughtering and meat-packing plants in the United States, in which were killed and prepared for food, over a billion dollars worth of farm animals. These figures are given simply to show something of the importance of the

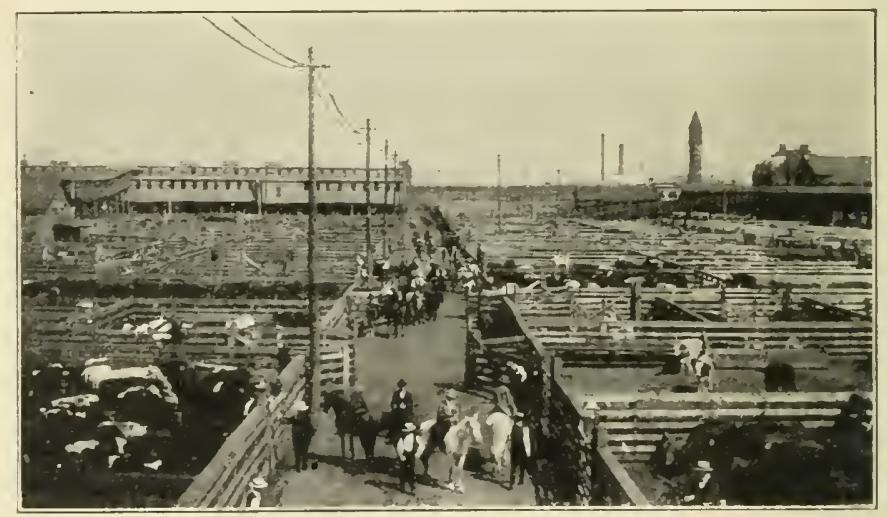

Fig. 2. A riew in the Union Stock Yards, Chicago. Photograph by courtesy The Farmer.

live-stock trade and of the part it must play in American agriculture.

The first use of animals by man dates back to the days when there was no civilization, when no written records were made, and the people lived as ignorant savages. This was in prehistoric times, when the only implements used were very crude ones made by hand, of stone, iron, or copper. That animals lived with man in these prehistoric days, we know, breause the bones of man, and those of horses, cattle, 
and other animals have been found mingled together in the remains of prehistoric villages in Europe. As man ascended in the scale of civilization, we find that animals became more and more associated with him in his daily life. The oldest historical works make frequent reference to farm animals. If one consults the Bible he will find in the Book of Genesis, dating back over 2000 years before Christ, repeated reserence to herdsmen and horses and asses, cattle, shcep, and goats. In fact, these people of early days were farmers, and depended largely on their live stock.

The importance of domestic animals to man is to be seen in several ways. There are some features of special interest to the student; namely, (a) the usc of animals for clothing, (b) for food, (c) for labor, and (d) in relation to maintaining soil fertility. Each of these is of sufficient importance to justify special consideration.

The use of animals for clothing refers to the skin, hair and wool or other hairy covering. Earliest man is supposed to have used the skins of animals for clothing, especially in the cooler regions or colder parts of the year.

For thousands of years people have woven eloth from wool, and the hair of eamels and goats. At the present day the making of cloth from wool is a great industry in different parts of the world. Millions of sheep even now have their chief value in the wool that they produce. The leading industry of a number of English and American towns and eities is the converting of wool into clothing; so we find there great mills employing thousands of people.

The use of animals for food is of first importance. It is for this that cattle, sheep, and swine have been domesticated; and the final end of all farm animals except the horse, ass, and mule, must be for human food.-- Meat is a concentrated food, rich in the substances that give strong physical 
development. It is said that the meat-eating nations rule the world; and when we realize that the people of North Ameriea, Great Britain, France, and Germany are the greatest consumers of this food, we are inclined to believe the statement to be true. The average person in the United States eats about 180 pounds of meat a year. With a population approaching one hundred million people, it can be easily understood that an enormous number of animals must be slaughtered for food each year.

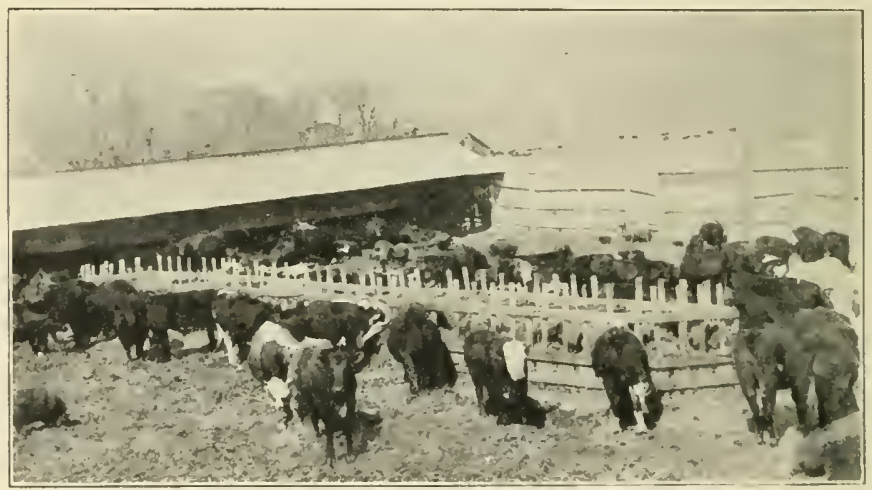

Fig. 3. Fattening cattle in a Western feed lot. Photograph by courtesy The Farmer.

There is also another important source of food from animals, that of milk and its products. Cattle have been so improved since domestication began, that today we have cows producing remarkable yields of milk. A yield of 5000 pounds of milk a year is very common; a large number of cows have produeed 10,000 pounds; a yield of 15,000 pounds of milk in a year from a single animal is no longer remarkable. Milk is a very nutritious liquid food, and supplies a place in human diet as does no other substance. From milk is 
manufactured cheese, a valuable food that in Europe very generally takes the place of meat among the laboring elasses. Butter, also a product of milk, is so greatly in demand that thousands of creameries engage in its production. In 1910, there were twenty million eows and heifers kept in the United States, primarily for milk. Five states had over one million dairy cows each.

The use of animals for labor, no doubt dates from prehistorie days when man subdued the horse. With the eulti-

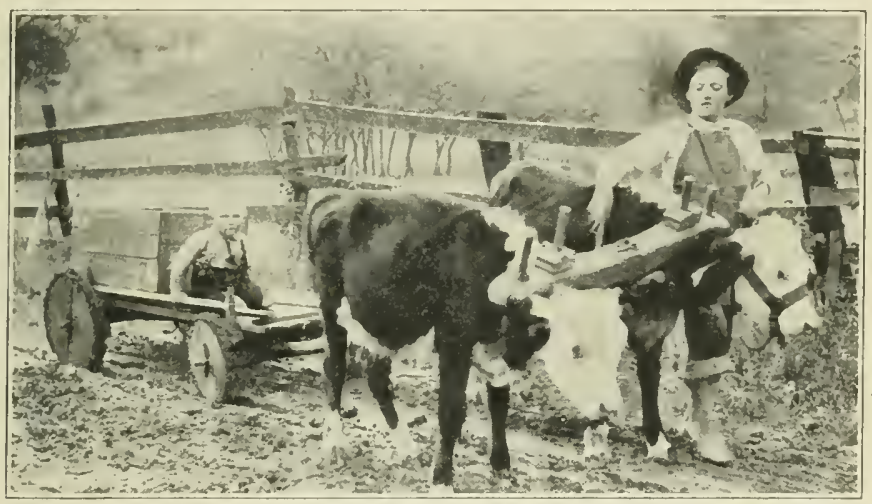

Fig. 4. A miniature ox team in West Virginia. Photograph by Warren Booker.

vation of the fields, both eattle and horses beeame beasts of burden and laborers in the fields. Cattle are eommonly used for labor in parts of Europe, even dairy cows sometimes being employed to draw loads. Oxen were much used in pioneer days for draft work in America, but have been generally discarded on aecount of their slowness, yet even today they may be seen serving in place of horses in some parts of our eountry. In the pioneer settlement of Ameriea, the ox team proved a very important means of transporta- 
tion through the forests and across the wide Western prairies. The great endurance, steady habits, and ease of keep, make the ox a favorite with the pioneer.

In countries other than our own, where railways do not exist, the transportation of freight must be done by animals, or on the shoulders of men. In many countries the people use the backs of animals for this purpose. In northern Africa, the camel is known as "the ship of the desert," for on his back is carried both man and freight from the interior to the coast. In parts of Asia, the elephant becomes a mighty beast of burden, performing wonderful draft service. The little donkey, regarded in America as simply a plaything for children, is widely used over the world as a burden bearer. Thus we see that domestic animals, even today, play a very important part in moving merchandise and performing labor. Although modern methods of transportation care for enormous quantities of freight, the fact is that the clemand for the work horse does not diminish. The draft work on our farms must be very largely accomplished by the horse; while even in the eity, in spite of the expensive motor truck, the horse is considered indispensable in a large amount of business. Professor T. F. Hunt states* that in England it is estimated that two horses will cultivate 80 acres of light and sandy soil, or 60 acres of heavy, or clay, soil. In the United States, it appears that one horse or mule of working age is kept for every 30 acres of improved land; but in level prairie sections, far more service than this indicates is expected.

The use of domestic animals in maintaining soil fertility has long been recognized as of great importance. The earliest writers on agriculture, who lived just prior to the Christian era, about two thousand years ago, wrote more or

*Cyclopedia of Agriculture, Vol. III, 1908, p. 11. 
less of the value of manures in keeping the soil fertile. The farmer of those days learned from experience that if he took a crop from the land one year, that the next harvest from the same soil would be smaller unless manure was used to replace the fertility removed in the crop. Thus we see that 20 centuries ago the farmer learned that he must replace fertility in his soil if he expected to reap abundant harvests. To secure this necessary fertility, he used the manure provided by farm animals; and much was written about the value of the excrement from different kinds of animals, and the preservation of manures.

In very recent times, artificial fertilizers have come into extensive use. But in spite of this fact, the natural manures of animals have been absolutely necessary to keep up the fertility of the soil of most regions where high-class farming is practiced. There are lands in Europe today, said to have been cultivated for 2000 years, that grow great crops, made possible by the use of animal manures. This statement may be accepted as a fact, that, except in the case of some great river valleys, like the Nile, which are enriched by annual overflow, no agricultural region has continued to grow abundantharvests without the aid of manure from domestic animals. Each year the wheat fields of Canada and the corn fields of the Mississippi Valley yield in reduced amounts per acre, unless fertility replaces that removed by the crop. Experience has also shown that where farmers keep the most live stock, there the crops are most abundant and the people most prosperous.

We purchase commercial fertilizers to restore fertility to the soil; but these lack one thing of great importance found in stable manures, and that is vegetable matter, which is as necessary to the soil as is the chemical nutriment. The rotted manure in the soil makes it more porous and mellow 
and permits the entrance of air and the growth of roots through it more freely than occurs where no vegetable mould is present. Interesting experiments conducted for more than 70 continuous years on the same land, in England, at Rothamsted experiment station, showed that wheat grown on unmanured land yielded just about 12 bushels per acre, while a yield of about 40 bushels occurred where stable manure was used. A ton of average stable manure is considered to contain about $\$ 2.50$ worth of plant food. Professor Roberts has figured ${ }^{*}$ that the average value of the manure produced by a cow each day is eight cents, while that of a horse is worth about a half cent less. The value of stable manure, however, depends upon the feed the animal gets. Feed rich in grain makes a more valuable manure than that from hay only, and so will return more fertility to the soil.

The animal is a machine for changing coarse into fine material. The ideal kind of farming combines the growing of grass and grain and the feeding of these to the animals of the farm. These raw crops are thus converted into concentrated and high priced products, as represented in meat, milk, butter, cheese, or breeding stock. A large percentage of the food consumed returns to the farm to keep up its fertility. Some forms of stock farming remove but very little of the actual soil fertility. One reason why dairycattle farming meets with so much favor is because of the small amount of fertility sold from the farm in milk or butter. Professor Vivian states ${ }^{\dagger}$ that the fertilizing value of a ton of butter is but $4 t$ cents, and that 5000 pounds of milk contain but $\$ 4.89$ worth of fertility. As much as 80

* Bulletin 56, Cornell University experiment station.

$\uparrow$ First Principles of Soil Fertility, 1908, p. 120-121. 
or 85 per cent of the value of the food or crop becomes animal excrement, and thus is returned to the soil for its up-building.

When, as in case of dairy-cattle farming, much more grain is fed than is grown on the farm, then the land steadily improves in its producing eapacity. The best examples of intelligent general farming are to be found where herds and flocks are kept as important features of a well-balanced farm system. Where the special business is stock farming, then the final product in its concentrated form will yield far

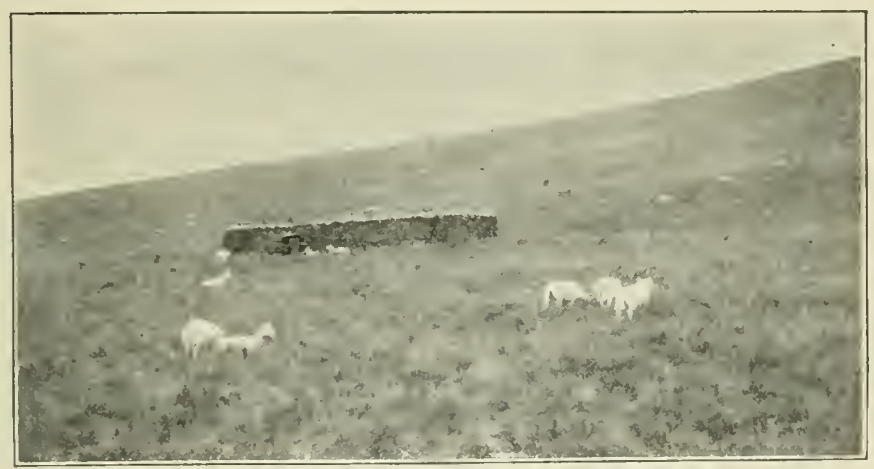

Fig. 5. Sheep on a Scotch mountainside, with no vegetation but grass. Photograph by the author.

more important and profitable returns in the long run than will any other method. One hundred acres of grain shipped a thousand miles require a large expenditure of labor and money, while this same crop, in the form of a concentrated product like butter or meat, may be transported at relatively much less expense.

Stock farming is adapted to the cheaper and rougher lands. Much land that might not be used for other purposes can be devoted to pasturing farm animals. The grass on the 
hills is usually finer and sweeter than on the lowlands. In various parts of the world where the land is naturally poor or of a rough character, stock farming is an important industry. In fact, no other kind of farming is so well adapted to these conditions. On the Cheviot Hills of Scotland, the prineipal industry is that of sheep raising, grass and sheep being the two crops. In Switzerland, high up on the mountain sides are pastures which annually furnish feed for many dairy cows. On the rough, cheap hillsides of New England, dairy cattle are the most important source of income to the farmer. On the high, grassy hills of eastern Ohio, western Pennsylvania, and West Virginia, are to be found the largest flocks of sheep in this country east of the Missouri River.

In the Southwest and far West of the United States, on the cheaper rolling or broken lands, will be found extensive herds and flocks. In the Northwest, among the cut-over lands that have been deprived of their timber by the lumbermen, dairy cattle and dairymen are being developed on a greater scale than elsewhere in America. In fact the farmer generally plans on the use of his cheaper, poorer lands as pasture for stock. Rightly handled, these lands in most cases greatly increase in producing capacity and value. Inasmuch as live stock also finds an appropriate place on the more fertile and level farms, we must recognize the fact that animals are adapted to greater extremes of soil and land conditions than are the staple crops. Thus animals in a worldwide sense become subjects of great importance and interest. 


\section{CHAPTER II}

\section{THE BREEDS OF HORSES}

The origin of the horse was for many years not well understood. It used to be thought that the domestic horse was descended from the wild ass that lived in Africa and Asia. It is now pretty well agreed that the horse of today is descended from animals that lived in past geological times. Fossil remains of horses have been found in different parts of North and South America and in Europe. These are known as prehistoric horses, because they lived on the earth before man left any recorded history.

The prehistoric horse in the earliest geological times, say three million years ago, was very small. He was probably about as big as a fox terrier, and is known as the "dawn horse." During the development of the earth's surface, the prehistoric horse passed through gradual and very important changes. There was an increase in size, and his body, legs, and head became more and more like those of the modern horse. Many parts of the skeletons of these early horses have been found in North America, especially in the far West, in Wyoming and the Bad Lands of that section. Scientific men have put the fossil parts of these horses together so completely that their development is clearly understood. From this first period up to the last, skeletons more or less complete have been found, showing the gradual increase in size and change of character through which this prehistoric horse passed.

So we know that the horse has liven in America for millions of years. Just when the first domesticated ones 


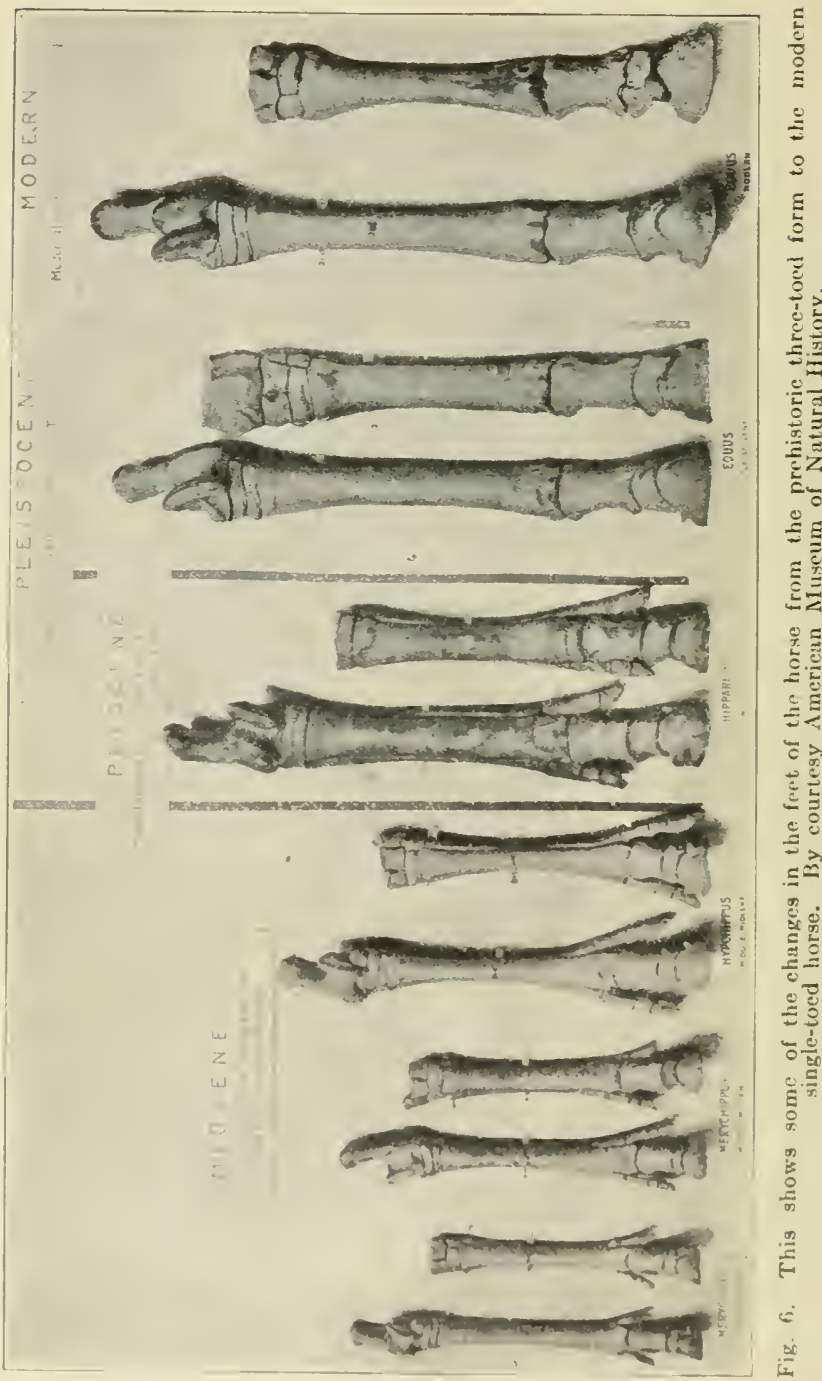


developed here, however, we do not know unless from those brought here from Europe by Columbus and the early explorers.

How human beings came to use the horse, we do not know. It is thought that man first used wild ones for food,

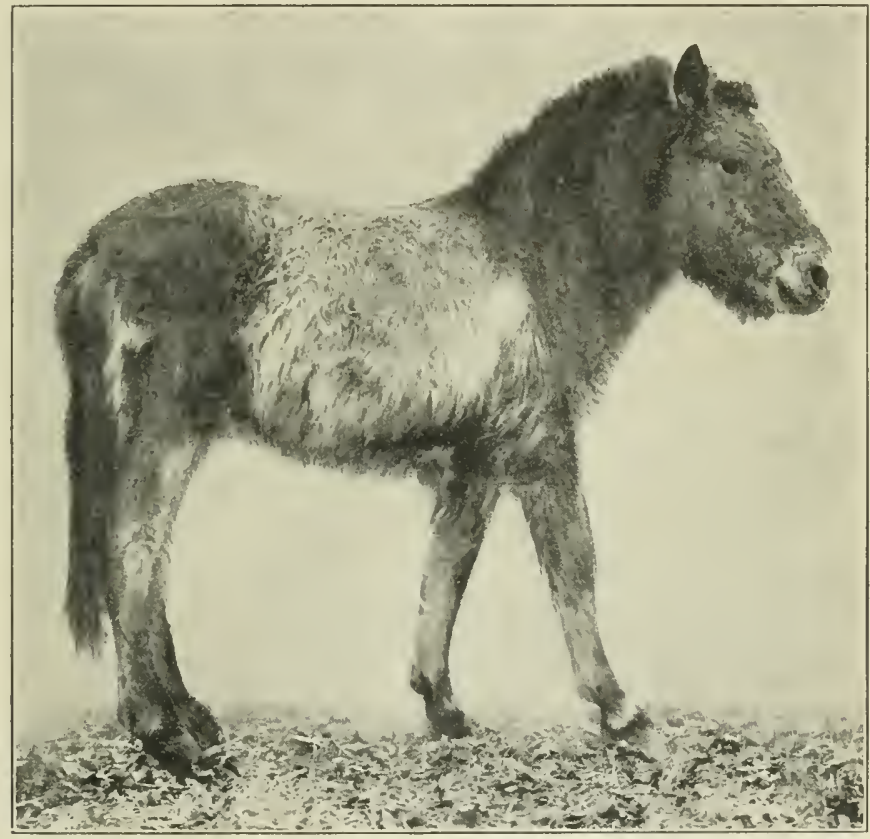

Fig. 7. A wild pony captured in central Asia, owned by the New York Zoological Park. Photograph by courtesy Dr. W. T. Hornaday, Director.

and later for carrying burdens. We have some forms of ponies at the present time that are supposed to be elosely related in appearance to the more recent prehistoric horse. Some years ago in central Asia, true wild horses of pony size 
were discovered by a famous Russian explorer. These and the rough ponies of Iceland and northern Europe are probably elosely related to the latest form of prehistoric horses.

The development of the breeds of horses has been due to different conditions. Climate, food, and man, have each had a very important influence. A mild climate and abundant food no doubt caused the horse to become gradually larger than where the elimate was cold and food not abundant. The Shetland pony comes from a region in the North Sea where the weather is very severe and food is never plentiful. So this pony on its native island is very small. In his American home, however, on the Western prairie, where food is abundant, and the climate mild, he develops into a greater size. The horses from hot climates have always been more active than those from cold. Thus in northern Africa the Arab horse has developed into an animal full of grace and activity. So we see that breeds probably gradually developed in certain localities, and that different causes helped to bring about the final result. There are many breeds of horses and ponies in different parts of the world. The following, however, are the only onescommon in America, that should especially interest us.

The Arab horse originated in the desert region of northern Africa, where he has been known sinee long before the time of Christ. The Arab is a saddle horse, but usually is a pony in size. The horses from Arabia and the Orient have had a great deal to do with the improvement of the horse in Europe. Between 1700 and 1800, many Oriental horses were taken to England. Their blood was mingled with the horses of that country, and especially with the race horse type, by which a great improvement in form and speed was seeured. Arab horses should be from 14 to $14 \frac{1}{2}$ hands high, have beautiful, intelligent heads; backs especially suited to the saddle; 
and have strong, muscular quarters and legs. The pure Arabian may be gray, white, bay, chestnut, or black. He is not of special value in America. He was first brought here about 150 years ago, though but few pure-bred ones are here now. The white or spotted horses often seen with circuses, are rarely pure-bred, and perhaps come from Turkey, Barbary, or elsewhere in the Orient, or have been foaled in America.

The Thoroughbred horse is of British breeding. In early days in England the horse was used largely for war. He had to be strong, in order to carry men who wore heavy coats of mail. After armor became unpopular, the people began to make more use of horses for other purposes. King James the First, at the beginning of the 17th century, established the race track, and since then horse racing has been very popular in that country and in France. It was then that the development of the Thoroughbred began. The people wanted a race horse. They took their native light horses that showed speed and improved them by the use of Arab, Turk, and other racing blood imported from Africa, Turkey, and France. The people became much interested in breeding these running horses, and as a result, developed the Thoroughbred into the fastest and best-bred horse in the world. Three imported Oriental horses, the Darley Arabian, the Byerly Turk, and the Godolphin Barb played a most important part in improving the early race-horse stock in England. Descended from these were three English-bred horses, Herod, Eclipse, and Matchem, that are very famous ancestors of modern Thoroughbreds. This breed of horses has a fine, lean, medium-sized head; a long, slender, neck; a narrow, deep chest; a long, sloping shoulder; a short, strong back; very long, muscular hind parts; and legs that are short, lean, and strong, with the best of fect. The skin is thin, and 
the hair fine and silky. The most desired height is 15 to $151 / 2$ hands, and the most common eolors are bay, brown, chestnut, or black, though there are other colors. A fine disposition and great courage are features of this noted breed. The Thoroughbred was first brought to America in 1730, and since then until recently, large numbers have been imported. This horse is raced under the saddle with a man called a jockey on his back. The fastest record of a race of any sort was made by Salvator, who in New Jersey in 1890

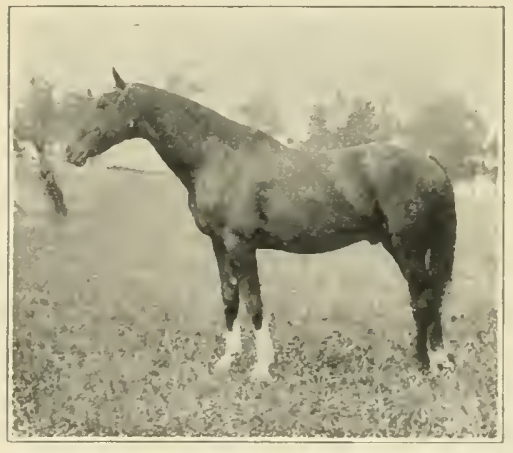

Fig. 8. Hanover, a famous Thoroughbred sire. Photograph by the author.

ran a mile in $1: 351 / 2$. Thoroughbreds have sold for enormous sums, Flying Fox having brought the highest price ever paid for a horse, of $\$ 187,500$. The Thoroughbred has been much bred in America in the past to improve our racing stock, but at present he is little used, except in running races where gambling is encouraged. As betting at horse races is a violation of the law in most states today, this has done much to discourage the breeding of Thoroughbreds in America. In England and France, eonditions are different. This breed has had a great history, and it is unfortunate that it camnot be popular in America, except as connected with gambling.

The American Saddle Horse is a brecl that has developed in the United States, especially in Virginia, Kentucky, Tennessee, and Missouri. Its ancestry comes with the mingling of the blood of the Thoroughbred and well made, easy- 
moving, native saddle stock. A Thoroughbred horse named Denmark, sired by an imported horse, was one of the most famous early sires of this breed. The American Saddle Horse shows much style in earriage of head and arch of neck and tail. He stands from 15 to $15 \frac{1}{2}$ hands high, and often

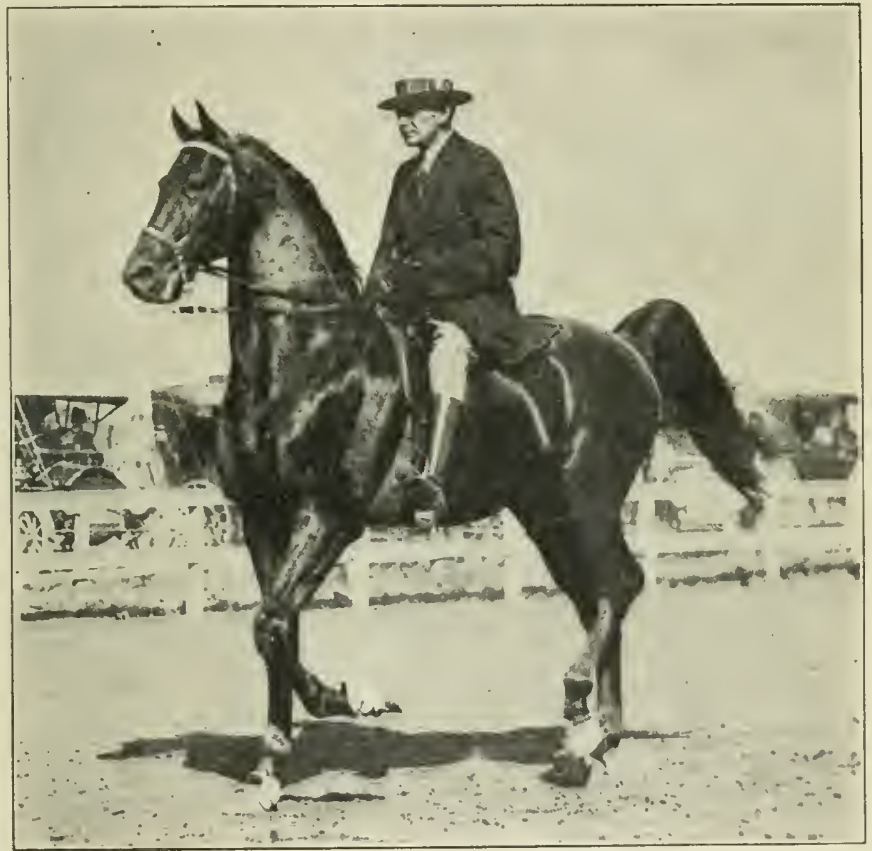

Fig. 9. Kentucky's Choice, a model American Saddle Horse. Photograph by courtesy th. National stockman and Farmer.

weighs about 1000 pounds. His most frequent colors are bay, brown, or black. This breed of horses is growing more and more into favor on account of its extremely easy gait. Saddlers may be divided into two classes. One has 
the walk-trot-canter gaits common with all saddle horses. The other class has five gaits, the walk-trot-canter, the rack, and the running walk or fox trot, gaits especially found with this breed. If a horse can show these five gaits, he is called a gaited horse. If he has only the first three, he is known as plain gaited. American saddle horses are in great demand, and when of high class, and educated to show their gaits well, bring high prices.

The American Trotter or Pacer has its parentage dating from the light-weight trotting and running horses of Great Britain first brought to America. One of these, a Thoroughbred named Messenger, imported in 1788, through his greatgrandson, Hambletonian 10, did much for trotting blood. For many years we have had in this country a class of horses of the light harness type, that are commonly known as trotters. They were so called because, when they moved faster than a walk, their gait was a trot, a movement of the front foot on one side and the hind foot on the opposite side at about the same time. The pacer moves back or forward at the same time, the feet on the same side of the body. The pace is about three seconds faster as a gait than the trot. Occasionally a horse may be taught to trot or pace as desired. Some famous race horses have both trotting and pacing records. The trotter or pacer is not a true example of a breed, because he has been mixed so much in the past in this country with all kinds of blood ancestry. The prineipal idea seems to have been to get speed. Trotters of this sort are often referred to as "Standard Bred." That means that they have official records of 2:30 (2 minutes, 30 seconds), or better, or are from stock registered in the American 'Trotting Register. A nice type of trotter or pacer should weigh around 1000 pounds, and have a lean, intelligent head; a refined and graceful neck; sloping, well laid 
shoulders; be narrow on top over the shoulders; have a strong, tairly level back; a muscular rump with tail set high; a deep, round body; and legs short, clean, and fine boned and good feet. This horse picks up his feet with snap, and moves off smoothly and easily. The coat is of different colors, with bay or brown most common. The disposition is generally good, though it naturally varies. This American-bred horse is the fastest trotter in the world. Uhlan holds the world's trotting record for the mile, in the time of $1: 58$ (one minute, 58 seconds); and Dan Patch the pacing record of $1: 551 / 4$ for the same distance. During 100 years, from August 25, 1810, when a horse named Boston trotted a mile in $2: 481 / 2$, to October 9, 1912, when Uhlan trotted a mile in 1:58, the mile trotting record was reduced 50 seconds, or an average of about one-half

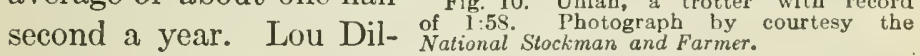
lon, a beautiful little

mare, long held the trotting record in a race against time, making a mile, in 1903, in $1: 581 / 2$. This record, however, was made with the aid of a shield to keep the wind from affecting her speed. There are many kinds of records, as half-mile, mile, two-mile, fastest new performer, fastest mare, etc. Thousands of horses have trotted a mile in $2: 30$, or better, and many even as fast as 2:10.

There are a number of famous trotting and pacing families, of which the Hambletonian, Mambrino, Clay, Pilot, 
and Morgan are the best known. Among the most famous trotters that have lived in recent years are the following: Maud S. 2:083/4, Nancy Hanks 2:04, Cresceus 2:021/4, The Harvester 2:01, Lou Dillon 1:581/2, and Uhlan 1:58. Among pacers are Hal Pointer 2:051/4, Star Pointer 1:591/4, Minor Heir 1:59, and Dan Patch 1:551/4. Trotters and pacers have sold for very high prices. Arion, the trotter, sold

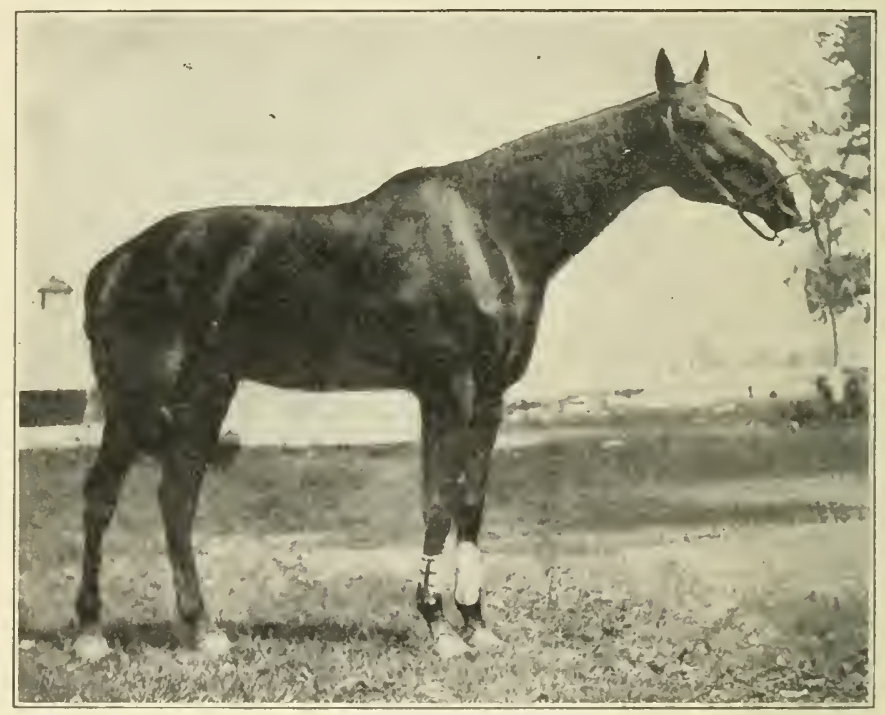

Fig. 11. Angus Pointer, a 2:00 pacer. Photograph by the author.

for $\$ 150,000$, and Dan Patch, the pacer, was purchased for $\$ 60,000$. Trotting and pacing horses have no great value outsicle of purposes for which horses of light weight ean be used, such as driving, racing, and in certain kinds of business where no special diraft power is required. Our people would be much better off today if we raised but a limited number of 
horses of this kind which we often eall roadsters, and only the higher grades of these.

The Hackney horse is a breed that was first produced in eastern England, especially in Suffolk and Norfolk counties. In these regions the trotting gait has long been popular. 'The word Hackney means "nag," and the term has been used?

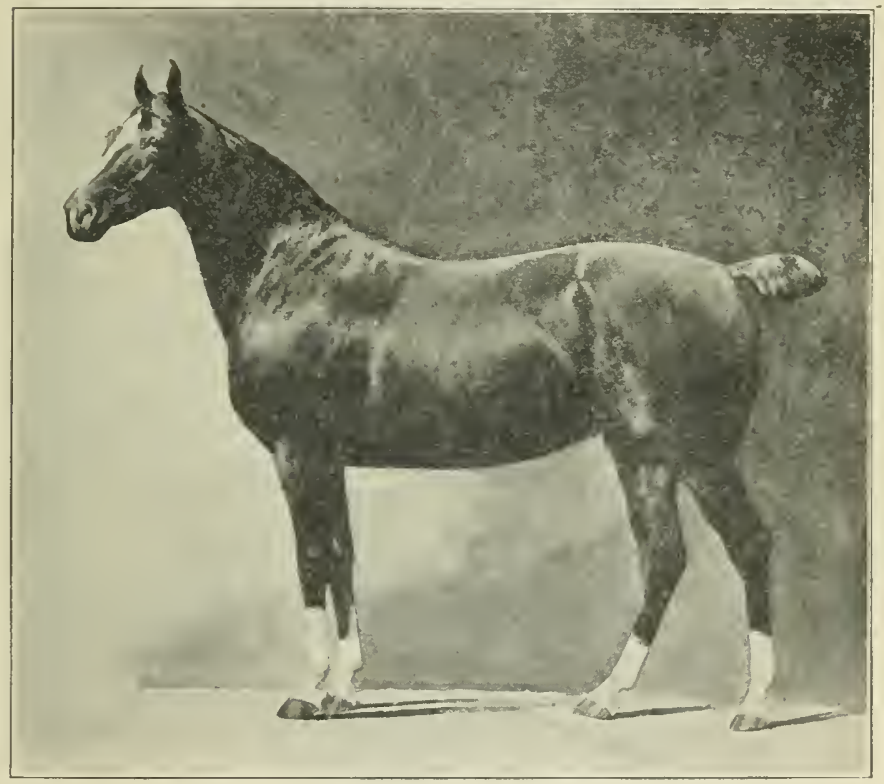

Fig. 12. Kathleen, a model Hackney mare, Photograph by courtesy F. C Stevens.

there for centuries. The claim is made that this breed began important development about 1755, with a horse called Shales. He traced back to the Darley Arabian, to which the Thoroughbred is related. The Hackney is very common in England, but not in Ameriea. It is a breed that varies quite 
a good deal in size, ranging from a pony to a good-sized carriage horse. When of suitable size, standing about 16 hands high, it is what is known as a heavy harness or carriage horse. A Hackney of good type, is very attractive of head, has a long, arehing neck, a fuller chest than a trotter, is strong and short of back, has a long, full rounded hind quarter; a beautiful round, smooth body, and stands squarely

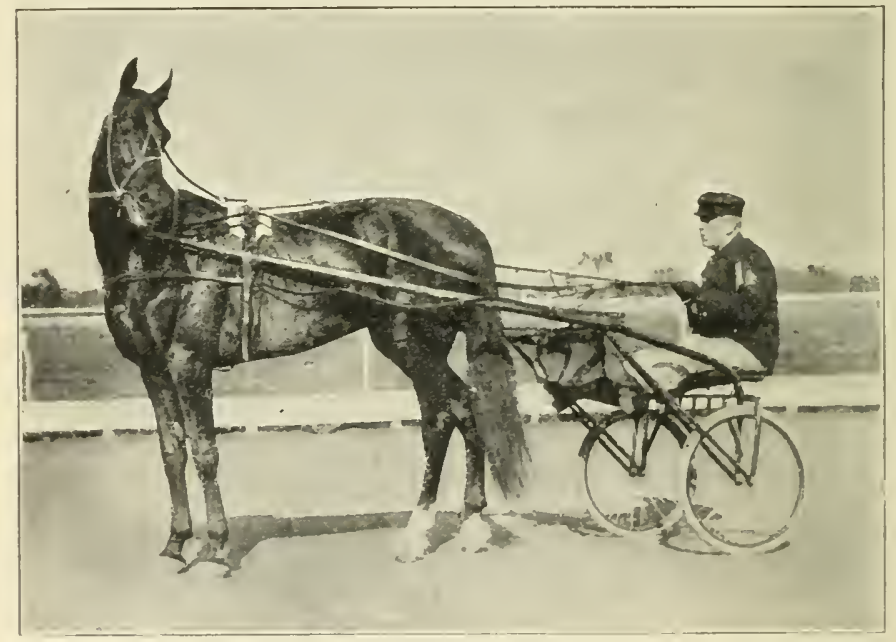

Fig. 13. The Harvester, the noted trotter, with Ed. Geers, his very famous trainer, in the sulky. Photograph by the author.

on short, clean-eut legs and good feet. Chestnut is a very popular color, as is bay and brown. This horse is noted for the powerful manner in which he moves the legs in the trot. He has a bold stride, lifting the knees higher than does any other breed, and earrying the hind legs forward with distinet power. The Hackney gait is a model in the opinion of many lovers of high-class carriage horses. If he is what is 
termed a high actor, that is, moves his knees up high rather than far forward, he will have a short stride which is somewhat slow, and is termed a "trappy gait." The Hackney in his native land is rather noted as a horse with considerable speed, and most excellent records have been made in driving over country roads. This is the most popular breed in the stables of wealthy men who keep fine carriage teams, but in recent years the automobile has greatly injured the business of breeding such horses. The Hackney has been extensively distributed over Europe, North and South America and Australia.

The French Coach horse originated in France. The people of that country have for centuries shown much interest in horse breeding. The famous Napoleon, over a hundred years ago, took an active interest in developing high-class horses. The people of France are great lovers

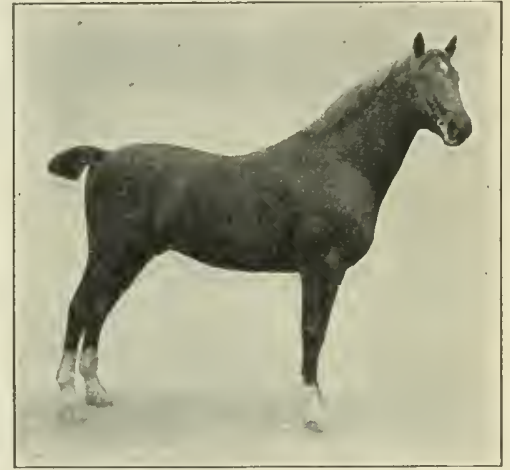

Fig. 14. Decorateur, a French Coach stallion, imported by McLaughlin Bros. of Ohio. Photograph by E. H. Mickle. of racing, and this breed came into prominence for that purpose. Some of the speed of the French Coach is inherited from the Thoroughbred and Hackney, many of which have been taken from England to France. The French government encouraged the people to breed these horses, partly for the army, and partly to give France a valuable carriage horse. The French government has extensive stables of valuable horses, and has produced in these many very fine animals. French Coach horses are usually bay, brown, or 
chestnut, though there are other colors. These horses are much like the other typical carriage horses in style and appearance, and do not have quite so trappy a gait as the Hackney. There are very few pure-bred horses of the French Coach breed in America, although they have been imported for many years. Probably more have been brought to Ohio and Illinois than elsewhere.

The German Coach horse comes from northwest Germany. In this region the breed has been kept for centuries. The government takes an interest in the improvement of the horse, in much the same way as in France. The German Coach horse is somewhat larger than the other carriage breeds of horses, and lacks the speed and action of either the Hackney or French Coach. These horses are usually bay, black, or brown in color, and stand from 16 to $16 \frac{1}{2}$ hands high. Not many horses of this breed are being brought to America today. Men who formerly bought carriage horses for driving, now use automobiles instead.

The Percheron horse is also of French origin. There is a small section of France called La Perche, which is about 100 miles southwest of Paris. It is a beautiful, rolling country, where the farmers have fine water, sweet grass, and fertile fields. In this region the Percheron originated. The breed is probably about 100 years old, but it has passed through important changes cluring that time. Fifty years ago Percherons were not as big as now, and they could trot quite fast along the highways. The demands of Americans during the past 2.5 years have caused the French to develop a larger size in these horses. It is now the most popular draft breed in America. Mature stallions weigh from 1700 to 2000 pounds, and mature mares from 1500 to 1800 pounds. The height is from 16 to 17 hands. The color is usually either gray of some shade, or black, though bay or brown 
oceurs occasionally. These horses are very massive appearing, when of the best type, having big bodies, strong wide backs, powerful hind quarters, muscular legs, and splendid feet. The legs are free from long hairs, this being one of the smooth-legged breeds. The Pereheron foot is especially shapely, of fine texture and proper size. Good specimens of

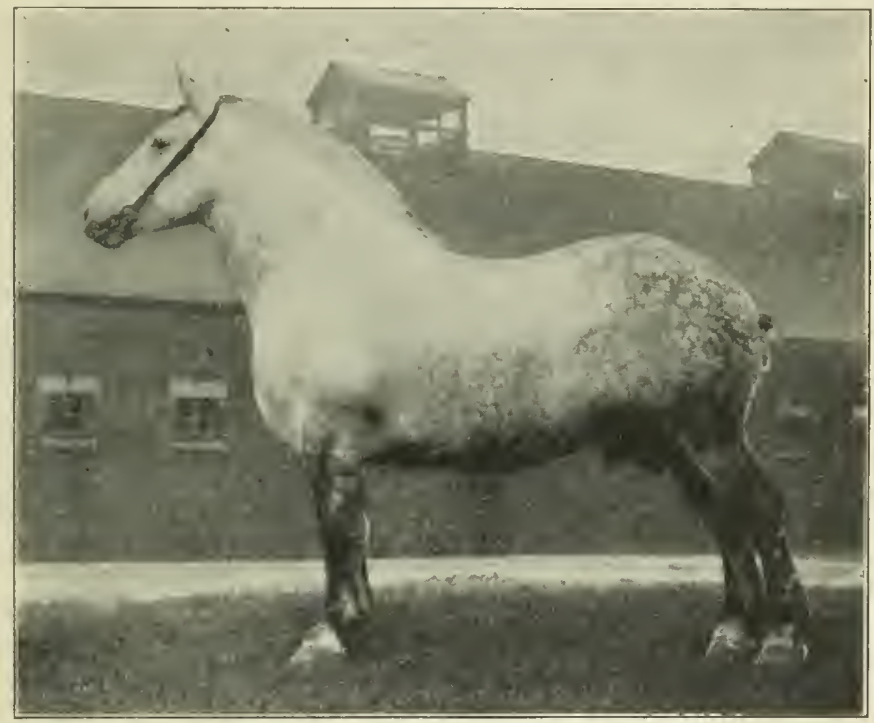

Fig. 15. Hautbois (7ł026), a splendid type of Pereheron stallion. First prize in 1911 at International Live Stock Exposition. Imported by McLaughlin Bros. Photograph by the author.

the Percheron have a very active gait and move off well with a load. We have no other draft breed in America that begins to have as many representatives as does this. Most of the draft horses seen in this country are largely of Percheron breeding. 
The first French draft horses of importance brought to America came to Ohio in 1851. A horse named Louis Napoleon, that was later taken to Illinois, became famous for his fine colts. Since then, up to the present time, many draft horses have been brought from France to America, and especially to the states of the corn belt north of the Ohio River. Very high prices have been paid for these horses, and in 1909, one of them, Carnot, a noted prize winner in

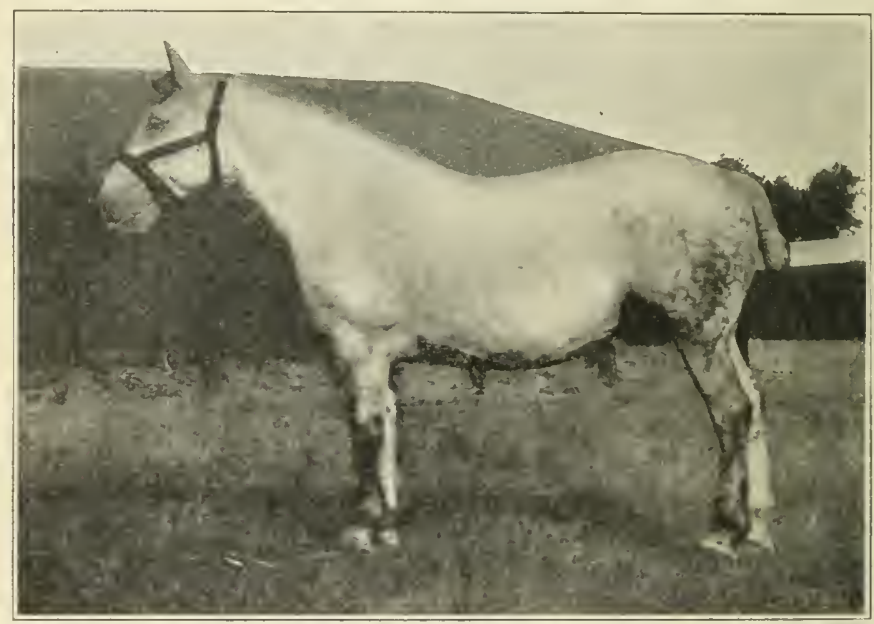

Fig. 16. Theresa (49283), a Percheron mare. Photograph by the author at Show of Pereheron Soeiety of Franee, 190S.

France and America, sold for $\$ 10,000$. Many work horses with considerable Percheron blood have sold for from $\$ 400$ to \$500. In 1900 such a work horse, weighing 1910 pounds, sold at auction in St. Louis for \$730. A real high-class matched team of this kind, woighing around 3500 to 3600 pounds, will bring a big price in the market. 
The Clydesdale horse is a breed that was developed in southwestern Seotland, where it has been known since about 1715. The Clydesdale is not quite so large as the largest draft breeds. It has certain features that perhaps are notable. To begin with the feet, they must be large, round, and wide behind at the heel, with a good, elastic frog. The bones of the legs should be hard and not round and meaty, but the arms and quarters must be heavily museled. The

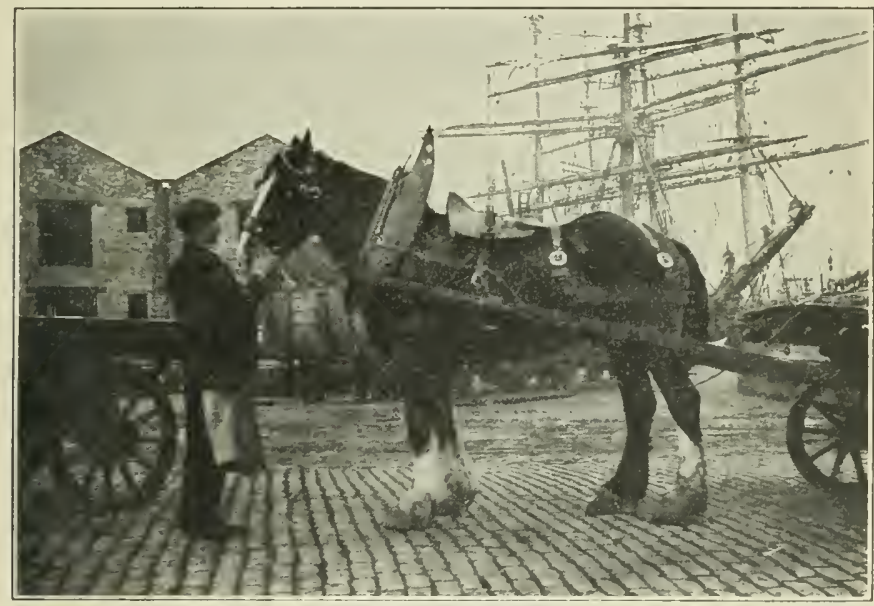

Fig. 17. A Clydesdale horse at work on a street in Scotland. Photograph by the author.

Scotchman thinks his horse has the best of feet and legs, and when either walking or trotting, that he has the best movement of any draft horse. It is a fact that many Clydesdale horses move with splendid action, and carry their feet with snap and trueness. This is a hairy-legged breed, with long hair on the back of both front and hind legs from the knee and the hock down. The body of the Clydesdale often lacks 
massiveness, so that these horses appear shallow of body and long of leg. This is the prineipal criticism of this breed today. The shoulders usually slope well into the back, which accounts for the easy movement of this horse. The color is usually bay or brown, with white markings on the face and on the lower part of the legs. There are also chestnut, black, and grays occasionally to be found. The height is about $161 / 2$ hands for the matured males. Typical Clydesdale mares weigh from 1600 to 1700 pounds, and the males two or three hundred pounds more.

Clydesdales were first brought to America in 1812, being taken to Canada, where they are quite common today. The breed has a wide distribution in the United States, though not in large numbers in any one state. Wherever the Scotch farmer has settled, we are likely to find these horses. The stallion Baron o'Buchlyvie in 1911 sold for $\$ 47,500$.

The Shire horse is an English breed of much the same general character as the Clydesdale. It has been bred for many years in England, and is as popular with the Englishman as the Clydesdale is with the Scotchman. These horses differ in certain important respects, though they have the same color and markings, as a rule, and both have the hairy legs. The Shire is a somewhat larger and more massive breed than the Clydesdale, and has a wider back and deeper, heavier body. For many years the Shire was considered very slow in movement, and lacked good action and quality. In recent years, English breeders have done much to improve them, and the eriticisms of slow movement and coarseness are not as correct as they once were. The eriticism due to the hairy legs is still made, and this breed, like the Clydesdale, is not at all common in Ameriea. These horses have been brought to America in small numbers since about 1836 , when one was brought to Canada. Perhaps more of 
these horses are in Illinois and Iowa than in any of the other states. In 1910 a Shire stallion named Dan Patch sold at Chicago for $\$ 10,000$.

The Belgian horse comes from one of the smallest countries in Europe. Belgium has done much to improve the

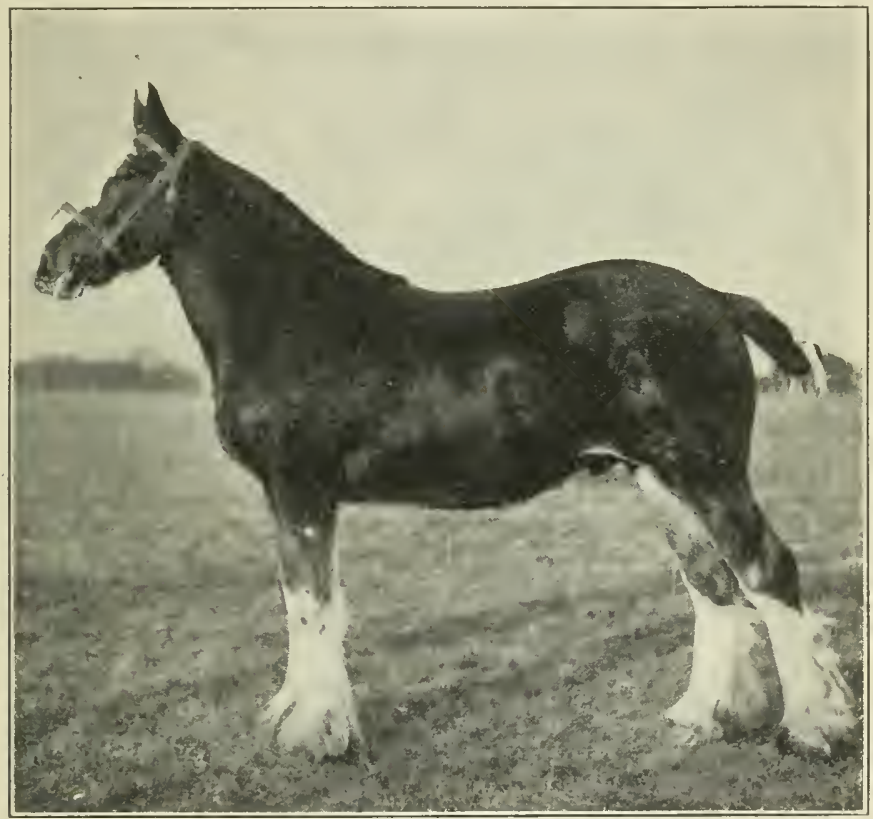

Fig. 1s. Rosco V (12551), a yearling Shire horse, owned by lllinois University. Photograph by courtesy Prof. J. L. Edmonds.

draft horse, and the Government has paid out large sums of money to develop the breed. The people take much interest in the work, and the draft horse shows of this breed alone at Brussels are among the very greatest exhibitions in Europe. Draft horses have been bred in Belgium a very long time, but 
they have been most improved sinee about 1850. The Belgian is a very compact, wide, deep, short-legged sort of draft horse. He has a small head, perhaps, for his size; has a broad chest; very wide, short back; a deep body; a rump which may be quite wide and muscular, yet somewhat steep; very heavily muscled, short legs; and medium-sized feet which have been criticised sometimes as being too small for

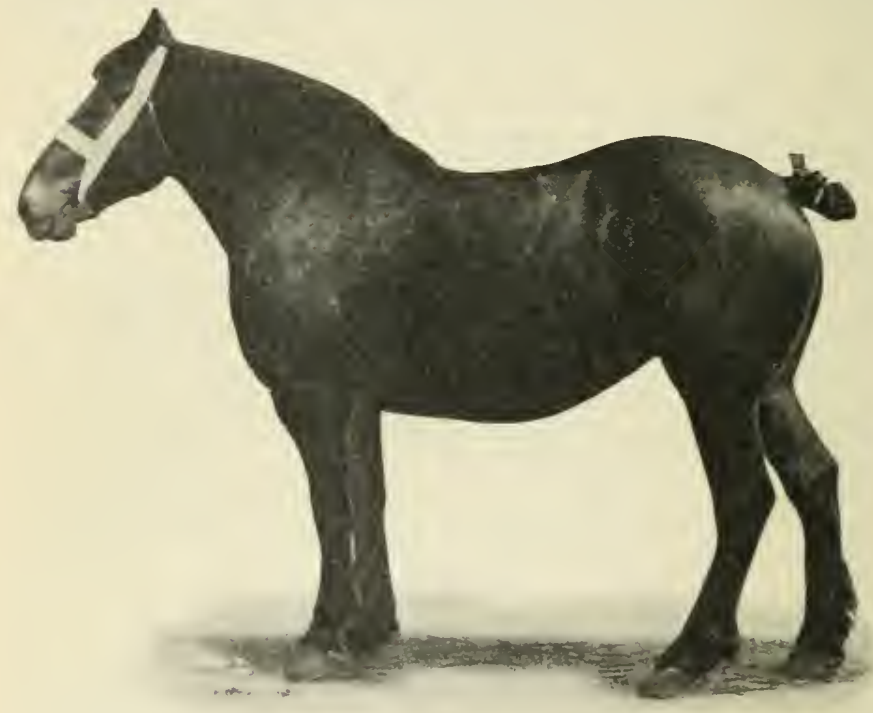

Fig. 19. A Belgian mare. Photograph by courtesy A. Van Schelle of Belgium.

such a heary horse. The legs are free from hair, like the Pereheron. The Belgians show considerable activity when in motion, and are powerful draft animals for their weight, which ranges from 1600 to 2000 pounds, usually, according to sex. They stand about 16 hands high. In disposition these horses are very gentle and can be easily handled. Their 
color is usually bay, brown, chestnut, or roan. These horses were first brought to America in 1866. In recent years, a great many Belgians have been imported, and the breed has grown much in favor, being second in this regard, probably, to the Percheron. It is getting quite a foothold in the Middlewestern states.

The Shetland pony has its native home on the Shetland Islands, about 200 miles north of Scotland. These are very rocky islands, and produce but little feed for live stock. The climate is very cold and rough, and the winters are most severe. There are about 120 islands, and Mainland is the largest. These ponies have been bred here perhaps for centuries. They vary quite a good deal in type. The best sort of Shetland stands from 36 to 42 inches high, and is a shaggy, drafty-looking little pony, especially in the winter. These ponies should really be miniature

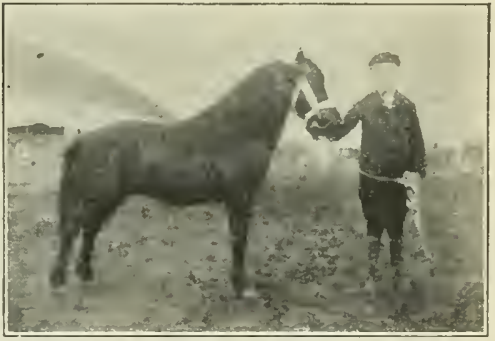

Fig. 20. A Shetland Pony. First prize at Glasgow. Photograph by the author. draft horses, with full chests, wide backs, long ribs, and long, wide, level rumps. The hearl should not be too fine, and should have a broad forehead, and a nice, open, clear eye, showing the pleasant disposition usual with ponies of this breed. There are different colors, but bay, brown, and black are most frequent. Shetland ponies are common all over eastern America, and are great favorites with children. They are very patient and are safe pets. In England, large numbers have been used in the coal mines to haul coal cars.

The Ass is commonly referred to in-America as the jack, this being the male, while the female is known as the 
jennet. This animal is descended from the mild ass of Africa and Asia. There are several breeds of the domestic ass, most of which were introduced to America from Spain. During the Revolutionary War, George Washington was presented with a male and female ass by the King of Spain. The jack usually stands about 15 hands high, and the jennets $141 / 2$. The hair is usually brown or black with a creamy shade around the muzzle or along the underside of the body. The ass has long, large ears, rather a large head

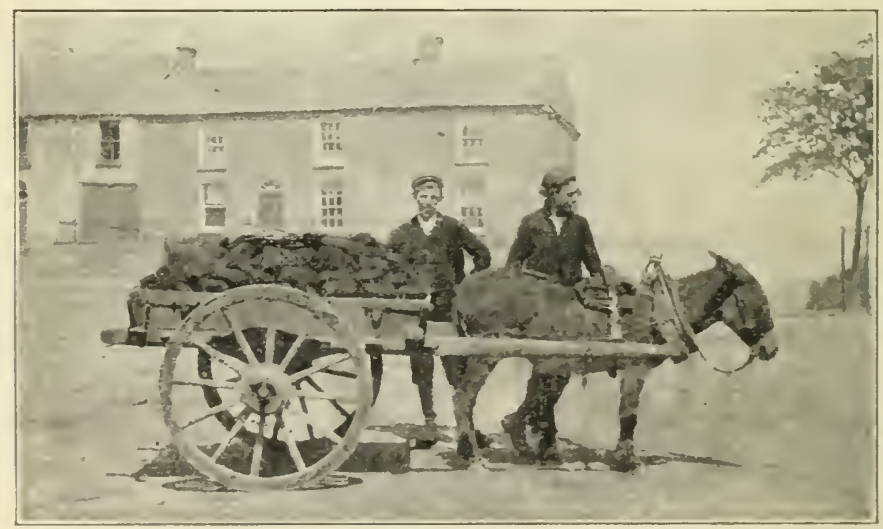

Fig. 21. A donkey and load of peat in 1reland. Photograph by the author. for the body, a short, stubby mane, a round but not very large body, rather large legs, and small feet. The tail is fine, with simply a brush at the end. This animal is slow of movement, very patient, and is a beast of burden used mostly among poor people of southern Europe and parts of Africa and Asia. In America it is but little used excepting for breeding.

The Mule is the offspring of an ass and mare. Mules differ much in size and value, and have features of both 
parents. The head, mane, tail, and feet resemble those of the ass. The mules also bray like the ass. Mules show more fineness of bone and more activity than the ass, and are used entirely for draft purposes. Large, strong heavy mules are worth more money than the small ones. The best mules resemble the high class draft horse in form. In the mule markets, these animals are classed according to their size and use, as plantation, lumber, railroad, mine, and levee mules. St. Louis is the largest mule market in America. The average price for mules is higher than that for horses. Mules are invaluable for draft purposes, and are commonly used all over the Southern states. They are more easily kept than horses, and possess more endurance and are always patient.

\section{QUESTIONS AND SUGGESTIONS}

1. What was the earliest form of the horse, and where was he found?

2. Give some of the conditions that influenced the development of breeds.

3. Why were Herod, Eclipse, and Matchem famous?

4. What is the difference between a trotter and a pacer?

5. Describe a Hackney horse and his gait.

6. What conditions promoted the coach horse in France?

7. Describe a modern Percheron.

8. In what respect does the Scotchman think the Clydesdale a superior horse?

9. How do the Clydesdale and Belgian differ in color?

10. Tell of the Shetland Islands and their ponies.

11. Describe the special features of the ass.

12. What breeds of horses are found in your neighborhood?

13. Learn, if possible, of the most important draft horse that has been known in your community. Why was he important?

14. Leam of the breeding, if any, of the saddle horses in use in your neighborhood.

15. Who owns the largest mule in your neighborhood? Can you give his height and weight? 


\section{CHAPTER III}

\section{THE BREEDS OF CATTLE}

The first early cattle of which we have any information existed in Europe in prehistoric times. The bones and skeletons of two very different types of eattle have been found in Great Britain and parts of Europe. One of these was very much larger than the cattle of today, and has been called the Giant Ox. The other is much smaller and finer of bone. The skeletons of these two forms are quite similar to the eattle of our own time. Many bones of these animals have been found, and it is believed that even in the stone and the bronze age the people had cattle more or less domesticated. Pliny and the earliest historians refer to swift and fierce wild bulls, called Uri, that were found in the forests and meadows of Germany and other parts of Europe at the beginning of the Christian era. The early Romans captured specimens of these wild bulls and took them to Rome and used them in their brutal festivities.

Wild White Cattle have been known in England, Scotland, and Wales since earliest historical times. These cattle lived in great parks. They had upright horns, were covered with shaggy hair, and were pure white in color, except the hair about the ears and muzzle, which was usually a dark red or black. A number of small herds of these cattle are kept today in Great Britain, one of which is at Chillingham Park in northeastern England. This herd numbers only 60 or 70 animals, which run wild on an immense estate. They have never been tamed, but live by themselves back among the hills in the forests and meadows. It is believed 
that these wild cattle are descended from the Giant $\mathrm{Ox}$, and are the connecting link between the prehistoric form and our domesticated cattle of the present time.

Shorthorn Cattle. This noted breed, commonly called Durham cattle years ago, originated in northeast England, in the counties of Durham and York. The river Tees flows through a pretty valley, and for some distance is the boundary line between these two counties. This region, many years ago, was called the Teeswater country, and the large cattle

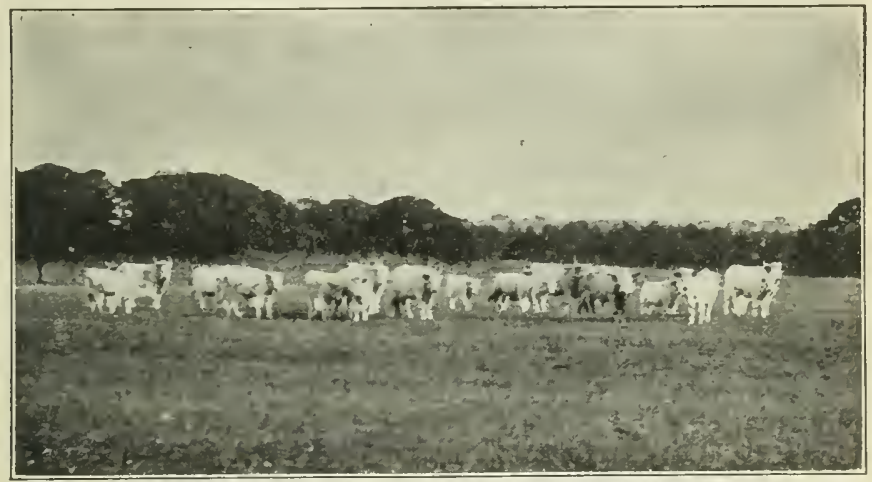

Fig. 22. A herd of Wild White Cattle at Vaynol Park, Wales. Photograph by the author.

found here in northern Yorkshire were known as "Teeswater Cattle." In southern Yorkshire, in what is called Holderness, was another kind of cattle having some things in common with the Teeswater. Many of these were black. There were also red or red-and-white cattle in other sections not far from here. Some cattle of superior milking qualities were brought over from Holland, also, in the middle of the 18th century. From these various sources came the Shorthorn. In this section of England the grazing was fine; and 
the city of Darlington, by the river Tees in Durham, became in time a great cattle market.

The improvement of the Shorthorn began over a century ago. Two brothers, Charles and Robert Colling, who lived on separate farms north of Darlington, did much to improve the native stock between 1775 and 1820. Some have called them the founders of the Shorthorn breed, though this is probably not correct. They developed their cattle so that

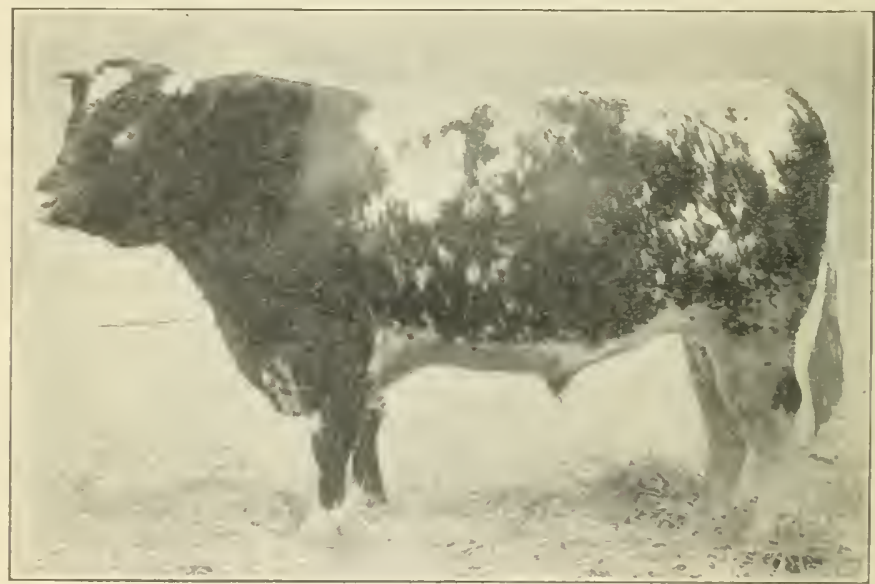

Fig. 23. Pingmaster, champion Shorthorn bull at the International Live Stock Exposition, 1911. Owned ly White and Smith of Minnesota. Photograph from The Farmer.

they matured carlier, forl better, and had less waste at slaughter than the eattle with which they began.

Thomas Bates lived in this same region, east of Darlington, and he hred a type of large, handsome eattle, noted for both beof and milk prorlustion. His cattle have been eriticised for lack of vigor. He producerl the Duchess, Waterloo, Wild Eyes, Oxford, and oflere families. Bates died in 1849. 
Thomas Booth, another great breeder, began to keep Shorthorns about 1780 on a farm southeast of Darlington, in Yorkshire. He had two sons, John and Richard, who also became famous breeders. Their eattle had thicker chests, were somewhat rougher in form, and perhaps better feeders than the Bates cattle, and became very popular. The Booths produced the Anna, Isabella, Bracelet, Moss Rose, and some other families. The Collings, Bates, and

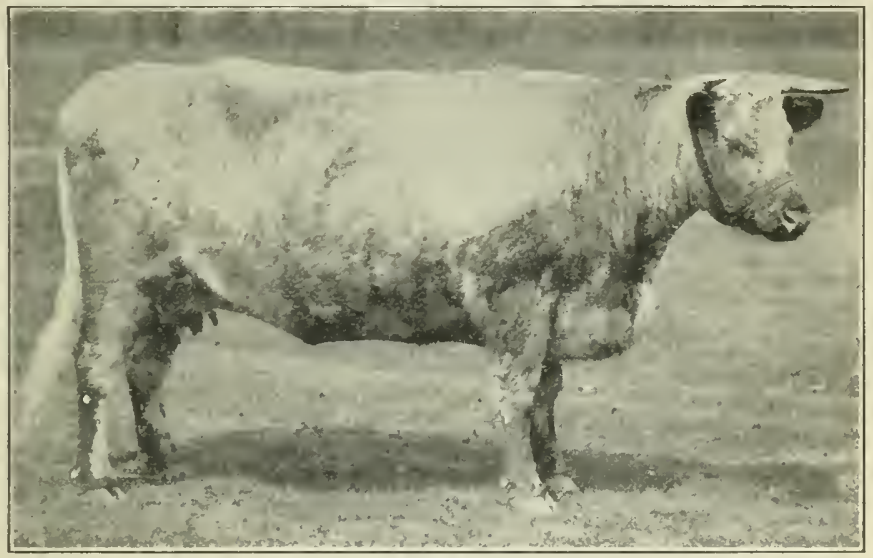

Fig. 24. Czarina 2nd. A thick fleshed type of Shorthorn cow. Owned by Ohio State University. Photograph by F. H. Haskett.

the Booths were famous as among the greatest improvers of Shorthorn cattle that have ever lived in England.

Up in Scotland, in Aberdeenshire, where the winters are cold and rough, and the soil not the richest, lived a quiet man by the name of Amos Cruickshank. He developed what are known today as "Scotch Shorthorns." They are noted for their early maturity, compact forms, strong constitutions, and fine killing qualities. Scotch cattle seemed to produce 
less milk than those bred by Bates, but were thicker fleshed, so that butchers liked them better. Cruickshank produced quite a number of the most popular families of today, among which the Violet, Venus, Orange Blossom, Brawith Bud, Spicy, and Lovely may be mentioned. Cruickshank died in 1895 . He is regarded as the greatest breeder of Shorthorns in the history of Scotland.

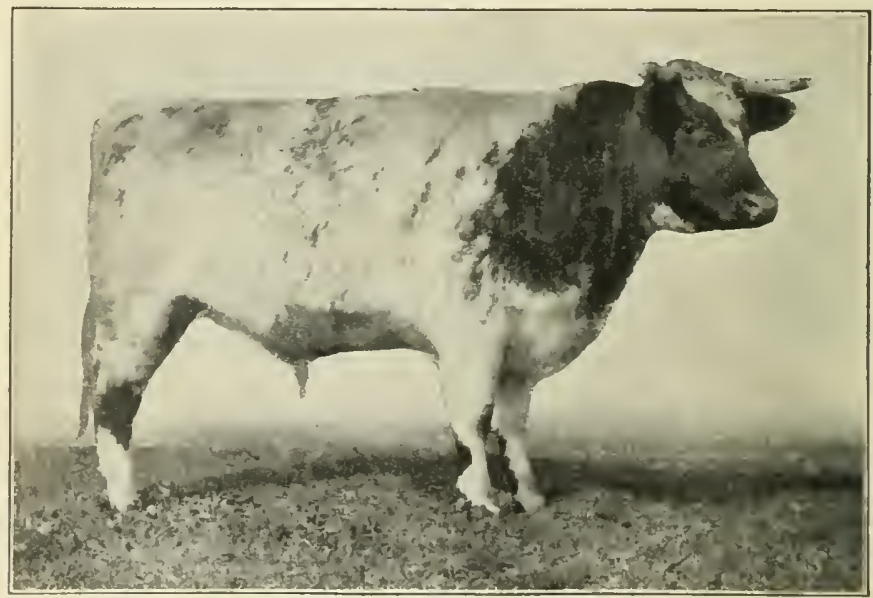

Fig. 25. A Shorthorn steer owned by the Ohio State University. Photograph by the author.

The distribution of Shorthorns is world-wide. It is the most common breed of English speaking countries, and more great improvers of live stock have been found among Shorthorn breeders than any other one breed. So common is the Shorthorn, and so well is it suited to different conditions, that long ago it was nicknamed "The Universal Intruder."

The introduction of the Shorthorn to America occurred in 1783 , when a few were imported into Virginia by Gough 
and Miller. These men imported still others about 1792 . From this time on the Shorthorn continued to be brought to the American states long the Atlantic coast. In 1834 a very important shipment came to Ohio, selected for the Ohio Importing Company. Since then many thousands of Shorthorns have been imported, and are found distributed widely in North and South America.

The Shorthorn characteristics are very distinct. The color is red, red-and-white, pure white, or a mingling of red and white forming what is called a roan. It is one of our largest breeds, and bulls at maturity should weigh around 2000 pounds, and the cows about 1400 pounds. These cattle have white, waxy-colored horns of medium size. The heads are very shapely, and the muzzle is preferably flesh color, dark noses not meeting with Fig. 26. A good type of milking Shorthorn. approval. They should

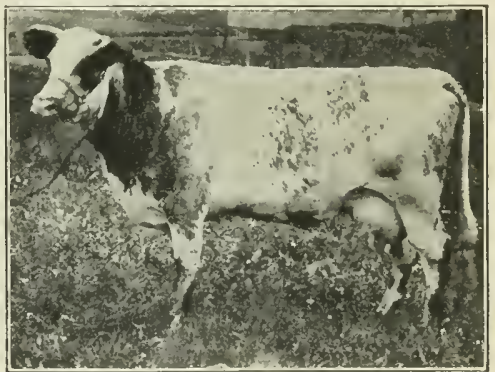
Photograph by courtesy The Farmer. have broad backs, large bodies and unusually well developed hind quarters. Shorthorns have been criticised for having plain shoulders and for being rather long of leg. In disposition, the Shorthorn is unexcelled. This is the largest nilkproducing breed of beef cattle, many cows yielding from 6000 to 7000 pounds of milk. Rose of Glenside, in one year made over 18,000 pounds of milk, containing 735 pounds of butter-fat,- - a wonderful record. Shorthorn milk usually contains almost 4 per cent butter-fat, and is of standard quality. Cattle of this breed fatten well, and produce a very high class beef. They are usually prominent 
at shows where cattle are exhibited. The future development of this breed will not be so great as in the past, perhaps, owing to the increased demand for special milk breeds; but from the beef standpoint, the Shorthorn may be expeeted to remain popular for a long time to come.

The Hereford breed of cattle originated in the county of Hereford, in southwest England. There are many beauti-

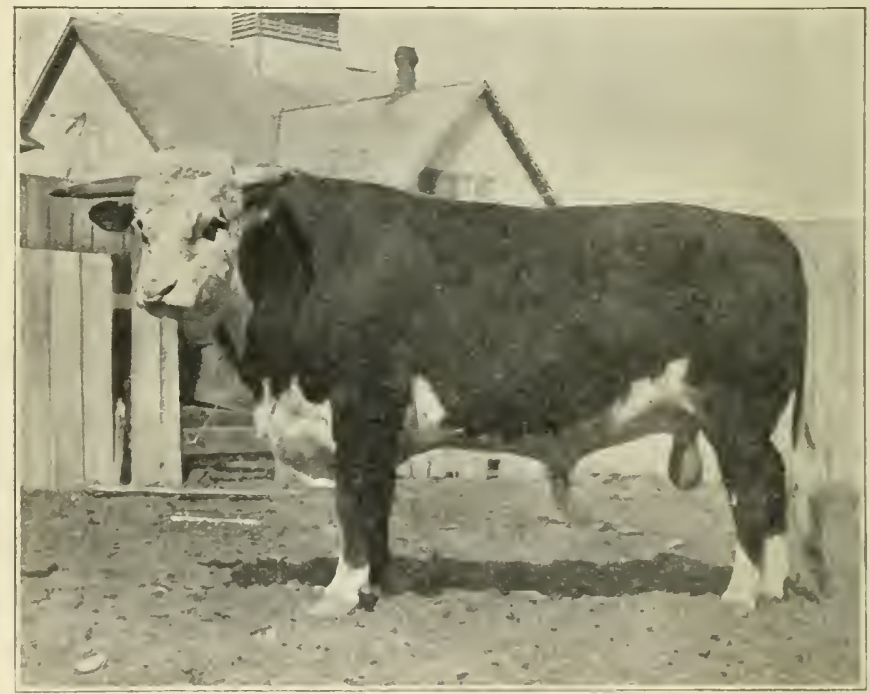

Fig. 27. Shadeland Leo, a Hereford bull owned by Purdue University. Photograph by the author.

ful meadows and grassy hills in this region. The cattle graze here the year round and are rarely kept under roof. We know but little of the origin of this breed. Cattle have thrived in this part of England for eenturies. One noted English judge of live stock over a hundred years ago, gave the opinion that the Hereford might have been the first breed 
on the island. Some time before 1671, white faced cattle were brought from Holland to Hereford, and some think the Herefords get their white faces from these eattle. Late in the eighteenth century, the common color of the breed was red with a white face. As with the Shorthorn, a number of men became noted Hereford improvers and did much for these cattle. The Tomkins family is the most famous of early days. There was Benjamin the Elder, who died in 1789 , and Benjamin the Younger, who died in 1815 . These men produced many famous animals and did much for the

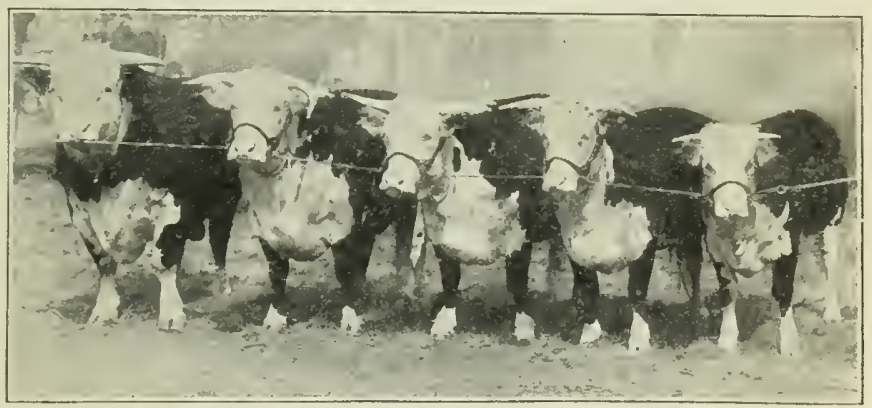

Fig. 28. An exhibitor's herd of Herefords at the fair. Photograph by courtsey The Farmer.

breed. William Galliers, John Price, and John Hewer also did much to improve the Hereford. John Hewer sought for more size, quality, and uniformity of color. He bred many famous animals during the middle of the last century. Herefords were first brought to America by that famous statesman, Henry Clay, of Kentucky. He took much interest in pure-bred live stock. Mr. W. H. Sotham, a native of Hereford, who emigrated to America in 1840, brought some of these cattle to Albany, New York. Mr. 
Sotham did much to make the breed popular in this country during the middle of the nineteenth century.

About 1875, men in Illinois, Indiana, and the West, who owned a great deal of land, became interested in the Hereford. Since then these cattle have become very popular in the grazing sections of the West, and are found in large numbers beyond the Mississippi. The Hereford is a large breed, carrying as much size and weight as the Shorthorn. The color is its most striking feature, the head being white,

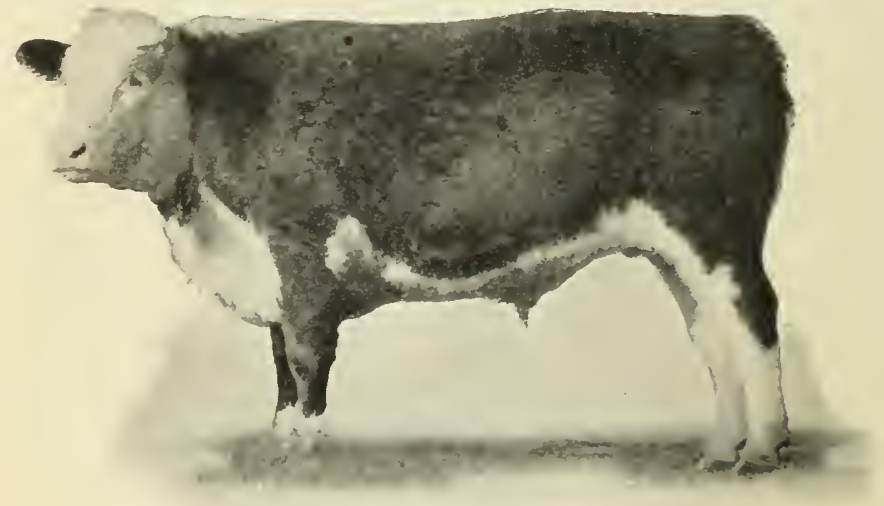

Fig. 29. Black's Ohio Champion, a grade Ilereford stecr, owned by Ohio State University. Photograph by the author.

as is often also the top of the neek, the breast, brush of the tail, and legs below the knees and hocks, the rest of the body being red. They are often called "White Faces." These cattle have widle backs, deep bodies, and short legs. They have beautiful smooth shoulders, but the hind quarters are liable to be somewhat narrow, lacking the fullness of the Shorthorn. 'They are noted feeders, and have no superiors as grazers, thriving well with the least shelter and grain. In disposition they are rather nervous as compared with the 
Shorthorn. They are inferior milkers, though producing a fair grade of milk. The quality of "rustling," as they say in the West, fine constitution, and ability to make early beef, has made the breed extremely popular in the far West. These cattle are also popular in South America and Aus-

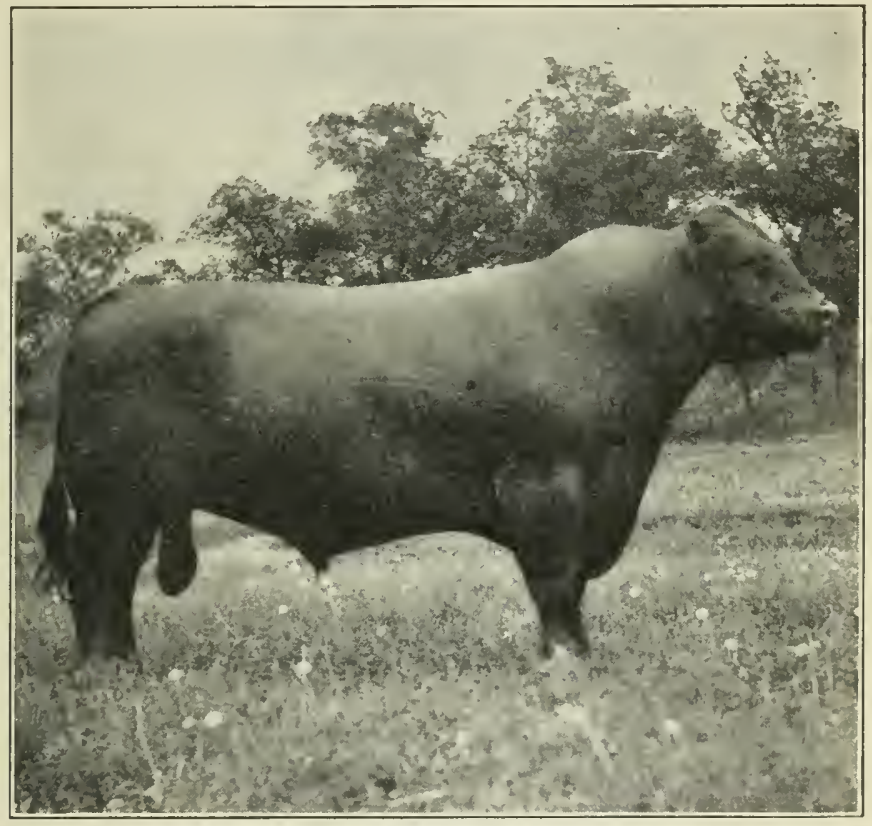

Fig. 30. Lucy's Prince 46I83, a famous prize-winning Aberdeen Angus bull and sire, owned by Bradfute \& Son, of Ohio. Photograph by the author.

tralia, on account of requiring but little attention on the range. In our fat-stock shows, Herefords have made good records, for they produce excellent beef and kill out well.

The Aberdeen Angus is a Scoteh breed of cattle that was first developed in and about the county of Aberdeen, in 
northeast Scotland. 'This section is about a thousand miles north of the latitude of Chicago. The winter climate of this region is rather severe, and the soil is not the best, though the grazing is good. Somc think these animals are descended from the Wild White Cattle. It is a hornless breed. They first became celebrated through Hugh Watson, a tenant farmer at Keillor. He loved his cattle and studied carefully the improvement of his herd. As a result he produced more early maturing, heavier fleshed, and more compact cattle

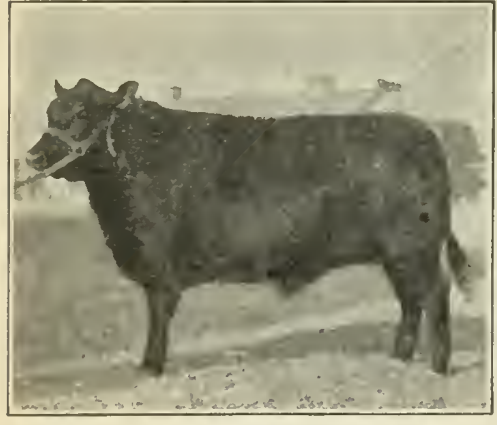

Fig. 31. Foxy, 2nd prize Aberdeen Angus stcer at International Live Stork Exposition. Shown by Ohio State University. Photograph by author. than had before been known in Scotland. He had a cow named "Old Grannie" that lived to be 36 years old, and was the mother of 25 calves, a wonderful record for a cow of any breed. William MeCombic was another famous breeder of Aberdeen Angus cattle. He improved on the work of Watson, and his cattle became celcbrated for the prizes they won in the shows of Scotland and France. Sir George McPherson Grant, who died in 1907, was the most noted breeder of recent days, and from his herd came some of the greatest eattle of the breed.

The first Aberdeen Angus cattle were imported to America in 1873, by George Cirant, of Kansas. Later in the seventies a few head were taken to Canada, Now York, Illinois and other states of the central West. It is only in rather recent years that these cittle have become popular in Amorica. Aberderen Angus are black in color, though 
oceasionally red will oceur. They are inclined to be a trifle prominent in the shoulder, having only moderately wide backs, the loin not being so broad as that of the Shorthorn or Hereford. The hind quarters usually are rather round and full, though the tail-head may be a bit prominent. These cattle stand on short legs, and are very compact. They graze well, mature very early, fatten smoothly, produce meat of the choicest grade, and kill out with the least waste possible. In the fat-stock shows in recent years, no other breed has won so many grand championships. At our great International Live Stock Exposition at Chicago, the Aberdeen Angus has won a very large pereentage of the most important prizes where breeds competed against one another. In slaughter tests they have dressed out 72 per cent carcass to offal, which is a very high record. Some of the cows are good milkers and produce an excellent grade of

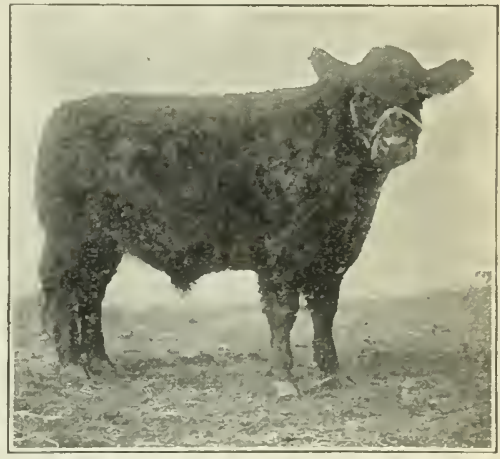

Fig. 32. A Galloway steer. Photograph by the author.

milk. In disposition, they are nervous and are more like the Hereford than Shorthorn. Aberdeen Angus cattle are not extensively bred east of the Mississippi, and do not seem to gain in popularity there, any more than does the Hereford. Iowa contains more important herds than any other state.

The Galloway is a beef breed that originated in southwest Scotland in what is known as the Galloway country. It is a hilly region, with plenty of grass, and has a somewhat cool and rather moist climate. These cattle have been bred 
here for centuries. They are black, though other colors formerly occurred, are polled, have long, shaggy coats of hair, and are hardy and rather wild by nature. They are not quite as large nor so compact of borly as the Aberdeen Angus, and do not fatten so easily. They produce a very high grade of beef, fine of grain and inclined to be free from extra fat, such as is often found in highly fed Shorthorns or Herefords. The Galloway is a breed that can endure severe winter conditions better than most others, on account of the protection of a thick hide and a long, thick, silky coat of hair. Very beautiful robes are made from Galloway hides with the winter coat of hair. This breed was first brought to America about 1850 , or perhaps some years before. It is not popular and the herds are rather scattered, more being in the northwestern states and in Canada than elsewhere. The exhibit of the breed at the fat-stock shows and fairs is usually small compared with the Shorthorn, Hereford, and Aberdeen Angus.

The Jersey is strictly a dairy breed of cattle that originated on the island of Jersey. There is a small group of what is known as the Channel Islands lying in the English Channel, not far from the Normandy coast of France. Jersey contains about 40,000 acres, Guernsey about 12,000, and Alderney very much less. The climate here is quite mild and balmy much of the year. The cattle live out of doors during a very long scason, each one grazing tethered by a chain and rope fastened to an iron pin in the ground. The herds are small, and these and potatoes are the chicf sources of income on Jersey. There are perhaps 12,000 head on the island.

Jersey cattle are supposed to have originated from stock in the neighboring distriets of France. They have been kept pure of blood for much over a century. As early as 1763 
the people on the island adopted laws to regulate the importation of cattle from France. For a very long time no foreign cattle have been allowed to enter Jersey, except such as were butchered within 24 hours after landing. In 1833 the people organized a society to improve the agriculture of the island, and the next year they drew up a scale of points for the bulls and cows. This was the first scale of points marle for a breed of live stock. Since then it has been

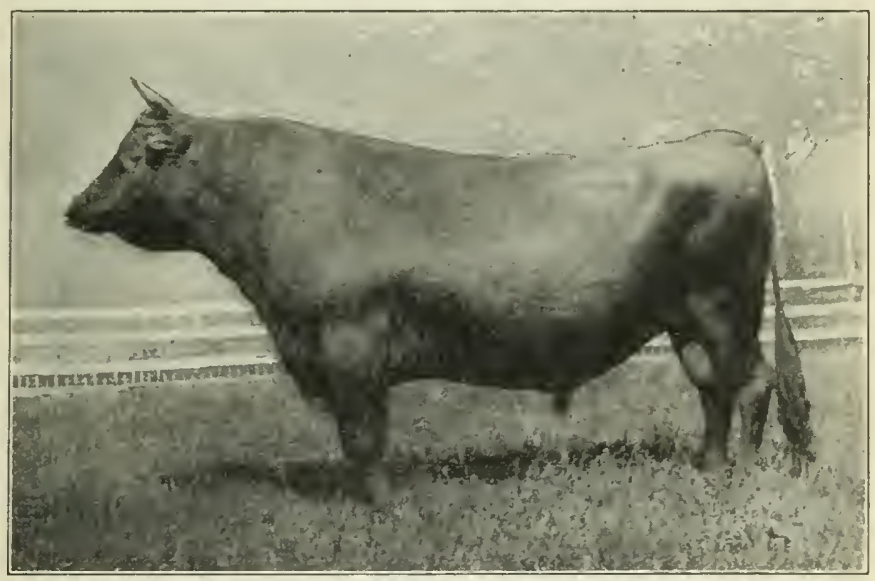

Fig. 33. Raleigh's Fairy Boy 83767, an imported Jersey bull, champion of the breed at National Dairy Show and elsewhere, 1910. Owned by C. I. Hudson, of New York State. Photograph by the author.

changed and improved a number of times. The people made notable progress in improving their cattle, and no doubt the competition of the show ring and the butter and milk tests which were established, inspired them to study to secure this improvement.

The Jersey was first brought to America about 1850, Connecticut and Massachusetts men being the importers. Since then large numbers have been brought to this country, 
and have been widely distributed over the United States and Canada, so that now this is the most eommon dairy breed of cattle knomin.

The Jersey is of medium size, though many seem small. Mature bulls should weigh around 1300 pounds, and the cows 850 pounds. These cattle are rather lean and angular in form, having attractive heads, medium long necks, thin withers, prominent shoulders, fairly deep bodies, and thin, narrow hind quarters. The thighs should be thin enough and the hocks stand far enough apart to provide room for a good sized udder on mature cows. The modern so-called island type of Jersey has a beautiful udder, well developed in front, with the teats well placed. Many Jerseys of American breeding have poor front udders, and they are criticised for having small and poorly placed teats. The color is fawn, but of various shades, some being the eolor of the deer, others very dark and some mueh lighter yellow. White occurs, though it is not popular, and but few animals have white markings. The most striking features in the appearanee of the Jersey are the color; the wedge form; the short, dished face; the prominent, beautiful eye; the fine bone, and the deer-like character of the calves. The disposition of the cows is very good, but the bulls at maturity are liable to be nervous and are often cross. Jerseys mature very young, compared with other breeds.

The Jerseys have always been noted for their milk, which is rich in butter-fat, and is usually ycllow in eolor. The skin of these cattle show something of this rich yellow color, especially in the small, wax-colored homs, in the ears, and about the udder. The Jersey produces a fair amount of milk, and many eows have made over 5000 pounds a year each. Quite a number have produced over 10,000 pounds, and Jacoba Irene produced over 17,000 pounds in a year. 
Jersey milk usually contains $4 \frac{1}{2}$ to 5 per cent of fat, and makes a high grade of butter. Many cows have produced enough milk in a week to yield 14 or more pounds of butter. A number have records of over 20 pounds in a week. Many Jerseys have produced enough milk within a year to yield 500 pounds of butter, and some have even exceeded this.

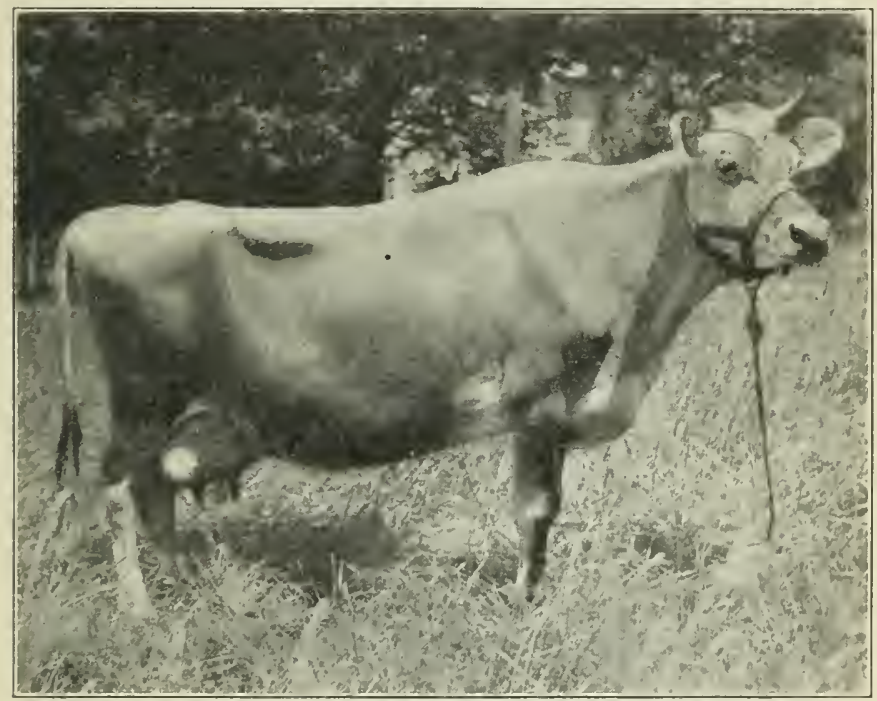

Fig. 34. Golden Sultana, a very beautiful Jersey cow, imported by T. S. Cooper \& Sons. Photograph by the author.

In one year Jacoba Irene made 953 pounds of milk fat, which is a wonderful record. Jerseys are common in the more thickly populated states, and are great favorites at the fairs. In the breed tests of dairy eattle held at the great expositions, the Jerseys have usually ranked at the top, especially at Chicago in 1893, and at St. Louis in 1904. Cattle of this breed have brought very high prices. In 1911, the bull 
Noble of Oaklands sold for $\$ 15,000$, and the cow Lady Viola for $\$ 7,500$, the highest prices for a male and female of this breed.

The Holstein-Friesian breed of cattle came originally from Holland. Here the people have kept dairy cows for centuries. The country is very low, much of it lying below sea level, the water being held back by dykes. There are many meadows that are separated by canals. On long, narrow strips of pasture, with water on each side, one sees beautiful herds of black and white cattle, a most common summer sight in Holland. We do not know the origin of these cattle. They are perhaps descended from the Giant Ox. The present cattle are usually black and white, though red and white rarely occur. Cattle were brought to America from Holland by the early Dutch settlers of New York and vicinity. In 1795 the Holland Land Company sent some cattle to central New York. Later on, Dutch cattle were taken to Vermont and other Eastern states. Along in the middle and later part of the last century many were imported into America. This is our largest breed of dairy cattle, and mature bulls often weigh from 2000 to 2500 pounds, and cows from 1200 to 1500 pounds or more.

The most striking features of the Holstein-Friesian are the large size, the black-and-white spotted color, and the big udders of many of the cows. The heads incline to be a trifle long and narrow, the horns seem small for such a large breed, the body is capacious, the rump is long and frequently steep, and the thighs are large and in many cases tend to be somewhat thick and beefy. The ulder is a notable feature of the cows, some being immense in size and capacity. Several cows have produeed over 100 pounds of milk each in a day, and ycarly records up to "ven more than 25,000 pounds of milk are established. The milk contains usually a small per 


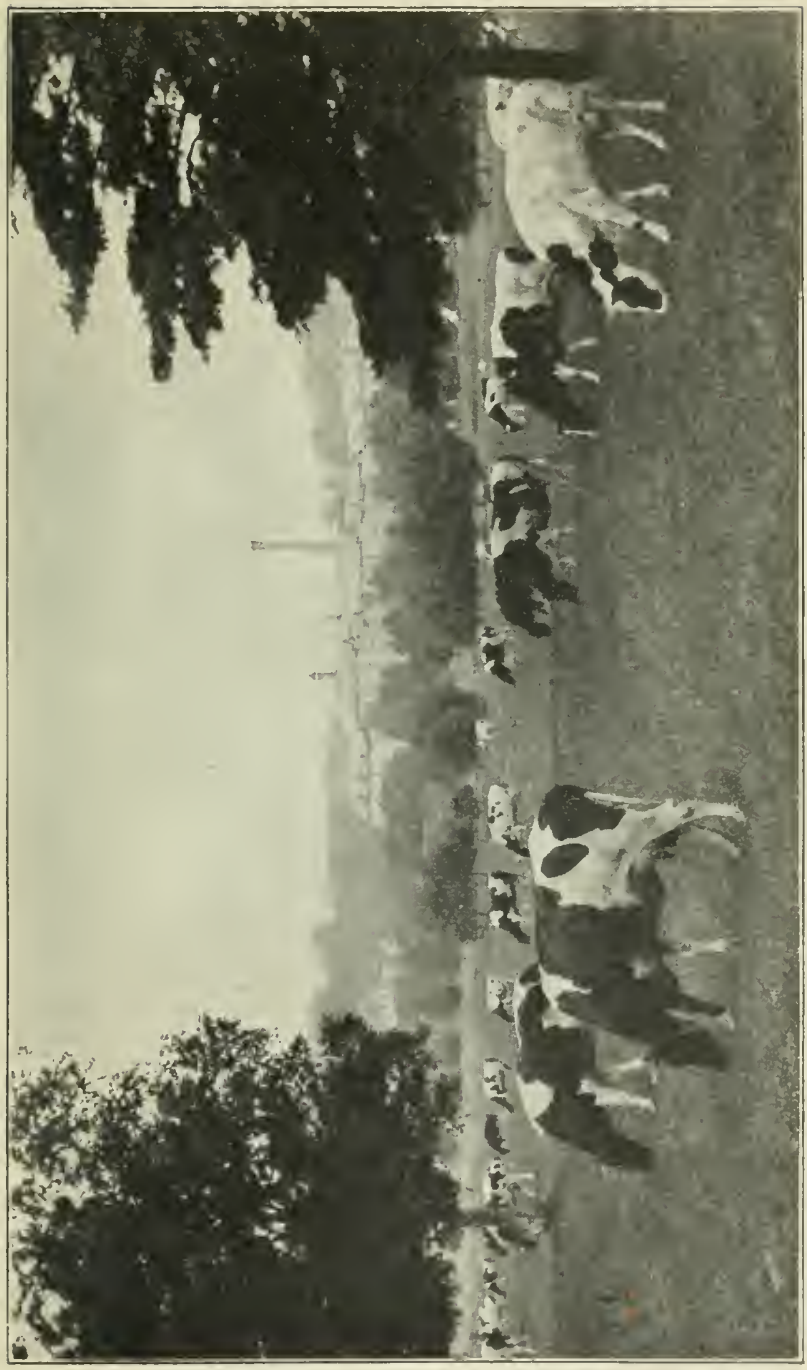

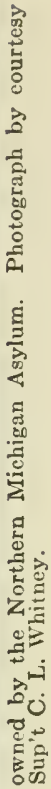

ह

.

:

!

$\frac{ \pm}{0}$

도

항

옳

4

लूं

定 
cent of fat, 3 per cent being common, and 4 per cent unusual. The breeders are now endeavoring to produce cows that yield a milk richer in fat, and with considerable success. On account of the large amount of milk produced, the butter-fat even in a day may amount to a very important total. The cow Banostine Belle DeKol produced 27,400 pounds of milk in a year, containing 1058 pounds of

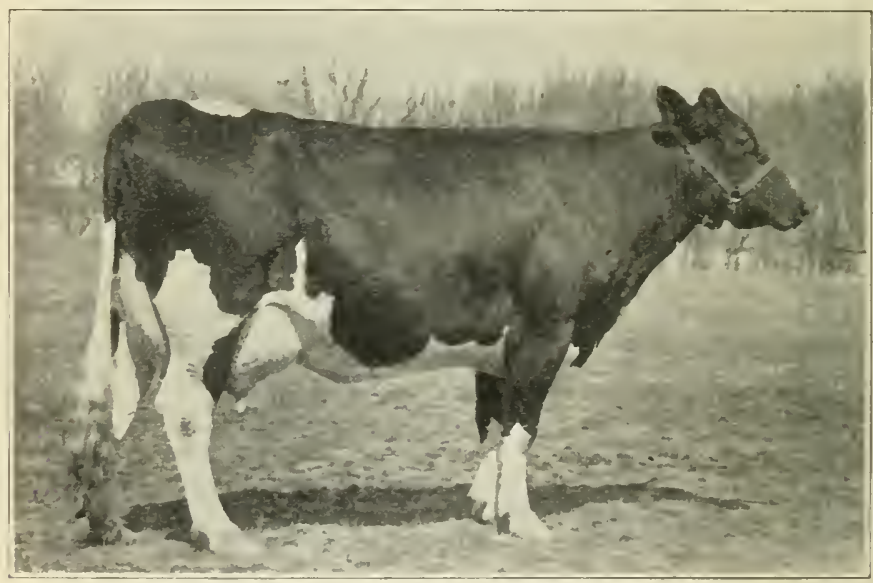

Fig. 36. Pietertje Maid Ormsby 7\$051, a Holstein-Friesian eow that produced $1452 / 3 \mathrm{Ibs}$, butter-fat in 30 days, a world's record. Owned by J. B. Irwin, of Minnesota. Photograph from the owner.

butter-fat, a world's record. A very large number of Holstein-Friesian eattle are registered in the Advaneed Registry (A. R. O.) of the Holstein-Fricsian Association of North America, for having produced at least a certain amount of milk or butter-fat within a definite period under the superintendence of a representative of an experiment station or agrieultural college. This breed is widely distributed in America, though it is best known in the more thickly settler 
Eastern states and in the Middle West and Northwest, and is constantly growing in favor. The great feeding and producing capacity of the cows and their quict disposition have added much to their popularity. The bulls are like all dairy bulls, and tend to be nervous and often mean in disposition. There are three recognized types of this breed, -(a) the thin-fleshed, wedge-shaped type; (b) those that carry somewhat more flesh; and (c) those that are rather

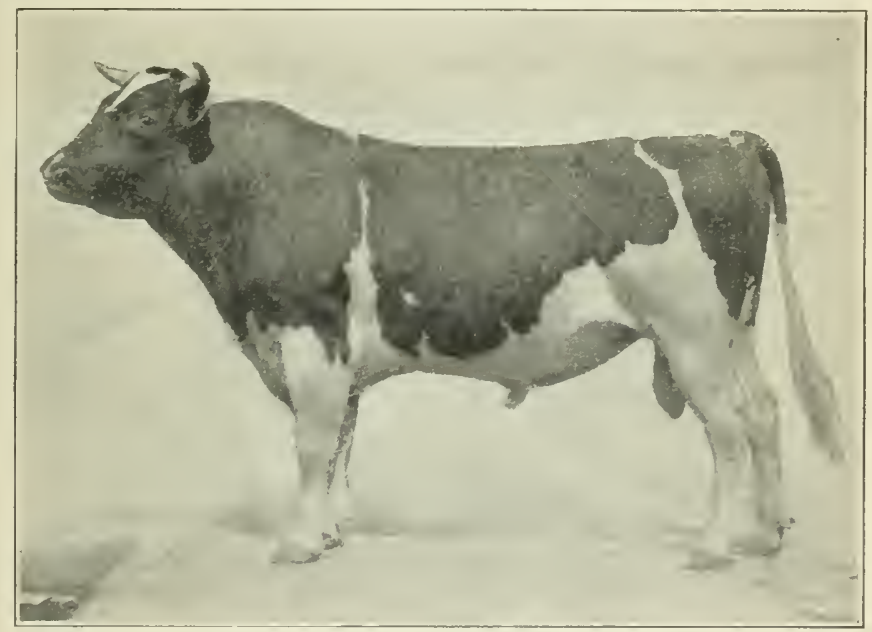

Fig. 37. Jewel of IInme Farm. A Holstein-Friesian bull, famous as a prize winner, owned by W. B. Barney, of Iowa. Photograph by the author.

broad over the withers and thick in the quarters, and show more beefiness than dairy cattle men usually admire. Many people approve the medium between the two extremes, if the cow is a satisfactory producer of milk. A bull of beefy form, with a thick pair of thighs, is not to be commended. Holstein-Friesian cattle mature somewhat slowly as compared with the Jersey. 
Guernsey cattle originated on the island of Guernsey, another of the Chamel Islands, and come from much the same ancestry as the Jersey. The people of Guernsey adopted plans of keeping out foreign cattle similar to those of Jersey. However, the earlier Guernsey cattle show less careful breeding, and as a whole, have not been selected and improved as much as those on Jersey. Guernsey is a triangular, hilly island, of about 12,000 acres in area, and supports a population of perhaps 40.000 people. The climate is balny and healthful. The people make a specialty of flowers, vegetables, and cattle. The island of Alderney is officially a part of Guernsey, and the cattle on this island are the same as the Guernseys, being so considered by Guernsey and by American breeders. In early days, though not at present, all the cattle from the Channel Islands in England and America were called Alderneys.

Guernsey cattle resemble Jerseys, but are somewhat larger and are usually yellowish or reddish fawn in color. White spots are very eommon. As with the Jerseys, a very light creamy ring of hair is found about the muzzle, and a similar or light shade of fawn occurs around the eyes. A fleshcolored muzzle is preferred by breeders, a dark one not mecting with approval. Mature bulls weigh about 1500 pounds, and cows 1050 pounds or so. Guernseys are usually of a quict disposition, and the bulls are perhaps less nervous than are Jersey males. They are often rather plain of head and rough of shoulder and appear coarser than the Jersey. They are noted for the yellow color of the skin and seeretions, the milk being especially high in color. Guernsey breeders rarely color theis butter, depending on its natural color. The (ows give a high-class milk, which often tests above 5 per eent fat. Of the eommon dairy breeds, this and the 
Jersey yield the richest milk, the advantage, if any, being with the Guernsey.

The American Guernsey Cattle Club was the first breed association to establish what are known as official tests for milk and butter production, conducted by disinterested experiment station or agricultural college employees. Since the Club began this work, the Guernsey has made a remarkable showing. Some of the largest butter-fat records made

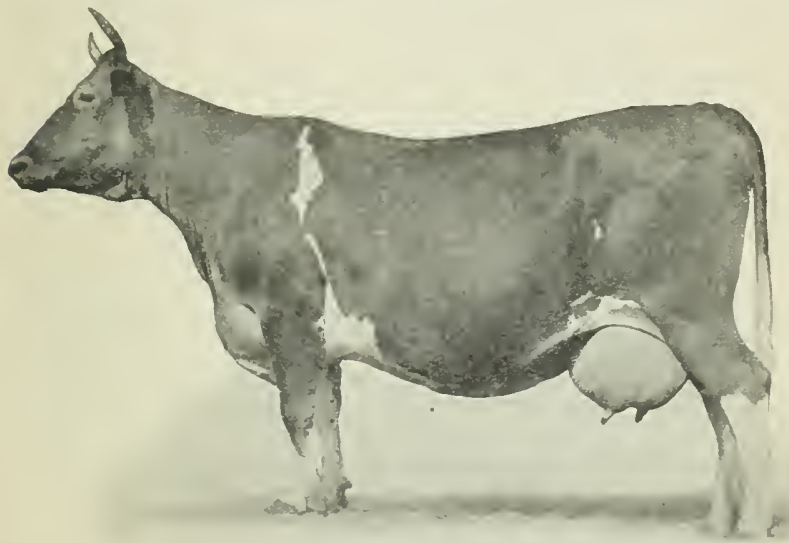

Fig. 3s. Spottswood Daisy Pearl 17696, the champion Gucrusey cow, with record of 957 pounds of butter-fat in one year. Owned by 0 . C. Barber, of Ohio. Photograph from the owner

by cows of any breed have come from the Guernsey. Dolly Dimple produced over 18,000 pounds of milk in a year, containing 907 pounds of fat; and Spottswood Daisy Pearl finished a year's record in January, 1912, of 957 pounds of butter-fat. For the number of Guernseys in America, an unusually fine shoming has been made in official tests.

Guernseys were first brought to this country about 1850 , and were established in the vieinity of Philadelphia and New 
York. Even now the breed is of somewhat limited distribution, being found largely in the Eastern states. There are many herds in Wisconsin, and some important ones are in Iowa, Illinois, and Ohio. These cattle have never secured a strong foothold in the South, where Jerseys are very common. There are many fine Guernsey herds in England, where the breed has made an excellent reeord.

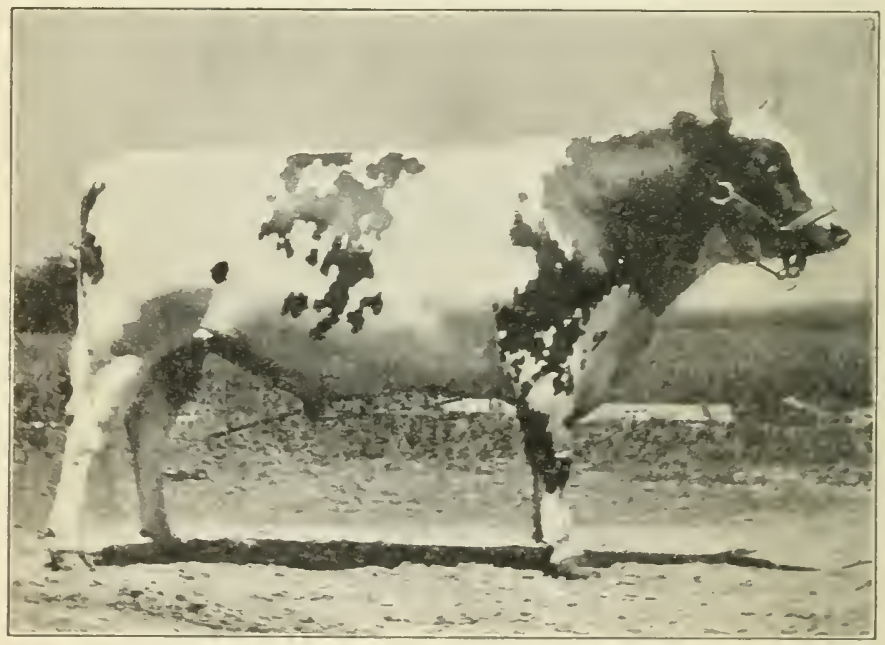

Fig. 39. Bargenoch Bonnic Scotland, an Ayrslire bull, owned by John Sherwin, Cleveland, (). Photograph by the author.

The Ayrshire is a Scotch breed that originated in the region Robert Burns has marle famous, the county of $A \mathrm{y}^{\mathrm{r}}$ in southwest Seotland. It has rather a cold, damp climate in winter, but there is good grazing in summer. Except near the sea, the country is more or less hilly. The Ayrshire is a dairy breed, and one of the youngest of the prominent breeds. Cattle were taken to the Ayrshire country from various places, for Shorthorms, Highland, Dutch, Guernsey, 
Devon, and Hereford cattle are said to have been owned by the farmers of that region. From the mingling of color of these breeds we get the red, brown, and white markings that are features of the Ayrshire. At the beginning of the nineteenth century there were cows in southwest Seotland that were famous milkers, and by offering prizes for competition, the Seotch people have still more encouraged large milk production. The mature Ayrshire bull weighs about 1500 and the cows nearly 1100 pounds. While a true dairy breed, the Ayrshire inclines to be a trifle fleshy, with more thiekness over the withers, along the back, and about the thighs, than have the Jersey or Guernsey. Some of the bulls are quite too beefy for the best dairy form, and these cattle fatten the best of any dairy breed.

Very striking features of the Ayrshire are the

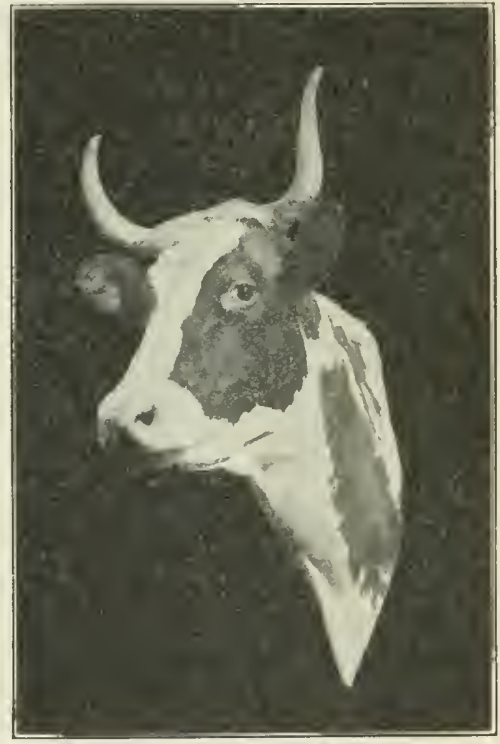

Fig. 40. A fine example of breed character as seen in an Ayrshire head. Photograph from MIr. C. M Winslow. head, with its rather long, large, and erect horns, the red and white, or brown and white color, with white most abundant, the capacious body, and beautiful udder. No other breed of dairy cows has such a uniformly well-developed udder as the Ayrshire, the forepart being much extended, and the rear udder carried well up behind. At a big show these dairy 
cattle, without exception, make the most uniform and attractive exhibit of all breeds. The milk is of a good, standard quality, testing usually from $3 \frac{1}{2}$ to 4 per cent fat. It makes excellent cheese, and most of the famous cheddar cheese of Scotland is made of Ayrshire milk.

Ayrshires have not been extensively tested in America, but cows easily produce 6000 to 7000 pounds of milk a year. The cow Netherhall Brownie 9th, in 365 days ending in 1911, made over 18,000 pounds of milk, which contained 821 pounds of butter-fat. This is the best record for a cow of the breed. Ayrshires are not common in America, except in Canada and the northeastern United States. A few herds are found here and there in the Western states, as far as the Pacific slope. Cattle of this breed are well distributed in northern Europe, in South Africa and Australia. Ayrshires are hardy and do well in the cooler sections of the world where the winters are long. They were first imported into America probably in 1822, and have been brought here in a modest way at various periods ever since. They do not bring as high prices, as a rule, as Jerseys, Guernseys, or Holstein-Fricsians.

Less common breeds of cattle found in America are the Devon, Red Polled, Brown Swiss, Dutch Belted, Ficry, Dexter, and French Canadian. The following are some of their more important characteristies:

The Devon is red in color, and originated in Devon, southwest England. It is a breed that is found to be either beefy or dual-purpose in form. It is a very old hreed, and was brought to America by the early settlers of this country. Devons are not popular, and hut fow hords exist. It has lost ground in this country while other breeds have gained.

The Red Polled, as its name shows, is red, and without horns. The breed originated in Suffolk and Norfolk coun- 
ties in eastern England. Red mulley cattle have been known in America since the early settlement of the country, but the first importation of the breed recorded was in 1873. These cattle are considered good for both beef and milk production. The cows make a very good grade of milk, but as a rule are not heavy producers, although some excellent milk records have been made. Red Polled cattle are most common in the Middle-western states.

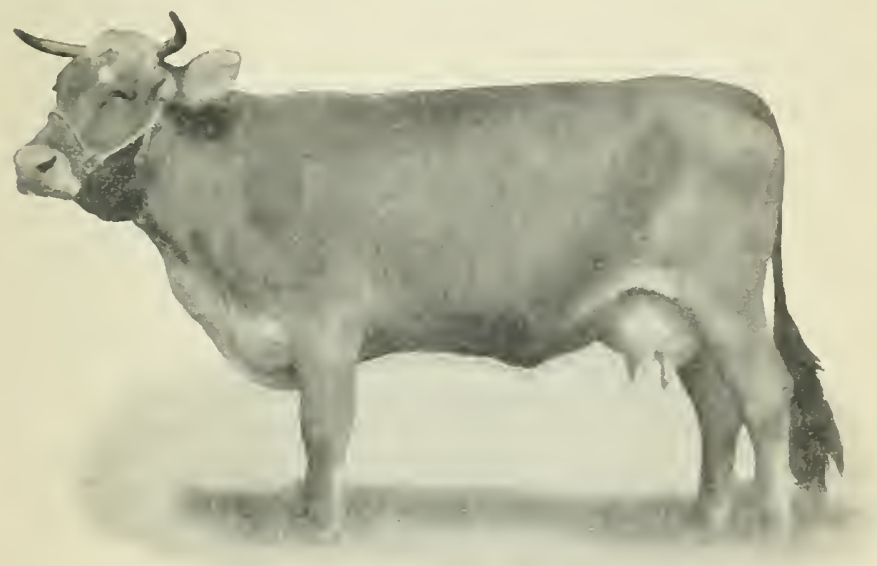

Fig.41. McAlpine, a Brown Swiss cow, first in class at Illinois State Fair. Owned by Mr. E. M. Barton, of Illinois. Photograph by the author.

Brown Swiss cattle originated in Switzerland. In color they are usually a dark brown, with lighter or cream-colored hair about the muzzle and along the top of the back. They incline to be heavy of head and neck, and coarse-boned; are likely to be somewhat fleshy, and often have rather meaty thighs. The cows produce a very good grade of milk. While they often impress one as clual-purpose cattie, the association promoting them has officially declared the Brown Swiss to 
be a dairy breed. These cattle are not popular in America, and but few herds are found in any part of the country, these being mostly confined to New York and the Middle West.

The Dutch Belted breed of cattle was developed in Holland. It is of the dairy type, and is noted for its black color, marked off by a white stripe or blanket of varying width which extends entirely around the body between the hips and shoulders. It has not made much of a reputation for milk or butter-fat production, and so far as public evidence goes, it is one of the poorest dairy breeds. There are very few herds in America, and they attract more attention from their peculiar markings than for actual merit.

The Kerry is an Irish breed that has long been bred in Ireland. It is black in eolor, though white sometimes occurs about the udder of the cow. It is of small size, and will exist where most breeds would starve, hence is the poor man's cow of Ireland. It is strictly a dairy type, and produces an excellent milk, testing about 4 per cent fat. Some of the cows give a large yield of milk, considering their size. There are but few Kerries in America. They are just beginning to attract attention as economical milk producers.

The Dexter is another Irish breed, of uncertain ancestry but closely related to the Kerry. These eattle may be black or red in color, and are the smallest breed found in America. Many of the mature bulls and eows stand only 36 to 40 inches high. The cows often produce excellent yields of milk, testing above 4 per cent fat. Cases are on record of cows of this breed, weighing around 500 pounds, that have produced in a year over 8000 pounds of milk. These diminutive eattle may never be popular for general dairying in Ameriea, but they will grow in furor for family use.

The French Canadian is a breed that has had special development for 200 years or so in Quebee, C'anada. These 
cattle are black or very dark fawn in color, and probably had their origin in France, from the same source as the Channel Island cattle. This is one of the small breeds, the mature cow weighing about 700 pounds. French Canadian milk tests slightly above 4 per cent in fat. Some large milk records are reported from Canada, but the specimens of the breed to be found in the United States do not seem to be important producers. It is regarded as a very hardy breed. There are few herds in the United States, these being loeated in the northeastern portion, though especially in New York.

\section{IF YOU WERE ASKED THE QUESTION, COULD YOU TELL}

1. About the Wild White Cattle?

2. Who Bates and Cruickshank were, and what they did?

3. The characteristics of Shorthorns?

4. When Herefords were first brought to America and by whom?

5. Who "Old Grannie" was?

6. How Aberdeen Angus cattle rank for beef"?

7. About Jersey and the other Channel Islands?

8. How a Jersey cow should be described?

9. Who Jacoba Irene was?

10. How Holsteins rank as milkers?

11. Where Guernsey cattle are most common in America?

12. The characteristics of the Ayrshire?

13. Who keeps pure-bred cattle in your neighborhood, the breeds owned, and which is the most popular?

14. The name of any noted bull or cow in your state, and why celebrated?

15. The best milk or butter record of a cow in your township?

16. Whose cows make the best showing at the creamery? farm?

17. What kind of cattle are kept at the county infirmary, or poor 


\section{CHAPTER IV}

\section{THE BREEDS OF SHEEP}

The origin of the domestic sheep is generally believed to be from several kinds of wild sheep found in different parts of the world. One of these is found in the hilly or mountainous parts of Asia, and is known as the Argali. It is much larger than our domestic sheep, has big horns, and a coat of black or dark-red hair, below which is a covering of white wool. Another form, called the Musmon, is found in the more mountainous parts of Greece and adjacent sections of Europe. Rocky Mountain Sheep are another sort living on the higher mountains of North America. Wild sheep have always been found in the elerated parts of Africa and castern Asia. All of these sheep have certain features in common.

Just how long the sheep have been subject to the control of man we do not know. Neither have we any information as to the wild family from which the domestic form has come. Scientific men have had different views on this subject. Bones of sheep have been found among the remains of the lake dwellers of Switzerland, a people who lived before the dawn of history. The very earliest writings, including the Bible, show man to have had large flocks of domestic sheep, and to have valued highly both wool and meat.

Three distinct classes or groups of sheep may be made, depending largely upon the character of the fleece. These are fine or short, medium, and long or coarse wools. These classes are somewhat due to the sorting over of the fleeces by the wool merchant, who finds that each class serves a 
special purpose in his business. Another grouping is also sometimes made, consisting of the fine-wool, or Merino class, and the mutton breeds. However, this last arrangement is more commonly referred to by shepherds than by wool dealers. There are many different breeds of sheep, some of which are but little known in America, and the following are the only ones of importance in this country.

The Merino is a very old breed that had its important early development in Spain. Here for centuries the Monks and wealthy people owned large flocks that were noted for their very fine wool. As long ago as the first eentury, the sheep of Spain were famous, and 700 years ago the manufacture of wool into beautiful rloth was a great inclustry in that country. When the people of the other European countries learned of the fine wool that was produced there, they sent to Spain and obtained some of the Spanish sheep. Specially selected flocks were taken to Germany and France in the latter part of the eighteenth eentury.

The first Merinos were brought to the United States in 1793. Three head were smuggled out of Spain by William Foster of Boston. He gave them to a friend, who killed them for meat, not knowing how valuable they were, until he later paid $\$ 1000$ for a ram of the same breed. Seth Adams of Massachusetts, later of Ohio, imported a pair in 1801, and in 1802 Colonel Humphreys of Connecticut brought to America nearly 100 head. These Humphrey sheep proved very valuable, and from them some of the best flocks in America started. Much interest followed these two importations. Soon other people began to import Merinos into the United States, and very high prices were paid for them. During 18 months ending in 1811, nearly 20,000 of these sheep were brought to this country. The people became almost crazy over Merinos, and paid very high 
prices, some selling for as high as $\$ 1500$ each. As our country developed, the Merino became widely distributed and but few of any other kind were kept for many years. During this time our people cared but little for mutton, but high prices were paid for wool, for which the Merino was especially valued. These sheep grew greatly in popularity in all wool-producing countries, so that even today there are more sheep of this breed than any other, for immense flocks

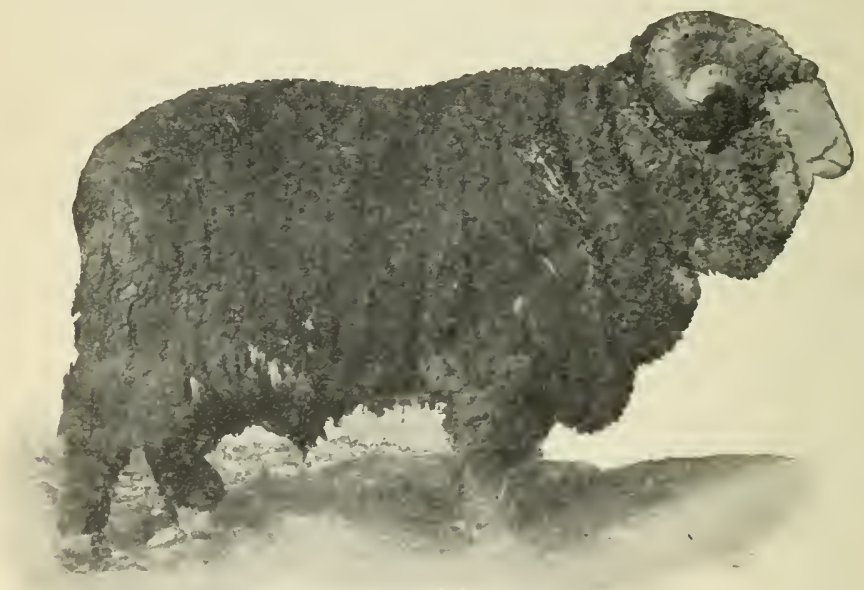

1.ig, 42. A Merino ram owned by S. M. Cleaver, of Ohio. Photograph by the author.

are found in Australia, South America, and over much of the United States. However, the production of wool is growing less profitable, so that shepherds are gradually changing to the mutton breeds, or are giving up their flocks altogether.

A number of different Merino families have been developed in America. They all had their origin in the sheep of Spanish breeding, but in the hands of certain men each 
gradually developed special features. In this way families of Merinos were established. For a great many years all sheep that had heavy folds over the body were known as Spanish Merinos. Later the people came to refer to sheep of this class that had been produced in America, as American Merinos. In time, a larger sheep, with few folds or none, developed, that produced a longer and somewhat coarser grade of wool especially suited for certain cloth manufacture. These became known as Delaine Merinos. These sheep also produced a good grade of mutton. Among the Delaines are some family branches of interest, though not widely bred, as for example, the Dickinson and the Blacktop. Most of the Delaine improvement of importance took place in western Pennsylvania and in Ohio.

Some of the most important features of the Merino may be considered here. These sheep produce the finest wool known. It is so fine that over 1000 fibers may be laid side by side within an inch space. The fleece covers the entire body, often coming down over the face to the nostrils, and covering the legs even to the toes. If the sheep has folds or wrinkles over the body, we expect to get the finest and shortest wool. The less folds over the body, as a rule, the larger the sheep and the longer and coarser the fleece. Average Merino wool is about $2 \frac{1}{2}$ inches long.

On the outside of the fleece we usually find more or less grease or oil, or yolk, as it is called, mixed with dirt, most of which easily washes out, even in cold water. The eloth manufacturer removes this by scouring. Some fleeces in this operation lose 75 per cent of their weight. Wool buyers do not like a very heavy amount of oil, on account of this shrinkage when the wool is scoured. A common weight for a fleece is eight or ton pounds, but some have weighed over 40 pounds when taken from the sheep. Rams 
weigh at maturity 130 pounds or more, and the ewes around 100 pounds. Those with folds weigh the least, while the smooth-bodied ones are larger. Merino sheep are very hardy and thrive on ordinary pasture. They run together in flocks much better than any other breed, and so are easily managed by shepherds and dogs when on great ranges or pastures. Large numbers of sheep that have Merino blood in them come into the markets, but really are of mutton parentage. They make excellent mutton, and are liked by butchers beeause they are neither too large nor too fat. More purebred flocks are found today in Ohio than in any other state, although New York, Pennsylvania, and Michigan have flocks also. West of the Mississippi there are large numbers of these sheep on the range.

The Rambouillet sheep is a breed of Merinos that has been especially developed by the French Government. In 1786 Ting Louis XVI of France sent a man to Spain to bring back a selection of Merinos. These were brought to one of the royal farms about 40 miles west of Paris, at a torn named Rambouillet. Here on this estate the government has bred the descendants of these sheep for 12.5 years. They were introduced into America in 1810, and for many years were known as French Merinos. About 1890 the name Rambouillet eame into use, and now the term French Merino is rarely used. These sheep have all the common features of the smooth-bodied Merino. However, it is the very largest family of this breed, and has been at times called the "Elephant Merino." The ram weighs about 185 pounds at maturity, though some have weighed 250 pounds, and the ewes weigh around 150 pounds. This family is known as a mutton Merino, and a mutton form is an important feature. Thus one may expect a broad back and a thick leg of mutton in a good specimen of the Rambouillet. 
One on two folds or more are not considered objectionable when found about the neck and breast, but the borly should be smooth. The flecee of 12 months' growth should be about three inches long, and compact over the body, with but little oil or dirt on the outside. Well-bred Rambouillet flocks shear about 10 or 12 pounds of wool per head. These sheep have grown in popularity in recent years, for they mature early, are hardy, and seem well suited to most parts of the United States where sheep husbandry thrives. On the Westem range, and on the Pacific slope are found some of the very best and largest flocks in America. Many choice flocks are also omned in Ohio. Rambouillet sheep have been bred to a considerable extent in northern Germany, and very large numbers are now found in the Argentine, in South America.

The Southdown is one of the oldest breeds of sheep. Its native home is on the Southdown hills

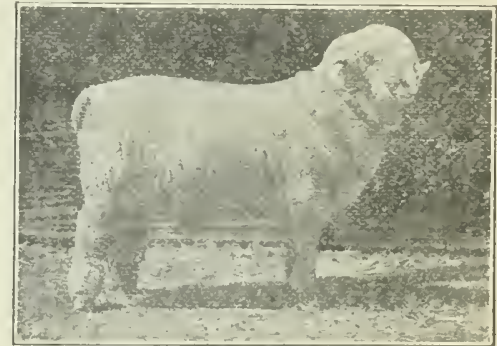

Fig. 43. A Rambouillet ram lamb, bred by Illinois University. Photograph from Prof. W. C. Coffey. in Sussex county in southeast England. These hills are of white chalk, and are covered with soil on which grass and the small grains do very well. About 1775 a man named John Ellman, who lived in Sussex, began to improve the native sheep and kept at this work for over 50 years. Through his efforts the Southdown developed into the best mutton sheep known, having splendid vigor, fattening easily, maturing rapidly, and producing a carcass with but little waste at slaughter. While the flece was not heavy, its quality was fine. Following Mr. Ellman 
came Jonas Webb, who lived north of London, at Babraham, near the city of Cambridge. He was also one of the greatest English breeders. His Southdowns had more size and were a still better mutton sheep than were Ellman's. As a mutton sheep, the Southdown has occupied a most important place for a century or more, being still eonsidered the model sheep for that purpose. It has been used to help improve more breeds than has any other. Southdowns were first imported into America about 1800, and since then many others have been brought here.

The Southdown has been noted for its short, neat head, which is more or less covered with wool down orer the reddish-brown face. It has a short, thick neck, broad chest, wide back, thick meaty leg of mutton, and short red-brown legs. No other breed matures earlier, and it is not lacking in hardiness. Southdowns are well suited to grazing on the better class of pastures, but are not so good for the range and poor pastures as are some others. The flesh is very fine of grain and is not inclined to be overfat. Butchers especially admire this sheep because it kills out so wcll, with small amount of loss. The Southdown, or sheep with more or less of Southdown blood, have won more prizes in fat-stock shows where the carcasses were considered, than has any other breed. At our great International Live Stock Exposition, the Southdown has usually won the grand-championship on the dressed carcass exhibit. Mature rams weigh about 175 pounds, and the ewes 135 pounds. These shecp have bcen criticised as being too small for the American farmer. The averagc flecce is short and light of weight, though of fine quality, and this has also made the brced generally umpopular in America, although it is looked upon with more favor in the Southern states. In spite of thesc criticisms, the 


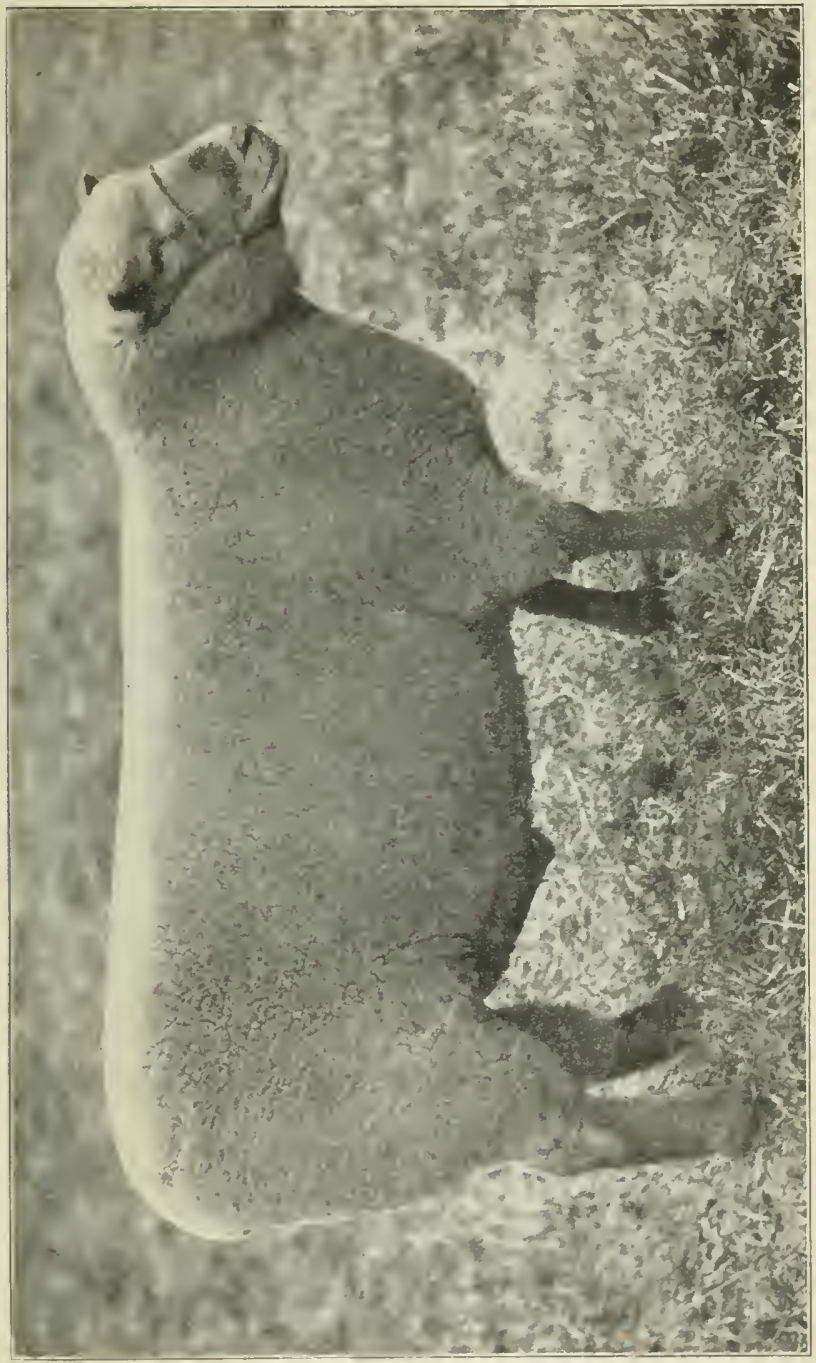

룽ㄱ

론

픈

르응

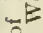

o

ํํㄹ

क

氖

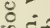

क

हี

ت용

పొ

㟧动

$\varangle_{0} \circ$

인 모

을

政

$\stackrel{5}{5}$

हึँ

के

로규

5 은

Gaim

ริํำ

글

בิำ

क.

드음 미

员

ีํㄹ을

3.:-

드응응

$-\frac{0}{2}$

远.

z

¿

छ

톡연

एकำ

๓⿴囗十

당

$+\square$

든

E

(5)

$\vec{ت}:$ 
breed commands universal respect, and flocks of Southdowns are found all over the civilized world.

The Shropshire sheep originated from a number of different types native in and about the county of that name in western England. This is a rather hilly region, with many fine pastures, and is well suited to these animals. A number of different men were interested in the improvement of

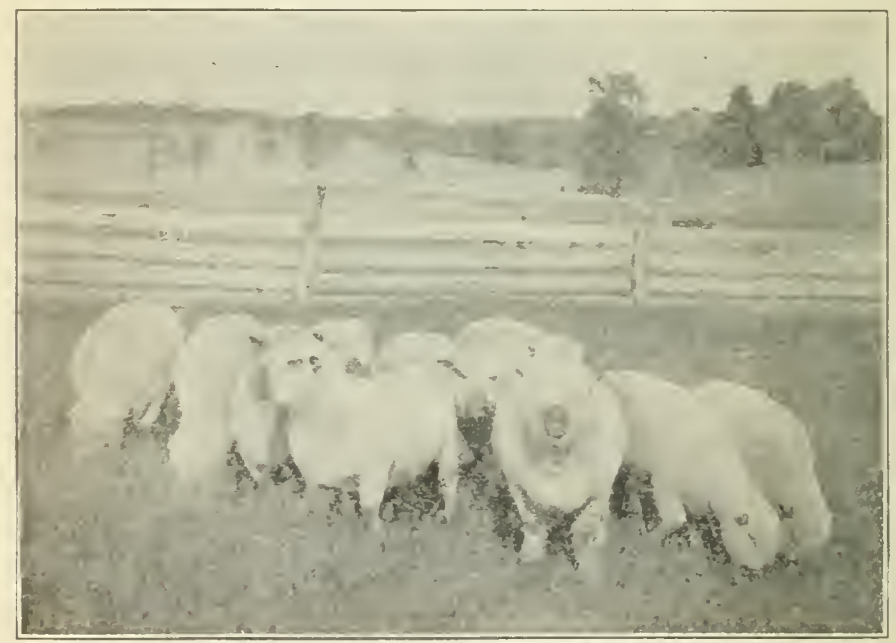

Fig. 45. A group of Shropshire sheep on farm of H. M. Brown, of Ohio. Photograph from $W$. E. Duckwall.

the Shropshire, prominent among whom were Messrs. Meire and Adney. Some of the early sheep were very coarse and had horns, and Mr. Meire worked to improve the quality, to get rid of the horns, and to develop a better mutton sheep. In this he succeeded. Shropshires became somewhat prominent in England about 1853, when they were first exhibited at the Royal Agricultural Society Show. About 
1880 much attention was given the breed, and large exhibitions were made at English shows. These sheep were first imported into America in 1860, by Samuel Sutton, of Maryland. Twenty years later they were imported in larger numbers, and since then thousands have been brought to the United States, where this is the most popular of all the mutton breeds. In size the Shropshire is medium, the mature rams wcighing about 225 pounds and the ewes about 160 pounds. The head often has a covering of wool, or "cap," down to the nose, which is covered with dark brown or nearly black hair. The back is broad, the leg of mutton very good, and the body is usually deep, showing good feeding capacity. The legs are dark brown in color like the face, and are covered with wool to the knees in front and to the ankles behind. The quality of mutton is most excellent, being second to the Southdown only. The fleece is usually about $3 \frac{1}{2}$ inches long, and is of very good quality. A twelve months' growth from fair specimens of the breed weighs about 9 or 10 pounds. The combination of good size of body and weight of flecce has done much to make this breed popular with American farmers, as a great general-purpose sheep. Besides this, Shropshires are the most prolific breed we have, many ewes having twin lambs. Flocks are very common all over the so-called corn belt of the United States, especially east of the Mississippi and in Canada. The American Shropshire Sheep Association is the largest organization of its kind in the world, and has done much to promote the breed.

The Oxford Down sheep comes from the county of Oxford, in south-central England. It is a beautiful rolling country, with good pastures, and where wheat and small grains thrive. This is one of our youngest breeds of sheep, and comes from a combination of Cotswold and Hampshire blood. About 
1833 a man named Druce began to breed these sheep, and finally produced one of the largest English mutton breeds. For a long time the wool, though abundant, was rather inferior, but the size and the mutton quality of the sheep made it popular. A few of these sheep were brought to Delaware in 1846, and since then the breed has been much improved and has been gaining in popularity in America. As already stated, it is a large breed, the rams at maturity

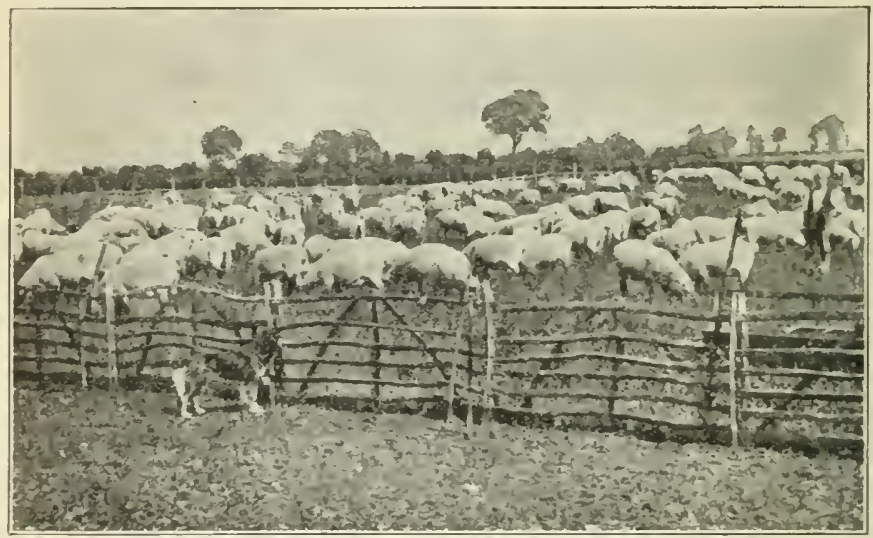

Fig. 46. A group of Oxford Down sheep on the farm of George Adams, England. Notice the style of hurdles used for temporary fencing. Photograph by the author.

often weighing 275 pounds or more, and the ewes about 200 pounds. The color of the hair on the face, ears, and legs is a very dark brown, quite like the Shropshire. Oxfords are not so hearily wooled over the head, and often the face is rather free of wool, and the ears incline to be rather smooth and large. Typical specimens have quite wide backs, fairly good legs of mutton, and deep bodies. During recent years the breed has been much improved, the flesh growing 
finer in quality, and the fat being laid on more smoothly. The fleece, which frequently weighs 12 pounds, is longer, more open, and coarser, than that of the Shropshire. This is a breed that has made a favorable impression on farmers in the states of the Middle West, where fairly early maturity, size, and heavy fleece are wanted. The ewes are quite prolific, and though not equalling the Shropshires, make a very good showing. The Oxford may be regarded as one of the most promising breeds for future development. Recently flocks have been extensively distributed to many sheep-growing countries. There are more of these sheep in Ohio, Indiana, Illinois, and Wisconsin than elsewhere in America.

The Hampshire Down sheep, like the Southdown and Oxford Down breeds, originated in southern England and under much the same conditions of climate and soil. Their ancestors were of two kinds, one with white faces and horns, and the other

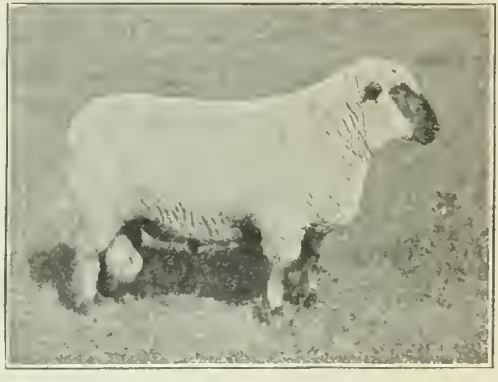

Fig. 47. A Hampshire ram, grandchampion at Louisiana Purchase Exposition, 1904. Photograph from Chilmark Farms, New York.

with dark faces and horns. Southdown blood was mingled with these two, from which came the more improved Hampshire, without horns and with an almost black face, ears, and legs. A man named Humphrey was the most important early improver of these sheep, and later, James Rawlence did much for them. The Hampshire is one of the largest breeds, mature rams often weighing 250 pounds, and ewes nearly 200 pounds. The head is one of the striking features of the breed. The nostrils, lips, and face are 
quite black; the nose is very strong, or Roman in character; and the ears are dark, very large, and incline forward in a heavy style. Wool rarely extends much beyond the forehead. The body is large, and the form is of the usual mutton type. Hampshire sheep often seem somewhat coarse of bone and large of limb. The fleece is about 4 inches long, inclines to be coarse and open, and usually does not shear much above 7 pounds with 12 months' growth. Hampshires have long been popular for early or spring lambs, which are considered of excellent quality. The breed is undoubtedly growing in faror, and during the past few years large importations have been brought to the United States. In the more fertile sections where feed is abundant, the Hampshire makes an excellent shoring, as it does in its native home in England. The breed is widely distributed in North and South America, in Europe and Australia. In the United States, the important flocks are kept mostly in the Northern states east of the Mississippi.

The Dorset Horn sheep receives its name from the rcounty of Dorset, in southern England, where it has long been bred. It is an improved form of two native, horned, white-faced breeds found in Dorset and Somerset counties. The modern Dorset Horn belongs to the middle-wool class, and is of medium to large size, rams weighing about 225 pounds and ewres 165. Both sexes have homs, those of the ram at maturity being large and having spiral turns, while those of the ewes are small, and bend in a simple curve around toward the face. The head, ears, and legs have a covering of white hair, and the nostrils are of flesh color. The neck is often short, the back wide, and the body of large capacity, with a fair leg of mutton. Dorsets are popular as lambs, and for mutton, although the quality of the mutton is not of the best. The lambs feed well and lay on flesh 
rapidly. As wool producers, this is a breed that should do better. The fleece tends to be short and the weight light, ranging around 6 pounds for average animals. These sheep were first brought to America in 1885, and while there are

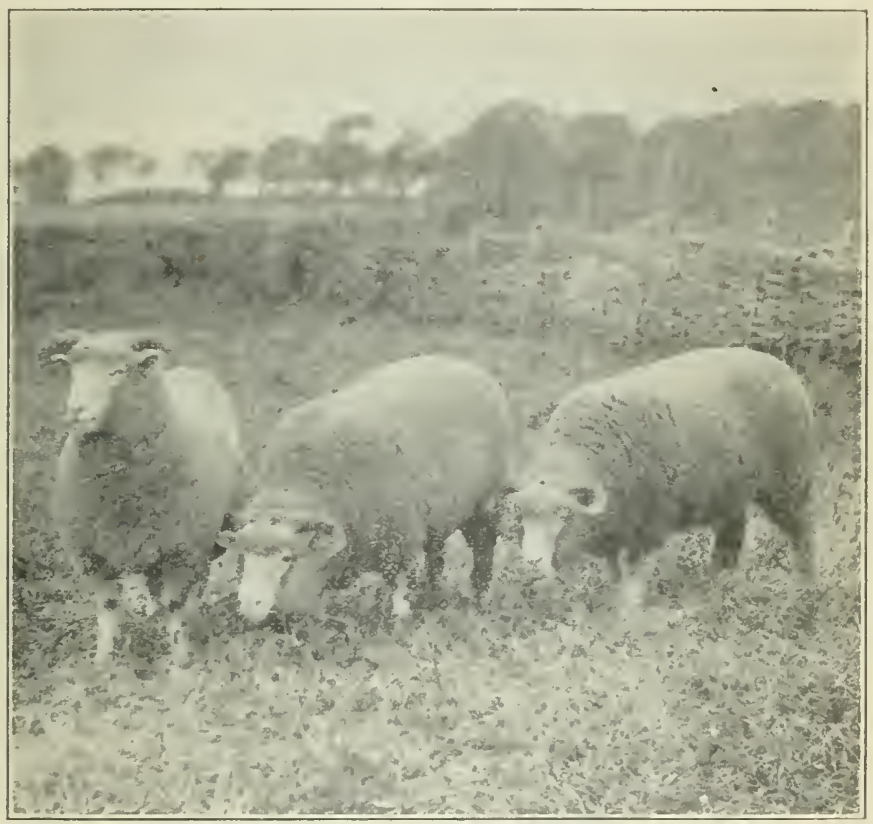

Fig. 48. A pen of Horned Dorset ewes, champions at the show of the Royal Agricultural Society of England. Photograph from the National Stockman and Farmer.

numerous flocks in the Eastem states, the breed can hardly be called popular as yet.

The Cheviot sheep comes from the Cheriot Hills in the border country between England and Scotland. Here the land rises into high grass-topped mountains nearly 4000 
feet above the sea. Grass is the universal erop, and here this breed of sheep has been raised for long beyond a century, and gradually improved during the passing years. Today the Cheviot is a medium-wool, fair-sized sheep, the rams weighing around 200 pounds at maturity, and the ewes 150 pounds. This is one of our most beautiful breeds. The head is entirely free of wool, and the face and ears are covered with white hair, with black specks occasionally

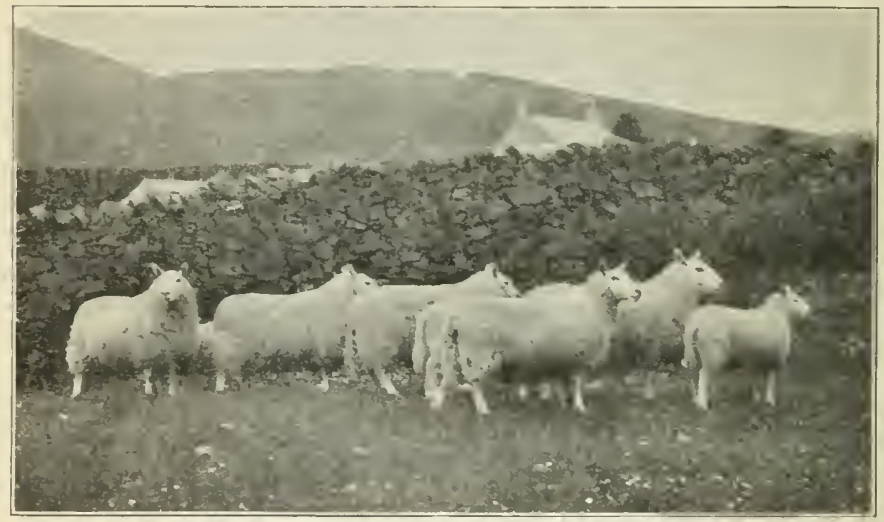

Fig. 49. Cheviot rams on pasture in Scotland. Owned by John Elliott. Photograph by the author.

occurring. The nostrils are black, the nose tends to be a bit Roman, the eye is large and prominent, and the erect ear is usually pricked up as though listening. The Cheviot inclines to be somewhat narrow of back, with a moderate depth of body and fair leg of mutton, though in reccnt years it has been much improved. The flecee covers the body to the back of the ears and down to the kmees and hocks, the rest of the leg being covered with white hair. 'The flece tends to be somewhat open and is usually about $3 \frac{1}{2}$ inches 
long and a year's growth weighs 6 or 7 pounds. The fiber inclines to be coarser than that of the Shropshire, American breeders using the latter for a standard.

Cheviots are very hardy, and in their native home on the mountains rely altogether on grass the entire year. They are active and independent, and do not floek as do other breeds. For this reason the breed has never been suited to the range country. The quality of Cheviot mutton is very superior, having very fine grain, and lacking surplus fat. In mutton carcass contests in the English and Scotch shows, the Cheviot has always held a high place. It is not widely distributed outside of its native home, though found in the United States in New York, Ohio, Indiana, and in other states of the Middle West.

The Suffolk sheep comes from the county after which it is named, in southeastern England. It belongs to the medium-wool class, and is chiefly a mutton breed. The head, ears, and legs of the Suffolk are distinctly black in color. This gives a group of these sheep a very striking appearance. Mature rams weigh about 250 pounds and the ewes 175 pounds. The fleece is not heavy. Suffolks are not extensively bred in England, and but few of them are to be found in America. In fact, they are very rare here, and are not often seen at our sheep shows, neither have they been much advertised in America.

The Tunis sheep takes its name from Tunis, in northern Africa, where it is supposed to have originated. In 1799, General Eaton, United States Consul at Tunis, received a gift of a number of these sheep, two of which survived a voyage to America. Other importations followed this one of General Eaton. These early importations were kept in the Eastern and Southern states, and-little was done to improve them. They are peculiar in having a large, fat 
tail, and have often been ealled "Fat Tailed Sheep." In recent years, especially since about 1893 , they have been bred in small flocks, in different parts of the country, but especially in Indiana. They are of medium size, with brown, or mottled brown and white faces, and brown legs. The tail is eut off soon after birth, as with other lambs, but the hind parts of the Tunis are somewhat heavier than corresponding parts of other breeds. The Tunis makes an excellent feeder, and lambs of this breed have sold for high prices on the market, and have met with much favor from stock buyers. The fleece is of good quality, areraging about

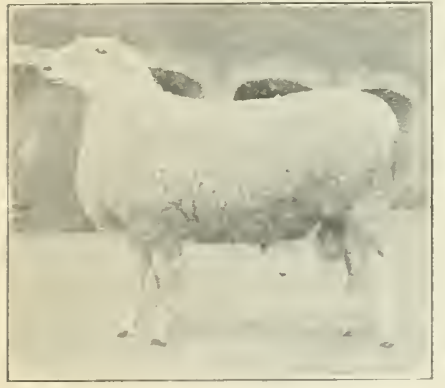

Fig. 50. A Border I.eicester ram. Photograph by the author.

3 inches long, and frequently containing red or brown fibers. But few of these sheep are to be seen, and fairs generally make no arrangement for them in the premium lists.

\section{The Leicester sheep (pro-} nounced Lester) originated in central England in the county of that name. Here Robert Bakewell, one of the most famous live-stoek breeders in English history, developed and improved the native stock into the New Leicester. This was really the first improved breed of sheep known in England, and for a great many years it was extremely popular. Some of these sheep were brought to Ameriea, it is said, before the War of the Revolution. In 1800, Now Leicester sheep were known about Philadelphia. In the early part of the nineteenth century, many were imported and sold for high prices. This is a large breed, and belongs to the long, or coarse-wool elass. The entire head and ears are eovered with white hair, the 
wool not growing beyond the back of the head. The ears are large but thin, and are usually carried in an erect position. The nostrils are black, the nose is somewhat prominent, and the eye bold and attractive. The Leicester has a full, wide breast; broad, flat back; wide rump; and fair leg of mutton. The body form is broad rather than deep, and sometimes these sheep appear long of leg. They fatten rapidly, and the rams at maturity weigh around 250 pounds, and the ewres 175 pounds or more. As mutton producers, they are not popular beeause they lay on too much fat. They require good pastures, and are not the hardiest sheep in the world. This, with their size, aceounts for there being so few of them today either in America or elsewhere. The Leicester is the smallest of the long-wool breeds, and has a curly fleece that does not shear very heavily, 7 to 9 pounds being about a year's growth. Once a popular breed, this is now the least known in America of all the so-called common breeds of sheep. In northern England, in the border country, is an improved form or family known as the Border Leicester, which is the more common type today. This family has a more vigorous constitution and has a clear white face, while the old breed has a bluish tint to the skin.

The Cotswold sheep gets its name from the fact that in early times in England these sheep were sheltered in what were called "Cots," and were pastured on the treeless hills knomn as "Wolds." That was in southwest England, where this breed has been kept for centuries. It is written that in 1464 King Edward IV gave permission to transport some Cotswold sheep to Spain. About 100 years or more ago, Cotswold and Leicester floeks were mixed a great deal in blood, by which it is said the former was improved. These sheep were brought to America as early as 1832, and at one time were very popular, especially in the states cast of 
Illinois and north of Tennessee. This is a large, long-wooled breed, larger than the Leicester, mature rams weighing from 250 to 275 pounds, and ewes 200 to 225 pounds. The head is somewhat large, and is usually white, though it may be gray or brown in tint. The nose is rather prominent, and the ears incline to be large and are carried somewhat heavily. If the forehead of the Cotswold is protected, long curly locks of wool hang down in front, often hiding the eyes. This breed has a broad breast, wide, flat back and broad rump, and shows a greater

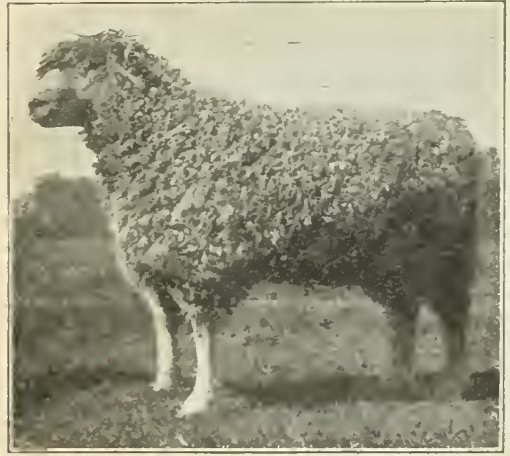

Fig. 51. A Cotswold ram. Photograph by the author. width than depth of body in the best specimens. While the Cotswold feeds very well, if on good pasture and under favorable conditions, it is not a breed suited to scant pastures. The well-fattened carcass is too large, coarse, and fat for the present demand. The fleece is coarser and the curly locks larger than with the Leicester. Crood Cotswold wool is noted for its lustre, having a shiny, glistening quality, rather peculiar to this and the Lineoln breed, and is much valued by the English breeders. A twolve months' fleere is usually from 8 to 10 inches long, and weighs about. 10 pounds. There are not many Cotswold flocks in the United States, and the breed is more popular in Camada than here. The demands for a smaller sheep and a different grade of wool make it difficult for this breed to become popular in America. 
The Lincoln sheep comes from the eounty of that name on the east coast of England. This is a very old breed, and its improvement began while Bakewell was improving the Leicester. Some Lineoln sheep were brought to America before 1800, and they have been imported in a small way ever sinee. This is a large breed, being somewhat larger than the Cotswold, and having mueh in common with the latter. The head is large, and is gray or white in color, or gray mixed with white. The wool does not eover the entire

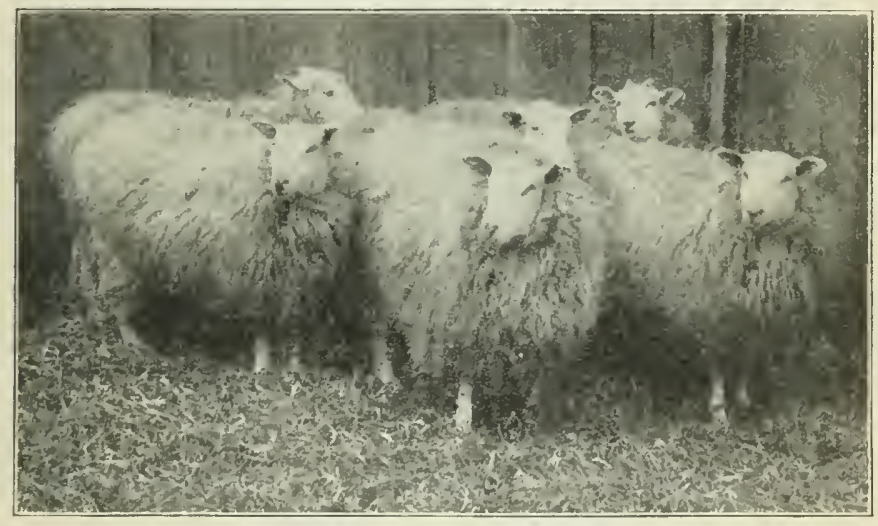

Fig. 52. A group of Lincoln ewes owned by William Shier, of Michigan. Photograph from the American Sheep Breeder.

head, but frequently a small tuft of short locks extends over the forehead. The ears are large and usually have no wool on them. The borly form is much like that of the Cotswold, though perhaps deeper of rib. These shcep fatten easily; but the carcasses get too heavy and have too much external fat for the present-day trade, and so the mutton is not popular. The Lineoln requires good grazing to do its best, as it is too heavy for the hill country. The Lineoln produces a fleece 
in long, wavy locks, not so curly but with the same lustre as the Cotswold. A year-old fleece is usually 8 inches long, and may weigh 10 pounds. Lincoln sheep have grown in popularity in their native home on account of the demand for them in the Argentine, where large numbers are kept. Very high prices have been paid for them in England, and in 1906 a ram sold for $\$ 7600$, the highest sum on record for the breed. In the United States, Lincolns have gained in faror somewhat, although they cannot be regarded as popular.

The Romney Marsh or Kent sheep originated in southeast England, in the county of Kent, on the marshes after which the breed is named. The soil here is low, rich, and marshy. These sheep seem especially suited to the local conditions, not suffering from foot rot as do other breeds. The head and legs are white, the back is broad, and the body is of compact form. These sheep fatten very well on rather limited areas, and make a fair grade of mutton: The fleece weighs about 8 pounds, after a year's growth, and is in good demand. Large number's of Romney Marsh sheep are now found in the Argentine, and importations to America on a small seale have just begun, an association for promoting them having been organized at Chicago in December, 1911. Since it is almost an unknown, untried breed in America, its merits for our conditions remain to be shown. This breed belongs to the middle-wool class.

The Black Faced Highland sheep has long been known in the highlands of Scotland, where it grazes on the grass and heather on the highest mountains. In this breed, as in the Dorset, both sexes have horns, those of the ram being spiral and very large and showy at maturity. Highland sheep have black or mottled black and white faces, with no wool beyond the forehead. While these sheep, which are from small to medium size, produce a very fine grade of 
mutton on their native pastures, they are slow growers, and cannot be ranked as feeders, as we view sheep in Ameriea. Their chief value lies in their adaptability to rough, hardy conditions, enabling them to live through winters when most other breeds would perish. The fleece is very coarse, long, and open, falling from the body in wavy locks. Some Black Faced Highlanders have extremely coarse wool, with more or less hair about the lower thighs. In disposition they are wild and not so easily handled as other breeds. A few of these sheep have been brought to America, but they are not likely to meet with general favor.

The Angora goat derives its name from the district of Angora, in Asia. These goats were first brought to America in 1819, when the Sultan of Turkey presented some to Dr. J. B. Davis, of South Carolina. Large numbers are found to-

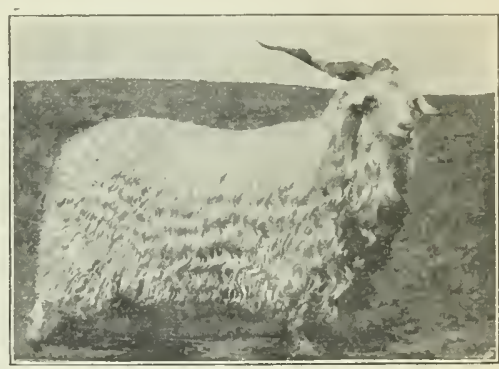

Fig. 53. Angora Goat King Cromwell, owned by R. C. Johnston of Kansas. Photograph from the American Sheep Breeder. day in the United States, espeeially in the far Western and Southwestern states. This breed is smaller than the common goat, individuals usually weighing from 60 to 100 pounds. The color is pure white. The head has a pair of horns which slope backward and curve widely outward, with some twist in those of the buck, but none in the doe's. The ears are large, often six inches long or more, and droop downward slightly. The Angora makes very good mutton, but is not valued for this as much as for its fleece, commereially known as mohair. In fair speeimens this covers the body in silky, wary ringlets, which in a year 
should become about 10 inches long. The fleece ought to show a curl quite to the skin. An arerage weight is about 3 pounds. The better grade of goats produces a mohair that is highly valued for making certain kinds of dress goods, plushes for upholstering work, etc. Angoras have been regarded with faror by some for clearing land of underbrush. They eat the tender twigs and bark, and thus gradually kill the bushes. Goats have been used for this purpose in northern Wisconsin, Michigan, Missouri, and elsewhere.

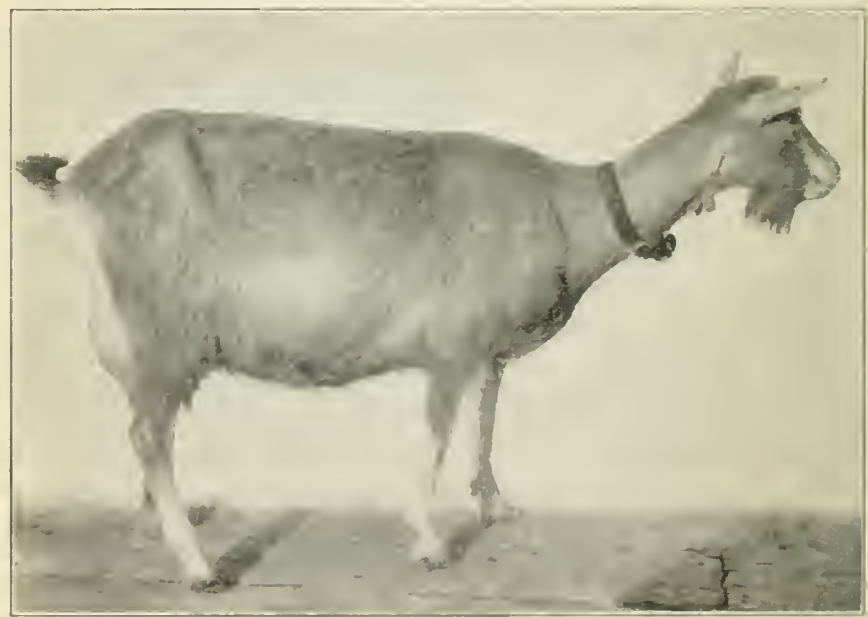

Fig. 54. A Toggenburg milch goat. Photograph from F. Ki. Cooke, of Illinois.

Milch goats are found not only among different breeds developed for milk production, but also among the common goats we are all acquainted with, some of which produce large amounts of milk. There are several breeds in Europe. that have been especially developed for milk production. These include the Maltese goat on the island of Malta in the Mediterranean Sea; the Toggenburg, raised in a valley 
by that name in Switzerland; the Saanan, also a Swiss breed; and several others. The Maltese is one of the best milkers, and may produce three or four quarts a day. This is a hornless goat, usually white in color. The Toggenburg is rated highly as a milker, often producing four or five quarts a day. This breed is medium brown in color, with white stripes down the face. The Saanan is a white or creamycolored goat, and is noted for yielding equally well with the Toggenburg. In Europe goats are milked about six months before drying off. There is some demand for the milk of the goat, because it agrees so well with invalids and children. In regions outside of America where poor people live in large numbers, goats are commonly kept as a source of milk. The people of these countries value them highly, and they mean as much to them as milch cows mean to us.

\section{SOME THINGS YOU MIGHT REMEMBER ABOUT SHEEP}

1. The three classes or groups.

2. How the Merino breed was introduced and promoted in America.

3. Some of the features of Merino wool.

4. Who Ellman and Webb were, and what they did.

5. What the Southdown is valued for today.

6. Why the Shropshire is popular.

7. The origin of the Oxford Down.

8. The color markings of the Southdown, Shropshire, Oxford, and Hampshire.

9. What breeds of mutton sheep have horns in both sexes.

10. Why the head of the Cheviot is attractive.

11. What breed of sheep Bakewell improved.

12. Why mutton from the large breeds is not popular.

13. Where the Lincoln is popular and the prices it brings.

14. What the fleece of the Angora is, and its use. 


\section{SOME OTHER THINGS WORTH KNOWING}

15. What kind of sheep is most common in the state you live in?

16. Who among your friends has the largest flock of pure-bred sheep?

17. How many breeds can you learn of within ten miles of home?

18. As far as you can learn, what is the heaviest fleece produced in your county, and from what breed and sex?

19. Can you get some samples of wool of pure-bred sheep?

20. What kind of sheep exhibit do you have at your state fair? 


\section{CHAPTER V}

\section{THE BREEDS OF SWINE}

The wild hog, or wild boar, as it is usually called, of which there are different forms, is found in widely separated parts of the world. The common wild boar from which the improved breeds of today are descended, has been known in Europe since early historical times. This boar was common in England until the time of Henry II, about 1250. Boar hunting was $a_{0}$ favorite pastime not only with the Romans, but even in the present day, in sections of Germany and eastern Europe, wild boars furnish royal sport. In India these animals are hunted extensively by men on horseback, in a sport called "pig sticking." The wild hog is larger than the

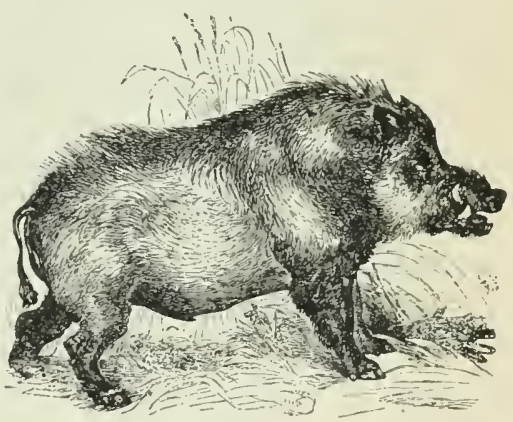

Fig. 55. The Wild Boar. Reproduced from The Hog, by Youatt. domestic one, and is very swift and strong. It is grayishblack in color. The rough skin is covered with short, wooly hair, over which are laid stiff, coarse bristles, especially along the spine. When the boar is angry or excited, these bristles usually stand erect. The head is rather large, long, and rough, and the older animals have short, heavy tusks that curve backward and away from the snout;-and which are used in fighting. The wild hog is native to marshy forests. 
The early forms of the domestic hog were found among the people of several countries, but more especially Great Britain, southern Europe, and China. Domestic swine were kept in herds in England as far back as 863 years before Christ. It is said that in Greece large droves were cared for by swineherds perhaps 3000 years ago. In Italy these animals have long been valued, and the blueskinned, thin-haired, long-legged Neapolitan hog of that country was imported into England perhaps two centuries ago to improve the Berkshire and the coarse white hogs of Great Britain. The Chinese produced a class of white pigs that American and British sailors bought on their travels and brought home, which were used to improve the native stock. Red hogs bred on the west coast of Africa were also brought to America over a century ago, and their blood mingled with our common stock. From this ancestry, after long years of careful breeding, in Great Britain and the United States, have come our present highly improved domestic breeds of swine, of which the following are of interest.

The Berkshire hog is a native of England, and receives its name because of its early development in the county of Berks. This is a region of mild temperature in south-central England, well suited to live stock. The Berkshire was known as a breed late in the eighteenth century. Then it was black, or reddish-brown in color with black or light spots, and had large ears hanging down in front. It was small boned and fattened easily for those times, and frequently. weighed over a thousand pounds. It was improved by the use of Neapolitan and Chinese blood in particular. In the middle of the nineteenth century, when it was considered the best breed in England, the Berkshire was still reddish or sandy-colored, with more or less hlack spots, but was not so large and coarse as those of the previous century. In the 
carly days, Richard Astly and Lord Barrington did much to improve the Berkshire. This hog was first brought to America in 1823 by an English farmer who lived in New Jersey. Soon after others were imported, and since then large numbers of these pigs have been brought to the United States and Canada.

The following are some of the most important features of the Berkshire today. The color is black, with more or less white on the face, feet, and tail. When all four legs, the

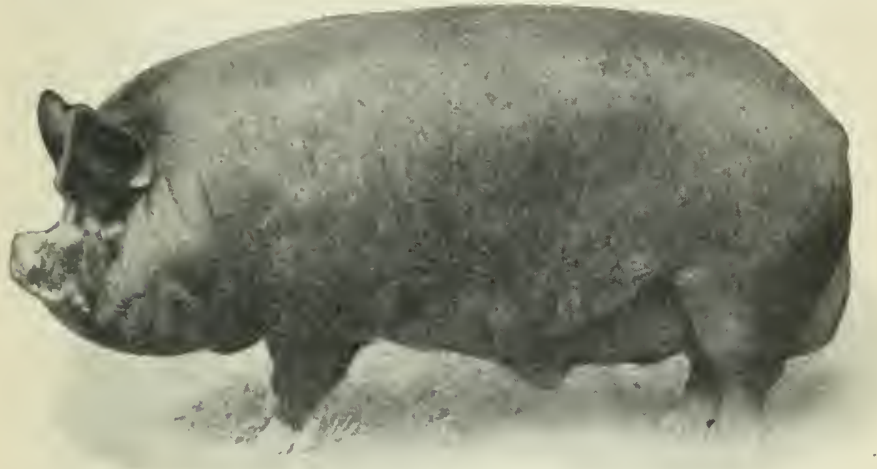

Fig. 56. The champion Berkshire boar at Ohio State Fair 1911. Photograph from Graham Tanner.

faee, and tail are marked thus, they are termed the "six white points." The head is fairly short, the nose slightly curved up or the head "dish faced," as it is termed, and the ears are erect and pointing slightly forward. The head of the Berkshire is one of its most important breed characters. The size is medium to large, mature boars often weighing 500 pounds, and sows about 400 . Oceasionally a boar in show flesh weighs from 700 to 800 pounds.- The Berkshire should have a wide, strong back, but not mueh arched, and 
have a thick, full ham. He should have good legs and bone, and should stand well on his feet. The sows farrow medium-sized litters, averaging about eight pigs.

Berkshires are fair feeders, and mature just moderately well under ordinary conditions. If not fed too much corn, they make a grade of pork that is unsurpassed. In the corn belt of America, with the feed and care given by Western farmers, the Berkshire may be regarded as a lard hog; while if fecl a variety of grain, with corn only a moderate part of the ration, it makes a superior bacon. It has always been a popular breed of swine in England and America, but is not today as extensively kept as the Poland-China or Duroc-Jersey. Yet its merits have long been recognized among the critics of high-class pork. The breed is more widely distributed than any other in North America, being found in about every state and in Canada, and thrives under a wide range of conditions. It is the most popular breed in the East and South. In the West it is in less favor than the Poland-China or Duroc-Jersey.

The Poland-China is an American breed of swine that originated in southwestern Ohio in Butler and Warren counties. This is a rolling country, and produces extensive fields of corn, wheat, and grass. There is no better region in America in which to raise hogs. In that section the early settlers kept large numbers of hogs, fed off their corn, and drove the hogs overland to the Cincinnati market. Different so-called breeds came into Ohio, including the Russian, Byfield, Big China, Irish Grazier, and Berkshire, the latter being taken to the state in 1835. From this mixture, in time came the Poland-China. At first this was a big, coarse, spotted hog, which was rated as a good feeder. The coarseness was gradually reduced, no doubt the Berkshire blood bringing a very great improvement. 
The prominent early breeders of the Poland-China were the Shakers and other farmers in Warren County. John Harkrader did much to improve them, and following him D. M. Magie, of Butler County, no doubt did much for the breed. Pigs of his breeding were widely known at one time as "Magie hogs." During the last half of the nineteenth century there were many noted herds in Ohio, Indiana, and Illinois. Although the Poland-China was long a black and white spotted breed, a change took place in this respect,

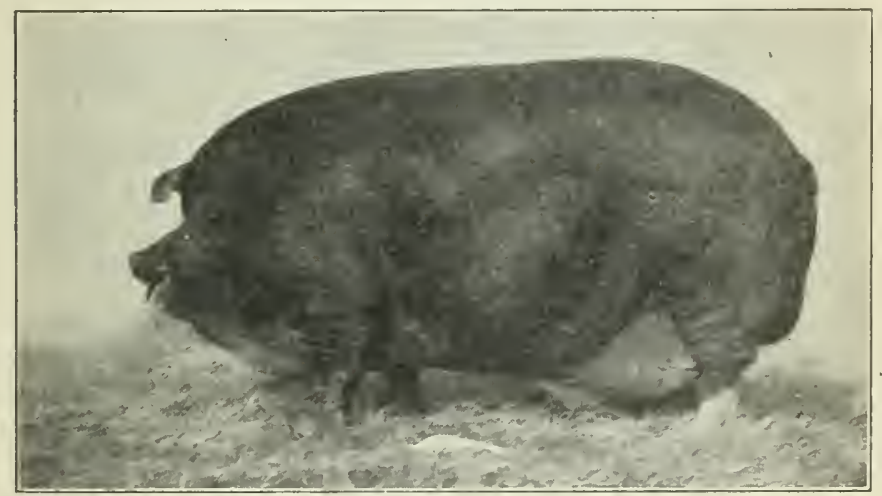

Fig. 57. Globe Perfection, first prize Poland-China boar at Ohio State Fair. Bred by Ed. Klever, of Ohio. Photograph by the author

and black, with a small amount of white, especially on face and feet became popular, and is so today.

In present color markings the Poland-China much resembles the Berkshire. The head is of medium length, and rather straight in the face; the ears, which should be somewhat thin, point forward and then break over to form what is called a lop ear. A good head lacks coarseness, and inclines to be wide between the eyes, and is somewhat short, but is never dished. The body form of this breed is quite 
distinctly its own, the neck being short, the back wide and frequently strongly arched, and the hams highly developed. These features of head, arch of back, and thickness of hams are Poland-China characteristics. The legs are often fine of bone, and incline to be moderately short, the pigs standing just fairly well on their feet. Mature boars often weigh around 500 pounds, and sows 400 pounds. A boar weighing 700 pounds is of large size.

The Poland-China is distinctly of the lard type, and as it puts on fat easily, is noted as a feeder's hog. When well fattened the carcass dresses out well, and is popular with butchers. The pigs often mature too rapidly, not getting as much growth as they should have for their age. Poland-China sows average smaller litters than any of the other common breeds. This has caused considerable unfavorable comment among farmers. It is an excellent grazing breed and will do well on elover or other succulent green pasture. At the present time there is much discussion among Poland-China breeders regarding type, one group preferring a medium-sized, rather fine-boned, tidy type; while another set of men demand what they call "big Polands," which mature into large animals having strong, heavy bone, and make good feeders. The Poland-China has been one of America's most popular breeds, but at the present day it is not in such universal favor. This is due to lack of size or growthfulness, and to the small size of litter. Where well developed, it is one of our most important breeds for the corn belt.

The Duroc-Jersey is a red or sandy-colored breed of swine that no doubt obtained its speeial color markings from the coarse red hog brought from Africa, and from sandy or reddish English hogs, such as the Tamworth and sandy Berkshire. Daniel Webster, of Massachusetts, the famous 
statesman, imported some red hogs from Portugal in 1852, which reached America about the time of his death. In New Jersey large red hogs had been grown for many years, where they became known as Jersey Reds. In New York State another variety of red pigs developed that were called Durocs. They were smaller and finer in bone than the Jersey Reds. The blood of these two families was mingled together, from which was developed what we now call the Duroc-Jersey. The present-day Duroc-Jersey is red in color, of which there

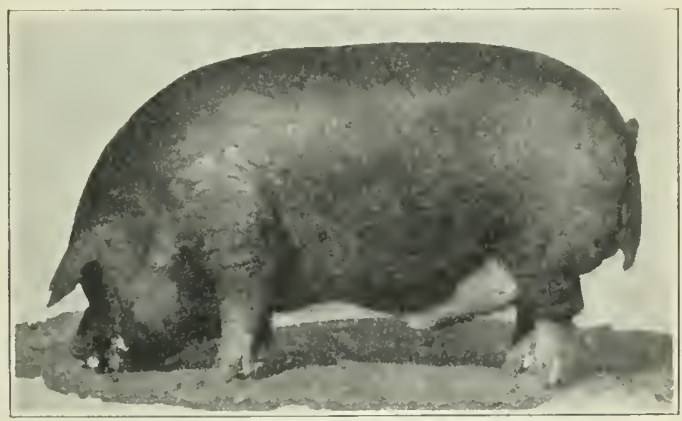

Fig. 58. Good-Enuf-Again, champion Duroc-Jersey boar at Ohio State Fair. Owned by W. H. Robbins, of Ohio. Photograph from owner.

are various shades, ranging from sandy or light red to a cherry color or dark led. A medium red shade is the most popular. The head has a straight face, and the ears lop over forward. The back is usually slightly arched and the ribs are well sprung. The hams do not show quite the thickness of the Poland-China, but are likely to be of good size. The legs earry more bone than do most other breeds, and the hogs stand very well on the feet. The DurocJerseys of a few years ago were inelined to be rather rough, and were frequently heary of shoulder and had creases more 
or less along the sides. They have been greatly improved, however, in recent years. As to size, the boars easily weigh 600 pounds, and the sows 450. Duroc-Jerseys mature fairly early, and finish off in fattening at 200 to 250 pounds, at six months of age. The breed has not thus far made much of a showing in careass test competition. The sows seem capable of having large litters, this being the most prolific of the lard-type breeds. Duroc-Jerseys are produced more especially in the Middle-western states where corn is abundant and where they are very popular. Many herds of Poland-China have given way to the Duroe-Jersey. Ohio, Illinois, and Iowa have more of this breed than any other three states.

The Chester White breed of hogs gets its name from Chester County, Pennsylvania, where it has been bred for a great many years. Claims have been made that the early colonists brought over coarse white pigs to Pennsylvania. In 1820 a Captain Jeffries, of Westchester, Pennsylvania, brought from England some white hogs. Others of the same color also found their way into that section. White hogs were brought to Ohio at an early date, and the Todd family in that state became noted for developing what is known as Todd's Improved Chester White. During the latter part of the nineteenth century, Mr. L. B. Silver, of Ohio, developed a strain of this breed, which is now known as the Ohio Improved Chester White. This is frequently called the O. I. C. hog. All these different families or blood lines, however, represent the same breed, and differ only in minor details. The Chester White, as its name indicates, is white. Oceasionally, small, black spots oeeur on the skin. This is generally the case with all white breeds known in Ameriea. The head rather resembles that of the Poland-China, in that the face is straight and the cars lopped over. The Chester 
White is a true lard type of hog. It is a splendid feeder, anct when well fattened, carries a very broad, arched back and an excellent ham. The quality of bone in the legs is frequently too fine, anch mature animals often stand badly on their feet. The quality of pork is excellent, if one does not object to the large amount of fat. This is one of the large breeds, the O. I. C. hogs weighing very heavy. The usual run of mature

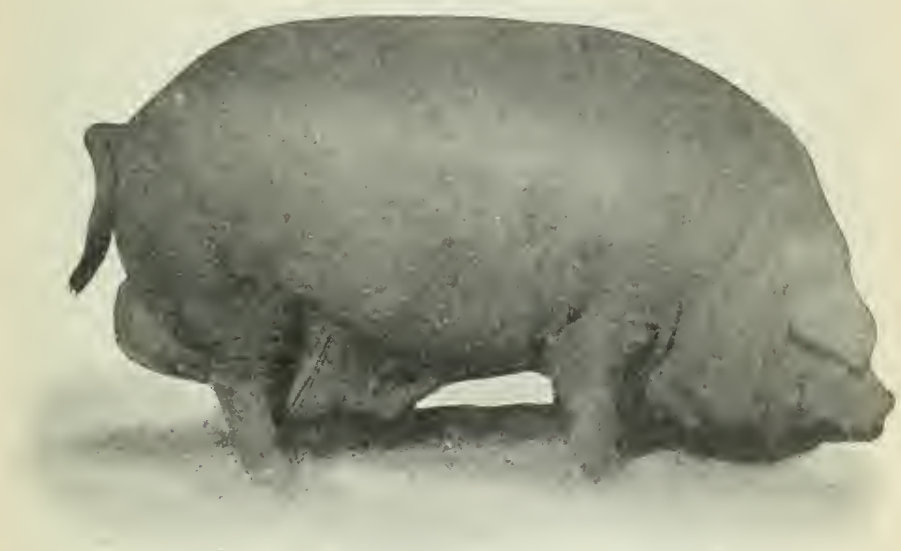

Fig. 59. A Chester White boar. Photograph by the author.

boars will weigh around 600 pounds, and the sows 450 pounds. The sows farrow good-sized litters, the breed ranking close to the Duroc-Jersey in this respect. Sows commonly have nine pigs to the litter. Chester Whites are widely distributed as a breed in the North, and especially east of the Mississippi. In the South any white breed is unpopular on account of color, white hogs blistering under the sun more readily than red or black ones. Ohio and Indiana have many Chester White herds. 
The Large Yorkshire, called in England the "Large White," is one of the oldest breeds of swine. Large, coarse, white hogs were bred in eastern and northeastern England before distinctions of types and breeds were known. English writers of over a century ago refer to these large, slowmaturing, narrow-backed coarse white hogs. They were improved by selection and breeding, and this work was done

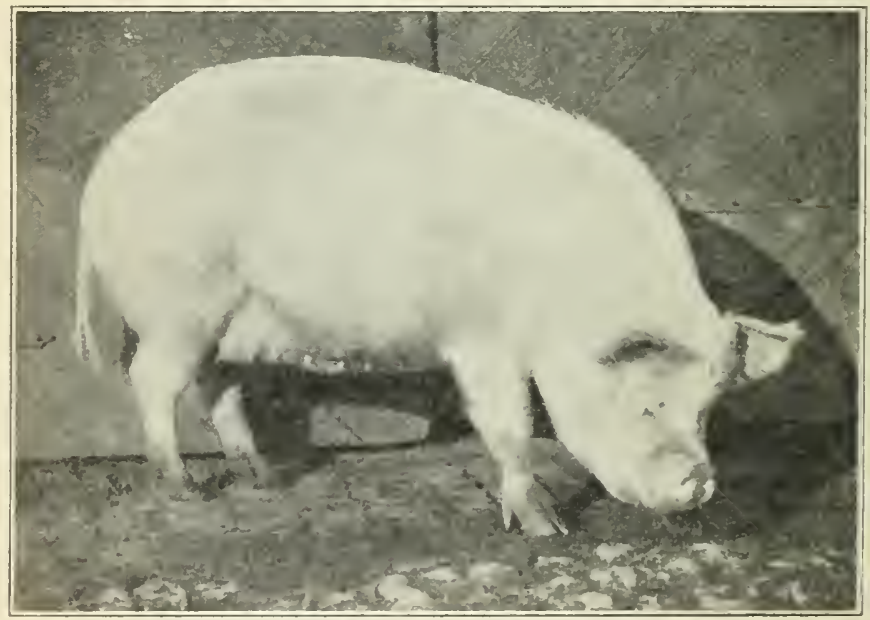

Fig. 60. A large Yorkshire sow, owned by the Ohio State University. Photograph by F. If. Haskett.

in part by factory hands and laborers in the middle of the last century. Joseph Tuley was prominent in this work.

The Large Yorkshire belongs to the bacon elass. As grown today, it is the largest of the breeds. Boars at maturity often weigh 700 pounds or more, and sows 500 pounds. The head inclines to be a trifle long, from an American point of view, and is sometimes slightly dished. The ears should be carried crect, lut with age they usually 
incline forward. The body of the Large Yorkshire should show considerable length and have smooth deep sides, from whieh bacon may be cut to the best advantage. The back lacks the width and the ham the thickness of the lard type. The legs often appear long for the depth of body. Large Yorkshires do not mature early nor fatten and finish off so readily as do hogs of the lard type. They rather tend to eontinue their growth until they have attained considerable size before laying on mueh fat. Even then they will never fatten like our lard hogs, although they will gain as much or more in weight per day. This hog is well adapted for grazing on clover and other green feeds. The quality of the meat is of the very best. More prime bacon is made in Great Britain and Denmark from the Large Yorkshire than from any other breed. The Danes make baeon production a great industry, and they rely on the Large Yorkshire or its grades for this purpose. Large Yorkshire sows are noted for farrowing many pigs in a litter, this being our most prolific breed. On account of its bacon, this is the leading breed in Great Britain and Denmark. In America, these hogs have been bred for a great many years, but have never been popular in comparison with the hogs of the lard type. They are bred in different sections of the North, especially in Canada, and in the Northwestern states.

The Hampshire is a breed of swine that until quite recently was known in seetions of the United States as the "Thin Rind." Where the breed eame from originally, no one knows. It did not come from Hampshire, England, as the American Hampshire Association has claimed, for the English people already have a black breed with this name, while the American Hampshire is black, with a white band about the body. For many years "Thin Rind" hogs were bred in a limited way in Kentucky, southom Indiana, and 
southern Illinois, and these were of the bacon type. Finally the breed was taken up by men in the corn section of Illinois, and it has gradually changed in form to a broader-backed, thicker kind, more nearly of the lard type. This shows what a corn diet will do in changing the form of an animal. Hampshire swine have straight and rather long faces, and the ears vary from erect to leaning forward. The back is of medium width and the body is usually very smooth along the sides. The hams lack fullness, and the legs tend to be somewhat long. The Hampshire is a good feeder, maturing just fairly early, and is gaining in popularity on account of the favor it has with the butcher. In carcass contests, hogs of this breed or its crosses have usually made an excellent showing. The sows also farrow good-sized litters, a much approved characteristic. This is not a large breed, mature boars weighing around 500 pounds, and sows about 300 . The most notable herds are in Ohio, Indiana, Illinois, and Kentucky.

The Tamworth is an old English breed of extreme bacon type. Its native home is central England, where it was known early in the last century. It is red or chestnut in color and of varying shades from very light to dark. In size it is large, the boars often weighing 600 pounds and the sows 450. The head of the Tamworth is undesirably long and straight. The ears at maturity are large and coarse, and lean heavily forward. The body is narrow, the depth of rib is short, the hams lack thickness, and the neck and legs are long. The Tamworth does not fatten easily, and is slow to mature, but produces an exeellent grade of bacon. The sows are prolific, having large litters. There are but few of this breed in cither England or America, for it is not at all popular on either side of the water. There are a few herds 
in the Mississippi Valley, but not enough to attract attention at present.

The Cheshire is a medium-sized, white breed of the lard type, mostly bred in New York State, the place of its origin. The breed originated about 1855, with the Large Yorkshire as an important blood line in the parentage. The Cheshire resembles to quite an extent what the Englishman calls the Middle White, which is really a more compact, broader-

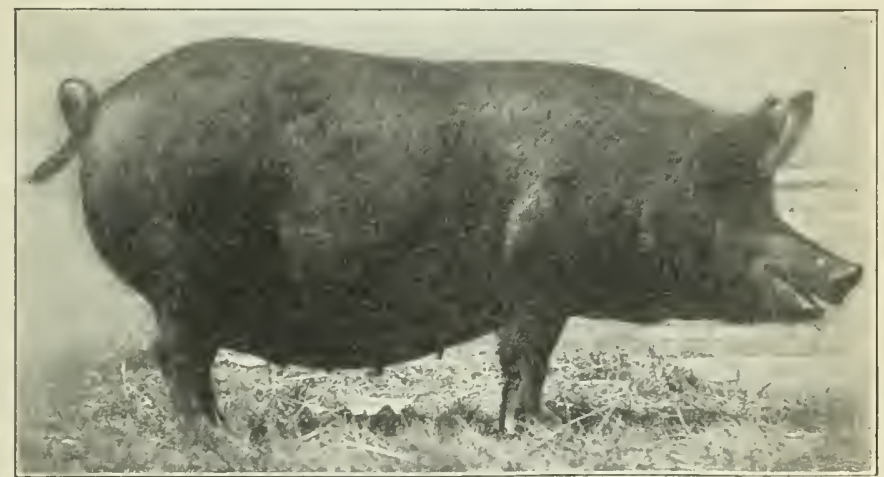

Fig. 61. A Tamworth sow, A first-prize winner at Ohio State Fair. Photograph by the author.

backed, heavier hammen, lardier type than the Large Yorkshire. The Cheshire has a fair size, weighs well, matures early, and feeds and fattens to advantage. The sows farrow good-sized litters in comparison with other breeds. This is one of the least known of American hogs.

The Victoria is a white breed of swine, of which there have been two families, one of New York and the other of Indiana origin. The latter, developed by a Mr. Dyer, is the only one at all known today, and but very few herds of this family are in existence. It is a breed quite comparable in appearance 
to the Cheshire, and is of the lard type. The few herds kept are mainly for show purposes, to win prizes offered at certain fairs where money can be secured without competition.

The Essex is a black breed that originated in eastern England. It is of small size, and fattens very well into an excellent grade of pork. Its principal breed features are the black color, small size, short, slightly dished face, and fine, ercet ears. Today the Essex is almost unknown in America, although at one time it met with a fair amount of faror.

The Small Yorkshire, knorn in England as the "Small White," is of English origin. It was developed early in the nineteenth century, when certain men wished a small, very fat type of pig. This is distinctly a small breed, weighing at maturity about 200 pounds. The head is often short and extremely dished, so much so that easy feeding is impossible. In fancy specimens the head is almost distorted, the ears are erect, the neck short, back very wide, hams short and thick, and legs short. The Small Yorkshire matures early and fattens easily for its size, making a very fat type of pork. The sows are not prolific. The breed has been getting less and less common so that but few are found today in America. In fact there is no demand of commercial importance for it either in this country or abroad.

\section{DO YOU REMEMBER ABOUT}

1. The appearance of the wild boar?

2. How long ago herds of swine were kept in England?

3. When the Berkshire was first brought to America?

4. The size and form of the Berkshire?

5. Where the Poland-China originated?

6. The Poland-China as feeders and breeders? 
7. The origin of the Duroc-Jersey?

S. Who improved the Chester White?

9. The special features of the Large Yorkshire?

10. What change has taken place with the Hampshire?

11. The color markings of each of the four leading breeds?

\section{CAN YOU TELL}

12. What breeds are kept by farmers in your township?

13. Which is the most popular breed in your section?

14. Who has been an exhibitor of pure-bred swine in your county?

15. Whether the breeders of your native state have an important influence in improving the breeds elsewhere?

16. If the swine show at your last county fair was a creditable one? Also at the state fair?

17. Whether improved breeds are kept on any county or state farms in the state in which you live? 


\section{CHAPTER VI}

\section{ANIMAL TYPE AND ITS IMPORTANCE}

Farm animals in early days in America were usually very inferior. The settlers of New England and the older states did not give much attention to live stock. Until we had large cities we had no important live-stock markets. The farmers produced but little more than was needed for the local home sales. In 1830 the first railway was built in America. Before that, people drove live stock long distances to market. As early as 1804, cattle were driven overland from Ohio to Baltimore to find buyers. West of the Mississippi, large herds of cattle and sheep developed with the settlement of the country. There were great drives of cattle and sheep overland to Kansas City, St. Louis, and other places. It was not till 1865 that the Union Stock Yards of Chicago opened for business. Now it is much the largest live-stock market in the world.

The study of animal form in a large way really began with the sclling of stock in the market. At first people were not very partieular. An inerease in population, however, increased the demand for meat. Then men began to buy from the farmer and to sell animals in the markets. These sellers naturally saw certain differenees in their stoek. They saw that some beasts served a given purpose better than others, and that some were really worth more than others for the same purpose. So the men who sold in the markets began to use special words to indicate the kind of stock they were talking alout. 
At first it was only a "good" animal, or a "poor" one. Then other words came into use to show still finer differences. If one looks over the market quotations in the early numbers of the oldest agricultural papers, he will find just such words used in references to the stock. In the course of time, people began to see that farm animals differed in type.

The word type, as applied to live stock refers to the spccial form or purpose of an animal. For example, we say that a horse is of the clraft type. This means that he is large and strong, and especially formed to haul heavy loads. As stockmen use this word, however, it does not mean that the animal referred to is perfect. It is simply an expression that the horse or cow or whatever it may be, belongs to a special group in which we find others of various degrees of merit. The word type has not been used many years by stockmen. At the present time, however, all our farm animals may be separated into fairly distinct, well-known types. The more simple classifications are as follows:
Horses
1. Draft type
2. Coach or carriage type
3. Light harness or speed type
4. Ponies
Cattle
1. Beef type
2. Dairy type
3. Dual or general-purpose type
1. Mutton type
2. Wool or Merino type
1. Lard type
2. Bacon type

All of our farm animals may be sorted, and cach one placed in a group representing one of these types. Each of our breeds of live stock, also, has one or more types. Where there is more than one type in a breed, it is the result of different lines of breeding. At the present time we hear more or less about the American type and the Island type of Jersey; the American type being somewhat larger, coarser, plainer-headed, and less symmetrical in udder than the 
Island type. Some of the more important features that apply to each of the commonly recognized types are briefly stated in the following descriptions. More might be added to each description, but this is not essential at this time.

The draft horse type is massive, showing great power for hauling loads. A horse of this kind should have a large head; thick, strong neck; very broad back; large, deep body; a long, heavily-muscled hind part; a set of four strong-boned, muscular legs, and large, well-formed feet. From a front view, such a horse appears thick through from the breast to the tail. From one side he appears short, deep, and compact of body. The smaller sized draft horse is often termed "chunky," as expressing this compactness. Horses of this type weigh from 1500 pounds upwards.

The coach or carriage horse type lacks the large size of the drafter, and is of more refined appearance. This horse should have a lean, attractive head; a long, graceful neck; a body of medium width and depth, round and nicely turned; long, smooth, well filled out hind parts; and a set of wellmuscled, smooth-boned legs, and first class feet. Good form in this type should show some length and smoothness of outline. Coach horses are valued for their ability to walk or trot with a strong, high-acting gait. Horses of this type should weigh 1250 pounds, though many excellent ones weigh more and some less.

The light harness or speed horse type is well represented in a medium-sized trotting horse. He shows a small, neatlooking head; rather thin, moderately long neek; a narrowness above the shoulders; the body narrow on top, though it should be of good depth; the hind end rather muscular; and the legs small and neat, without much flesh. The entire form shows a muscular development and lightness of limb 
that suggests speed. There is much difference in the size of horses of this type, and weights of 900 to 1100 pounds are common.

The pony type is really that of a small-sized horse. A pony must not stand over 58 inches high. If he does, he is placed in the horse class. There are a number of different kinds of ponies, and among these may be found types corresponding to those of horses already described.

Beef cattle type is rather comparable to the draft type in horses. Cattle of this kind have short, thick necks; very broad backs; (leep bodies; long, wide, thick hind parts; and short legs. The breast is wide, the body thick and deep, and the entire form is compact and smoothly covered with flesh, and well filled out before and behind. Meat production is easily seen to be a feature of this type.

Dairy cattle type is the opposite of the beef sort. The head is placed on a long and muscular neck; the body is narrow over the shoulders; the back is not wide but the body has depth; the hind parts are lean, long, and lacking in flesh; and the legs are small and thinly muscular. Considerable length and narrowness of body; a distinct lack of flesh, making for angularity of form; and a well-developed udder on the female, are special features of this type.

The dual or general-purpose cattle type has certain features between the beef and dairy types. The entire body should be less thick and beefy than the beef form, but yet with a fair amount of thickness. The fact is, if a beef cow has a large, fine, shapely udder, and milks well, she may be classed as a dual-purpose animal, because she combines important features of the other two types. Comparing the males, the dual-purpose type is usually longer and narrower of body and more muscular, and not so thick of outline in front or behind, as is the beef bull. 
The mutton sheep type may be compared to the draft horse and beef cattle types. It is short and thick of neck; wide and level of back; broad and full at chest and at the hind end, and with short, fine-boned legs. A mutton sheep, when fat, is smooth and plump of body, although this smoothness is not usually seen, the body being covered with wool.

The fine-wool sheep or Merino type has been compared to the light harness horse and the dairy cow. Its

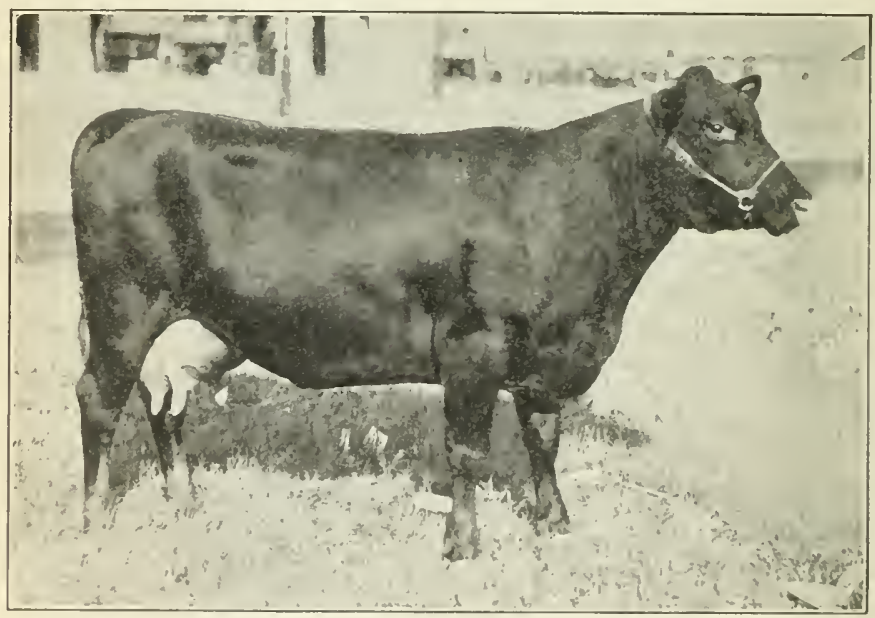

Fig. 62. A dual-purpose cow. Photograph by courtesy The Farmer.

principal purpose is to produce wool. Therefore, we expect to find the body narrow throughout, especially along over the top of the shoulders. This type is muscular, and is rather narrow in front and behind, with thin thighs, lacking the meaty form of the mutton sheep. A fine fleece of wool eovered on the outside with more or less dirtybrown grease, is seen on this type during much of the year. There 
are some fine-wooled sheep that might properly be classed as dual-purpose in type, only not much attempt is being made to establish such a class.

The lard hog type is the one most familiar to Americans. In fair condition of flesh, this hog is noticeable for his compact form, width of back, depth of borly, and thickness from breast to hams. Fattened heavily, these hogs sometimes cause one to wonder how such a weight and wealth of flesh can be supported on four small legs. From this broad, smooth, deeply-covered back may be taken thick layers of fat, from which lard is made. This feature of heavy fat production explains why this is called the lard type.

The bacon hog type impresses one as having considerable length of body, with a narrowness all through, quite in contrast with the lardy sort. This type should have a long, smooth, deep side to the body, for it is from this part that bacon is obtained. As this hog does not fatten so heavily as the lard type, it produces the best kind of meat for bacon, hence is called the bacon type.

The grouping of live stock on the market into classes, was the final result of the development of the modern live-stock trade. As the population grew, the demand for variety and for special purposes increased as never before. There were new uses for horses, and meat animals were sold for a much greater variety of needs than used to be thought possible. So today, we find in the big markets that all types of live stock are grouped into different commercial classes, and then each class is graded according to its merit. For example, here we have the beef type, and within this a number of different classes. One class, known in the larger stock yards as beef cattle, is considered fattened and finished for the butcher, being rearly for killing. Another class, known as stockers and feeders, is sold to go back to the farms for 
further feeding and fattening. Another class, called butcher stock, consists of fat cows and heifers. Then there are various other classes of stock, such as calves, butcher hogs, Western lambs, feeding sheep, etc., all of which are included in the different types described.

The market grades of live stock are also important. Each class is divided into different grades. Beginning with the

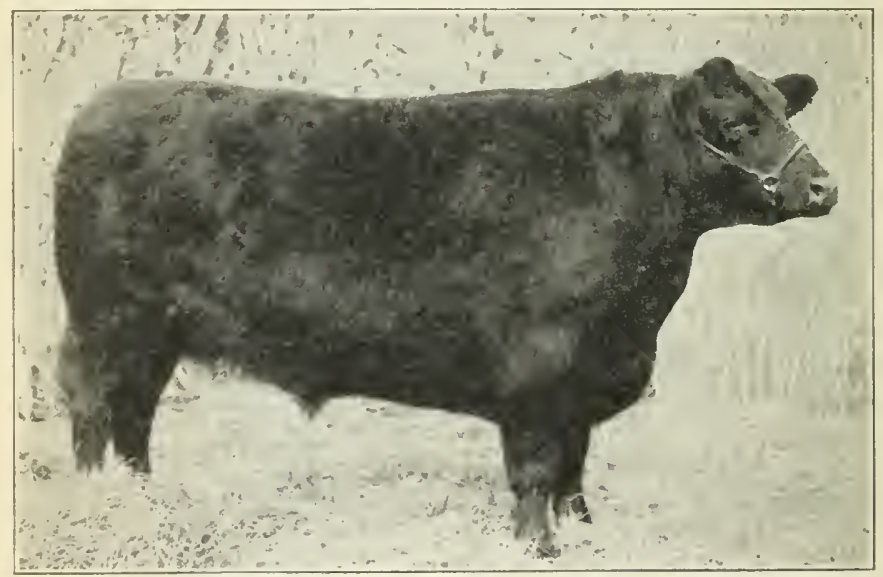

Fig. 63. A type of beef rattle. King Ellsworth, grand-champion steer, 1909 International Live stock Lixposition. Photograph by eourtesy The Farmer.

best and grading toward the poorest, these grades with meat stock in general, in each class, are as follows: prime, choice, good, medium, common, inferior. Some other terms are often used, such as extra prime, good to medium, etc. These words or terms of course are used to express the relative values of animals of the same general clatss. A prime steer, for example, is one with the largest amount of high-priced meat that the buteher thinks will cut out to the best advan- 
tage. So in the prime animal the buyer looks for a wide back, deep body, thick, meaty hind quarters, and a frame entirely covered with a smooth, thick layer of flesh that will cut up well with as little offal as possible. To ensure small waste, an animal must be what we call well-fattened, and have no coarseness or heaviness of bone. As one goes down the line of grades, each of these desirable features is less to be seen. Thus an inferior steer would show a small percentage

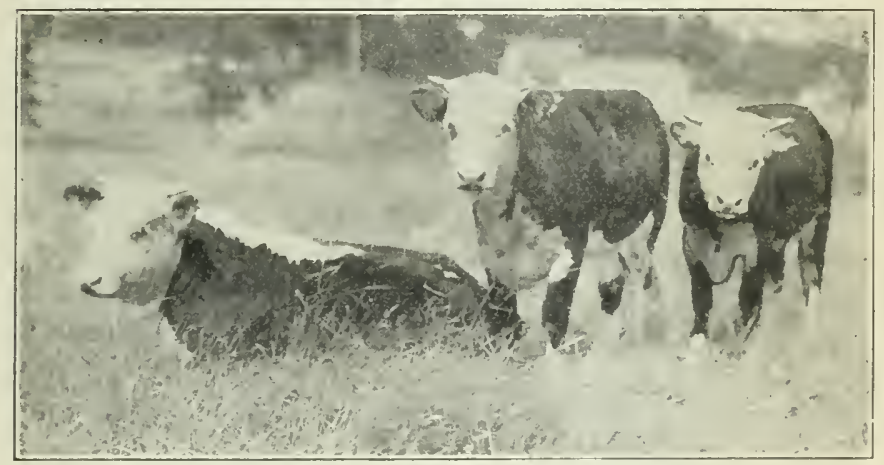

Fig. 64. Feeder ealves of William George, of Illinois. Photograph by courtesy The Farmer.

of high-priced cuts, would lack in condition and quality of flesh, and show much waste at slaughter. These grades have the same relative importance in live stock as similar terms have in grading corn or wheat. For comparison, we have dent corn for one type and sugar corn for another. Dent corn we classify into white and yellow, and then grade each of these as No. 1, No. 2, No. 3, etc., the best being No. 1, comparable to the term prime in live stoek. Put in the form 
of a simple diagram, the relation of classes and grades may be shown as follows:

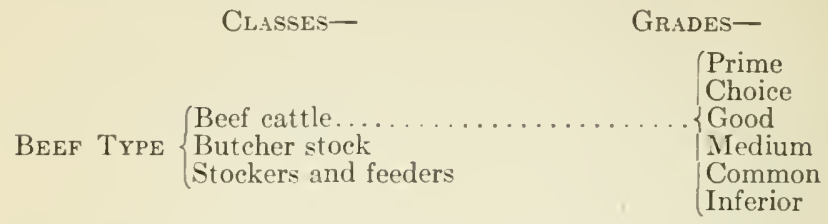

All markets do not have exactly the same classes and grades of stock. The larger a market, the more the dealers divide animals into classes and grades, for the widest demand for different kinds here exist. In the small market not so much attention is paid to the details of class; but the dealers are quick to recognize the merits of a grade. In some markets we find the people more interested in one kind of stock than another. St. Louis is a noted horse market, Buffalo has long been famous for sheep, and Chicago is the great hog center. These large markets, to a certain extent, require other markets, through a live-stock exchange, to classify and grade animals so that selling values are fairly comparable. In small towns without regular markets, merit in an animal is easily scen by men who buy if they have a fair knowledge of type and its meaning.

A knowledge of animal type is necessary if one wishes to understand why some animals serve one purpose and some another. There is a distinct relation of the form of the animal to its special use. The race horse is light of body, narrow but deep of chest, has splendid lung capacity, has slender but strong legs, is very muscular, and is built for speed. The Arab horse, the British Thoroughbred, and the American trotter each has these features well marked, if he is a good specimen of the type. The less he has of these 
qualities, the poorer he is as a race horse. A Merino sheep of the A type is rather narrow of back, long of rib, has short, fine legs, is very muscular, and its entire body, including head and legs, is heavily covered in folds with a fine, oily fleece. This type of sheep is formed to produce wool, and it has very little value for meat. The Merino sheep of Spain, of Australia, or Ohio, if of

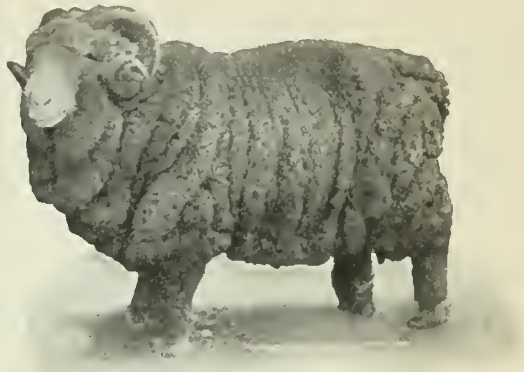

Fig. 65. A Class A Merino ram, owned by S. Blamer \& Son, of Ohio. Photograph from the owners.

the A type, are all much the same kind, and each produces wool of the finest sort. The more the inclination to mutton development, the less fine and heavy is the fleece. The hog best suited to lard production has a short neck, wide back, deep sides, large hams, and short legs; and when well fattened, his body is covered with

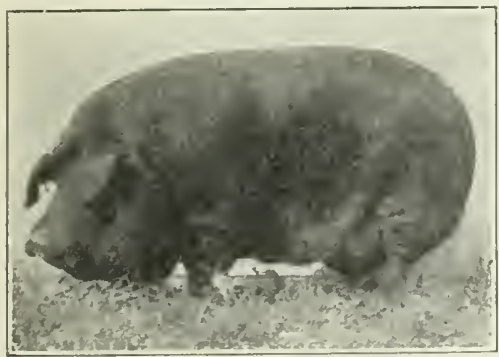

Fig. 66. The fat hog type. a thick layer of fat. This type of hog has been bred in America to produce fat in the extreme. The narrower his back, the longer his head, neck, and legs, the less fat meat will he produce. The race horse, the $\mathrm{Me}-$ rino, and the lard type hog, each has been bred to serve its special purpose. The intelligent stockman can tell at a glance whether the animal he is looking at 
with the thought of purchase is of a desirable type, whether it will command a high place in the market for value, or if its merits are such as to attract no special interest. The animals which most nearly represent the type are fewest in numbers, and bring the highest prices. One reason why we do not have more animals of the better kind is because farmers and stockmen themselves do not know the importance of type. Before one is capable of becoming a highclass breeder or feeder of live stock, he must understand this subject. He must know the relation of animal form to the purpose it will best serve.

\section{AMONG OTHER THINGS, KEEP IN MIND}

1. How they shipped cattle to market in early days.

2. The reason for studying animal form.

3. The meaning of the word "type."

4. The type of a draft horse.

5. For what coach horses are especially valued.

6. The important features of dairy cattle type.

7. The contrast in lard and bacon type.

8. The meaning of commercial classes of stock.

9. The relative importance of the grades of stock.

10. The relationship of form to purpose.

\section{SUPPOSE YOU MAKE THESE OBSERVATIONS}

11. What types of horses do you find on the streets about town?

12. Compare the horses on the farm with which you are best acquainted.

13. What type of horse is most in demand near your home?

14. Learn if horses are shipped to the distant markets from your locality, the priees they bring, and the relation of type to value.

15. Which is the more popular, beef or dairy type in your county, and why?

16. Are there any feeders of stock within your aequaintanee, and if so, what type or types are they feeding?

17. Who is the best live-stoek dealer with whom you are aecuatinted, and why is he the best? 


\section{CHAPTER VII}

\section{REASONS AND METHODS IN JUDGING LIVE STOCK}

The study of the relationship of the form of an animal to purpose or function, is a most important duty of the live-stock student who would know farm animals. The word conformation is used in a general reference to the arrangement of the parts of the form to one another. When one says an animal has a good conformation, he simply means that the different parts are well balanced and in harmony with one another. Scientific study has shown that all animals, no matter how odd they may scem, have conformations best suited to their needs and conditions of life. The giraffe, with excessively long neck, feeds on the twigs and leaves of the trees overhead; the lion, with cat-like form, slyly creeps up and springs upon its prey, and tears and cuts away its flesh by means of its powerful jaws and teeth; the deer, light and most graceful of form, grazes on the grass and tender twigs, and bounds away to safety like a flash, when an enemy appears. Form, size and color, all have their special purposes. Our domestic animals have developed under artificial conditions, over which man has had large control, and this has resulted in our horses, cattle, sheep, and swine becoming creatures of special purpose to a very unusual degree. The great speed of the Thoroughbred, the massive size of the Shire, the excessive milk development of the Holstein-Friesian, and the heavy flece of the Merino, are all fine examples of this specialpurpose development.

The most efficient judge is a student of animal form who at all times can sce and understand clearly this re- 
lationship of form to purpose. The qualified judge obtains his knowledge in two ways: first, by environment or his home surroundings; and second, by education. The average English farmer is a great lover of animals, and is usually a good judge of a beast, and his children inherit the same characteristics. It is second nature for him to measure up in a logical way the weak and strong points in an animal and judge their values. Yet one may become a capable, efficient judge by combination of a natural admiration for animals, with systematic training in judging conformation.

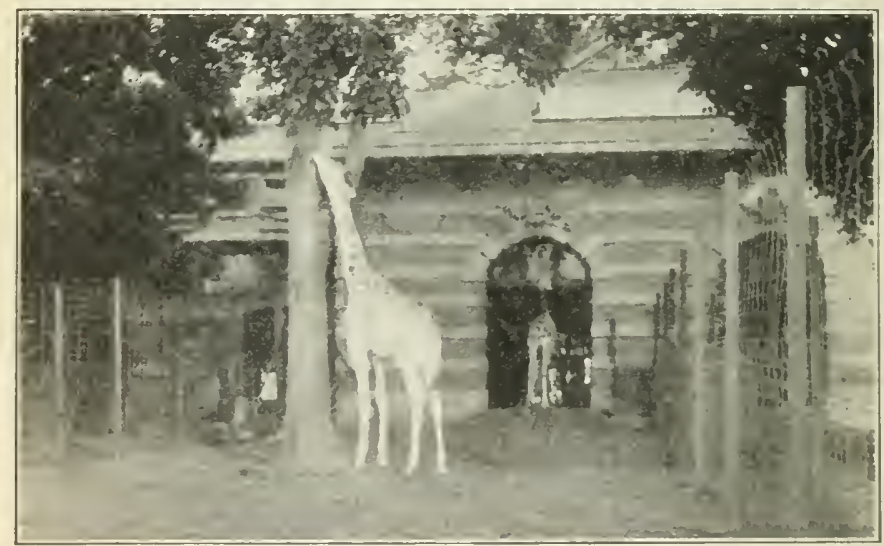

Fig. 67. Giraffes in the New lork Zuological l'ark. Notice one in the doorway. Photograph by the author.

The juelge at all times should be able to compare the animal before him with what he knows to be the ideal or perfect one. The ability to compare differs in degree. Begimners are not supposed to be as proficient as experienced men, yet time and experience add to one's qualifications. Even if one lacks to some extent the desirable qualities to be found in a successful judge, he yet may be qualified to pass 
in judgment on many occasions where the responsibilities are not the greatest.

The judgment of the farmer or stockman should enable him to buy, and to develop his own herd with intelligence. No man is qualified to manage any business at the present day who does not know the difference in the values of the goods he handles. Then why should not the man who owns stock on the farm be capable of judging relative values among his animals? A large number of herds of dairy cattle in the United States have been shown to be unprofitable. This is not as a rule due to the kind and amount of food given, but rather to the kind of animals kept. The man who knows how to select the right kind of dairy. cows to build up a herd, will find his knowledge a source of profit rather than loss, if he makes good use of the same. Without doubt, hundreds of thousands of dairy cows are unprofitable to their owners. This in itself is a good reason why one should study the relation of form to production.

Some animals have important defects that will be noticed only by men who are capable judges. The man who knows nothing of a horse and desires to purchase, if he depends on his own judgment, is liable to buy something he does not want. A side bone or a spavin may be a little thing to see, but its presence on the horse is a distinct imperfection, as one will quickly learn if he tries to sell such an animal. A good judge will discover these imperfections and let another be the purchaser. On every hand men who have given no serious study to qualify themselves for this work are engaged in buying live stock.

Some experts make a specialty of buying immature or green animals that give promise of great development. Such men are keen students of animal form. It is not difficult to pass on the merits of a mature horse that stands 
before one in perfeet eondition, ready for the show ring. It is not so easy a matter, however, to go into the pasture and select the best prospect from a buneh of thin yearlings that have had no special eare during the warm, dry summer days. The man who goes to the stock-yards to buy a lot of steers for feeding is at the merey of the dealers there, unless he has the necessary judgment, not only to know what kind of cattle he wants, but how to sort them out. The ability to select wisely the green, untrained colt or promising heifer has enabled more than one man to find what we sometimes call "a diamond in the rough."

The greater the number of qualified judges in a community, the better will be the general average of the animals there, and the more valuable from a eommereial standpoint. An example of this is seen in England, where good judges of stock are comparatively common. It is interesting to observe, not only that the flocks and herds of that country are much superior to those of any other eountry, but that the people of the rest of the world for generations have been sending their gold to England to exchange for superior stock. Most of our improved breeds eame from Great Britain, and we sent there for them beeause their merit was seen and appreciated. Suppose the people of Minnesota, for example, were to give special attention to the improvement of their live stock, and the study of animal form became popular, what would result? Would there not be a great improvement in the live stock of the state, and would not the wealth of Minnesota be thereby greatly inereased?' It most certainly would.

A natural interest in farm animals and a love for them are also good reasons for making a careful study of them. The greater the intelligenee with which one can look an animal orer, the more pleasure he will find in the oceupa- 
tion. No business that offers no incentive to greater effort profits a man much. The production of beautiful and useful animals can not but bring out the best there is in a man's character; while at the same time he is rendering a service to his fellow man by producing something that adds to the wealth of the community. We call a man a great artist who paints on canvas a beautiful picture of a magnificent horse, but what shall we say of the man who bred and raised this horse to his perfect state? Is he not the greater artist of the two?

The use of the scale of points, or score card, as it is often called, is a first step in the systematic education of the person who desires to learn how to judge live stock. The scale of points was first originated in 1834, on the Island of Jersey, as has been stated in the Jersey section of the chapter on cattle. Some of the people on the island felt that something should be done to improve their cattle. So they selected two cows, one of which they thought had the nearest perfect form in the front half of the body, while the other was considered to have a perfect rear half. Then they placed a numerical value on each of these best halves of the body, using these two cows to furnish a standard or model with which to judge other cows. They also selected two bulls, and made a score card for the males by the same process. As a result of this unique method, "A scale of points for Jersey cows," as it was called, gare the cows 27 points; and another scale gave the bulls, and the heifers not in milk, 25 points. The people on Jersey made a practical application of the use of the scale by comparing their cattle with those standards. The people derived much benefit from this method of judging, and their cattle were gradually improved. They revised this scale on several occasions, and among other things finally adopted a uniform standard of 100 points for each sex. 
Since that time score cards have been much used by men interested in other kinds of stock, and seales of points have been adopted for many of our improved breeds. Not only that, but score cards that apply only to types of stock, such as the draft horse, etc., are commonly used in agricultural schools and colleges. The following is a copy of a score card for Dorset Horn sheep, that was adopted many years ago. It is given here on account of its concise form and simplicity of expression.

The Dorset Horn Sheep Scale of Points

\begin{tabular}{|c|c|c|}
\hline Points scored & $\begin{array}{c}\text { Perfect } \\
\text { score }\end{array}$ & $\begin{array}{c}\text { Score } \\
\text { of } \\
\text { animal }\end{array}$ \\
\hline 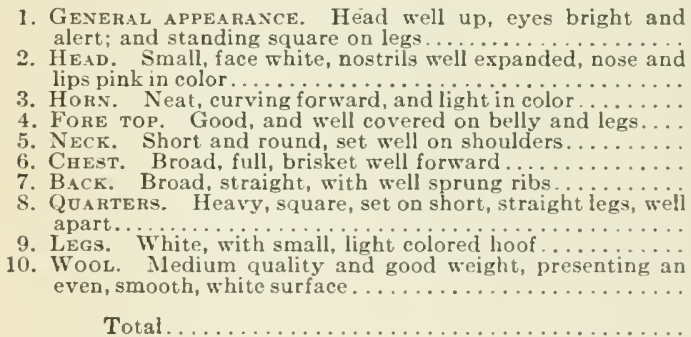 & $\begin{array}{r}20 \\
5 \\
10 \\
10 \\
5 \\
10 \\
15 \\
10 \\
5 \\
10 \\
100\end{array}$ & \\
\hline
\end{tabular}

An example of the use of a scale of points is necessary, and this of the Dorset will serve our purpose. Under "Points scored," it will be seen that there are ten things to which attention is directed. Each of these ten is given a brief description and a number, which represents what the stockman calls "points." The number 20 in the column named "Perfect score" means that a Dorset sheep that would exactly answer to the description of general appearance there given would score 20 , or would be perfect in this one respect. If in scoring a sheep one found that in his opinion each part was perfect, then he should give the full value in the blank space for "score of animal." In sueh a 
case the sheep would score 100, and hence by the scale of points would be perfect. But we have no such animal. It is rarely that one will score 90 points or above, and but few grade as high even as 80. Suppose you were scoring a Dorset ram. As you examine the animal, you are sure to find him inferior to perfection in some points. He may carry his head perfectly, the eye may be above criticism, but you may find good reason to criticise the way he stands on his feet. He may not be bad in this respect; so you give him 17 points for general appearance instead of 20. Narrow chests are very eommon, and our Dorset may show by the close way his front legs are placed together, that he lacks a broad, full chest; so after consideration you give him 7.5 points for this part, which you think is all the credit he should receive. Thus one goes through the list of points and examines the animal systematically and critically, putting down the score from part to part, finally adding the column made, and so getting the total points scored for comparison with the perfect Dorset.

The value of the score card lesson is seen in several ways. It trains the student to examine the animal systematically, and impresses on the mind the things that should be considered in studying form and character. Attention is first called to the animal as a whole, when character is considered, as it can be studied at no better time, and then the different parts in proper order are carefully examined and rated. So one learns to make first a general examination, to get the balance of parts, the breed character, the size, quality, and condition, and thus męasure up the entire animal from the standpoint of appearance. Then comes the detailed study of the head, next the neck, then the breast, and so on. The relationship of each part to the other must be considered so as to get a fair idea of the strong and weak points in the 
conformation. Thus systematic study becomes a feature in the use of score cards.

The relative value of the parts is also shown in the use of the score card. When a specimen of a breed is being studied, we must remember that we are using a scale of points that has probably been adopted, after much careful study and comparison, by a committce of experienced men most familiar with that breed. Thus we get the best measure possible of this breed, and in the scale we learn what parts are most highly regarded, and which least. If we are using a score card such as relates to a fat hog, where breed is not considered, such as is in common use in the agricultural schools, then we find that experts have made this up so as to give the proper values to the different parts of the body. No matter what kind of score card we are using, we may be quite sure that it will give a recognized place and value to each part or group of parts. The various breeds of live stock of much the same type have scales of points that place similar values on what may be called their most important characters. For example, all the clairy eattle score carcls give many points to udder, ete., while those of beef cattle give spccial credit for breadth and thickness of back.

In the use of figures in scoring, it is not well to grade any part in too fine a degrce. Suppose the ear is given one point. When so small a number is used to indicate perfection, grades of .25 or .50 or .75 may be used to express the score for that part, and .25 of one per cent is small enough to enable one to express reasonably accurate valuation of the ear. In any event, decimals should be used, and the person scoring should have his column of figures properly arranged, with the decimal points in line. When common fractions 
are used, the column of figures do not stand out so clearly in contrast as when decimal fractions are used.

The number of points cut is an expression sometimes used when referring to the number of points deducted from perfection. If a part in the perfect score is credited with 10, and one gives the animal in question 7 points, then we say it has been eut 3 points. Some young judges often write the 3 on the card, instead of the 7. This is wrong. The points cut should not be written down.

The value of the score of an animal should not be regarded too highly. The chief importance of the score card lies in the first lessons in judging, in which the different parts of the animal, their location and relative value are impressed on the mind. However, it is difficult to score an animal satisfactorily under the varying conditions of living flesh. Today we may score an animal 75, and tomorrow perhaps 71 . The horse we scored yesterday may show more character and style today than he did 24 hours ago. We do not know how to express in cold figures these things we see in the beast before us. We can tell what we see, and if we have two or more animals before us for judgment, it may be an easy thing to place them in their relative order of merit, and with good reasons. Yet these reasons can not be so clearly shown by a column of figures on a score card. On various occasions efforts have been made to judge animals on the basis of the seale of points, and to make show-ring awards accordingly. This plan has been carefully tried by many of our best judges, and has very generally proved unsatisfactory, and for the reason given. Today the scoring method is generally discarded, except at poultry shows, and here it has given such dissatisfaction that it has been abolished in many cases. In spite of this criticism, we must not lose 
sight of the value of the scale of points as a standard, and what it may teach.

Judging by comparison is the next step to be taken after a few lessons with the score card. This means keeping in one's mind the essential features of the scale of points, and then studying one or more animals of a kind and placing mental values on the subject or subjects examined. A person should make himself familiar with the different types or breeds that he is interested in, and at every opportunity give personal study to individual animals. In a matter of comparison, it is necessary to keep in mind the impcrtant features to be considered, and then judge the animals as intelligently as possible. In judging by comparison, it is customary to line up the horses or cattle or sheep side by side, so that they will face in the same direction. Hogs are usually examined in small groups, being kept together with the help of hurdles.* The front feet should stand slightly higher than the hind feet, and there should be space enough for the judge to pass easily between the animals to make his inspection. The center of an open space, with a firm, clean floor, is most desirable.

When the heads are lined up, the other parts are in the best positions for inspection. The judge then begins his comparison, first walking around the line of animals and noting from different points of view the general comparison of one with another. The judge must necessarily place first in rank the animal that shows the most breed or type character, that has the most complete balance of parts, the most perfection in various details, and the least number of faults. Emphasis, however, must be placed on the special purpose of the animal under consideration, as weight in heary draft

* I hurdle is similar to a small section of a light panel fence. Some hurdles weigh only 3 or 4 pounds and are easily handled. Others may be longer and beavier, requiring two men to handle. 
horses, udder development with dairy eows, or charaeter of fleece with Merino sheep. For example, most of the scales of points of the breeds of dairy cattle devote about $1 / 3$ of the total seale emphasizing the size, form, ete., of the udder, teats, milk veins, and wells. Such special features must be kept in mind.

In placing the animals, it becomes a question of prompt decision in sorting out and getting the individuals in one, two, three order of relative merit. In large rings at live

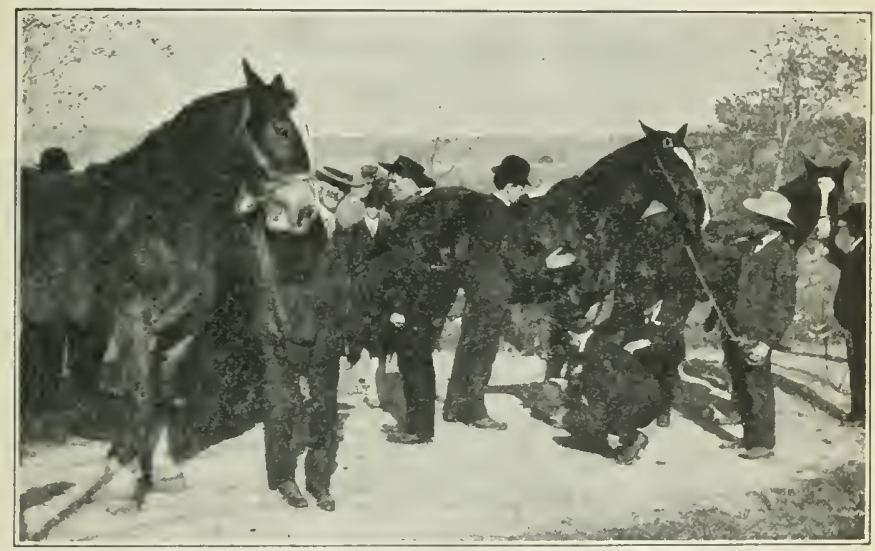

Fig. 65. Students judging a ring of horses by comparison. Photograph by author.

stock shows, judges often divide the animals into two groups, those that they consider worthy candidates for the prize list, and those that are not. The former group is frequently referred to as "the short leet," a British expression for the choicer individuals. After the short leet is selected, the other group is usually sent to the stalls. In most comparative rings, it is not diffieult to find quickly the best animal; but as one deals with the stock farther down the line, 
it becomes neccssary to decide on the relative demerits rather than the merits of each, and to place highest those that show the fewest undesirable features, a matter in which judges sometimes differ quite a bit. Naturally we do not all see things alike; and so the judge who does his work carefully and comes to a decision independently of the views of others, is assuming his responsibility in the right way.

Keeping notes on animals under comparison is a very good plan. It is customary in classes of stock judged by students, to give each animal a number or letter. These marks may be written on common gummed paper labels, and stuck on the rump. Then on a small card or folded slip of paper, one may give space to each animal under its number, and make brief notes of eertain features of importance. These notes are often instructive and suggestive, and aid the young judge in keeping things in mind. In the student's judging contests of today, the boys are allowed to take notes in this way, and use them for reference up to the time of appearing before the judges to give their reasons.

In discussing an animal being judged, it is desirable to do so briefly and clearly, emphasizing the important things, such as character, general conformation, quality, back, body capacity, chest development, or hind quarters. Much, of course, will depend on the spccial case in hand. Then if one is describing an animal, or is comparing two or more, the frequent use of such expressions as "he has a good back," or "she has the best quality," are to be discouraged. The words good or best in these cases really eonvey no specific information. Instead, if one says, "He has a long, wide, muscular back;" or "She excels the other in quality, as seen in a fine, silky coat of hair and a mellow, elastic skin," then the reasons given will be clearer and convey more meaning than simply "good" and "best." 
The decision of the judge is always open to criticism. Being only human, we see things from different points of view; so why should we not differ? The courts do not all agree; as is often seen, one court reversing the decision of another. Two things, however, on the part of a judge are most important, one is honesty; the other is knowledge of his business. If one has these qualifications, and then comes to his decisions with independence, regardless of what anyone else thinks, his work as a judge will as a rule be satisfactory and his judgments will command respect.

\section{BY THE WAY, DO YOU RECALL}

1. The meaning of the word conformation?

2. Why one man is a good judge and another is not?

3. The advantage that has come to England from having many good judges of live stock?

4. The condition under which the scale of points originated?

5. The general application of the scale of points?

6. How figures should be used in scoring?

7. The chief importance of the score card?

8 . What is meant by judging by comparison?

9. What to emphasize in judging dairy cattle?

10. The most desirable method of discussing animal form?

11. Some desirable qualifications for a judge?

\section{WOULD IT NOT INTEREST YOU TO KNOW}

12. Who are the most intelligent judges in your county?

13. Who some of the judges were at your State Fair?

14. Who judges grade and cross-bred fat cattle at the International Live Stock Exposition?

15. On what basis men are selected as judges, especially at county fairs? 


\section{CHAPTER VIII \\ THE POINTS OF THE HORSE}

The exterior parts of the horse are referred to by horsemen in terms not familiar to all. In order to judge intelligently and to use the score card, one should know the location and importance of these special parts. The accompanying illustration makes the location of many of these clear. Without going into too much detail, the following is given regarding some of the points least understood.

The ears should be fine and not large for the animal, and be moderately close together. They should be carried in an alert, pleasing manner, indieating good disposition.

The poll is the top of the skull just back of the ears.

The forehead is the space below the ears and above the eyes. A prominent forehead indicates intelligence.

The cheek is the large flat side of the lower jaw.

The nose is the more prominent part between eyes and nostrils. A wide nose goes with full breathing capacity.

The muzzle includes the nostrils and mouth. Good feeders and animals of strong constitution usually have comparatively large muzzles.

The lower jaw should be wide and strong. A narrow jaw bespeaks a weak conformation and inferior feeding eharacter.

The crest is the curved line of the neck from the poll to the withers. Males should show some crest, but on the females this feature is not prominent. Stallions frequently have a thick, muscular neek, with a strong erest. This is a sign of masculinity, and is objectionable on mares. 
The throat latch is the part where the head and neck join on the lower side. Fullness and heaviness here are objectionable, indicating lack of freedom in breathing.

The shoulders extend from the side of the breast, sloping nearly to the top of the back. The upper portion of the

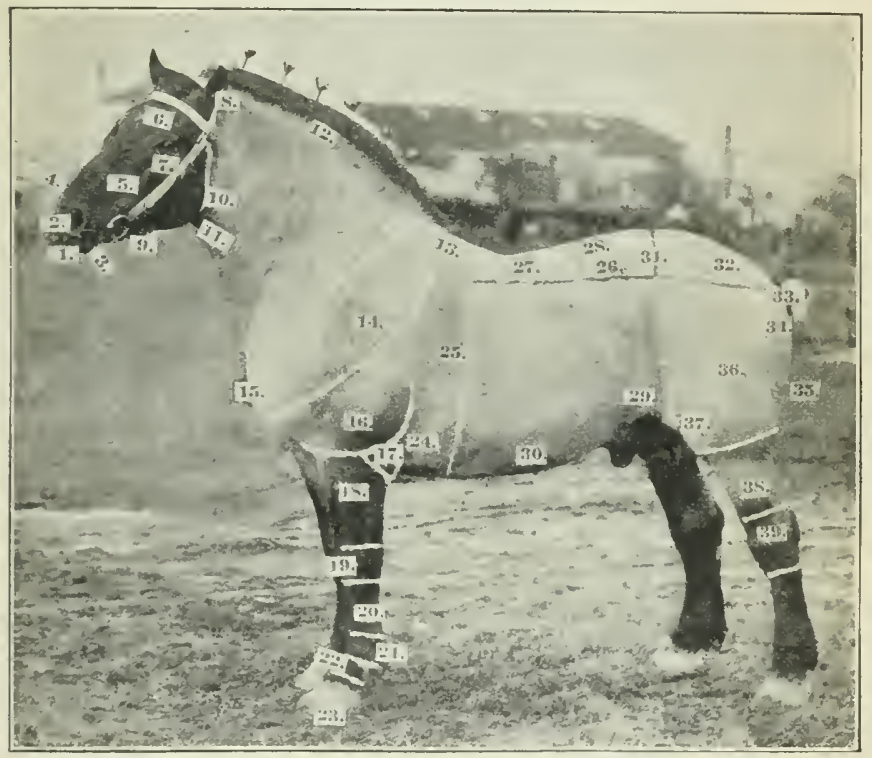

Fig. 69. The Points of the Horse.
1. Mouth.
2. Nostril.
3. Chin.
4. Nose.
5. Face.
6. Forehead.
7. Eye.
8. Ear.
9. Lower jaw."
10. Throat latch.
11. Windpipe.
12. Crest.
13. Withers.

14. Shoulders.

15. Breast.

16. Arm.

17. Elbow.

18. Forearm.

19. Knee.

20. Cannon.

21. Fetlock joint.

22. Pastern.

23. Foot

24. Forefiank.

25. Heart girth.

26. Coupling.
27. Back.

28. Loin.

29. Rear flank.

30. Belly.

31. Hip.

32. Croup or rump.

33. Tail.

34. Buttocks.

35. Quarters.

36. Thigh.

37. Stifle

38. Gaskin.

39. Hock. 
shoulder blade is wide and flat, and should be smoothly laid into the body. Muscles are attached to the shoulder blades and play an important part in ease of motion. A long, sloping, well laid-in shoulder gives the easiest and fastest motion.

The withers, the crested, bony prominence between the shoulder tops, is the name given to the spine at this point.

The arm is the wider, more muscular part just below the shoulder. The width and covering of muscle indicate its strength.

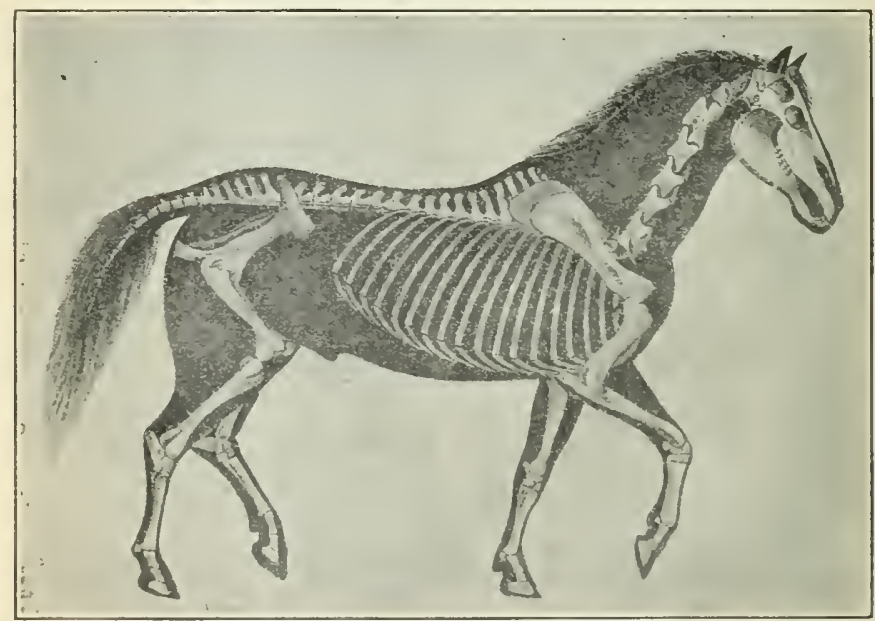

liig. 70. The position of the skeleton of the horse within the body. Reproduced from "Diseases of the llorse," $U$. S. Department of Agriculture.

The forearm lies just below the arm and extends to the knee, and should be long and broadly muscular. A thin, narrow forearm is a weak conformation.

The knee should be broad in front, straight in position as viewed from in front, should have a good depth, and be well supported below. 
The cannon bone reaches to the joint above the foot, and consists of a round-fronted bone, with two small bones back of it. There are two tendons lying directly back of the cannon bone. The correct shape for the cannon bone is short and somewhat flat, an important feature of a strong conformation. It is especially desirable that the bone below the knee be wide, furnishing a strong support for the knee.

The fetlock joint connects with the lower end of the cannon bone. This joint should be straight, deep through, and smooth.

The pastern is in the main a combination of two short bones, and should stand at an incline, because it plays an important part in breaking the concussion which takes place when the horse is in motion. The shorter and more upright the pastern the more liable is the horse to have bone diseases and a hard gait. Carriage horses should have the pastern show a slope of about 45 degrees. Drafters are usually steeper of pastern than the light horse. The pastern is sometimes too long, and lacks the strength to support the body correctly.

The foot consists of several parts. The hoof proper is a very tough, horny bone, and in form should be rather round, although the hind foot is never as round as is the one in front. The top of the hoof should not be narrow and small, but should have some fullness compared with the lower part. The back part of the hoof makes a sudden turn forward underneath, forming a $\mathrm{V}$-shaped portion known as the frog. This frog is somewhat elastic, and acts as a buffer on the surface of the ground, which under natural conditions it should just touch. The frog should never be pared by the blacksmith, excepting to remove tag ends or parts grown out of shape. A good frog saves the foot hard punishment on the road. The sole of the foot is the part between the outer 
wall of the hoof and the frog. This part is slightly concave or arched. The entire back part of the hoof is called the heel, and this should be neither low nor high, having only

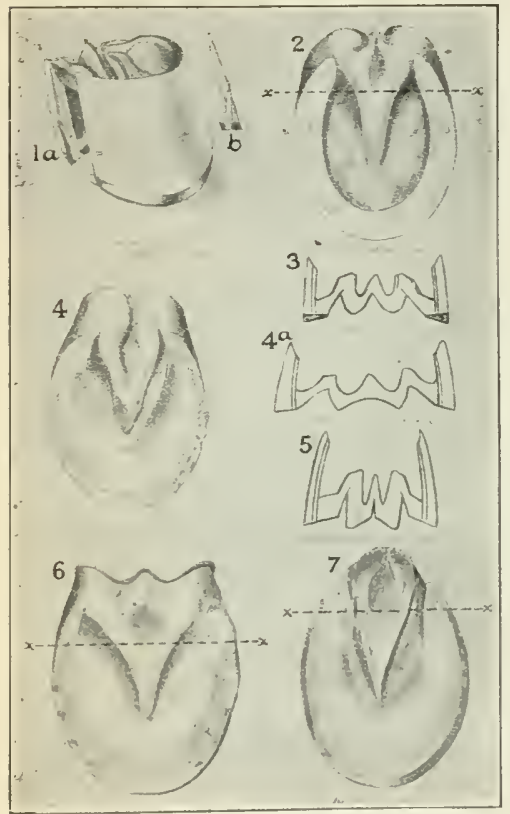

Fig. 71. THE FOOT OF THE HORSE.

1. (a) Nail properly driven; (b) improperly driven.

2. I sound foot.

3. A section across 2 at $\mathrm{X}$.

4. A contraeted foot.

4a. 1 seetion across 6 at $\mathrm{X}$.

5. A section aeross 7 at $\mathrm{X}$.

6. A sound but flat hoof.

7. A badly contracted font.

Reproduced from Special Report on "Diseases of the Horse." U.S. Dept. of Agriculture, Plate $34,1890$. enough height above the ground to give the foot strength and protection. The heel should have about the same slope as the front part of the hoof, which is about 45 to 50 degrees. The hoof should be free of cracks and not be brittle, defects that are all too common. Most people prefer a dark-colored hoof, believing it tougher and less liable to break than a white one.

The heart girth or chest is the circumference of the body just back of the shoulders. A deep, full chest indicates vigor and constitution. A depression back of the shoulders shows lack of room for those vital organs, the heart and lungs.

The back should be straight and short, with the ribs widely arched.

A considerable depression or sag of the back is a sign of weakness. The back extends from the lower end of the 
withers to a wide, somewhat level part called the loin.

The loin is the broadest and flattest part of the back, and lies between the last rib and the point of the hips. The strength of back lies in the loin, which should be short, wide, and heavily muscled. A long, narrow loin is a sign of weakness and inability to stand up under severe work.

The coupling is the space between the point of hip and the last rib. A short eoupling indieates endurance.

The hip is seen as a point more or less prominent on each side, just back of the coupling. The hips on mature females are usually more prominent than on the males. Symmetry of form ealls for the hip to be nieely laid in, with a smooth covering of flesh. There are other good reasons for not having a wide placing of the points of the hips, which need not be discussed here.

The croup, or rump, is the long, museular development from the point of the hips to the setting on of tail. Great power and strength exist here, and so it is important that this part be long, wide, and fairly level. A steep rump is unsightly, and a narrow one has less muscle than a wide one equally long. Length here is also desirable as affecting speed.

The thigh extends from the rump down to the large joint below, known as the hoek. This part should be very muscular, and wide from the lower side of the croup to a joint below ealled the stifle. The upper part of the thigh is wide, while the lower portion, often termed the gaskin, is long, narrow, and very muscular. From the point of the hip to the hock one should look for eonsiderable length.

The stifle joint is loeated in the front part of the thigh close to the body. This is comparable to the knee in the human skeleton. Some of the strongest muscles of the upper thigh are connected with this joint by means of tendons. 
The flanks refer to the parts where the legs join with the body. The front flank is just back of the arm, while the hind flank is the high part of the side above and beyond the stifle. A low, full flank goes with large body capacity and constitutional vigor. Horses high in the flanks usually appear long of leg.

The hock is the large joint about half way down the hind leg. This is a very important part, and should be wide in front, deep through from front to rear, and should be lean rather than fleshy. Large, heary horses tend to have what are known as thick, meaty hocks. There are small bones in this joint, and they are most important in reducing the concussion which comes from the severe use thrown on the hind legs when in action.

The general features of the cannon, fetlock joint, pastern, and foot in the front legs are essentially the same as those behind. However, the rear cannon bone is flatter and deeper from front to rear, and usually shows somewhat more length. The hind pasterns also are usually less sloping than those in front.

The position of the horse at rest should show the feet squarely placed, and the legs as perpendicular as possible, as indicated by the position of the camnon bones. Horses' legs may take a variety of positions. Sometimes they toe in, or perhaps toe out. In such cases the legs are not straight. If the hocks nearly touch, then the hind feet usually point out; while if there is considerable width between the hocks, then the toes point in. A wide or bowed hock shows a very weak conformation, worse than one that is too close. Horsemen prefer the hocks to come close together rather than to be spread wide apart, for the closer position gives a better hock action. 
The horse at the walk should follow a straight line on being led, not swinging the body to one side. The feet should be raised with snap, and carried forward and upward, and the knee and hock flexed, as it is termed. In this flexing movement, the foot describes a half circle before it strikes the ground. Heavy horses tend to swing the feet to one side, or paddle or wing, as it is sometimes called. When

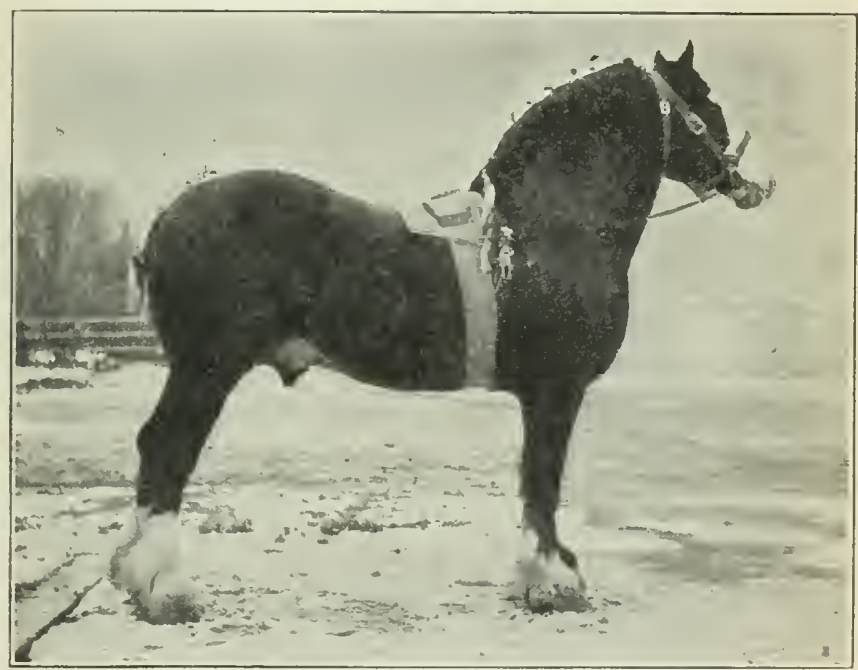

Fig. 72. A good attitude, and correct position of legs. Photograph by courtesy The Farmer.

the feet in motion come too close together, the horse is said to "interfere," that is, the hoof of one foot will strike the ankle of another and may cause lameness. As the foot is raised, a person standing behind a horse in motion should be able to see the glisten of the shoe and note the carriage of the foot. 
The movement of the feet in the trot is such that diagonally opposite ones are moved in the same direction; that is, the front right and left hind feet move forward together. The trot is known as a diagonal gait.

The movement of the feet in the pace shows the two legs on one side of the body in like motion at the same time. The pace is a side gait, and pacing horses are sometimes called "side-wheelers."

The action of the horse is highly valucd. A heavy draft horse that has a rapid and true walk will accomplish much more work than will the horse of slow movement. A fast trot is not necessary with the heary horse; but when moving faster than a walk, a horse should carry his legs with spirit and ease. A premium is always placed on the action of the carriage horse for the city coach trade, high knee and hock action being especially valued. The roadster or trotter of first class must have a long, active, true stride, such as always goes with superior speed.

Quality in the horse is shown in the hair, the skin and bone, and in the general appearance. A fine, silky coat of hair; a thin, mellow skin; and fineness of bone, are features that show refinement, or quality。 Coarseness of head; large ears for the size of the body; wiry, heavy hair; and coarseness of bone, indicate lack of endurance and weakness of constitution. A large, coarse bone is more porous and less strong in proportion than one that is finer and smaller. Fineness and softness of skin is an indication of good secretions and healthy internal organs. If ample quality occurs, we get the most durability and stamina, or power of endurance.

The disposition of the horse is usually seen in the prominence and character of the eye and the carriage of the cars. If the eye is prominent and the whites clear, and the expres- 
sion pleasant, the disposition will probably be good. A small, sunken eye indicates a bad temper. Ears that are carried erect or that point forward rather than backward show a good temper. If the ears lop about, there is evidence of laziness.

The height of the horse is usually expressed in "hands," a hand being equal to 4 inches. The height is measured in a vertical line from the ground to the top of the withers. A horse 16 hands high would stand 64 inches from the ground.

The weight of the horse, in a degree, indicates to what class he belongs. A mature horse weighing 2000 pounds would naturally be a heavy draft animal. If weighing 1000 pounds, it might be one of several types. In Europe, the height of the horse rather than his weight is looked upon as of the most importance.

The age of the horse is estimated by an examination of

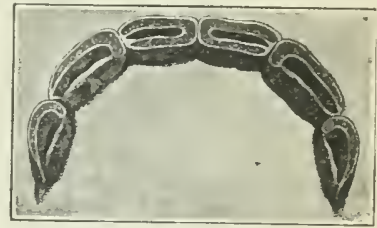

Fig. 73. Age of the horse as shown by the teeth. $1 \frac{1}{2}$ years old. Figs. 73-50 reproduced from "Beurtheilungslehre des Pferdes," 1859 . the teeth. It requires some experience to be quick in recognizing the age, which may be determined with fair accuracy up to eight years, after

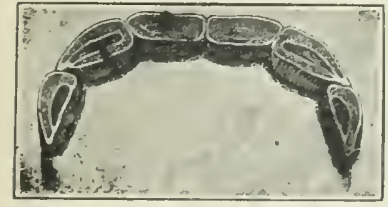

Fig. 74. 21/2 years of age. which it becomes a matter of guess work. The following items are the important guides to age.

The colt's teeth. Seven or eight days after birth, two incisor tecth appear at the front and middle of both upper and lower jaws. In the course of five or six weeks, two more teeth appear in each jaw, one tooth coming in on either side of the two already present. 


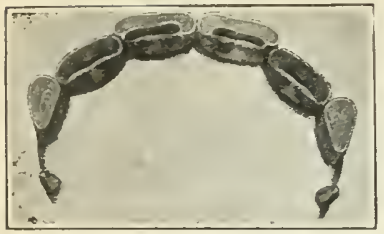

Fig. 75. $3 \frac{1}{2}$ years old.

Some time between the sixth and ninth month, two more appear, one by the side of each outer tooth. These six pairs are called nippers. They are the milk teeth, and are only temporary. They are not all equally level with one another at first, but in the course of 12 months or so they become uniform on the surface. The outside of the tooth is a very hard, white enamel. This covers a hard, ivory-like bone, while at the center is a soft, bony substance which more easily wears away, but is constantly renewed. The ends of the teeth have a ridged eutting surface, forming at the centers small depressions, or "cups," marks by which the age is determined. The cups in the central pair of nippers at first are dark of center; in the second

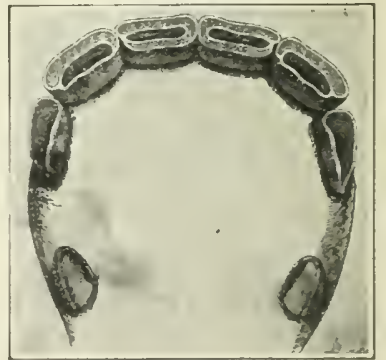

Fig. 76. 4 years old. year they begin to wear light in color, and these cups become smaller than those of the other four. Similar

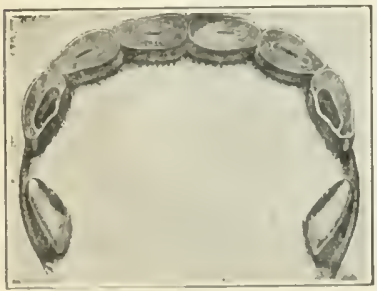

lig. 77. 5 years old. changes follow in orler in the other pairs.

At three years of age, permanent incisors or nippers begin to appear. These teeth are larger than the first ones, which were small but suited to the mouth of the colt. The first or 
central pair of temporary teeth is pushed out or aside by a pair of larger, permanent ones.

At four years, the second pair of nippers in each jaw of the colt gives way to two larger, permanent teeth.

At five years, the last pair of colt's teeth in each jaw is re-

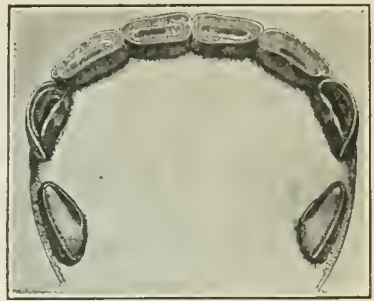

Fig. 78. 6 years old. placed by permanent teeth. At this age, what are called tusks appear in the mouth of the male. These teeth have roundish points, and there are two in each jaw, one on a

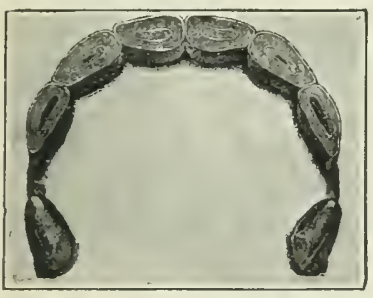

Fig. 79. 7 years old. side, a short distance back of the front teeth. After the fifth year the age of the horse is determined by the appearance of the wearing surface of the teeth, each tooth having its age surface.

At six years, the cups of the two central teeth are worn off. At seven, the second pair shows the worn surface; and At eight, all the teeth have been worn about level, and the mouth mark loses its value.

The six permanent teeth in each jaw at first meet each other in much the same position, the ends of the tecth coming full head on. As age increases, the teeth gradually take a more inclined or slanting-out position in each jaw, so that they come together at a sharper angle. The

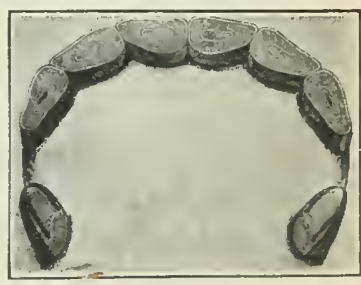

Fig. s0. s years old. 
older teeth are also more worn off at the surface, and are longer than the younger teeth. In horses from 12 to 16 years of age, the ends of the teeth become somewhat threesided. The following unique poem may assist some in keeping elear in mind the ehanges which take place in the mouth, by which the age of the horse may be decided.

The Age of the Horse in Verse.*

Two middle nippers you behold

Before the colt is two weeks old;

Before eight weeks two more will come;

Eight months, the "corners" cut the gum.

The outside grooves will disappear

From middle two in just one year;

In two years, from the second pair;

In three, the "corners," too, are bare.

At two, the middle nippers drop;

At three, the second pair ean't stop;

When four years old the third pair goes;

At five, a full new set he shows.

The deep black spots will pass from view,

At six years, from the middle two;

The second pair at seven years;

At eight, the spots each "corner" elears.

From middle nippers, upper jaw,

At nine the black spots will withdraw;

The second pair at ten are white;

Eleven finds the "corners" light. 
As time goes on the horsemen know

The oval teeth three-sided grow;

They longer get, project before

Till twenty, when we know no more.

The soundness of the horse is regarded as very important. Many unsound horses are bought by men who think them sound. Then when these men attempt to sell, these horses often show a great loss on the purchase price. Therefore, if one is to be a capable judge, he must be able to distinguish cases of unsoundness. This is not always easily done. Some forms are not clearly apparent until well established. If the respiration is not good, this is brought out in some form of work, such as trotting, hauling a load, etc. In the sale markets, horses are hitched to wagons with brakes, so that they may be required to make quite an exertion in moving along.

Heaves is an unsoundness or trouble of the lungs which is brought on through dusty feed, bad ventilation, or indigestion. Broken wind or asthma is apparently much the same thing. When the horse expels wind from the chest, he lacks the muscular contraction of the lungs that attains with the sound animal, and makes a wheezing noise, which is sometimes very loud.

Roaring is another discase in which the horse makes a loud noise during breathing. The larynx is affectcd, but not the lungs. This is a paralysis of the nerves and muscles of the parts, which results in the noise in breathing. Roaring is manifested during exertion, yet a horse may be a roarer and be driven some distance without making much if any noise. The disease is one of progression, and gradually becomes worse. Roaring has always beerr considered incurable until recently. Dr. Williams of Cornell University 


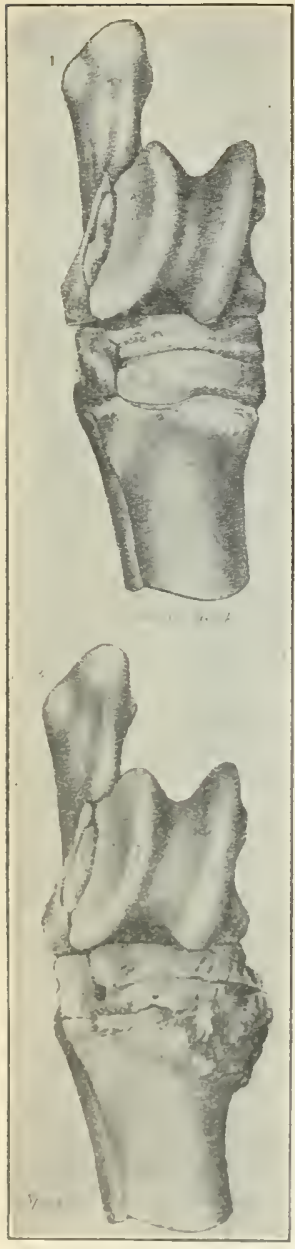

Fig. 81. The upper picture shows a sound hork joint; the lower, one with at spavin. Reproduced from "Diserases of the 11orse," U.S. Dept, of Agriculture. discovered a method of operating by which the roaring may be cured, and what is known as the Williams' operation is now performed with success in Ameriea and Europe.

Spavin, also frequently called bone spavin, is usually found at the lower part of the hock joint, on the inside of the leg. It is caused by a strain or injury, and consists of an accumulation of bony matter at the joint. This is shown in a more or less thickening of the part, as compared with the sound hock. The occurrence of the spavin is most easily seen by standing directly back of the horse and viewing the parts from the rear. The spavin causes lameness and a stiff gait, and is regarded as a serious unsoundness. It greatly damages the sale value and is more common on light than on heary horses.

Curb is also an unsoundness of the hock. When sound, the back of the hock, slightly below the point, has rather a perpendicular or straight edge. If a curb exists, there is a bulging or outward curve a short distance below the point, that may be seen by standing opposite the hind leg. Hocks that do not have curbs, yet that tend to round out at this part of the leg, are said to have a curby' conformation. Curbs 
are due to strains, and while an umsoundness, are not of the more serious kind.

Bog spavin is a small, lound form of tumor, located in the front and inner side of the hock. If pressed, it may appear on the outside and rear part of the hock.

Thoroughpin is a swelling in the rear part of the hock at its thimnest point. Here, under ordinary conditions, the hock is curved to form graceful outlines with a pronounced depression. If thoroughpin occurs, a swelling will be noticeable on each side of the hock at this point. Bog spavins, thoroughpins, or a puffed condition about the hocks, are seen most frequently on large, heavy horses that have what are called thick, meaty hocks. Horse dealers are inclined to refer to these as little puffs that will disappear with work, and so minimize their importance. It is true that heavy horses that stand in the stable, frequently swell in the lower

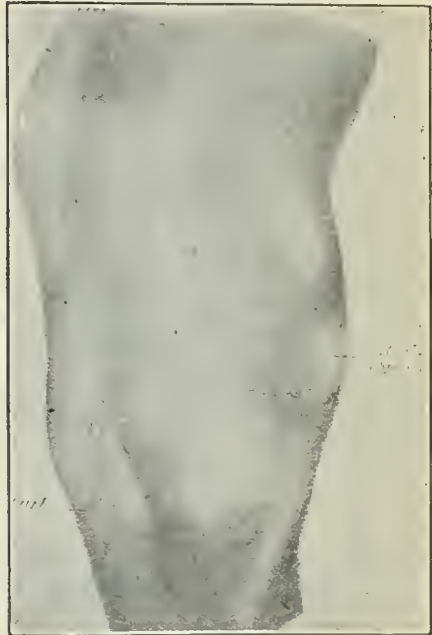

Fig. 82. The hock from one side, showing bog spavin in front and curb behind. Reproduced from "The Diseases of the Horse," U. S. Dept. of Agriculture. half of the legs, a condition that exercise removes, but bogs and thoroughpins are distinct unsoundnesses that exercise will not drive away, and that injure the sale value of the horse.

Sidebone is found in the rear part of the front foot on the coffin bone at the crown or top of the hoof. It is due to the hardening of eartilages, whereby they take on a bony 
character, which causes lameness. In well-defined cases, the sidebones appear as hard projections just beneath the skin, and can be plainly seen or felt. In their early stages, sidebones are not so easily discovered, and one may buy a horse that appears sound, yet in a short time the trouble will

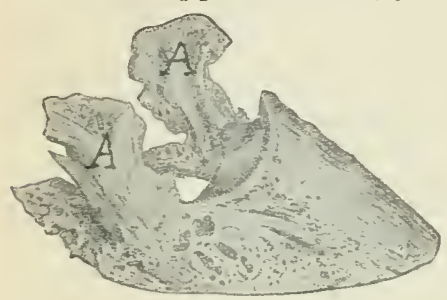

Fig. 83. Sidebone shown at $A$ on bone in the foot of a horse. Reproduced from "Diseases of the Horse," U.S. Dept. of Agriculture. become noticeable. Sidebones are most common on draft horses, and on those used on hard roads or pavements. This unsoundness is severely discriminated against and shrewd men will not buy horses that have sidebones.

Ring bone is a bony deposit which in the form of a ring encircles the upper part of the foot or the pastern. On old horses this bony enlargement sometimes becomes very conspicuous. It may be due to hard labor, strains, bruises, etc., and if well developed, causes serious lameness.

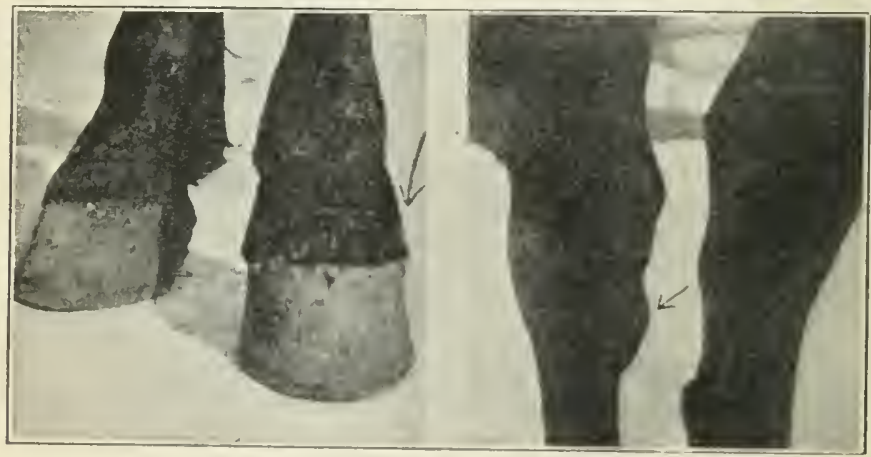

Fig. St. Ring bone above foot, as indieated, and spavin at lower part of hock near point of arrow. Reproduced from Circular 29, Jurdue Experiment
Station. 
Splint is a bony projection or roughness usually found on the inside of the splint bone, which lies close in with the cannon bone of the front leg, and is commonly regarded as the cannon. This is not considered a distinct unsoundness, although very common and referred to quite frequently. Splints sometimes appear on young horses and then disappear with the mature development of the animals. Splints may be easily seen while standing in front and looking at the inside of the legs.

Quarter-crack is a splitting or cracking of the bony part of the hoof, usually of the front foot. This crack may extend the entire length of the hoof, and be so bad as to require fastening the parts with metal clamps or nails to keep the cracks from extending or widening. Horses with brittle or soft hoofs are most affected with this trouble. Quarter-crack may develop so far as to break through the lower part of the foot and

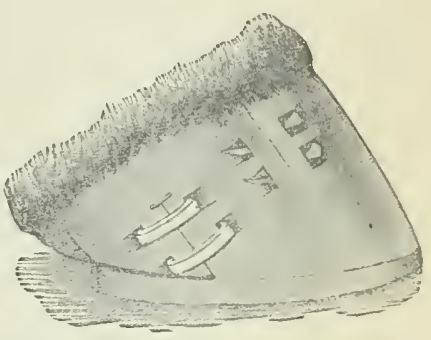

Fig. 85. Quarter crack. Reproduced from "Diseases of the Horse," U.S. Dept. of Agriculture. cause serious injury and lameness.

Toe-crack is similar to quarter-crack, but is usually on the hind foot, in the front part, and often extends the length of the hoof.

Founder, or laminitis, as the veterinarian calls it, is an unsoundness of the feet. It is due to an inflammation of the delicate tissues within the hoof, and is usually found in the front feet. It is caused by a variety of conditions, such as overwork, overfeeding, exposure, etc. If well established it is incurable and causes the horse much suffering. The common symptom of this trouble is lameness, which is 
often very severe. When standing, the horse as a rule reaches the feet somewhat forward, resting the weight upon the heel. The hind feet, which carry most of the weight, are placed well under the body. The more perfect the foot, the less liable the horse is to suffer from founder. A very flat foot, or one with very high hoof walls, or a foot that is quite contracted, is liable to be affected with this trouble.

Navicular disease is an inflammation that also occurs in the foot, affecting the sesamoid sheath and the navicular bone. This occurs most commonly with race horses, and those having great knee action. Usually but one forefoot suffers from the disease, which is caused by concussion and shock to the affected parts. The early stages of the disease are not commonly noticed. Attention is first directed to the "pointing" of the foot, which is extended forward, the weight resting on the toe, and as the trouble develops, lameness is noticed, which increases with use of the horse. But few cases of navicular discase recover.

Cocked ankle, or knuckling, is a partial dislocation of the pastern or fetlock joint, in which case the pastern becomes more perpendicular than usual, throwing the joint forward out of natural position. This is not always an unsoundness, but is a defect, in that it causes stumbling and clumsy action.

There are some other forms of unsoundness that are not especially common. There are also some diseases that become chronic as external features, such as fistula and poll evil. These wo are manifested by swellings and finally rumning sores at the withers or poll, as the case may be. The unsoundnesses described, however, are those of common occurrence, and are most likely to attract attention. 


\section{IN DISCUSSING THE POINTS OF THE HORSE}

1. Where is the muzzle, and why should it be of good size?

2. What kind of shoulder is most desirable?

3. Locate and describe the cannon bone.

4. Explain why the pastern should be sloping.

5. Describe the frog and its use.

6. Discuss good and bad croup conformation.

7. Locate the hock, and discuss its form.

8. Explain the movement of the leg.

9. Discuss differenees of action of coach horse and roadster.

10. What is meant by a "hand?"

11. Explain the meaning of milk teeth, and their occurrence.

12. What are the eups??

\section{A FEW OBSERVATIONS WORTH MAKING}

13. Compare "points" on the home farm horses.

14. Compare horses on the town streets.

15. Examine feet when at rest.

16. Observe movements of the feet of horses driven on the road.

17. Inquire of blacksmiths if they shoe to affeet the action.

18. Examine the teeth of colts and older horses, and obtain practice in judging age. 


\section{CHAPTER IX \\ JUDGING THE HORSE}

The judging of carriage or light harness horses is done on the basis that they are valued for speed and the drawing of carriages and lighter vehicles. As stated in Chapter VI, this type of horse is comparatively light of weight, is long and narrow rather than short and thick, yet has a muscular appearance. In this class we find somewhat striking differences in type, as is seen by comparing a high-class Hackney

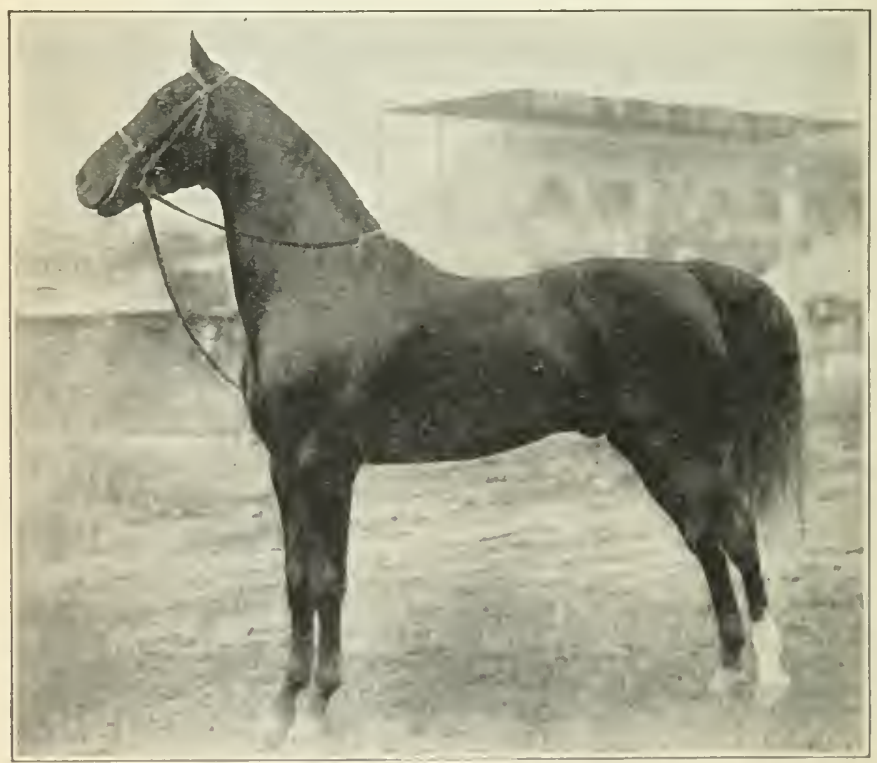

Fig. S6, A saddle horse type. IRer Chicf A. Owned by Thomas Bass, of Missouri. Photograph by couriesy The Farmer. 
with a light type of trotter. The American Saddle horse is also in this class, for he has many of the characteristics of form of the carriage horse. In order to cause no confusion, a score card for carriage horses is given on page 160. There will be no difficulty in most communities in finding horses of this type which may be used for score-card practice. This score card is the style commonly in use, containing a blank column in which the student as judge may write his own score, with another column in which the score of the instructor may be written for comparison.

The height of the carriage horse may vary, but 16 hands is a good standard, with 1100 to 1200 pounds for weight.

The general appearance of the carriage horse can best be studied by standing off some distance, such as ten feet or more, and making an inspection which will take in the entire form, the quality, and disposition. One should not be too close to the animal for this first examination. At a distance one also gets an impression of character, as shown by the head and neck, that cannot be so easily noticed otherwise.

The head and neck of the carriage horse should show plenty of intelligence, style, and alertness. Refinement of head and ears is important, and the neck should have length and not be coarse. A straight line along the top of the neck, or a slight crest with the males, is looked upon with favor. A thin, ewe neck, one that is depressed on top, is undesirable, and is unpopular among buyers.

The fore quarters of the carriage horse should show a smooth, well laid-in, yet muscular shoulder. While great strength is not essential, a wide, strong, muscular arm, and long, wide-topped forearm are favored:- What is called a clean, smooth, flat bone is a very important feature. Clean- 


\section{Carriage Horse score Card}

Srale of Points.

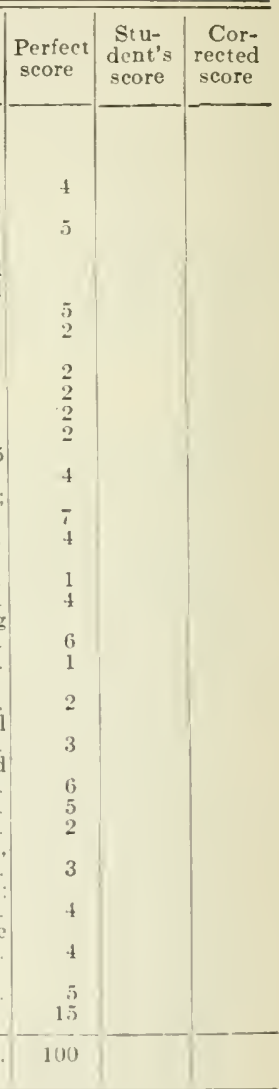

GENERAL APPEARANCE:

Note height a ND Weight

Fory, long, deep chested, muscular

QUALITY, neat, lean head; fine hair; mellow skin; clean bone and joints; disposition active and pleasant

HEAD AND NECK:

HEAD, well defined; forehead broad; eves bright and prominent; muzzle fine, with large nostrils and thin lips; ears of medium size, and alert

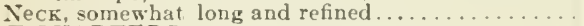
FORE QLARTERS:

Shoulders, long, smooth and oblique...........

Arys, short and muscular; forearm long.

KNEEs, wide in front, straight, and deep through

CAxxoxs, short, flat, strong.

Fetlocks, wide, and pasterns strong, oblique 43

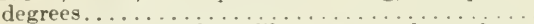

FEet, medium size, slope like pastern; horn dense: frog large; heel wide...................... BODY:

LEGS, properly placed, and not too close together. .

W ITHERs, muscular and well set back

Chest, deep, girth large.

BACE, strong, short, muscular, well carried; ribs long and arched; loin short and broad

UNDERLINE, long, well down in the flank......... HIND QUARTERS:

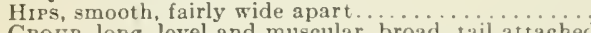

CROUP, long, level and muscular, broad, tail attached

Thighs, long, muscular, quarters strongly muscled

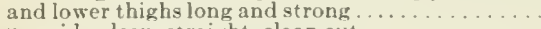

Hocks, wide, deep, straight, clean cut. . . . . . . . . .

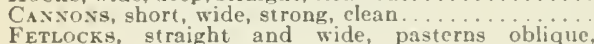

FEet, medium size, slope like pasterns; horn dense frog large; heel wide......

LEGs, properly placed for rapid speed, not too elose ACTION:

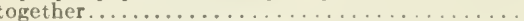

WALK, elastic, quick, balanerd

TROT, rapid, straight, with long stride...

Total score

100

SaME of aximal................ Breed.

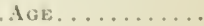

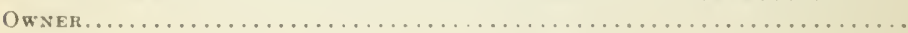

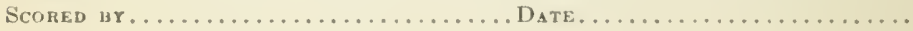


ness and lightness of limb are much valued by buyers of this class of horses. Strength and quality go with legs of this kind.

The body of the carriage horse will appear deep but not thick, and will at its best have a sleek, well-rounded appearance. By standing off at one side, the judge will get a better view of proportions, and the fullness of chest, and depth of both front and hind flanks will be easily seen. A view from squarely in front will show the prominence of breast, and the thickness and depth of body below the placing of neck, which should be smoothly blended into the body. There is quite a good deal of variation in the withers of driving horses. They should not be very sharp, but fairly well muscled and not appear too prominent. Notice if the back is strong and well carried, with the loins broad and not much depressed below the level of the croup. The well-turned carriage horse will show a fullness of body. from various points of view. The greater speed he is capable of making, the more muscular and angular he will appear. This is illustrated by comparing a carriage horse and a working trotter, each being about the same size, but used for a different purpose.

The hind quarters of the carriage horse show power. As one stands at one side, the length of croup and its position are easilyseen. A long, strong, high rather than low croup is desired, with the tail having a free, easy, and somewhat high carriage. The length from the hips to the point of the hocks should be considerable.

The distance from the hind flank diagonally across to the setting on of the tail also should be comparatively long. As one stands behind, he should be able to observe some thickness below the tail, where the hind legs merge together into the thick, muscular quarters. A driving horse is not likely 
to be too thick in the quarters. As one riews the horse from behind, the legs should reach back, with the hocks separated about four inches, and the lower thighs showing a strong muscular development from both rear and side views. At the stifle joint, where the upper and lower thigh connect, fullness rather than depression should oceur. The hocks should be inspected from the front, at one side, and from behind. It is important that they be elean, well-turned, and straight. Careful examination should be made of this part, for the hocks require much study. The occurrence of bone and bog spavins here, and often a puffy condition that is objectionable, may escape notice.

The legs of the horse must be inspected from in front and from one side. A true carriage, in any event, is important. Standing in front enables one to see the straightness of limb, and in a way that shows the relation of each leg to its mate. From this view we judge whether the ankles will interfere when the horse is in motion, or whether or not a true gait is possible. From one side we note the position of the legs, to determine balance of action. If front and hind legs are tucked too much beneath the bolly, they are liable to come in contact with each other when in rapid action. If there is too much stretch and separation between the limbs in front and behind, then the action will lack power. In a natural pose at rest, the front legs will incline very slightly under the body, with the hind legs correspondingly extended behind. The picture on page 145 , although of a draft horse, illustrates this position.

A foot inspection of the horse begins with the foot at rest and in a natural position. Thus one is able to note the form, the placing on the ground, shape of hecl, and the upper condition of foot, with its relation to the pastern and to the fetlock joint. The foot, however, should be examined on its 
under side, and so must be raised for inspection. The fore foot is usually started easily by running the hand nearest the horse down the shoulder and arm to the back of the cannon, and pressing on the tendons with the ends of the fingers, raising the leg at the same time, using the other hand to catch hold of the hoof as it is raised by the horse. With one hand the hoof may be easily held, while with the

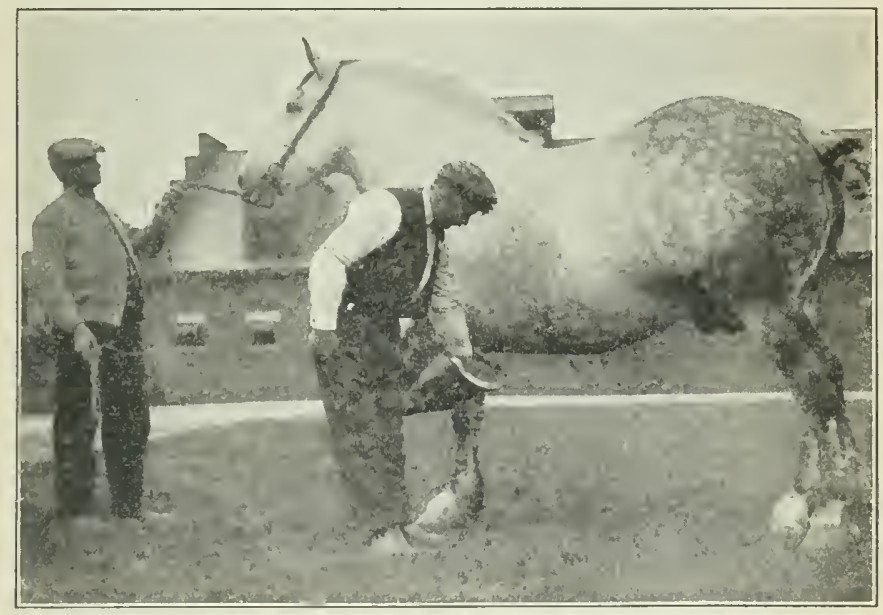

Fig. 87. Examining the front foot of horse, showing method of holding. Photograph by the author.

other, any accumulated material under the foot may be removed by the use of a small pick of some sort. One may then easily examine the lower part of the foot. The hind foot is examined somewhat differently. If wishing to inspect the left hind foot, the left hand is placed on the croup and quietly slipped down over the thigh to the muscle just above the hock, where a firm pressure with the fingeis is given. At the same time the right hand is placed upon the pastern, and the 
foot and leg firmly but quietly raised upward and backward, reaching away from the body. This brings the hoof in front of the examiner, with its lower surface facing to the rear, and at about knee height. No great effort should be marle in raising the feet, for the horse will easily support himself on his three other limbs. Young horses require more

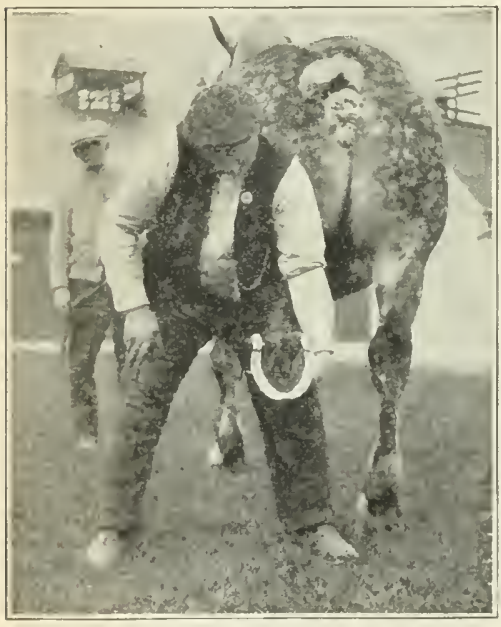

Fig. Se. Shrowing correct pasition for holding and examining the hind foot. Photograph by the author. patience than old ones in foot examination, but after a few shoeings, with horses of good disposition no trouble may be expected. It is wise to move with care about the hind legs, especially directly in the rear, to avoid the chance of being kicked.

The study of action is most important with the driving horse. How high a valuation should be given to the gait will depend upon the use of the horse, and the kind of shoes he has on his fect. All carriage horses, and race horses in particular, are so shod as to regulate their action, if used by men who know the relation of form and weight of shoe to foot and leg movement. A fancy driver should show a smappy, stylish action, with the knees and hocks carried rather high and strong. A roadster will show: a longer, more powerful, yet plainer gait, with not so high or short movement. II hen action is being inspected, the horse should first be led at a 
walk in a direct line toward and then away from the judge, who should carefully note the trueness of morement of the limbs and the way the feet are carried. Next, the horse should pass by at a walk, so that the inspection may be made from one sicle, to observe the freedom of

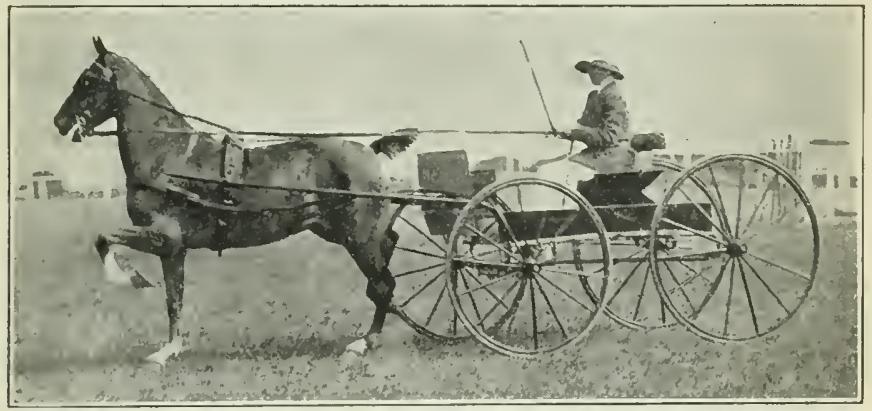

Fig. 89. Queen Pandora, an example of knee action. Owned by Mrs. C. C. Fillers. Photograph by courtesy of Bit and Spur.

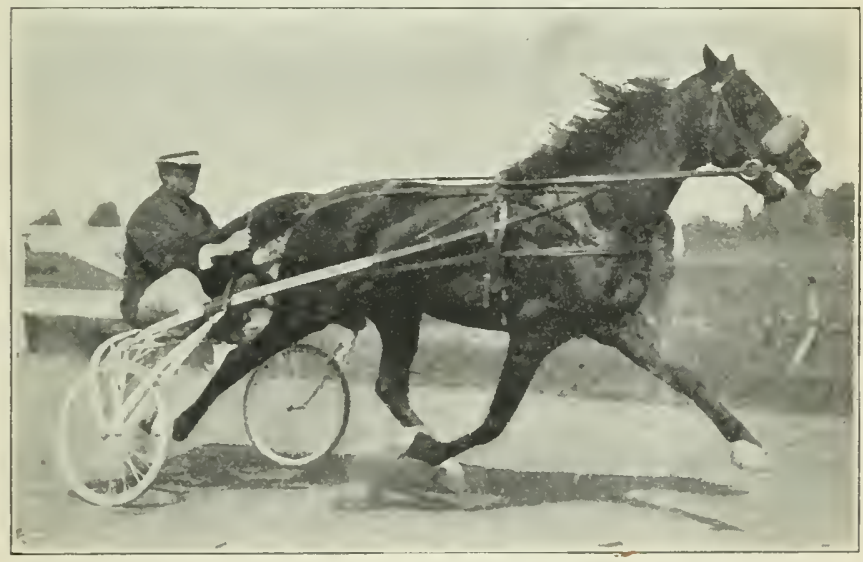

Fig. 90. An example of a long, powerful stride in ease of a light harness horse. Notice but one foot is touching the ground. 


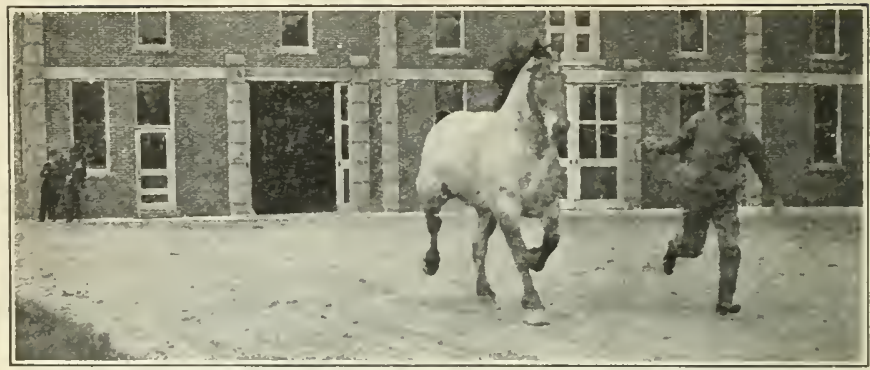

Fig. 91. Study the action as the horse comes toward you standing directly in front.

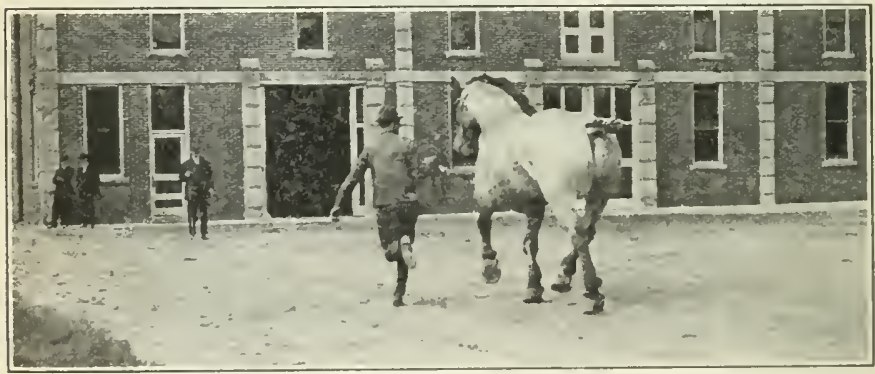

Fig. 92. Study the action as the horse leaves you, standing directly behind.

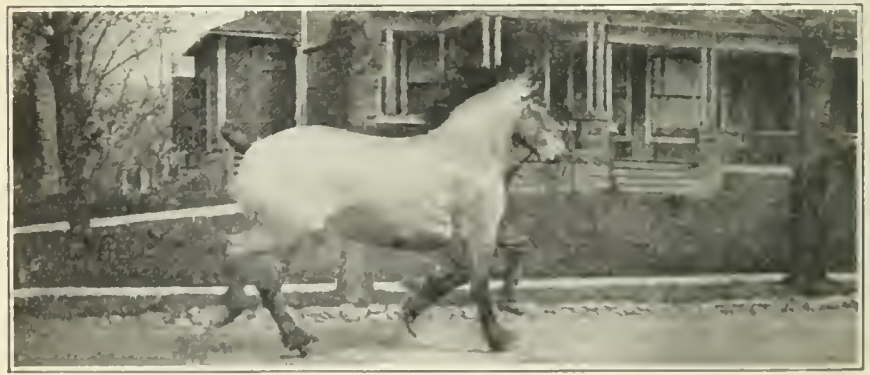

Fig. 93. As the horse goes by at one gide, note the knee and hork action. Photographs by courtesy of Purdue University School of Agriculture. 
movement, and flexing of knees and hocks. The next step will be to require the horse to go and come at a gait faster than a walk, the judge assuming the same positions as before while the walking gait was being studied. Seeing the horse at the walk and trot, or other rapid movement, will enable him to draw a conclusion as to the merits of the gait. As 20 points are eredited to the action of the carriage horse on the score card, it may be seen that this feature is highly valued. Persons differ in their appreciation of action, and some are naturally much better judges than others. However, if one will study the action from the three points of view mentioned, one will soon begin to see how horses differ in this regard.

The judging of the draft horse is conducted in the same manner, in many respects, as with the carriage horse. The general methods of study are the same. The purposes of the drafter, however, are different, and one must have in mind at all times draft size and conformation. The following score card on page 168 is arranged for a study of the horse of draft type.

In the study of draft conformation, emphasis must be placed on two features, weight and conformation. The size must be large and massive, and the nearer the weight to 1800 or 2000 pounds, the truer will be the draft form. An examination from any point of view will show this horse to be deep and thick, both at the ends and in the middle, with a compact, powerful body set on rather short legs. There are some details the student should keep in mind in this examination.

The head and neck will show considerable size, without the delieate chiseling of head of the lighter horse. The neck will be heavily muscled and moderately short. 


\section{Draft Horse Score Card}

\begin{tabular}{|c|c|c|c|}
\hline Scale of points & $\begin{array}{l}\text { Perfect } \\
\text { score }\end{array}$ & $\begin{array}{l}\text { Stu- } \\
\text { dent's } \\
\text { score }\end{array}$ & $\begin{array}{l}\text { Cor- } \\
\text { rected } \\
\text { score }\end{array}$ \\
\hline 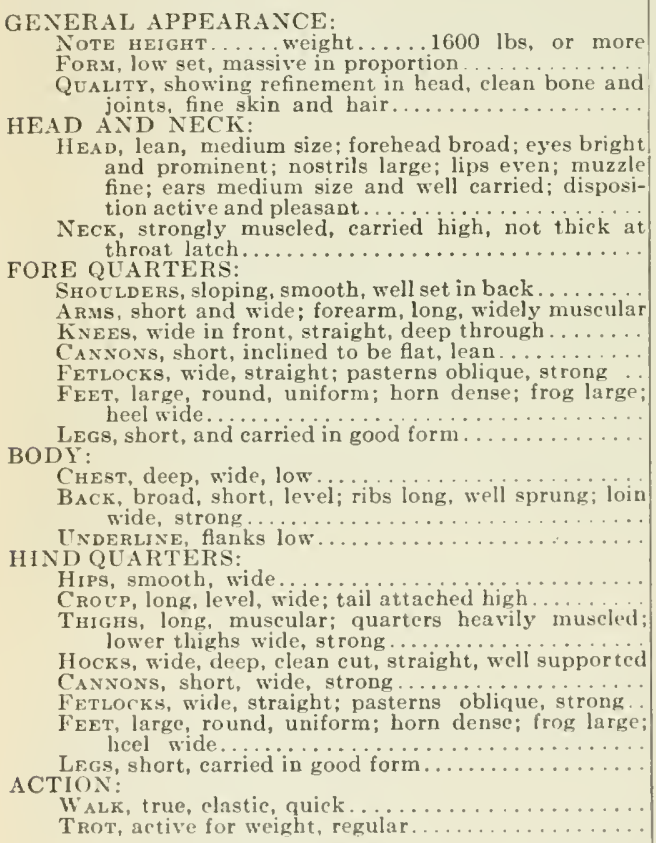 & $\begin{array}{l}3 \\
2 \\
2 \\
3 \\
2 \\
2 \\
3 \\
8 \\
4 \\
4 \\
2 \\
6 \\
1 \\
2 \\
4 \\
6 \\
8 \\
2 \\
3 \\
7 \\
5 \\
6 \\
4\end{array}$ & & \\
\hline Total score..$\ldots \ldots \ldots \ldots \ldots \ldots \ldots$ & 100 & & \\
\hline
\end{tabular}

NAME DF AXIMAI.

BREED.........AGE........

(TWXER.

SCORED BY

DATF 
The shoulders of the draft horse are usually less sloping than those of the lighter type, and are not laid back in quite as smoothly. The slower, more moderate draft action is associated with this upright form of shoulder.

The cannons of the drafter incline to be somewhat thiek and round, especially in front. There is no danger of their being too flat or too short, and emphasis should be placed on this.

The pasterns of the draft horse often appear short and rather erect. To give the easiest movement, they should have fair length, and a slope of about 45 degrees. Some draft breeds have a longer pastern than do others, as for example the Clydesdale, which is noted for length and springy character in this respect. A short, stubby pastern is very undesirable, and goes with a hard gait that punishes the feet and causes trouble.

The feet of the draft horse must show considerable size.

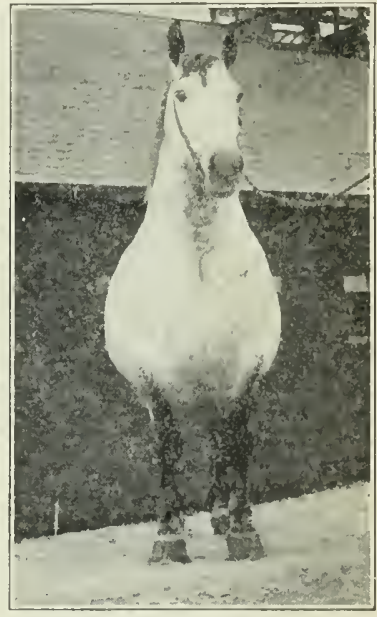

Fig. 94. A draft horse in excellent position from the front. Photograph by the author. The forefeet in partieular should not look too small in proportion to the rest of the body, and it is well to emphasize the quality of the hoof. The feet of horses of this type, especially those in front, are subject to severe strains, due to the great weight placed on them and the hard work on the road. This part should be most earefully examined. The old English saying, "No feet, no horse," has no greater application than with the drafter. 
The hind quarters of the draft horse especially signify power. Therefore great length and breadth of the croup provide for thick powerful muscles. As one looks at this part, he should be impressed with the power there available. A common feature of the draft horse at this point is steepness of croup. This is easily seen whether one stands at one side or looks from behind. We do not have much information

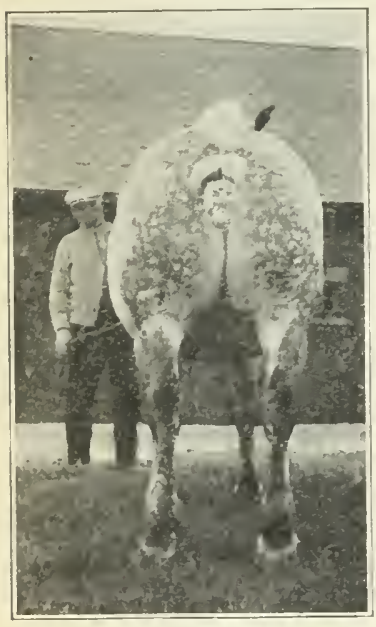

Fig. 95. A draft horse from the rear, with the legs too wide apart. Photograph by the author.

on the difference in power between horses with steep croups and those haring them more level, but it is generally agreed that the most beautiful conformation goes with the more level condition. The greater the length and the more heavily the muscling from the hips to the hock, the more powerful will be the croup conformation.

The legs of the drafter should not appear too wide apart at either hock or knee. Too much spread is a greater indication of weakness than is closeness. The limbs should come down in a well-placed position, to stand under somewhat at each corner of the body, as it were. In viewing the horse from in front, one is inclined to look for too great width, such as goes with a stiff or clumsy gait.

The action of the draft horse is studied in the same way as with the driver. More value, however, is in this case given to the walk than to a faster gait. A heary draft horse is rarely required to move faster than a walk. However, he should have a quick walk, and be able to move four miles an 
hour in a free, easy manner. Many heavy horses tend to carry the feet to one side somewhat when in motion. This is in a measure due to the straight, open-topped shoulder. When watehing the horse in aetion, look for a strong, only moderately high knee and hock movement, but do not look for much speed. The heavy horse, however, inclines to drag his feet, and this should be watehed for. As one stands behind, he should easily see the glisten of the shoe as each foot is raised. There are just as wide extremes in action among draft horses as among carriage horses, but not so much should be expected from the former as the latter.

Opportunities to study horses are frequent, either in the country or in town. If one is observant of the horses that are constantly passing, much information of value will reward the effort.

Comparisons may be repeatedly made, for

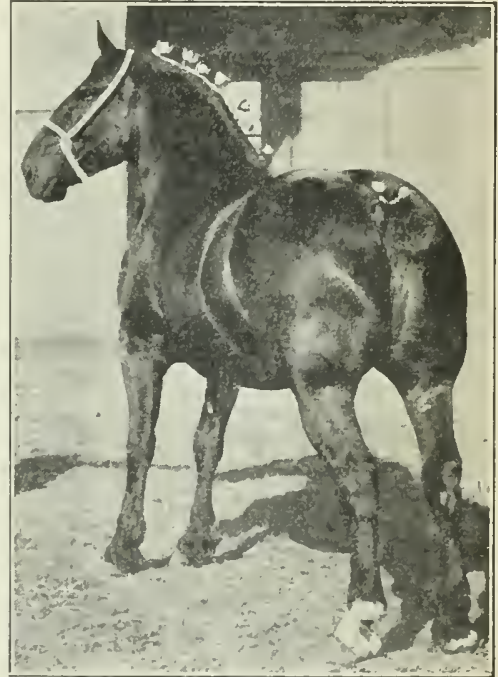

Fig. 96. Powerful draft horse conformation from behind. The camera being nearer the hind legs than the front ones, the former apnear much too long and out of proportion. Photograph by courtesy The Farmer. two-horse teams always provide such an opportunity, while in many public places two or more horses are frequently standing side by side, interesting subjects for comparison. 


\section{AS A JUDGE OF HORSES, WHAT} card?

1. Features are given the most credit in the carriage horse score

2. Kind of head and neck should the carriage horse have?

3 . Is the best method of inspecting the legs?

4. Manner of front foot examination is desirable?

5. Kind of action will be shown by a fancy driver? cards?

6. Inportant differences exist in carriage and draft-horse score

7. Size is desirable in the draft horse?

8. Slope should the pastern of the draft horse have, and why?

9. Description can you give of the croup of the draft horse?

10. Importance should be given draft horse action?

\section{FOR OUTSIDE OBSERVATION AND STUDY}

11. Make or get some score cards, and score a few of the horses at home or of the neighbors.

12. Get up a small horse show among the neighbors and have a judging contest. Interest the local horsemen.

13. Learn, if possible, who owns the best type of stallion in the community. Why is he best?

14. Report on the horse judging at some fair, if you have opportunity. 


\section{CHAPTER X \\ THE JUDGING OF CATTLE}

As has already been indicated in the discussion in Chapter VI, our domestic eattle may be sorted into different types and classes, according to their uses. However, it is not important that we go into detailed study in this large field. Special attention will be given to two types, such as are

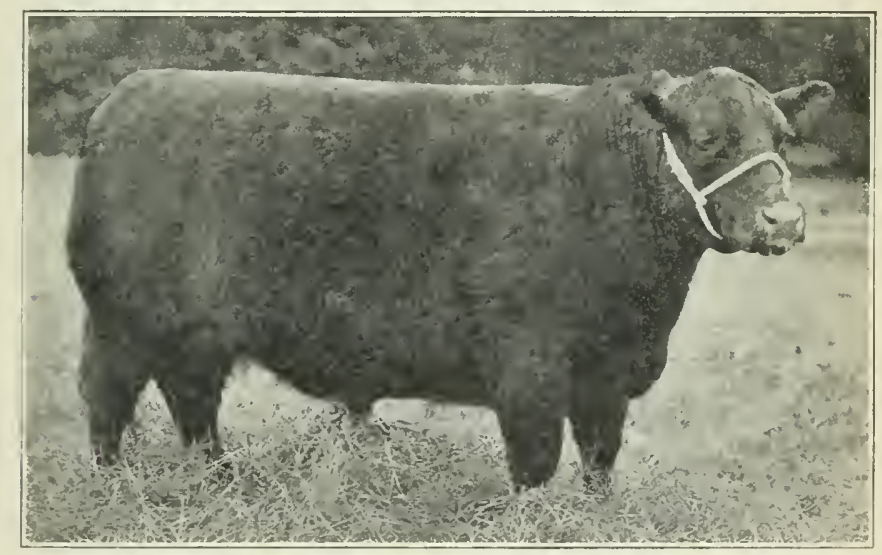

Fig. 9 $\vec{\imath}$. Victor, grand champion steer at the 1911 International Live Stock Exposition. Shown by the lowa State College. Photograph by courtesy The Farmer.

most common over the country, namely, beef cattle and dairy cattle. If one has a clear understanding of these, he will have but little difficulty in becoming acquainted with the variations to be found outside of these two wellestablished forms. 


\section{JUDGING BEEF CATTLE}

The form of the beef animal, as indicated by the score card which follows, should show breadth, depth, and compactness. Then if this includes an excellent degree of fatness over the body, known as condition, the butcher will obtain from such a carcass the greatest percentage of the most valuable cuts. Some writers on live stock have compared the body of fat cattle to a rectangle, when vicwed from one side. The body of the animal, excepting the head, neck, and legs, would very well fill a rectangular form. Viewed

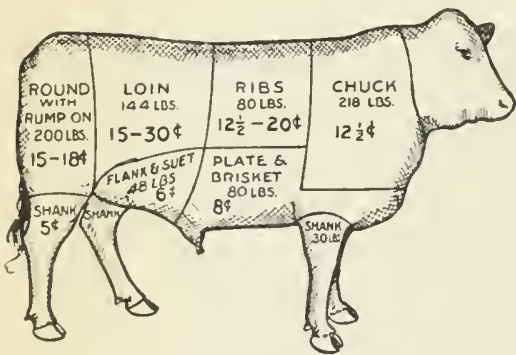

Fig. 98. Diagram showing the way the carcass of fat cattle cuts into wholesale pieces, and comparative values. By courtcsy The Farmer. from either the front or the rear, the body should fill a square. Long ago English writers made use of this illustration of correct beef cattle form, and judges of today very generally approve of the same description. If we examine a body that is described as "blocky," it will be noticed that those parts containing the highest priced meats are well developed. The part from the hips forward to the last rib comprises the loin. The highest priced meat is found here, and makes up about 17 per cent of the carcass. The section of the back and ribs from the loin up to the sixth rib, known as the rib or prime-of-rib cut, makes up about 9 per cent of the carcass, and is worth two or three cents less a pound than the loin. The rib part of the back at the shoulders makes up about 26 per eent of the carcass, and is still cheaper than the prime- 
of-ribs. If we view the steer from behind, the rump and quarters fill out into one of the heaviest and meatiest parts, comprising 23 per cent of the carcass, and ranking third in value of the different cuts. Thus we see that the more completely the frame of the animal is developed in these parts, and covered with a thick, smooth, uniform layer of good meat, the greater its value will be for beef. The head,

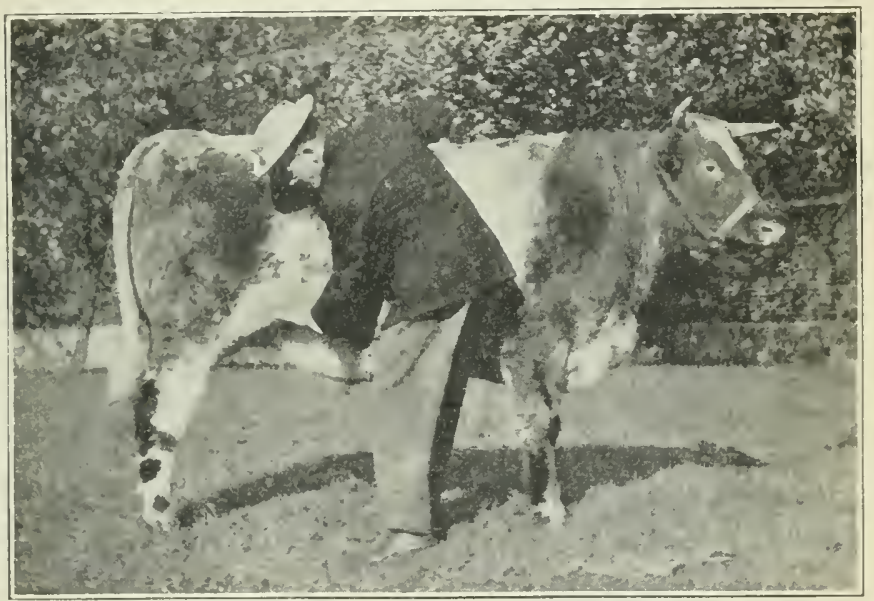

Fig. 99. Feeling for thickness of flank of beef animal. Photograph by the author.

neck, belly part, and legs are rated as cheap meat, and therefore these parts need not be heavily developed. The animal with big paunch and long leg is cliscriminated against by buyers, who realize that in killing, considerable waste is sure to result. High-class fat cattle will kill out as much as 70 per cent, or even more, carcass to offal, while a common or inferior animal of leggy conformation will dress around 50 
per cent. Thus the butcher usually prefers to buy the better elass of animals, which dress out 60 per cent or more.

The condition of a beef animal refers to the covering of flesh or degree of fatness. Thin animals are spoken of as in thin condition, while fat ones are in fat condition. The condition is determined mainly by the eye of the judge. The well-fattened animal shows plumpness of body. His more exposed portions, like the hips and shoulder points, are

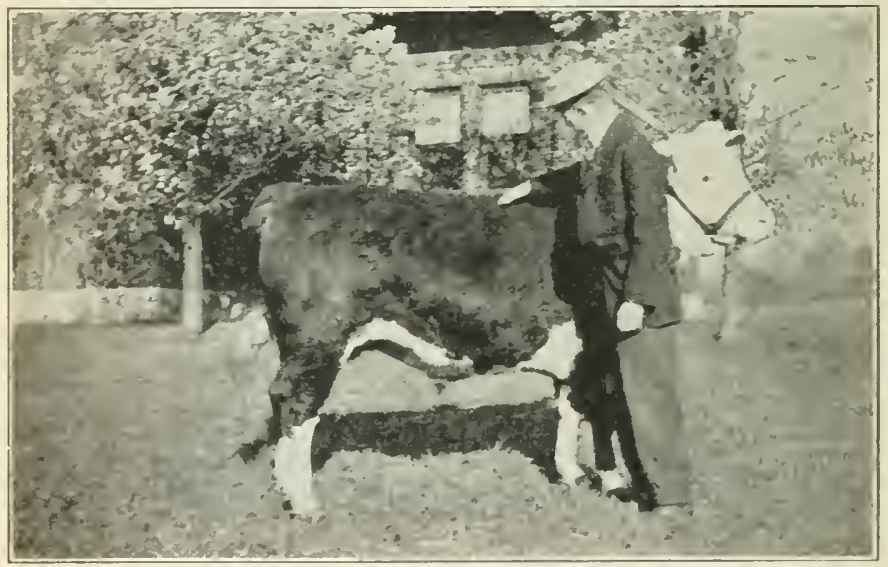

Fig. 100. Feeling along the back of a steer to study depth of eovering of flesh. Photograph by the author.

covered with flesh. When a fat steer moves, the flesh about his breast and in his flanks shows more movement than is seen in a thin-fleshed animal. The hand may also assist the eye in inspecting fat cattle. When using the hand, the ends of the fingers are kept together, and are pressed along the middle of the back and on the sides over the ribs. The thiekness and firmness of covering is easily determined by the touch. A mellow, yet firm resistance to the hand pressure 
should be felt. A common eustom among buyers of fat cattle is also to feel the covering of the end of the rump and the point of the shoulder, and to grasp in the hand the hind flank, which should be low and full in a well-finished beast. A thin, hard eovering at these points shows that the animal lacks in covering of flesh.

The indications of quality in beef cattle are fineness of bone; a silky, heavy coat of hair; a mellow, elastic skin; and

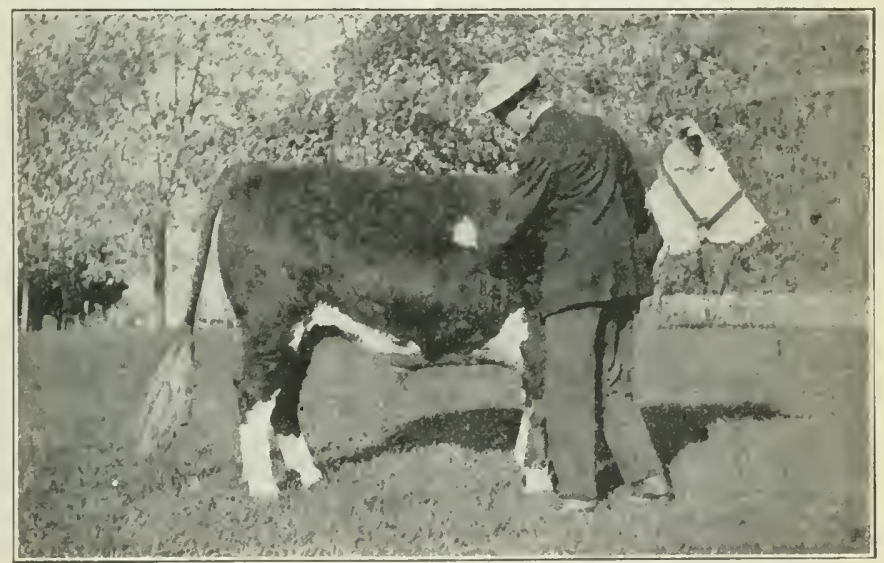

Fig. 101. Ilandling the hide to study thickness and quality. Photograph by author.

refinement, as seen in the head in particular, and in the entire form in general. Large ears, heavy bones and joints, a rard thick skin, and coarse wiry hair are all evidences of a poor digestive capacity and lack of quality. In the ease of becf cattle, smoothness and uniformity of covering are also indications of quality. In the earcass, fineness of grain of flesh and a good distribution of fat particles a mong the fibers are measures of the quality of the meat. If the ribs and back 
have lumps or rolls of fat, and the rump is also rough, then the quality of carcass will be of inferior grade. Such a condition should be easily observable.

A scale of points for fat cattle is here given. This is made somewhat brief, but corers the important features.

\section{A Score Card for Fat Cattle}

\begin{tabular}{|c|c|c|}
\hline $\begin{array}{c}\text { Perfect } \\
\text { score }\end{array}$ & $\begin{array}{l}\text { Stu- } \\
\text { dent's } \\
\text { score }\end{array}$ & $\begin{array}{l}\text { Cor- } \\
\text { rected } \\
\text { score }\end{array}$ \\
\hline 6 & & \\
\hline 10 & & \\
\hline 10 & & \\
\hline 10 & & \\
\hline $\begin{array}{l}\frac{2}{2} \\
1 \\
2\end{array}$ & & \\
\hline $\begin{array}{l}5 \\
2 \\
2\end{array}$ & & \\
\hline$\stackrel{5}{i}$ & & \\
\hline 10 & & \\
\hline $\overrightarrow{2}$ & & \\
\hline 1 & & \\
\hline 1 & & \\
\hline 2 & & \\
\hline 100 & & \\
\hline
\end{tabular}

GENERAL APPEARANCE:

SizE A.ND WEIGHT, score according to age. Example: 12 mos., 550 lbs.; 30 mos., 1500 lbs.

Fors, top and underline straight: broad, deep, compact, low-set, not paunchy.

QCALtTy, refined, as shown by fine bone; mellow, elastic hide; soft, silky hair; clean eut head.

Conditios, deep, even covering of firm, mellow flesh.

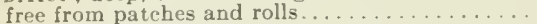
HEAD AND NECK:

IUZzLE, broad; nostrils large; face short ...

EYEs, large and placid: forehead broad

EARS, of medium size and not coarse.

VECK, thick and short, neat at throat

FORE QUARTERS:

SHoclders, well placed, smoothly covered, nicely fitted to neck...

BRISKET, wide showing full breast, not much dewlap BODY:

LEGS, straight, short, wide apart, shank fine .......

СнEst, deep, wide; girth large........

BACK, broad, straight, thick and smoothly lleshed..

LoIs, thick, broad...... thickly and smoothly covered
RIBs, long, well sprung, thich

FLANEs, full

HIND QUARTEIR:

Hips, well set in, and smooth......................
Resr. long, wide, not droopy, nor patchy; til head smooth

THs ss, thick and full; trist plump.

LEGs, well placed, short, straight; shank fine.

In judging fat cattle, either by the score card or otherwise, the general appearance should he first considered. As one walks about the animal, he compares the size with what he thinks it should be for the age, and notes the general form, condition, and quality,-features that have already been 
discussed. Having made this inspection, the next thing will be to consider the detailed features of conformation. Beginning with the head, we seek for evidenees of the good feeder and a pleasant disposition. A broad muzzle, with shortness from this point to the eyes, usually indieates constitution and feeding capacity. A clear, prominent eye denotes a pleasant disposition; and the broad, full forehead, a com-

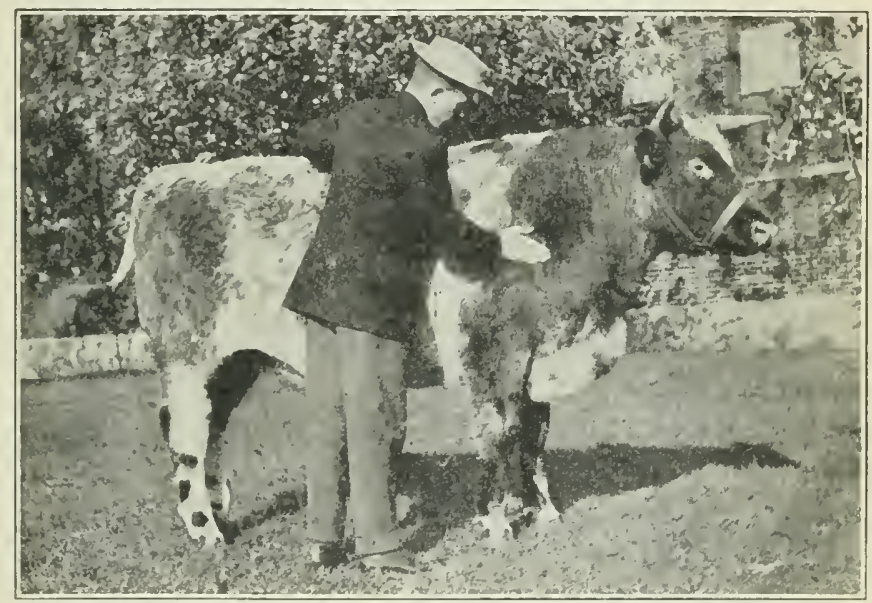

Fig. 102. Examining the covering of flesh over the shoulder. Photograph by the author.

paratively high degree of intelligence. The eye is an important guide to the disposition, and should be carefully eonsidered. The ears are a guide to quality, for if large and thick, and heavy at the base, they indicate coarseness. The reason for desiring a short neck is to reduce the amount of cheap meat. The short, thick neck is also an evidence of constitutional vigor, for it is connected_with a wide, full breast. Back of this should be a capacious chest, with 
ample room for the vital organs. A strong, vigorous constitution is very important with all kinds of stock. One must see the character of neck from the side and top, and may easily note the way it joins both head and shoulders. From the side, one notes the placing of shoulders, their slope and smoothness of covering, the blending of the neck with the shoulder at the so-called "shoulder vein," and the spread between the blades at the

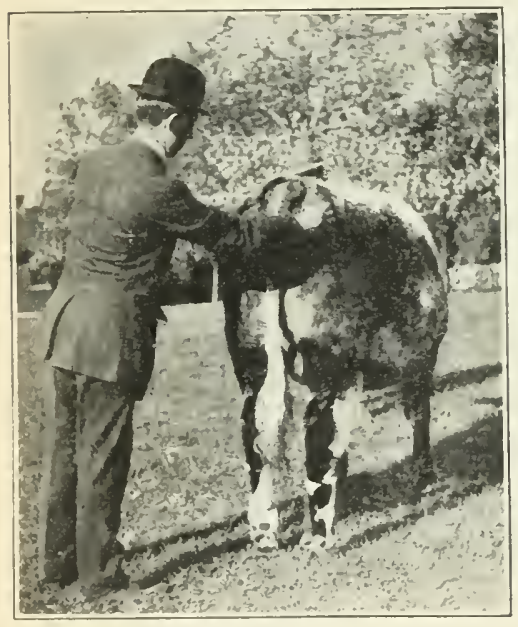

Fig. 103. Inspecting the rump and feeling point of rump to note condition. Photograph by he author. top. The wide spread shoulder top is not desired because it means lack of covering of flesh and indicates a narrow floor of the chest. From in front, the fullness of breast, the carriage of brisket, and length of leg are casily seen. The brisket, being the portion that extends forward between the forelegs, is the sternum proper, and with the best of fat cattle is usually thick and prominent. Begimning at the brisket, extending upward from the front of the neck, is a thin fold of skin known as the dewlap, which is undesirable to have in any great amount. As a rule, the lewlap is not prominent on beef cattle, being more in evidence on lighter-fleshed stock, and in eertain breeds. The front legs should be short, and the feet stand squarely on the ground, the toes pointing straight ahead. The bone just below the knee, known as the shank, which is termed 
the cannon bone with the horse, should be reasonably fine and short, an important indication of quality. When the front legs stand well apart, we usually find plenty of chest capacity. The body of the beef animal requires large size and capacity, the wide back giving room for the valuable cuts already described. Fullness and depth of body also go with the digestive capacity sought for in a good feeder. A study of the body capacity and value should be made from one side and from above the animal, to observe the thickness and spring of rib. Emphasis may be placed on this last feature, for a well-sprung, long rib means thickness and depth of body. Shortness of coupling from the hip to the nearest rib is also important, if we are to have compactness of form. An examination of the hind quarter is made from a point opposite the thigh, and from directly behind. Good length from the hips to the end of the body near the tail, to what are called the pinbones, is important; for here we find large, heavy muscles of very good quality for meat. The longer, broader, and fuller this part, the more flesh one should expect to find. The thighs, which extend to the hocks, should show length and thickness. From a side view, the distance from the point of hip to

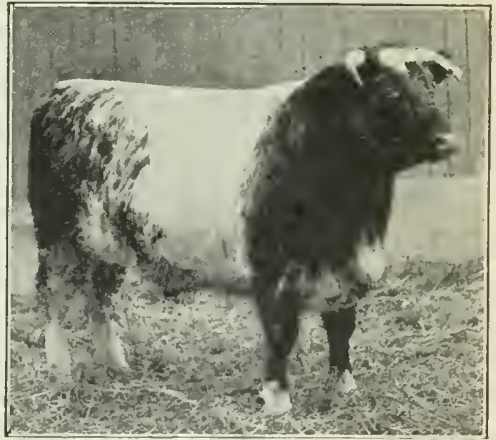

Fig. 104. Roan James, reserve grand champion steer, 1910 International Exposition. Shown by Jas. Leask, of Canada. Photograph by courtesy The Farmer. the hock should be great, with the hind flank appearing low down. From the rear, the thighs should appear thick, and straight of edge on the outer part, with 
the space between filled in full and low. Between, where the thick lower part of the upper thigh meets the lower thigh, is located the twist. On high-class fat cattle, the twist has a very short, wide curve. The poorer the hind quarter from a beef standpoint, the less noticeable the twist. The hind legs, from behind, should appear straight, with the points

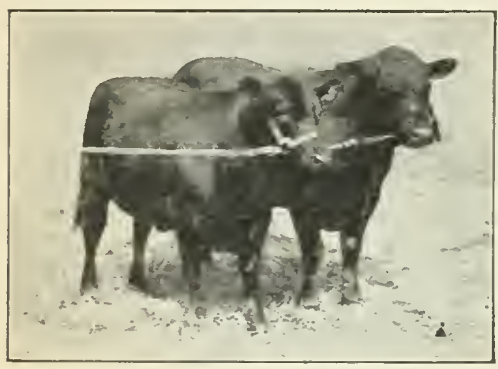

Fig. 105. A front riew of beef cattle, showing breadth of chest. Photograph by courtesy The Farmer. of the hocks well separated and the toes directed straight ahead. If the hocks touch at the points, and the toes turn out, the animal is ealled "cow hocked." This bad position throws the thighs elose together and prevents the desired thickness. It is also important that the shank bones, from a side view, stand nearly vertical, thereby supporting the parts above so as to provide the best conformation.

In judging breeding beef cattle, certain essentials should be kept in mind. Maseuline character of head and neek are important with the males, and feminine features with the females. The head of the bull is usually large, is rougher haired at the forchead and poll, and carries a strong horn, if of the horned sort. 'The neek is also thicker and more erested than with the steer, and the shoulders usually are somewhat prominent, though not necessarily so. The cons have refined heads, with light horns, and the neck is of but medium thickness and length. The udder, also, should show plenty of capacity. In general form of body, breeding eattle should possess the important features already described, but should lack in flesh as compared with fat stoek. 


\section{JUDGING DAIRY CATTLE}

The size of the dairy animal is not material, unless in the case of a breed that has certain size requirements. Among grade animals may be found valuable producers at wide ranges of size. There are large producers in each breed, from the little Dexter, weighing 500 pounds, up to the Holstein, weighing 1800. For this reason, size is of minor importance, if producing capacity and proper conformation exist.

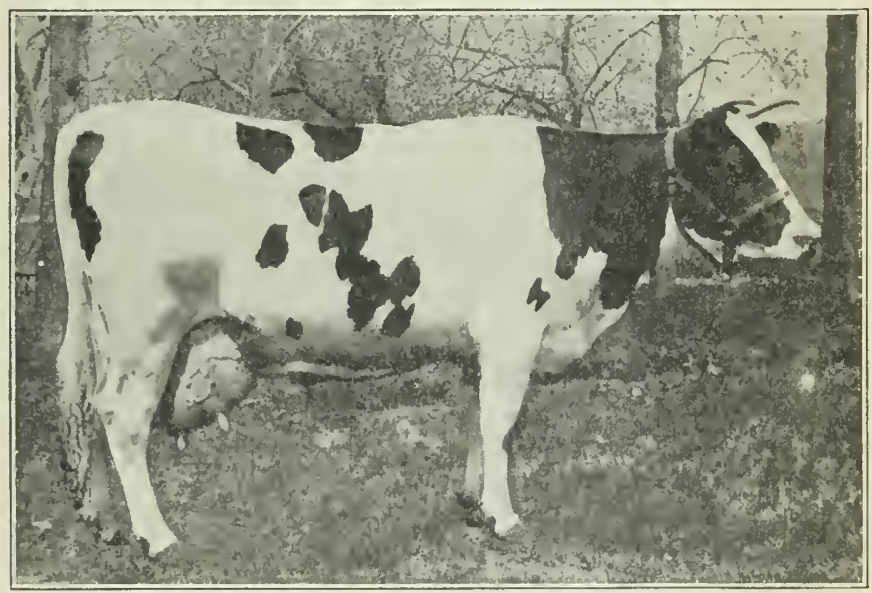

Fig. 106. Daisy Grace DeKol, a famous Holstein-Friesian cow, that shows dairy type. Photograph from the owners, Dimmick Bros., of Ohio.

The general form of the dairy cow should be somewhat wedge-shaped, often referred to as the "triple wedge." This shape really means a narrowness in front and heaviness behind. As one looks at a typical dairy cow from one side, the front part scems less deep than that behind. If a stick of ample length were laird along the back, and another were placed in a similar position against the 
under side of the body, they would meet at a common point in front, if sufficiently extended. Thus we see one of the wedge features. If one stands in front and looks towards the rear of the animal it will be noticed that the thickness through the front quarter at the shoulder is less than that of the hind quarter at the hips or just below. This gives a second wedge conformation. The third wedge is seen by standing at the shoulder and looking down over the withers and ribs. From the withers the ribs gradually widen out to form a noticeable wedge in the upper half of the body. Thus we may see the three wedges in the conformation of the dairy cow.

The general form of the dairy bull shows much less of the wedge shape than the cow. However, the best bulls have a certain amount of thinness at the withers, and the body is long and muscular. The depth at the hind quarter is much the same as at the fore quarter, although the males

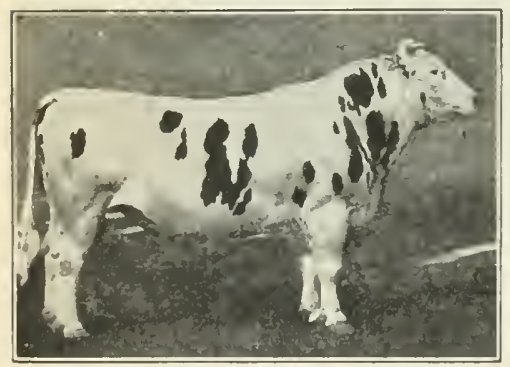

Fig. 107. Sir Beets Cornucopia Netherland. A Holstein-l riesian bull, showing mueh quality and sex character. Photograph by courtesy The Farmer. are frequently somewhat high at the rear flanks. While the thighs, from a side view, appear muscular, as is the case with the cow, from the rear they should be thin and widely and highly separated. A beefy appearance of the thigh in this type is most undesirable.

Quality in dairy cattle has certain features in common with the beef type, such as fineness of hair and bone and mellowness of skin. The chief differenee is in the thickness and length of the coat of hair, which is usually much shorter and thimner on clairy than on beef cattle. The ditiry ani- 
mal, as a rule, has the thimner and more elastic hide of the two. Those cattle that are of Jersey or Guernsey blood, have very mellow, most elastic hides, that sometimes resemble a mole skin in their soft, pliable nature. Yellow color in the ears, skin and horns is regarded as evidence of quality, and indieates the production of milk rich in color. The Guernsey cattle club places such a high value on the color of the seere-

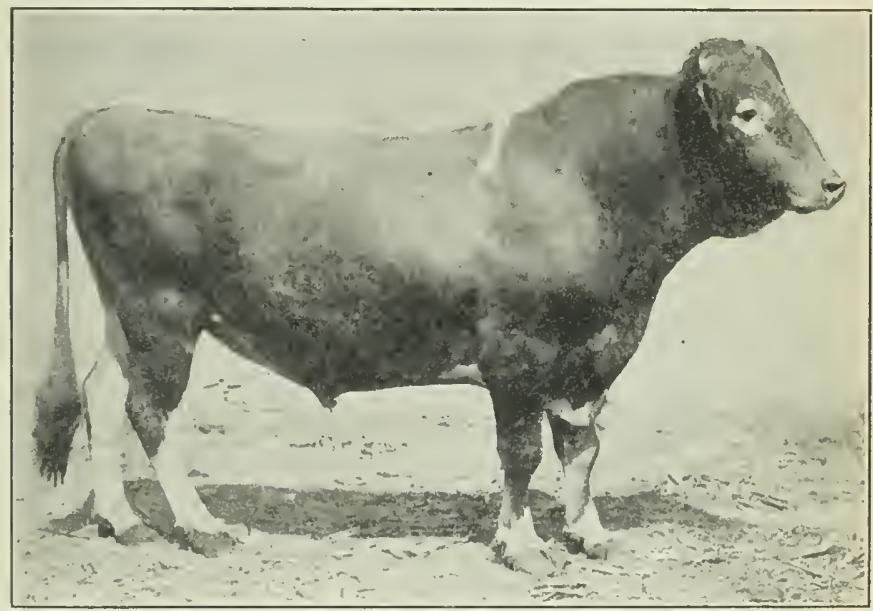

Fig. 10s. Dairy bull type, showing the muscular form and thin thighs. This is Lord Yeksa, a Guernsey bull. Photograph from the owner, J. H. Beirne, of Wisconsin.

tions, that 15 points are allowed this feature in their scale of points.

The temperament of the dairy animal should show plenty of nervous force. This does not mean an excitable disposition, but lively rather than phlegmatic. Dairy bulls usually show plenty of nervous foree, as compared with beef stock. The cow is constituted to produce milk, which requires a large amount of vitality and nervous energy. 
Indications of the temperament are easily seen in the prominence and character of expression of the eye. Some claims have been made that prominence of the spine indicates a large spinal cord and active brain, being a further indication of nervous force. There is very little information on this subject, however, that will justify drawing conclusions.

In judging dairy cattle, beyond what has already been stated, there are certain things to be considered that especially apply to this type, as set forth in the following seore card:

\section{A Score Card for Dairy Cows}

GENERAL APPEARANCE:

SizE, large, medium, or small

Form, wedge shape from front, side, and top; muscular

QoALrT, hair fine, silky; skin mellow, loose; bone fine................................ TEMPERAMENT, active, showing nervous foree. . . . . . HEAD AND NECK:

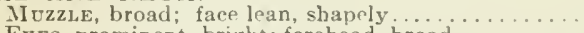

EYES, prominent, bright; forehead broad.

EARs, medium size, not coarse.... .1 ilaced; clean tit
NECK, somewhat long, not thick, well place. throat; light dewlap............

FORE QUARTERS:

SHoclders, light, oblique; whthers lean;

BODY:

LEGs, straight, short; shank fine...........

CHEst, deep, girth large; crops not much depressed

BAck, lean, strong. well defined; ribs long, well sprung LoIs, broad, long, level

Barrel, deep, large capacity, with low flanks....... HIND QUARTIRS:

HiPs, wide apart, not fleshy...

Rump, broad, long, not droopy; pin bones wide apart

TAIL, long, fine; good switch

Tüus, thin, long, wide apart

lEGS, straight, short, wide apart; shanks fine.

MANAIRY DEVISOPMENT:

UDDER. large, earried well in front along the belly, and high up bchind, thick, mellow; quarters even and not much grooved between...

TEATs, 3 to 4 inches long, well placed: an easy milieer

MILK VErs, large, long, tortuous or widling, entering

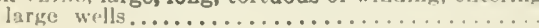


The head should be lean and shapely. In general, the wide muzzle, short face, strong jaw, prominent eye, and broad forehead are desired. In most cases, a "dished" face is popular. This feature is a slight clepression of the head at the lower part of the forehead and between the eyes. Yet all breeds do not have it. The dish-face is very characteristic of the Jersey, but is not so pronounced in the HolsteinFriesian. A broad muzzle, short face, and strong, wide jaw, indicate a vigorous feeder. The eye should be prominent yet show a mild disposition, as indicated by clearness of the whites and quietness of expression. Dairy bulls often have eyes that indicate very clearly their character. The ears should be mediun of size and thin of texture, and be neatly attached to the head. A yellow or orange color within the ear is desirable. The horns, when present, should show refinement,

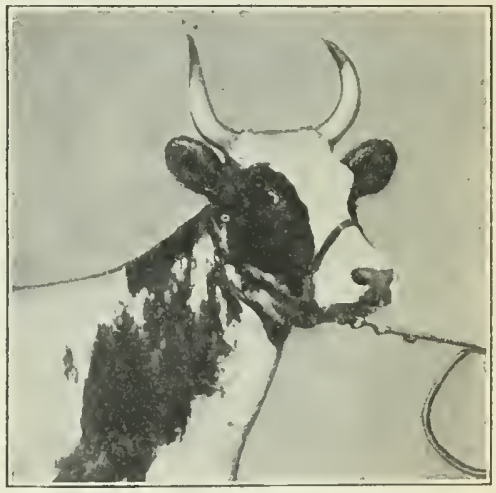

Fig. 109. A type of head of dairy cowThe Ayrshire 1sabella 3d. Photograph by courtesy of C. M. Winslow. and not be large and heavy at the union with the head. A small horn is preferred on the females, and some of the best known dairy sires have had rather small horns. A thin, muscular, somewhat long neck on the cow, and a strong, heavily muscled, rather crested neck on the males, are desirable. When the neck blends well with the head, there is no unnatural fullness at the throat. The union of the neck with the shoulders should also be smooth. Dairy animals 
sometimes have a heary dewlap, which is rather objectionable.

The shoulders of the dairy animal incline to be somewhat prominent and are often rough. This is in most cases due to the lack of covering of flesh. The smoothness of the shoulder found in the beef animal is not to be expected with the dairy type, but the blades should extend well into the back and not be coarse. The withers above the shoulders should be lean and somewhat sharp. In fact, dairy cattle

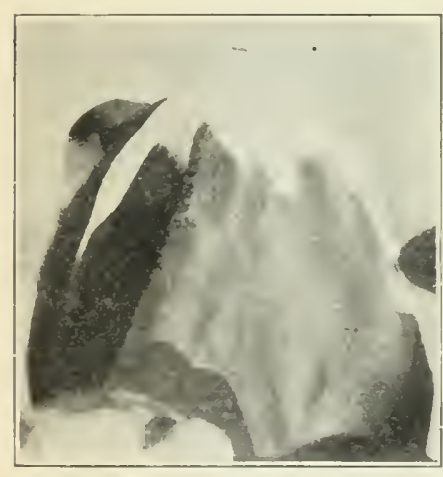

Fig. 110. The withers of the dairy row. Photograph by courtesy of The Farmer. judges place a premium on thin, sharp withers. Many great producing cows, however, have some thickness or fleshiness at this point. Oceasionally, one will find dairy cows with the shoulder points noticeably separated from the body. This is what is called a spread shoulder, and shows a weakening of the muscular attachment. Such a cow has an undesirable appearance, but otherwise is not seriously affected.

The body of the dairy cow should be deep at the chest, yet not thick. As one views the animal from one side, the depth from the top of withers to bottom of the chest should be much greater than the length of leg. From a front view, the chest appears somewhat narrow. Not much depression back of the shoulders below the withers, at the point known as the "crops," is desired, for this indicates weakness in heart girth. 'The same criticism will apply at the fore flank. The back should be well and strongly carried, with the spine 
easily seen above and beyond the shoulders. A strongly arehed rib will give a wide back and a muscular loin, which are most desirable, while plenty of additional length of rib will mean ample digestive eapacity. In examining the bodly with the hands, one should be able to place two fingers held side by side easily between the last ribs of mature dairy

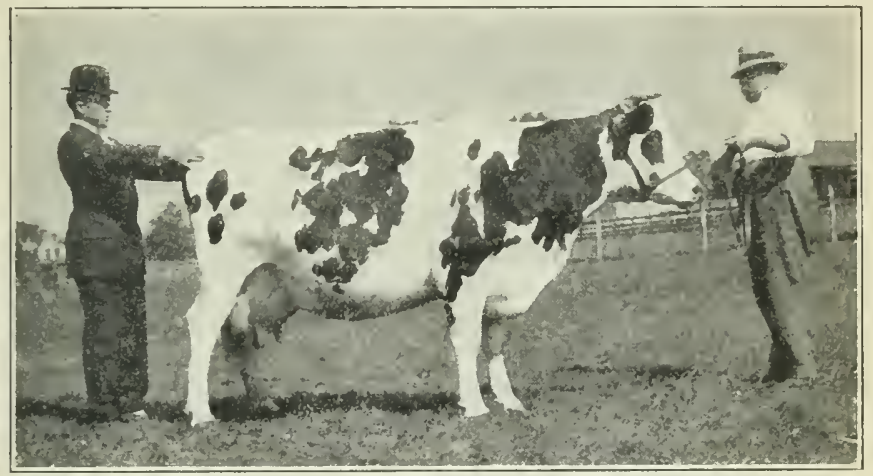

Fig. 111. Looking along the top of body to note conformation. Photograph by th: author.

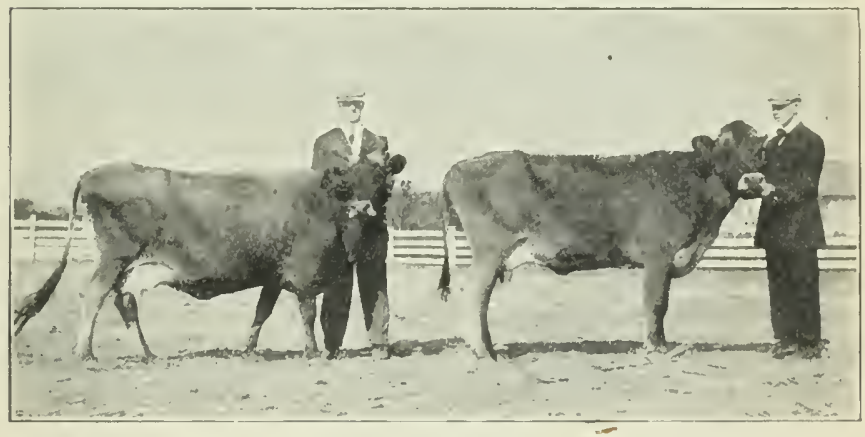

Fig. 112. Two Jersey cows, one showing enstitution and depth of body, the other a short rib and poor feeding eapaeity. I'hotograph by the author. 
cattle. The opinion prevails, that with dairy animals there should be length of body with the ribs less closely placed together than is the case with beef cattle. Consequently, a body of considerable length meets with favor. Some juclges prefer the hind flank to be somewhat high, but this is associated with lack of depth of body, signifying a deficient digestive capacity.

The hind quarters of the dairy animal have been the cause of much discussion. The hips of the cows should be somewhat prominent and lean. With the males, less prominence

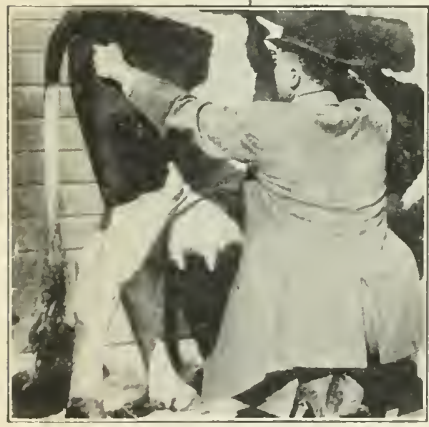

Fig. 113. Showing length of rump of the dairy cow. Photograph by courtesy The Farmer. of hip is desired. In the case of each sex, much length and breadth, with level carriage of rump, is wanted. Below this part, the thighs, as viewed from one side, should appear muscular and long. From the rear view, the thighs should seem thin, and placed wide apart, giving ample room between for a large udder. We sometimes say that the thighs are incurving, which means that from the point of the rump or pin bone, each thigh curves slightly for a distance towards the body before curving outwarl to form the top of the hock. The tail should have a neat placing on the body, and its fleshy part should hang in a perpendicular position to the hocks, showing considerable space between it and the thigh as viewed from one side. A beefy character of any part of the hind quarter is very undesirable. The tendency is to show fleshiness at the top of the rump over the hips and pin bones, and on the thighs. $\Lambda$ straight, wide carriage of 
the legs is most essential, as has already been explained and as will be brought out further on.

The mammary development of the cow includes the udder, teats, and milk veins and wells. It is necessary to examine this part careiully with both eye and hand.

The udder consists of two large glands suspended between the legs. One gland is the right half of the udder, and the

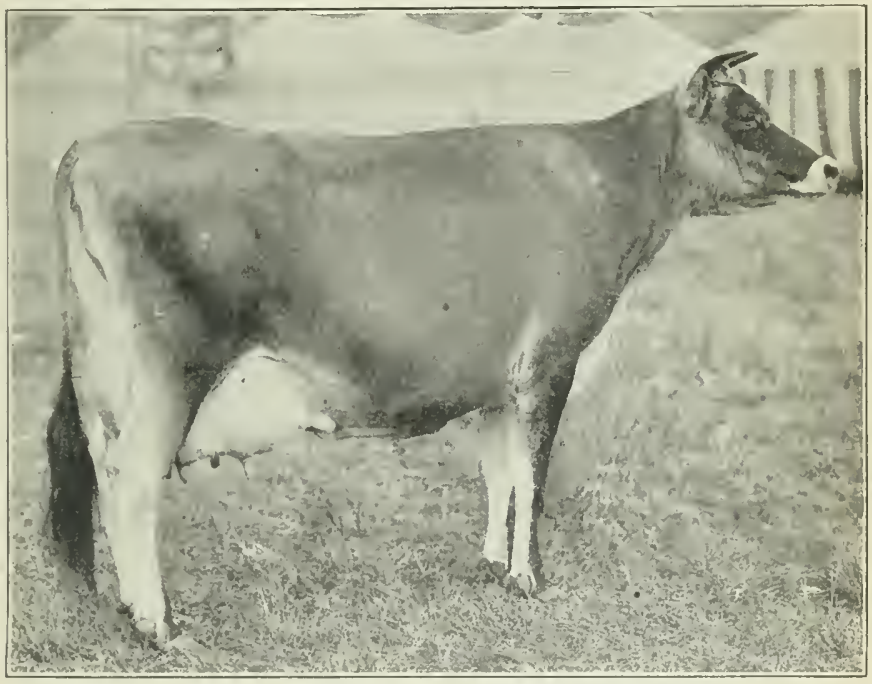

Fig. 114. A beautiful udder on a great show cow of dairy type-Bosnian's Anna, Jersey champion for 1910 . C. I. Hudson, of New York, owner. Photograph by courtesy Prof. F. R. Marshall.

other the left. Each gland is also divided into two halves, known as quarters. As we view the udder at one side, we see the front and hind quarters of the gland. The form of udder that is most approved follows the line of a circle in part, although we look for the rear portion to be carried up high beyond the line of the eirele, and the fore part to extend 
well along under the belly, on a uniform level. Therefore these udder lines above and below prolong beyond the circle. Viewed from the rear, the udder should appear thick, and should occupy completely the space between the thighs, and extend up high along the thigh. Examination with the hand should show no deep separation or division between the glands or quarters, but only slight grooves. As a rule, the hind udder is somewhat narrower than the fore udder, due to the limited space between the thighs. Thus

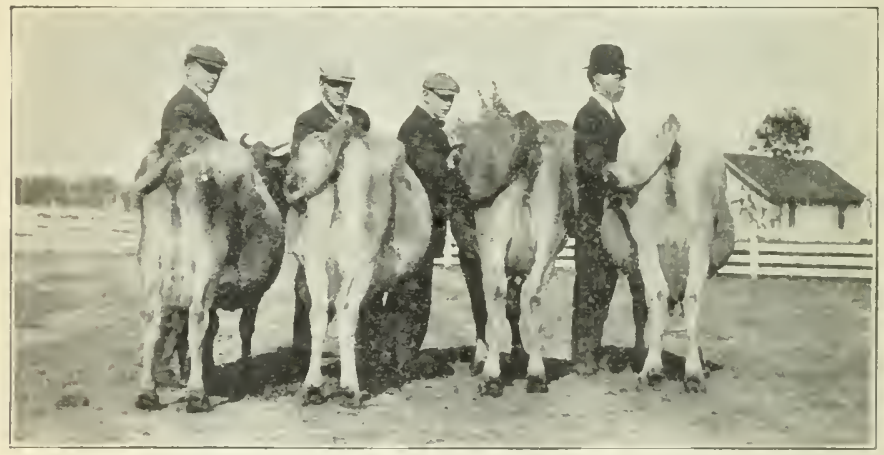

Fig. 115. Four hind-end presentations, showing good and bad placings of legs. - Photograph by the author.

one may see the importance of having the thighs widely separated to provide room for the udder. The teats should be of convenient size for grasping by the arerage-sized hand, and a length of three to four inches is satisfactory. They should be placed at a fair distance apart, such as will permit of easy milking, without the hands being in the way of each other. 'The judge should examine each teat carcfully, and see that it milks without difficulty, and is all right. The form of the udder is rather variable. The most common weakness is an inferior front development, with the teats of 
this part placed much higher than those behind. The smaller the fore udder in comparison with the hind part, the less its producing capacity. With age, the udder frequentiy becomes pendant; that is, hangs low down. This is a special feature of those cows that become heavy milk-producers. In acting as a judge in the show ring, one may find it desirable to request that certain cows be milked. Some cows have meaty udders of quite limited capacity, and to make a fair study of this gland, one should see it both full and empty. When empty, the glands should be considerably shrunken, and

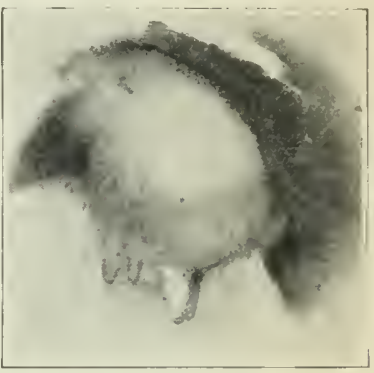

Fig. 116. A very common, poor kind of udder, with inferior fore-quarters. Photograph by the author.

when pressed by the hands, should feel uniformly mellow and smooth to the touch. The judge should take it in

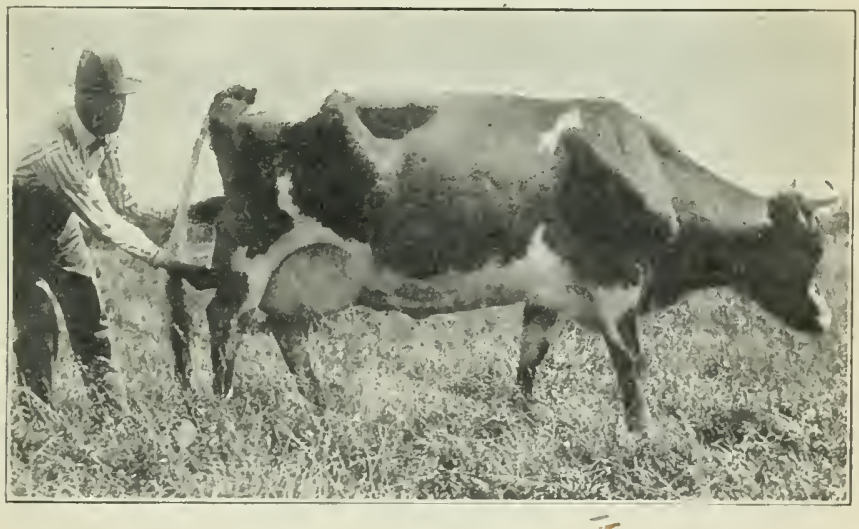

Fig. 117. Notice the elastic hind udder held by the man. Photograph by the author. 
his hands and press it between the palms, and examine it generally as to its condition, noting whether smooth of tissue, or if lumps or knots occur. Again, examination may show imperfect quarters or defective teats.

The milk veins are located along on the belly from the udder forward. Usually there is one vein on each side, and sometimes a shorter one between. Through these veins the blood passes from the udder to the heart. A side view of the cow shows something of the vein on that side. On young cows it is smaller and less prominent than on old ones. It varies in size, length, and form. To examine it carefully, it is

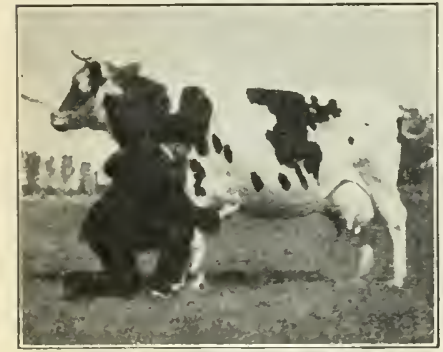

Fig. 11S. The milk well at end of vein. Photograph by the author. necessary to bend over enough to look up beneath the body and see the whole milk-vein system. Usually the vein is about five-eighths of an inch wide, and after extending along the belly half way or so from udder to fore legs, disappears through a hole in the belly wall, known as the "milk well." Sometimes the veins are very large and long, and have a more or less tortuous, or serpentine course. The larger and longer the veins, the greater the cow as a milker. Sometimes we find the belly immediately in front of the udder covered with small veins, and occasionally they also occur on the udder. All these small veins are indications that the cow is more than an average milk producer. The milk wells vary in size, from those so small that they are not at once discovered, to those so large that the end of the finger can easily be placed therein. We really know nothing about the value of the reins or wells, from a scientific point of view, as indi- 
uating milk production, but practical experience has rated them as important according to their size and development. Small wells are associated with similarly small veins, and together they limit the supply of blood passing through the udder and thus affect milk production.

\section{SUPPOSE SOME ONE SHOULD ASK YOU}

1. What is meant by a "blocky" body?

2. How you could tell whether a beef animal was fat or not?

3. To give the indications of quality?

4. How much a beef animal should weigh at 30 months old?

5. To describe condition?

6. What position the front legs should take, and why?

7. How the head and neck of the bull differ from those of the cow?

8. To describe the triplewedge form?

9. The meaning of temperament in dairy cattle?

10. To give the most important features of the dairy cow score card?

11. What kind of rib development should be looked for in the dairy cow?

12. To describe the most desirable form of udder?

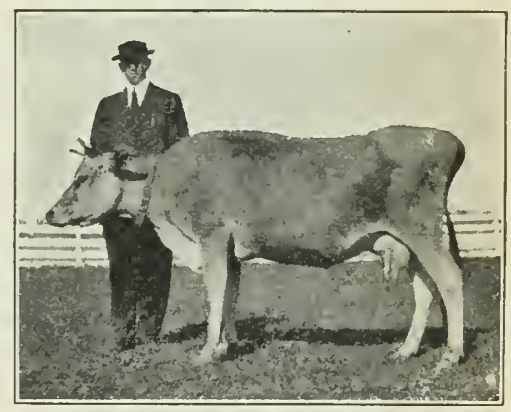

Fig. 119. The kind of cow one should not own. Photograph by the author.

\section{SOME INTERESTING THINGS TO DO}

13. Scoring your own or a neighbor's beef animals.

14. Picking out the best individuals among cattle in a feed lot.

15. Comparing the best and poorest dairy cows in the herd. Why is one best and the other poorest?

16. If you have a dairy herd at home, make a few group studies of four animals in each.

17. Organize a local beef or dairy cattle show. 


\section{CHAPTER XI \\ THE JUDGING OF SHEEP}

The catching and holding of a sheep for inspection is usually a simple matter if correctly done. To cateh the sheep, seize a hind leg at the hock or flank and gently pull

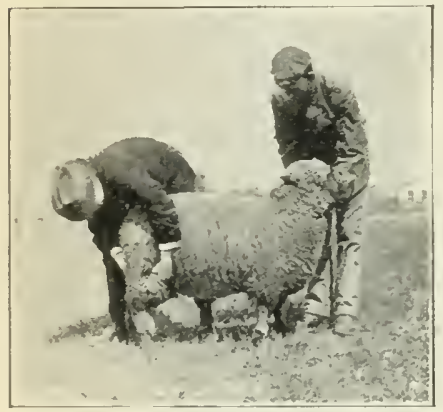

Fig. 120. Examining the leg of mutton. Photograph by the author.

him to the location desired. Never grasp and pull the wool, for the more the fleece is pulled the harder the sheep will struggle to escape. Next place the left hand below the jaw, palm up, and quietly hold the head and throat, and then reach back to the right hind quarter with the right hand and pull the sheep squarely in front of one's legs and close to the body. If it is desired to move the sheep forward, it will only be necessary to press gently forward with the right hand. If that is not enough, then place the finger tips at and beneath the root of the tail, and the sheep will move forward without trouble. Sheep that are accustomed to handling, as a rule, may easily be held by placing the left hand under the lower jaw, and holding the back of the head or neck with the right hand. In judging-work at a school, a small rope halter will be found useful in simplifying the matter of holding and the use of attendants.

To examine the under side of the sheep, it is desirable sometimes to place the animal on its rump. To do this, one 
should pass the left hand under the neck and grasp the right forearm. Then reach forward and under the sheep with the right hand and grasp the right hind leg at the hock; by a slight pull of the right hand, and a push of the body against the sheep, the animal will naturally swing down upon its rump. When in this position, the sheep is held with the left hand, with the sheep's back resting against the holder's knees. This operation becomes easy with a little practice.

How to study the sheep. During much of the year, except for a short time after shearing, perhaps, the boclies of sheep are covered with wool. This varies greatly in length, but is frequently $31 / 2$ to 4 inches long. With this covering of wool, it is impossible to juclge the merits of the animal, except with the assistance of the hands; for the fleece covers defects that may be felt, but not so readily seen. Men who exhibit sheep usually trim the wool, or block it out, as it is termed, so as to make the animal look very symmetrical and attractive. While one should survey the general appearance of the sheep, as in the case of other animals, the use of the hands is an added necessity. While examining a mutton sheep, one should keep the fingers of each hand close together, and then press them flat on the wool, not allowing single fingers to stick into the fleece. It is important to

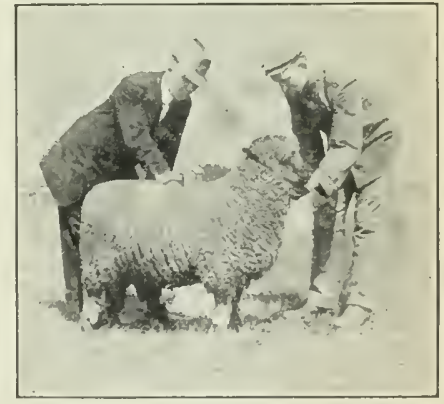

Fig. 121. Studying the thicknesy of flesh over the back. Photograph by the author. prevent the entrance of dirt, not to open the fleece, except at places where it naturally parts or breaks between two locks. The back wool, especially, should be kept closed. 
With the fingers one may press the wool firmly enough to feel the flesh below, to determine the extent and uniformity of fattening or covering over the frame, and whether the wool hides defects of conformation, such as narrow back, droopy rump, etc. Practice, of course, enables one in time to use the hands with much freedom, without detriment to the fleece, but inexperienced persons should be very careful not to disturb the wool. The skin of a sheep should be of a healthy pink color. It is assumed that this indicates the animal to be in fine physical condition. However, some breeds that are noted feeders, like the Shropshire and Oxford, have dark-colored skins often times, and so it may be said that we do not know the real significance of skin color. Yet the skin in any case should look clean and healthy, and not pale and bloodless.

The age of the sheep is easily determined up to four or five years. A short time after birth, the lamb has in the front of the lower jaw, eight small, narrow teeth, which are commonly called the milk teeth. The front part of the upper jaw has no teeth, but simply a tough, fleshy pad. When about 12 months old, the two middle milk teeth drop out, and two larger, permanent teeth occupy the place. At about 24 months, two more teeth push out two milk teeth, one on each side of the two that came in at 12 months. At 36 months two more come in, and at 48 months the corner tecth are replaced by larger permanent ones. It is easy to tell the age up to four years. After that one must do some guessing. It is to be noted, however, that with age the teeth usually wear down or break away in the middle first; old tecth also slant forward more than do those of less age. It is a good plan always to examine the teeth when judging or buying; for they are a guide to age, and indicate the condition for feeding and future usefulness. 
A systematic inspection of the mutton sheep should take place after the following manner. So far as conformation is concerned, look for the same blocky, fullness of form that would be expected in a fat steer.

1. Survey for general appearances in the usual manner as previously described with horses and cattle.

2. Rest the lower jaw of the sheep in the left hand, and place the right about the back of the head or upper part of neck. Then raise the point of the jaw somewhat, and part the lips gently by use of the forefinger and thumb of the left hand. This enables one to inspect the front teeth, which are found in the lower jaw only.

3. Inspect muzzle, face, eyes, forehead, and ears.

4. View the breast and position of fore legs while standing in front.

5. With the right hand grasp the neck and feel for its size and attach-

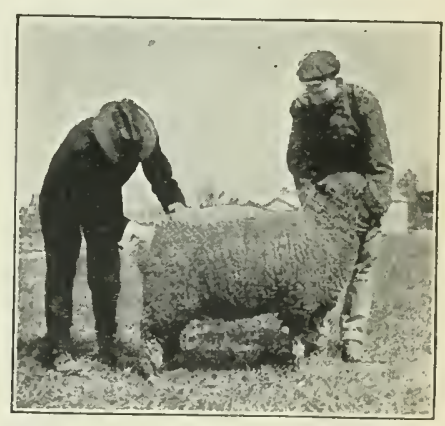

Fig. 122. Feeling for covering of flesh about the tail-head. Photograph by the author. ment at the head.

6. Notice the union of neck to shoulders, the covering of the latter and the position of the blades.

7. Place the right hand on the back, just behind the withers, and the left hand between the legs, on the floor of the chest. This gives one an estimate of the depth of body.

8. Press the hands on the crops and front flanks, to determine thickness of chest. 
9. Press firmly along the back with one hand, the fingers pointing in the direetion of the neck, to determine the covering of flesh. With both hands get the breadth and covering of back and loin.

10. Place the fingers of the hands over the hips and note their covering and distance apart.

11. After examining the hips, draw the hands down on to the rump, and feel its length, breadth, position, and covering of flesh. With the right hand, grasp the

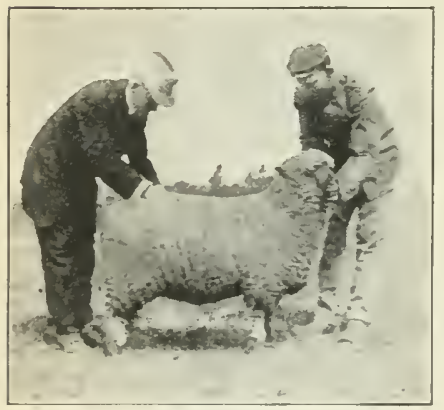

Fig. 123. Examining the width of loin. Photograph by the author. point of rump and note the width, position, and covering of root of tail.

12. Grasp the thigh, usually termed leg of mutton, with the hands, the left hand with open thumb taking in one side of the leg, and the right hand and open thumb grasping the other side. Thus by frcely moving the hands about the leg, one may determine fullness of hind flank, the thickness of muscle, fullness of twist, and size of leg.

13. Place the left hand on the rump at tail and right hand between the thighs at the twist, and estimate the (lepth of hind quarters.

14. With the palms of the hands facing each other, press against the outer thigh, to determine thickness of hind parts.

15. Step back a few fect and notice position of hocks and placing of hind legs and foct.

16. lirom onc side, view position of legs and fert. 
In the examination of fat mutton sheep, no great emphasis is placerl on the covering and kind of wool. The butcher values the wool, but in buying, it receives slight attention. In the show ring, most mutton judges examine the wool of fat sheep scarcely at all. If judging breeds, then the wool must be examined as well as the frame and covering of flesh. Seven points are allowed wool in the following score card for fat sheep.

\section{Score Card for Fat Sheep of Mutton Type}

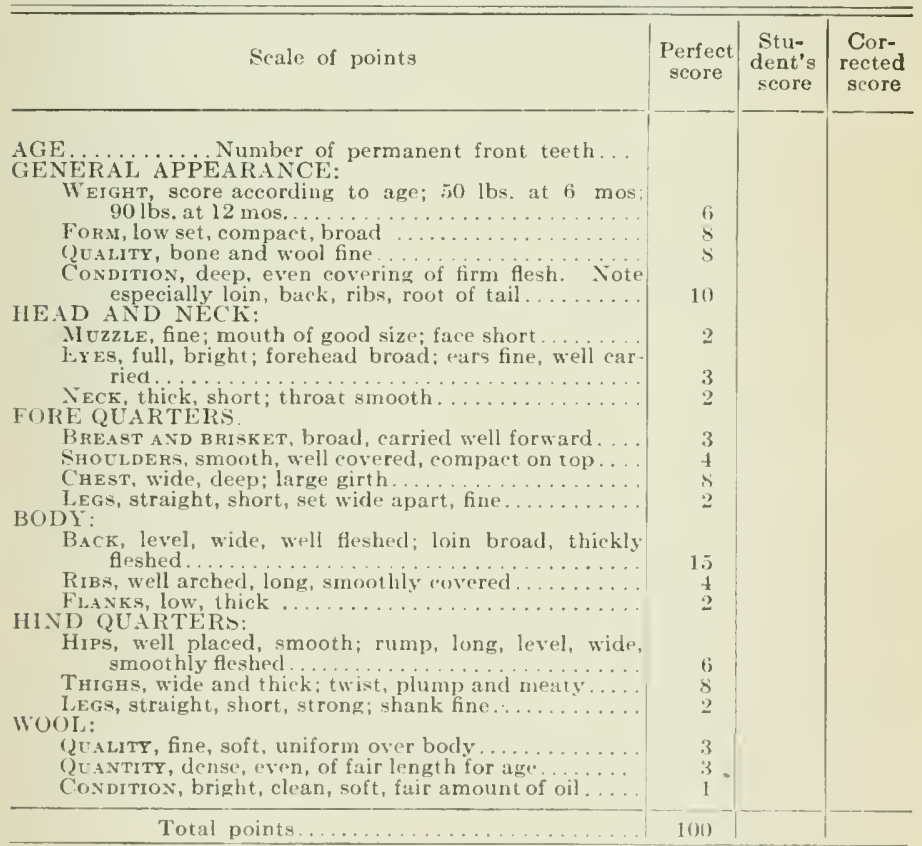

The study of the wool or the fleece on the body of the sheep makes it necessary to know something of the differ- 
ences in this product. Wool is a fiber, much like common hair, and grows in the same manner. On the outside of each wool fiber is a covering of transparent, slightly overlapping scales. Their position has often been compared to the lapping of shingles on the roof of a house. The eenter of the fiber is either hollow or has a porous eore. When the wool is dyed, the dye gets under the scales and inside the tube and is absorbed. True hair does not easily take a dye. Frequently hair is found in fleece and is called kemp. Kempy wool is very inferior and cannot be dyed. Wools differ much in length and diameter of fiber. The Merino has the finest wool, and usually the larger the sheep and the more of a mutton type, the coarser the fiber. The fine wool is more compact over the body than the coarse, long wool. The more dense the fleece, other things being equal, the more it will weigh. A compact fleece also keeps out rain, snow, and dirt better than an open one. The best and longest wool on the body is found over the shoulder and ribs. The back and neck wool also ranks high. That on the belly is very fair but short, while that on the thighs is the poorest. The finest wools are the shortest; and the coarsest, the longest. The fine wool of the Merino is used in making choice dress goods; the fleece of the medium sort, such as the Shropshire produces, makes fine dress goods also; while the coarse, long, or braid wools are used in making horse blankets, earpets, etc. Wool should be of uniform quality over all the body. Quality is shown in its fineness, softness, uniformity, and color. A clear white, with a shading of creamy color, and with considerable of what is called crimp, is most valued. The crimp in wool is a wavy form like the edge of a very finetoothed saw, that gives elastic strength to the fiber. The choicest fine and medium wools show more or less of this quality, but in the long, coarse wools, the crimp is long and 
wavy and often entirely lacking. There is considerable cil in and on the wool. Most of this comes from little oil saes, or glands, in the skin at the base of the wool fibers. The oil comes fl:m the glands and gradually works up to the end $\mathrm{cf}$ the wool fiber. On some kinds of shecp, like the Merino, the oil accumulates dust and dirt until it appears black and dirty on the outside of the fleece. This oil adds to the quality of the wool, but it is not desirable to have it in large amounts, be-

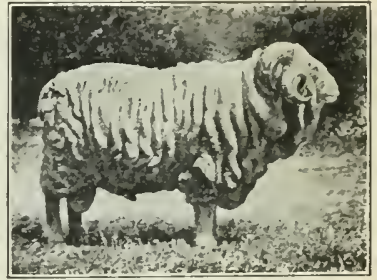

Fig. 124. A Class A Merino ram. cause it increases the shrinkage when the fleece is scoured; that is, when the oil and dirt are removed. Some Merino fleeces lose 65 per cent or more in scouring, while a Shropshire may lose but 45 per cent, a very important difference, since buyers pay for wool on the basis of its weight after scouring.

\section{SOME FEATURES OF THE FINE-IVOOL SHEEP}

Three distinct classes or types of fine-wool sheep are recognized today in the United States. These are as follows:

Class A, with heary folds on the neck, breast, sides, rump, and thighs, and sometimes over the back.

Class B, with a few folds on the neck, shoulder, and thighs.

Class C, with no folds, except in a slight way at the brisket.

The present tendency is to breed sheep of either B or C class. The Delaine Merino and Rambouillet belong to these two classes, with the large majority of individuals in 
Class C. The sheep in Class I have the shortest, finest, oiliest, heariest fleece; while in the C class we find a much

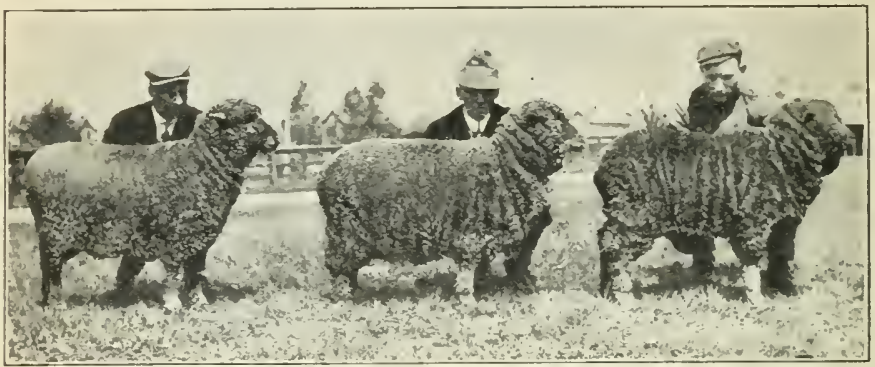

Fig. 125. Three types of Merinos: A on right, C on left, B in center. Photograph by the author.

longer fiber and decidedly less oil, and but little black grease on the surface. A mutton form is also a feature of the Class (' sheep.

The method of judging fine-wool sheep is somewhat different from that of the mutton type. In the case of classes

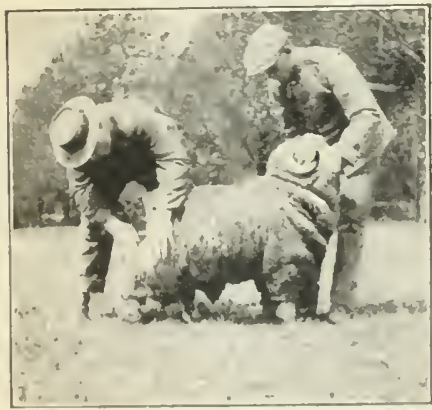

Fig. 126. Lxamining clasacter of wool of thigh. Photogruph by the author.

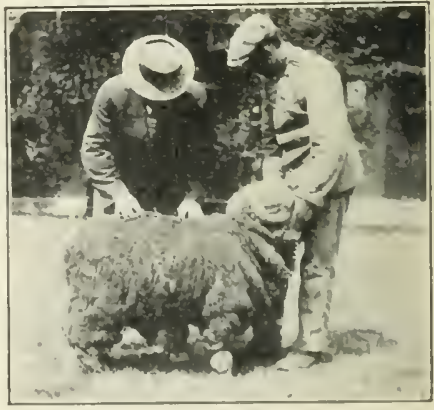

Vig. 127, Insperting open locks on bark of Merino. ['lotograph by the autlior. 
$\mathrm{A}$ and $\mathrm{B}$, the hands are scarcely used, excepting to part and inspect the wool on different parts of the body. In other words, the hand serves only in studying the fleece. In examining this, the locks should be separated on the shoulder, back, and thigh, and compared in length, quantity, and quality. With the hands one may frel to determine the softness and density of covering. Density may also be seen with the eye, as shown in the covering of the head, the belly, and legs, as well as in the general appearance of the outside of the fleece. When wool production is of special importance, examinations of the bare spots on the belly next to the legs, and the general under covering, are essential. This requires placing the sheep on the rump. This position allows not only the wool covering to be studied, but the fullness of breast and the condition of the feet may also be noted. In the examination of the fine-wool fleece, look for a light-colored oil that should be evenly distributed throughout the fleece.

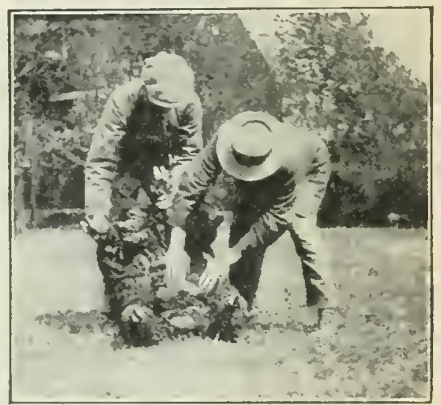

Fig. 128. Inspecting belly wool. Photograph by the author.

Quite often the oil accumulates in spots or streaks, giving an uneven character to oil distribution. This feature is most likely to happen with fleeces containing a large amount of oil.

The score card for the Delaine or Class C Merino is herewith given, and contains the seale of points that can be most commonly used with fine-wool sheep. 
Score Card for Delaine or Class C Merixo Sheep

\begin{tabular}{|c|c|c|c|}
\hline Scale of points & $\begin{array}{c}\text { Perfect } \\
\text { score }\end{array}$ & $\begin{array}{l}\text { S u- } \\
\text { dent's } \\
\text { score }\end{array}$ & $\begin{array}{l}\text { Cor- } \\
\text { rec ed } \\
\text { score }\end{array}$ \\
\hline 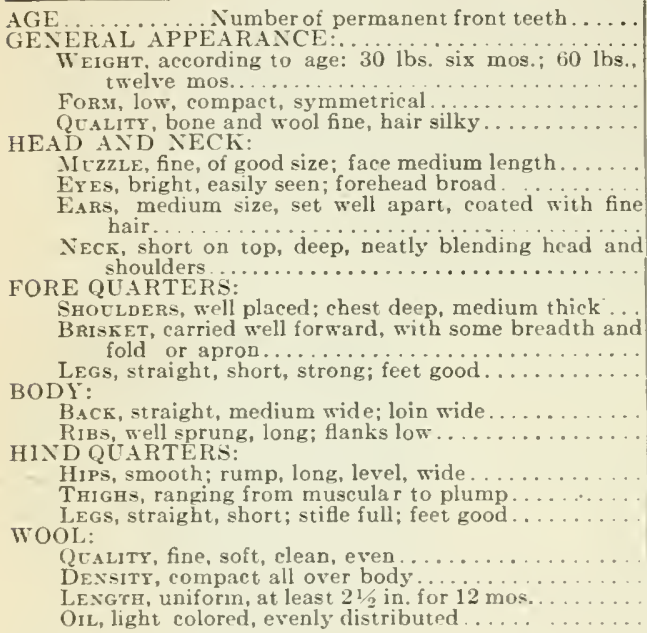 & $\begin{array}{r}4 \\
9 \\
10 \\
2 \\
2 \\
2 \\
2 \\
3 \\
8 \\
2 \\
4 \\
6 \\
4 \\
5 \\
3 \\
4 \\
10 \\
9 \\
9 \\
4\end{array}$ & & \\
\hline 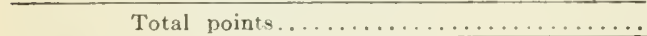 & 100 & & \\
\hline
\end{tabular}

Much has already been said regarding the features of sheep involved in the use of this score eard. In judging this type one must consider the form as approaching very closely to that of the ideal mutton sheep. The fact is, the C type is a general-purpose Merino, with mutton an important feature. Yet one need not expect to find as much thickness of chest, breadth of back, fullness of quarter, or eovering of flesh, as with a Southdown or other more highly developed mutton breed.

Things to emphasize in a study of the Class $\mathrm{C}$ type.

1. The head should be short and broad at forehead, with a slight dish of face in the ewes, and a fullness of nose 
with the rams. Slight wrinkles often occur over the nose, which should be covered with fine, silky hair. The ears also should have a covering of fine hair. Excepting the muzzle, nose, and ears, the head should be well covered with wool. Bareness of the face is objectionable.

2. Favor shortness of top of neck, with no heavy folds below.

3. The tendency is towards narrowness at the withers and fore ribs. Thickness is desirable here, with not too prominent a shoulder.

4. A peaked, droopy rump is a common Merino characteristic, but is very objectionable, and should be severely scored.

5. Look for a thick leg of mutton.

6. See that the hocks are straight, and that the sheep stands well on all four legs. Defective position is frequent here.

7. Merino sheep have poorer feet than any other breed, and require careful attention. The toes frequently grow to one side or are too long, and the horn grows under so as to give the foot a bad position.

In judging breeding sheep of any class, the same essential features must be considered that have already been discussed.

A heavy condition of flesh is objectionable, a muscular animal in good health being most clesirable. Sex affects the character of head and neck. With ewes, some length and refinement of these parts must prevail, while rams must show a larger, heavier, bolder type of face and eye than the ewes, and a thick, muscular neck. The Merino rams, as a rule, have heavy horns at maturity, while the females are 
hornless. With Dorset sheep, the ewes have a slender, onecurve horn; while the rams have a heavier, different type of horn, of spiral form. Hardly as much compactness is sought with breeding sheep as with those for fattening purposes.

\section{IN MAKING A STUDY OF SHEEP}

1. How should the animal be eaught and held?

2. What is the correct method of examining the fleece?

3. How do you use the hands in determining covering of flesh?

4. Describe the method of inspecting a leg of mutton.

5. Where on the body are the different grades of wool found?

6. Describe classes A, B, and C.

7. How should the fine-wool type be examined?

8. How do the scales of points of mutton and fine-wool sheep especially differ?

9. What kind of defects of the feet may occur with the Merino?

10. How do breeding sheep differ from others in character?

\section{SHEEP ARE INTERESTING ANIMALS TO STUDY}

11. Tse the score card at home if you have sheep.

12. Compare several animals on the following points:

(a) The sex character shown in head and neck.

(b) Amount and quality of wool.

(c) Covering of flesh.

(d) Thickness of chest.

(c) Character of rump and hind legs.

13. In shearing season, judge one or more animals before, and again after shearing. 


\section{CHAPTER XII \\ THE JUDGING OF SWINE}

Two distinct market types of hogs exist in America, the lard and the bacon. The lard type prevails in all those sections of North America where corn is an important farm crop. In fact, the bacon type is produced in but a small way in this country, and comparatively few are found in the market. Therefore the study of the lard type should receive most attention. There are, however, with each type or breed of hogs, certain things in common to be especially desired. Some of these are the following.

Quality in hogs, as in all other animals, is of great importance. This is shom in the condition of the hair, the size of bone, and the development of the head. There should be a plentiful coat of hair that is neither very fine nor very coarse. If too fine, lack of constitutional vigor is indicated; but if the reverse, with heary bristles along the back, then a coarse-grained, low- showing quality. Photograph by the grade of killing hog may be lï. 129. I Chester White looar,

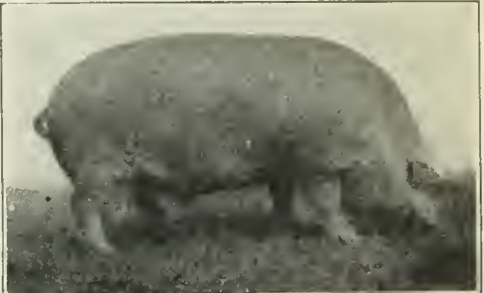

expected. The quality of the hair is an index to the quality of bone. Coarse hair naturally goes with coarse bone. Among experienced swine breeders, a bone of fair size, yet not coarse, is especially desired. The well-fattencd hog requires strong bones to support the heary body weight.- A common criticism today is that of too small a bone and poor support of 
the body. For this reason, many breeders and feeders are looking for a hog that has plenty of size and bone, without coarseness. In passing judgment on animals of this class, one must be mindful to secure as much size as possible, con-

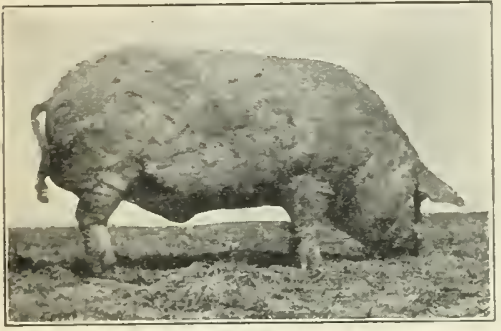

Fig. 130. A Chester White boar showing coarseness of hair. Photograph by the author. sistent with quality. A large head for the body, with coarse, thick ears, also indicates inferior quality. Many young hogs are too small and refined for their age, and never mature into animals of enough feeding or breeding capacity. Therefore excess of re-

finement is to be avoided.

The weight and size of the hog depend naturally on the age and breeding. In the general market, animals that weigh about 250 pounds are most satisfactory for slaughter. The average weight of the millions of hogs sold in Chicago stock yards is about 225 pounds. However, the market demands different hogs for different uses, so that all market hogs are sorted somewhat on the basis of weight, condition, and purpose. For this reason, a criticism regarding weight should take into consideration the speeial purpose involved. At 12 months of age, when fairly well fed, a fat hog should weigh from 300 to 350 pounds.

The condition of the hog refers to its covering of flesh. This should be uniform and smooth, no matter what the purpose of the animal. One common defect, more especially of the lard type, is the prevalence of seams, or creases, on the body. These are particularly noticeable about the neck and the fleshy part under the jaws, known as the jowl, and 
along the shoulders and sides. These creases contain more or less hair that is hard to remove after scalding. In the larger hog killing houses, the hair is removed by automatic scrapers. It can easily be seen that the more creases there are on the body, the more difficult it will be to remove the hair from them. In such cases hand work is necessary to finish the job. These seams are also an indication of uneven fleshing.

The pasterns of the hog are often very weak and sloping. At the back of the leg, just above the pasterns, are two small toes that are known as dew claws. When the pasterns are too sloping, these dew claws often touch the

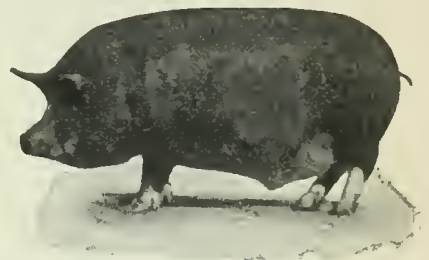

Fig. 131. A Berkshire barrow, showing good condition for killing. ground, showing a weakness of leg. In the days when hogs were driven overland to market, it was very important that the legs should be strong, capable of endurance, and weak pasterns were then very objectionable. While we do not drive hogs much today, it is still necessary in many localities; and whether driven or not, the hog should stand up strong on its toes on short pasterns, as an evidence of ability to carry its weight well. If it cannot do this, then the pasterns are weak.

The toes of the hog should be close together, and point directly forward. Sometimes they are weak and spread apart and do not have a strong position. Such feet are an indication of lack of bone and too much forced growth of the young pig.

A score card for the fat hog follows, which may be used with either the grade or pure-bred animal.- 
Score Catrd for Fat Hogs. Lard Type

\begin{tabular}{|c|c|c|c|}
\hline Scale of points & $\begin{array}{c}\text { Perfect } \\
\text { score }\end{array}$ & $\begin{array}{c}\text { Stu- } \\
\text { dent's } \\
\text { score }\end{array}$ & $\begin{array}{l}\text { Cor- } \\
\text { rected } \\
\text { score }\end{array}$ \\
\hline 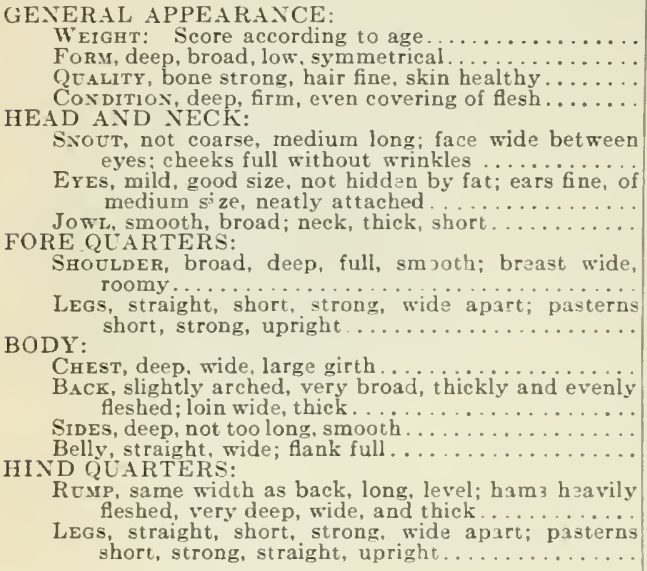 & $\begin{array}{r}2 \\
2 \\
3 \\
5 \\
5 \\
4 \\
3 \\
15 \\
6 \\
6\end{array}$ & & \\
\hline Total score....................... & $10)$ & & \\
\hline
\end{tabular}

The general form of the hog may be studied from different points of view. A short cane or stick is useful to change the position of an animal in order to observe it to the best advantage. Hogs tend to keep the head close to the ground, and rarely stand with the four legs in good position beneath the body. For these reasons it is well to keep animals of this class more or less in motion while judging. Width of back and depth of rib should be noted from over-head or from one side, while a fullness of both front and hind parts should be easily seen from front and rear. In this inspection compactness of form, and quality, should be manifest. One may easily determine the quality by eye examination, but a feel of the hair will reveal marked differences in quality, that along the neek and front part of the spine being always the 
coarsest. While condition may be easily seen and estimated by the eye, if one will press with the ends of the fingers along on the back and sides, a better idea will be had of the depth and evenness of covering, and condition of skin. In the case of aged boars, there will be noted a very thick, coarse development of skin over the shoulders, known as the "shields." This is an inheritance from the wild ancestors, and really serves as a shield; for, when fighting, pigs strike with their heads against the shoulders of the opponent. The tusks of the boar cannot easily tear through this shield. Yet this thick, heavy covering of hide is very objectionable, and the best show animals do not have it. Symmetry of form is important; and if the front part of the body is thick and heavy, and the hind part narrow, the form certainly will not be well balanced.

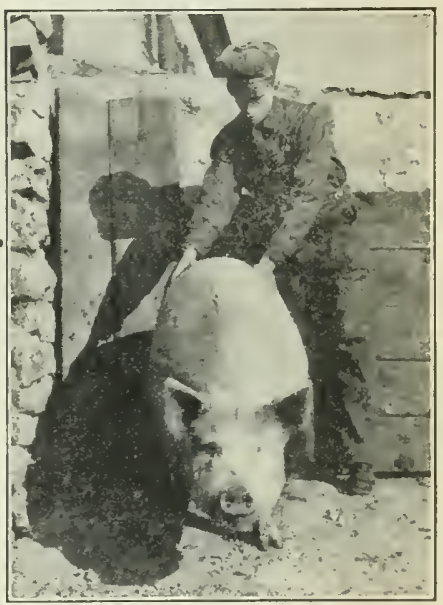

Fig. 132. A study of the width of back. Photograph by the author.

The head of the hog varies so in size and form, according to breed, that it seems best to emphasize only certain features that should be common to all breeds and grades. The large, coarse head is an evidence of waste, hence buyers prefer a short type of head, indicating smaller loss in this portion in killing. Even with the long headed breeds, refinement is considered important, as indicated by length and coarseness of snout. The eyes should always be easily seen, and preferably the whites of the eyes to some extent. The eyes of 
the hog of the lard type tend to become surrounded by excessive fat, so that the sight is very poor. The ears are good indicators of quality. They should be easily earried,

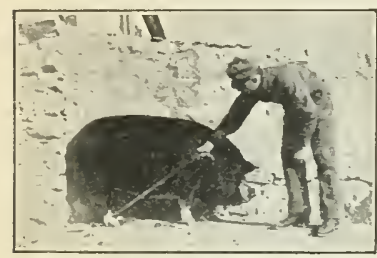

Fig. 133. Pointing at the pasterns. Photograph by the author.

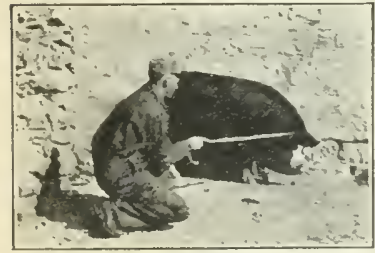

Fig. 134. Pointing at the neck. Photograph by the author.

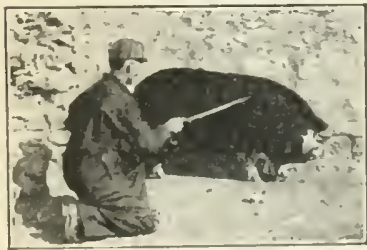

Fig. 135. l'ointing at the shoulder. Photograph by the author. and not be heavy and eoarse where attached to the head. None of the lard-type breeds naturally have coarse ears.

The neck of the hog should be reasonably short and broad on top, and blend smoothly into the shoulders. A common fault is a thin neck, fitting roughly in the shoulders which stand out in a prominent manner at the shoulder vein.

The jowl of the hog is the thiek, fleshy part of the lower jaw and throat. Sometimes it is very large and round, and is a great mass of fat. Often decp, hairy creases oceur here. The jowl cannot be studied to advantage unless it is both seen and felt. If the animal keeps its head elose to the ground, the jowl eamnot be thoroughly examined. The best form is short, smooth, free of creases, and reasonably firm to the touch.

The shoulders of the hog vary considerably. The tendeney is for them to be heary or eoarse, and open on top, the blacles not lying back in close. The shoulder's are valuable for meat, and the more they are covered with 
flesh the better they are. If wide on top, the chest below will no doubt appear narrow. By examining from over-head, and then from in front, kneeling somewhat, the relationship of width of chest to position of shoulders may be seen. While the breast of the hog does not appear as prominent as with other animals, on account of the low carriage of the head, if the shoulders are placed right, the breast will be wide and full and the front legs will come down in good form. By means of the hand one can feel the end of the breast bone, which should extend at least beyond the legs. Such a breast development shows good constitution.

The back of the hog is one of the most valuable parts, for here the butcher secures chops, roasts, and lard. The wider and better condition of back and loin, the more high-class cuts the butcher will be able to obtain from the carcass. In the older and larger fat hogs, the layer of fat over the back is very thick, ranging from two to three inches. Such animals are frequently referred to in the market

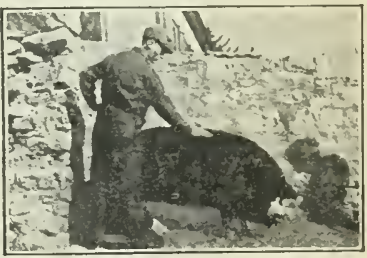

Fig. 136. Feeling for back covering. Photograph by the author. as "fat backs," and long strips of the fat are cut from this part and rendered into lard. A wide back is an indication not only of the condition of flesh, but also of the capacity below for the vital organs and the digestive system. Generally, a long rib and large chest capacity go with width on top. In inspecting the back, as viewed from one side, emphasize a strong carriage, with a slight arching. Young pigs frequently have a depression behind the shoulders, which fills up on fattening. A full, strong development here is desirable.

The sides of the hog should be fairly deep and smooth, 
and uniformly so from the front to hind flank. This part furnishes the bacon cuts, hence a smooth, uniform condition of flesh is important. Creases very commonly occur along the upper part of the sides and give a bad appearance to the body. Often one may easily insert the fingers in these

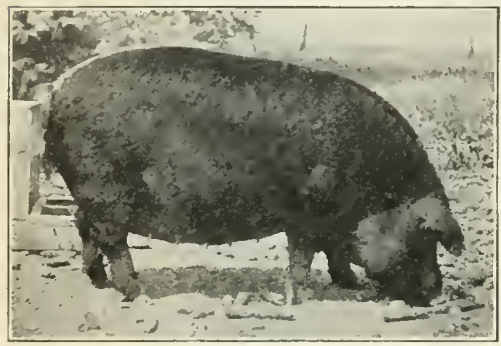

Fig. 137. Quality as shown in the smooth side of the pig. Photograph by courtesy of The Farmer. creases. The lard type does not have a long side, as a rule; neither is it quite flat, as viewed from one side. The form tends to be somewhat oval, especially with hogs with $\mathrm{Po}-$ land-China, Duroc-Jersey, or Chester White blood, consequently the upper part of the side projects some beyond the' lower portion. Emphasize also smoothness of fleshing, and quality of skin.

The belly of the hog should suggest as little waste as possible. A paunchy condition, that is, a round, sleek form, indicates excess offal. A clean, straight line, as viewed from one side, with full flanks, is what is wanted. Where an excess of belly occurs, as in the case of old sows, buyers throw off a certain amount of weight, or as they say in the market, "dock" the animals.

The hind quarters of the hog are very important, becauso they include the hams. The hams represent a high-priced and heavy-weighing part, so that a thick, full development is here sought. Standing behind the hog, one should note that the width is earried full, from the hips back to the end of the body. The thighs should be wide spread on the outside, and very thickly muscled between, with the twist extending low 
down toward the hocks. The tail attachment should not be set low. Great depth of hams from behind is most desirable.

From one side, the rump should be long on top, level rather than steep, and long also from hip to hock. A very steep rump is often seen, with the legs carried under the body, thus furnishing a weak support. The steep rump does not allow a good position of legs. Side or rear view should show a very meaty ham, somewhat bulging in its lower part. Smoothness of covering of ham is important, as wrinkles and uneven eondition injure the value in the meat trade.

The legs of the hog, as viewred in front, at one side, and from behind, should be short and straight, and not coarse of bone. The front legs sometimes nearly touch at the knees, giving what is termed a buck-kneed effeet. This usually accompanies the narrow chest. The hind legs frequently are close together at the hocks with the feet widely spread below the body. Such a position usually goes with a narrow thigh, or ham. Pasterns and feet have already been discussed in this chapter, and need not be referred to again, except to emphasize the correct position of these parts as most important in supporting a heavy body weight.

In judging breeding stock of the lard type, the same general features are to be considered, making exceptions for sex character and a leaner condition. The mature male requires a head showing great vigor and masculinity, with a strong jaw, prominent tusks, breadth of forehead, a strong neck, and some thickness of shoulder. Most breeders also prefer breeding stock which have very good length, and are not too short and compact. More bone is looked for in the boar than in the sow or fat hog. In fact, breeders rarcly criticise a boar for having too heavy bone. The brood sow should show good size and length, yet have a strong, well-supported back. Deptlı and length are most valued qualities in her 
case, as these indicate large reproductive capacity. Sows frequently are too light in bone for their weight, and this defect should be noted. The sow should be quiet, yet active, but not nervous and exeitable. An irritable sow is almost sure to make a bad mother.

\section{THE BACON TYPE OF HOG}

The bacon type of hog is produced in comparatively small numbers in the United States; but owing to the increased demand for bacon, no doubt more hogs of this sort will be bred in the future.

A score card for the bacon hog gives a very good idea of the special features emphasized in this type.

Score Card for Bacon Hogs.

GENERAL APPEARANCE:

WEIGHT, market hogs should weigh 160-220 lbs

Fors, long, smooth, level back, belly neat....

QUALITY, hair fine; skin smooth and free of wrinkles; bone strong but not coarsa; flesh firm.

Coxprtios, well covered with firm flesh, especially on

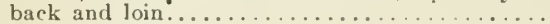
HEAD AND NECli:

SNout, medium long; face, broad at eyes

Eres, good size, bright; ears, medium size, not coarse

Jowl, not very wide, muscular, smooth; neck, medium long, m

FORE QUARTIER:

SHOULDERS, smooth, well laid in; breast, full . . . . . . .
LEGS. medium long, straight, well placed, not coars BODY: pasterns ereet and straight...

BAck, medium width, slight arch neck to tail; loin same width, strong, full

RIBs, well sprung, long; side, long, smooth, inedium deep.

Cinest, full, even with shoulder; flanks full and low

BELLY, firm, triın, thick, not flablyy or shrunkin

HJNI) QUARTERS:

R TMP, same width as back, long, level. . . . . . . .

Hass, full, not flabby; thigh tapering towarl hoik. without folds or wrinkles.

LEGS, medium long, locks well set apart, straight, bone good, pasterns erect. ..............

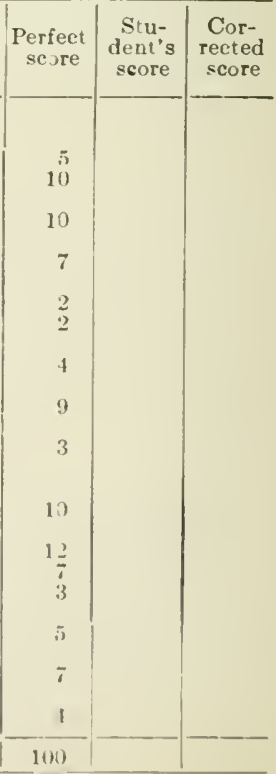


Judging the bacon hog requires keeping in mind certain important features wherein this type differs from the lard hog. Bacon is the first consideration. This comes from the sides; therefore the side that is longest and smoothest, with fair depth, is the most valuable. But bacon must not be heavy in fat, hence the condition of the body must show only a moderate amount of flesh. For these reasons, the bacon hog shows a comparatively narrow back, but considerable length of body. Over the back of the bacon hog, a uniform depth of about one inch of fat is ample, for a muscular carcass with a reasonable amount of fat is what is desired.

The shoulder of the bacon hog should be smooth, and not heavy like the lard type, but should nicely blend into the body. The thickness between the shoulders is not great, and a front view shows a relatively narrower neck

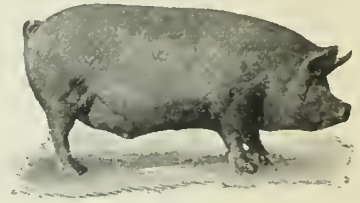

Fig. 13s. A baenn barrow. Photograph by the author. and chest and longer leg, compared with the lard type.

The ham of the bacon hog lacks in thickness, yet should be long on top, and taper off into a lean type, with no great amount of fat. From a side view, the ham cuts away more on its under part; while from behind, the thighs are thin and are well split up between, with rather a shallow twist.

The belly of the bacon hog should show just as little fullness as possible, consistent with being a good feeder. Any evidence of paunchiness or thickness here is objectionable. The lower part of the body line should be smooth and trim, and give evidence of the least amount of offal.

The general appearance of the bacon type is that of a narrow, long-bodied, smooth-sided, long-legged hog, not too fat in any portion. The excessive length of leg, which often prevails, is to be criticised; otherwise these 
features of conformation are very desirable and should be maintained.

\section{AMONG OTHER THINGS, THINK ABOUT}

1. Quality as an important feature of the hog.

2. The occurrence of seams, or creases, and why objectionable.

3. The pasterns, past and present.

4. The five features most highly rated in the scale of points.

5. The "shield" and its significance.

6. Thie relation of breast to shonlder and constitution.

7. Where the most important "cuts" are found in the carcass.

8. Differences between breeding stock and that for the butcher:

9. The meaning of bacon type.

10. Relation of bacon form to offal.

SOME NEIGHBORHOOD INVESTIGATIONS

11. Place on a township map the locations of market feeders of hogs.

12. Do feeders breed or purchase the stock fed?

13. What attention is given to quality by mon buying hogs?

14. Does the lard or the bacon type prevail in your locality?

15. Bring to class a score-card record of some animal in the home herd.

16. Organize a local swine-judging contest. 


\section{CHAPTER XIII}

\section{HEREDITY: ITS MEANING AND INFLUENCE}

The word heredity has long been used by scientific men when discussing the important subject of breeding animals and plants. As commonly defined, it means the reproduction in the offspring of the characteristics of the parents. However, it means more than that, because the parentage of an animal or plant extends farther back than one generation.

The degree or extent that characteristics may be inherited from parents, grandparents, and more distant generations, cannot be absolutely determined. Yet, that animals and plants do inherit from other generations than the parents, is a matter of common knowledge. In fact, everything found in the animal, whether physical or mental, excepting certain diseases, has been transmitted through previous generations. We know that under average conditions there is a certain degree of resemblance between an animal and its various ancestors. Yet there are conditions which greatly affect heredity. Writing on "the complex nature of heredity," Davenport says:* "The most disconcerting principle in all improvement operations lies back of the obvious fact that the offspring is not like the parent. Having two parents, he could not of course be like them both. The fact is, however, that for the must part he is not like either one of them, nor yet is he like the two combined. The most that can be said is that the offspring resembles his parents, and that all his characters are to be found somewhere in his parentage."

The persistence of heredity is a most important factor in its influence on the offspring. The older and better

*Domesticated Animals and Plants, 1910, p. 154. 
established the family, the more uniform and certain is the transmission. We say that an animal, family, breed, or race that transmits its special characteristics with much certainty, is prepotent. This word suggests power, and really means superior influence. Wild animals and birds represent the purest and most prepotent breeding. They live and develop under conditions that are most natural and uniform, thus resulting in the least change. One wild fox differs but little from other wild foxes of the same kind, in form, color, and mental traits. In the opinion of most men they must have had these characters for a great length of time. The same thing applies to any other one species, the product of wild conditions.

The most prepotent domestic animals are those that have been bred pure for long generations. A breed like Short-

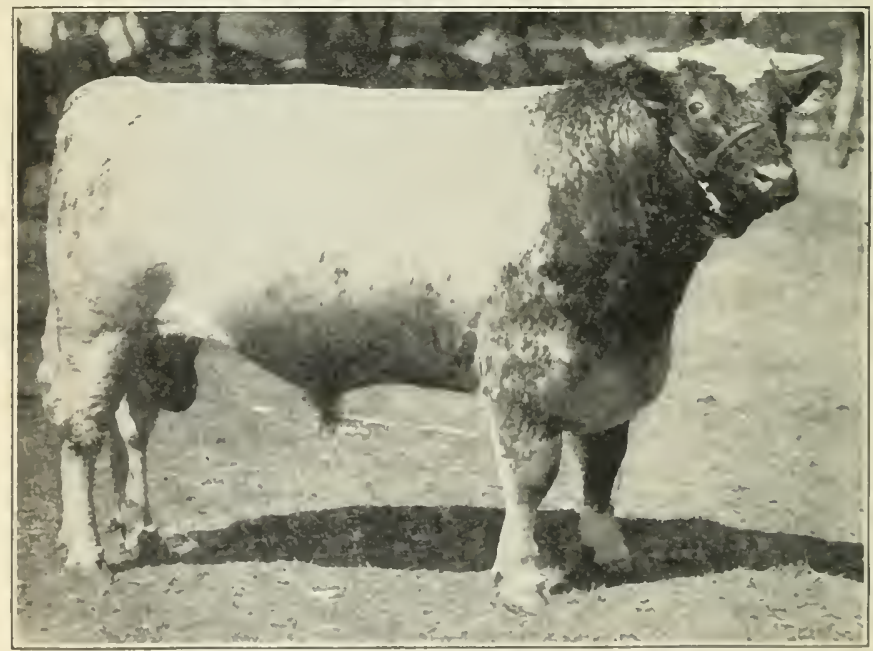

Fig. 139. A fine type of a breeding bull, showing masulinity and character. Photograph by courtesy The Farmer. 
horn cattle, the pedigrees of which can be traced back for a hundred years, represents a comparatively well-established type and character. In a herd of these eattle we should expect to find the typical horn and head, the general body form, and the red, white, or roan color so universally known. We have examples, however, of old breeds that have not

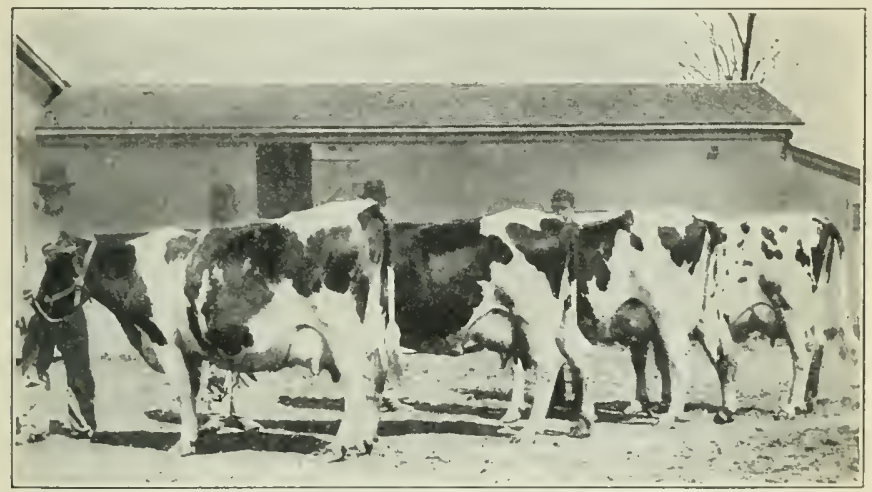

Fig. 140. The Holstein-Friesian cow Prilly 40082 at 13 years old, on the left, and her three daughters, Beauty Pietertje, Cleopatra Gelsches, and Eliza Pietertje, all great producers. Photograph by courtesy of H. A. Moyer, owner of the cows.

been developed by master breeders, and consequently a lack of individual excellence among a great number of the animals is found.

The importance of heredity in stock breeding has long been recognized. The men who have been most noted in the development of each of the great breeds have agreed that the saying, "like produces like," contains much truth. In fact, in breeding operations they have placed a premium on prepoteney and uniformity of character. Bates, the great Shorthorn breeder, was a stickler for type and character. The same may be said of any other man who has been really 
successful as a breeder. If a man wishes to produce race horses, he inust use race-horse blood, in which speed has been the important feature. Great records are being made among dairy cattle today, and certain families are noted producers. In studying the history of the development of the modern dairy cow, one will find that the inheritance of producing capacity is a great prepotent feature. Anyone who attempts to establish and develop a herd without being guided by such information will certainly fail in his purpose.

The importance of an ideal in breeding cannot be overestimated. Men who have done much to assist in developing breeds, and have become famous in this work, are commonly called "master breeders." In the upbuilding of the Shorthorn, the Colling Brothers, Bates, the Booths, and Cruickshank were all known as great constructive breeders. These men had their ideals or standards, and bred up to them as closely as possible. Two men start out with herds of cattle of equal merit. One man has ideals of what he should do. He carefully studies his eattle and the laws of heredity, and seeks constantly to improve his herd. At the end of 25 years he has a fine herd, that is a marked improvement over his foundation stock, and from which he derives much praise-worthy fame and substantial profit. The other man has no ideals or policy. He is satisfied with things as he receires them, he does not study his business, and as might have been expectetl, his stock becomes inferior and unprofitable, he gets in debt, and ends possibly in bankruptey. One man is a benefit to his community, the other is not, yet each had an equal chance at the start.

Certain useful and valuable forms of inheritance exist among the improved types and breeds of farm animals, and the perpetuation of these qualities is most important, if one is to make a success of breeding. Some of these forms that 
directly concern the stockman are the following: (a) Color markings. One of the most important features of breed identification is the color. Some breeds possess a solid, uniform color, as the red of the Red Polled cattle, the black of the Aberdeen Angus, the white of the Chester White and Large Yorkshire pigs, and the red of the Duroc-Jersey. Each breed has its standard color or colors, and anything varying from this, as a rule, causes disqualification. Milk production. The Holstein-Friesian breed is noted for

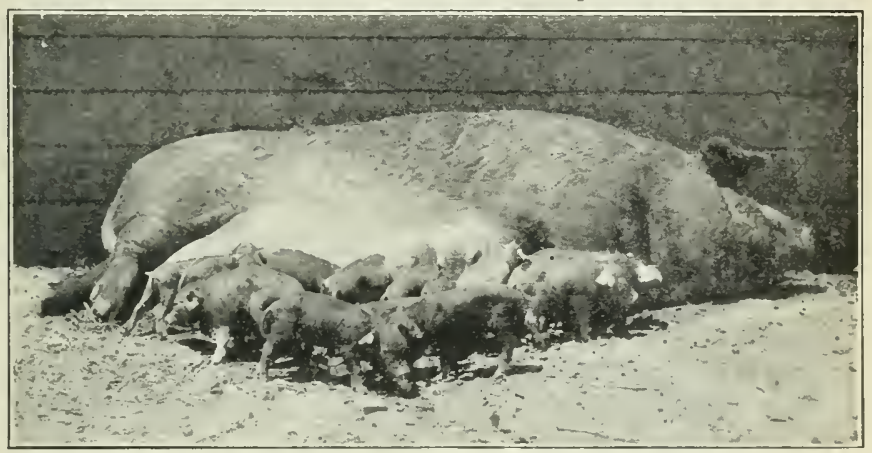

Fig. 141. A good example of fecundity. A Duroc-Jersey sow and litter of 14 pigs. Photograph by courtesy Ohio Agr. Exp. Station.

the large milk flow of the cows. No other breed of cows equal these in heary flow of milk, and no feature does more to make the Holstein-Friesian famous than that of milk production. (c) Fecundity is especially a hereditary character. Shropshire sheep have been noted for many years for the large percentage of twins dropped by the ewes. The Large Yorkshire and the Tamworth breeds of hogs are famous for the large litters farrowed by the sows, while of the lardtype breeds, the Duroc-Jersey is prominent in this respect. (d) Temperament. As a rule, animals of a heavy, fleshy' 
type are more phlegmatie and less nervous than those of more muscular build. Draft horses, beef eattle, mutton sheep, and lard hogs all show to a certain extent this relationship of form to temperament. (e) Speed is a striking feature of the horse of light and muscular eonformation. A study of the pedigrees of running horses prominent today will in many cases show lines of deseent from the Darley Arabian, with long lists of celebrated racers in between, covering the period of over a century. In the same way, the record of inherited speed of the American trotter may be traced in a most interesting way, from the present back some 75 years to old imported Bellfounder, the sire of the dam of Hambletonian 10, the most noted speed sire in the history of America.

Peculiar or interesting characters are also transmitted from one generation to another. We are usually most impressed with the eommonest things in animal inheritance, yet there are remarkable charaeteristies that are well worth attention, and such as demand consideration from the thoughtful stoekman. Usually these are valued as breed features, yet in themselves they have no useful attributes. Some examples of these are the following: The solid hoof in the hog is a rare oceurrence, except with one breed, the Mule Foot. This characteristie is of no speeial value, but it has been made the subjeet of much publicity, and many persons from curiosity have purchased specimens of Mule Foot hogs. A pug-nosed, dished face is a distinct feature of the Small Yorkshire breed of swine. Often these pigs are bred so that the lower jaw projects with an upward curve beyond the short, dished upper jaw, scriously affecting ease of eating. Berkshire breeders in Ameriea in late years have also had a tendency to breed these very short, turned-up faces. Such heads are monstrosities, in the same class with those of bull dogs and Boston terriers. Five toes on cach foot are found 
on the Houdan breed of chickens. This number of toes commonly occurs on all good specimens of this variety of French fowls, although four is the usual number with most other breeds.

Latent hereditary characters exist in all animal life. By this is meant characteristics that are not visible in any form in one or more generations, yet have occurred in the past, and may again appear at some time in future. During the past, students of heredity have called such occurrences "atavism," while stockmen have been in the habit of referring to them as "throwing back," or "breeding back." For example, we have a case of a family of Aberdeen Angus cattle, which is a black breed. Very unexpectedly a red colf is dropped in a herd where not a red animal has been known. Yet a careful study of the history of this herd will show that at a previous period there was a red ancestor. This red color was really hereditary, but lay dormant, or latent, as it is termed, for some generations, and then cropped out. The stockman now calls this a "sport." Some scientists speak of it as "mutation." The important point, however, is that this character really was inherited from generation to generation, but did not appear until certain conditions were favorable. Many similar eases might be cited that have caused much comment among stockmen. In this connection, it may be noted that mutation occurs less frequently with old, well-established breeds than with those not so old, and less under natural than under artificial conditions. It is also important to remember that sometimes mutation results in valuable variations from the parent type. Instances have occurred where intelligent breeders have recognized the value of such a "sport," and have succeeded in reproducing it through successive generations, until it became a fixed breed feature. More than one homless breed of cattle and sheep have been 
founded by a polled animal unexpectedly appearing in a horned herd. This applies especially to Polled Jersey, Polled Hereford, and Polled Durham eattle.

Variation in animal character is to be seen on every hand. No two animals are exactly alike. In a family of the same parentage we find striking differences. Within our intimate

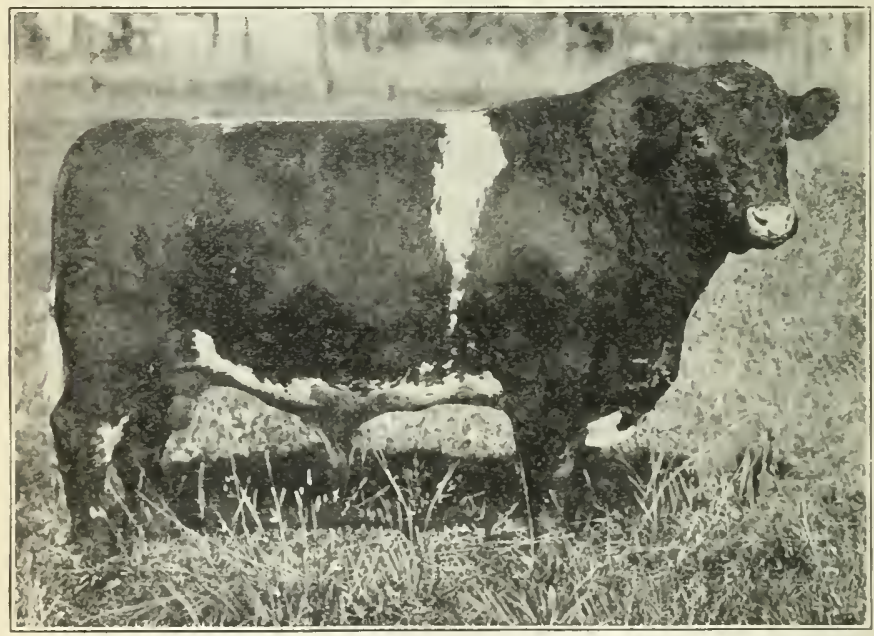

Fig. 142. Pollerl Durham bull, The Confessor 284217. owned by J. H. Miller \& Fons, of Indiana. Photograph from the owners.

acquaintanee, we are often impressed with the striking differences between members of the same family. Among our domestic animals differences also exist in no small degree, although our attention may not be attracted by them in the same manner as in the human family. Yet variation is a common oceurrenee in all life. It is due to this very fact that man has been ahle to improve and develop our farm amimals to their present stage of perfection. Animal life 
is plastic and more or less susceptible to the influence of artificial conditions which man more or less controls. Food, habits, surroundings, the care of man, all of these affect the development of the dumb beast in a notable manner. It should be the business of the stockman to study these conditions and make use of them to the material improvement of his own herd.

\section{IF YOU INHERIT A GOOD MEMORY, YOU SHOULD KNOW}

1. The meaning of the word heredity.

2. Under what conditions prepotency is best seen.

3. Why a knowledge of heredity is important in stock breeding.

4. What is meant by master breeders.

5. The value of color markings in breed inheritance.

6 . The relation of conformation and inherited speed.

7. Some peculiar forms of heredity.

8. The possible value of mutation.

9. What conditions influence variation.

\section{FIND EXAMPLES OF INTERESTING CASES OF HEREDITY}

10. Report on the best examples of heredity extending over at least two generations, in which very similar characters appear. why?

11. What is the most prepotent animal in the neighborhood, and

12. Report on any herd showing high ideals of the owner.

13. Interesting cases of fecundity among brood sows are not difficult to find. Look some up and report upon them.

14. What is the most interesting and peculiar case of heredity within your knowledge?

15. Find a case of atavism worth reporting. 


\section{CHAPTER XIV}

\section{SELECTION AND ITS IMPORTANCE}

The principle of selection involves some method by which one or more animals are selected for specific purposes. The scientist recognizes two great classes of selection, one, natural; the other, artificial.

Natural selection is the process in operation among wild animals by which individuals choose or select their mates. Force is an important medium under such eireumstances. A good example of the application of natural selection is found with the deer. The males fight among themselves to determine which shall be master of the herd, and the strongest, most masterful secures the leadership. This is what is sometimes termed "the survival of the fittest." Among all wild animals a similar method of selection exists to a more or less degree. This system weeds out the weakly, inferior animals and promotes the vitality of the race. Referring to this subject, Henry Drummond states:* "The object of the survival of the fittest is to produce fitness, and it does so, both negatively and positively. In the first place it produces fitness by killing off the unfit. Without the rigorous weeding ont of the imperfeet the progress of the world had not been possible. If fit and unfit indiseriminately had been allowed to live and reproduee their kind, every improvement which any individual might aequire would be degraded to the common level in the course of a few generations. Progress ean only start by one or two individuals shooting ahead of their species, and their life gain can only

*The Ascent of Man. 
be conserved by their being shut off from their species, or by their species being shut off from them." Again he says: "If a given number must die, that number must be singled out upon some principle, and we cannot quarrel with the principle in physical nature which condemns to death the worst." Natural selection therefore represents a progressive development, with each succeeding generation somewhat stronger and better bred for meeting the requirements of existence. An especially interesting phase of natural selection is, that through it the species is developed so as to be best adapted to its purpose and condition of living.

Artificial selection involves the introduction of man. He controls the matter of selection, and thereby is able to cause the animal to vary more or less from the parent type. In the earliest times, no doubt man exercised some control over the animals that he found useful, and caused changes in their development. Thus man's ability to affect the purpose and value of dumb animals must have appeared evident to him long ago. The famous sculptures of Egypt and Nineveh, dating back thousands of years, show that domestic animals at that time must have been improved by man through the practice of selection. The Bible has been repeatedly quoted by writers on heredity, to show that the influence of selection was recognized prior to the time of Christ, as expressed in Genesis. Early writers like Plato, Pliny, and Columella, all refer to the improvement of live stock by selection. All through the intervening centuries up to the present time, interesting references occur in history of animal improvement being sought through selection.

Methodical selection is a term used by Darwin to express the more systematic artificial process. In his most interesting work on "Animals and Plants Under Domestication," he presents much evidence to show the practical application 
of selection, and especially how by a methodical, carefullyplanned system, remarkable results have been secured. Referring to this method, Darwin says: "Few persons, except breeders, are aware of the systematic care taken in selecting animals, and of the necessity of haring a clear and almost prophetic vision into futurity. Lord Spencer's skill and judgment were well known; and he writes: 'It is therefore very desirable, before any man commences to breed either cattle or sheep, that he should make up hismind to the shape and qualities he wishes to obtain, and steadily pursue this object.' Lord Somerville, in speaking of the marvelous

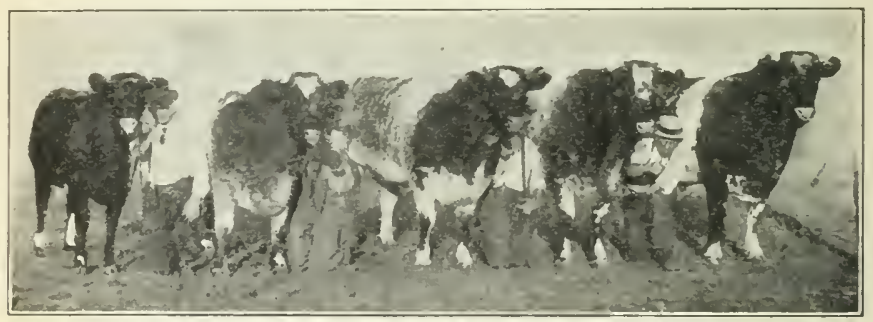

Fig. 143. The first prize herd of Shorthorns, Ringmaster at head, the result of a policy in selection. Photograph by courtesy The Farmer.

improvement of the New Leicester sheep, effected by Bakewell and his suecessors, says: 'It would seem as if they had drawn a perfect form, and then given it life.'

In connection with the practice of selection, it is important that the breeder keep in view eertain necessary things, if he is to be successful in accomplishing his purpose.

A policy in selection is essential. Whether one is to breed one kind of live stoek or another, he should not only have carefully considered plans, but shoukd hold to them. One of the great reasons for non-success on the part of many breeders is the lack of a definite, well-founded policy. A man starts 
to breeding beef cattle, and after a time concludes he prefers a dairy breed; so he disposes of his beef stock. Thus years of effort may be upset in a few days. More than one man in a vainglorious way has stated that he has tried all the breeds of this or that kind of stock, and that he knows all about them. Such a statement is ample evidence of superficial knowledge and policy.

Intelligent selection requires severe culling of the herd. Men improve the average of the herd through the removal of the more undesirable animals. Some persons, however, find it difficult to do this, on the plea that they cannot afford it, or that the misfits will do for the present. Yet the more uniform the excellence of the animals in a group, the more profitable the results to be secured. George A. Brown refers* to a practice followed in many parts of Australia, of employing an expert to cull and select the breeders in Merino stud flocks. Comment is made that, when the expert really understands his business, this plan has its advantages. A young stockman, by closely watching the methods of the expert, will gain a better insight into the business of selection for stud breeding than he could by any other means.

Selection as a means of securing desirable characters is one of the most easily applied practices. It is common to find certain recognized weaknesses or defects within a herd. It may be shown, for example, in a heavy, plain shoulder, or a weak, narrow back or an inferior hind quarter. The necessary thing to do under such circumstances is first, to secure a sire that is especially strong where the females are weak; and secondly, to dispose as rapidly as possible of the animals that possess these deficiencies in the most striking degree. In the most progressive live-stóck communities,

*S.udier in Stock Breeding, 1902, page 354. 
high-class breeding stock is greatly valued. In fact, we have no way of accurately measuring the value of a great, prepotent sire. It is understood by those familiar with many British flocks and herds that the best breeding animals cannot be purchased; they are not for sale. It is an old story that Edwin Hammond refused an enormous sum for the famous Merino ram Gold Drop, his reason being that he could not afford to sell his best ram at any price. Brown states that on one

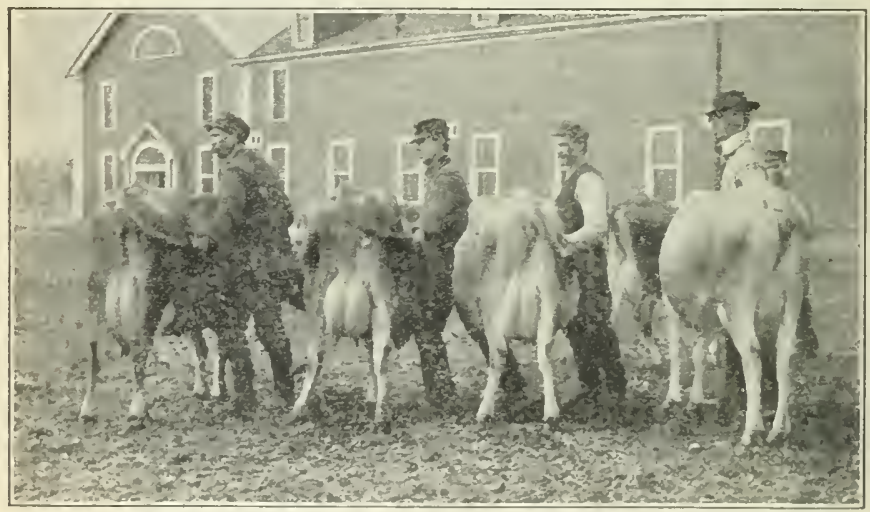

Fig. 144. These eows were the result of selection for butter-fat production. Photograph by the author.

occasion a wealthy Tasmanian sheep breeder offered one of the most skillful island stud owners $\$ 500$ each for the pick of a score of ewes from his stud, and the offer was refused. These animals transmitted most valuable qualities to future generations, in no unecrtain manner, the perpetuation of which qualities was of vital importance to the owner. At the present time great interest is shown in dairy eattle, and the marked improvement in produeing capacity in many herds is evident through the use of sires that come from dams and 
families notable for milk or butter-fat records. Suppose a man desires to purchase a bull. Would it not be a fine investment to secure one from ancestry that would result in a herd of cows that would yield 400 pounds of butter-fat, each, per year, as compared with a sire producing cows giving only 200 pounds of butter-fat? Think of the difference in the final gain to the man and to the breed! One thing should be kept in mind in the effort to secure and hold desirable qualities, and that is not to breed with a narrow, one-sided policy, remembering that the greatest general perfection of form and function should always be the final object of the breeder.

Selection and environment have much in common. By environment is meant the conditions of climate, soil, shelter, etc. In very recent years the word "genetics" has come into use, and will no doubt become more common in the future. It refers to breeding scientifically, depending upon hereditary transmission, without regard to environment. When starting in the business of breeding, it is very generally considered important that animals be selected that are suited to the special eonditions under which they must live. While it is true that domestic animals are adaptable, the different breeds are not equally so. Some, as for example, the Shorthorn, seem to thrive under a wide range of conditions. Others are much less suited to change. Large, heavy animals are better adapted to the lower lying lands and richer pastures; while the lighter, smaller type thrives in the hill country, where herbage is not so abundant. There are cases where men have persistently held to a breed under adverse conditions, and have selected until an adjustment was reached between the animal and the climate and the breeder. Brown states that one of the greatest triumphs achieved by the husbandman, with the aid of selection, has been in stocking the "great thirst land of central Australia" with Merino sheep. 
When first taken to that country, they deteriorated greatly. The wool was reduced to less than half the original length, and became dry, very brittle, and open. Many sheep farmers gave up the attempt to produce the Merino as hopeless, but others persevered, and finally succeeded in producing sheep with fine frames and splendid fleeces. If one will carefully study breed distribution in America, he will find that in some localities certain breeds are selected in preference to all others. For illustration, in the southern states Jersey cattle and Berkshire hogs are kept in preference to all other breeds. In warm climates a dark-skinmed animal suffers from the heat less, and consequently hogs and cattle with dark skins prevail. Wisdom would justify no other policy of selection. Feeding is also an important factor in hereditary transmission. It is amply demonstrated that animals transferred from conditions of food scarcity to an environment of abundance, through successive generations take on an increase in size. The Shetland pony on its native isles, subject to cold and more or less starvation, is a smaller, more inferior animal than that of the same ancestry, but which has passed through several generations in the prairie country of America, where food is most abundant. Men may buy fine animals for their herds, but unless properly fed and cared for, depreciation is sure to follow from generation to generation.

Uniformity in type of foundation stock should be most carefully considered. It is a common method for young men starting herds, to buy females without regard to uniformity of type. The result is that herds thus begun do not attain the standing they should, because of variation in the offspring, due to the lack of methodical selection at the start. One might far better begin with three females of uniform type and excellence, than with a much larger number of no uni- 
formity. The final outcome with the three would certainly encourage observers to pursue a similar method.

A knowledge of breed character is requisite if one is to beeome an intelligent breeder. All of our farm animals may be grouped into breeds, crosses, grades, or serubs. Any improvement made must come through the breed, or pure-bred line. Our breeds are the outcome of systematic selection and improvement. Present-clay standards are undoubtedly higher than ever, and breeders demand more and more merit in breed representatives. This being so, it is highly important that the stockman should be quite familiar with the seale of points, moulding all the desirable qualities into an ideal worthy of the breed, and then endeavor to

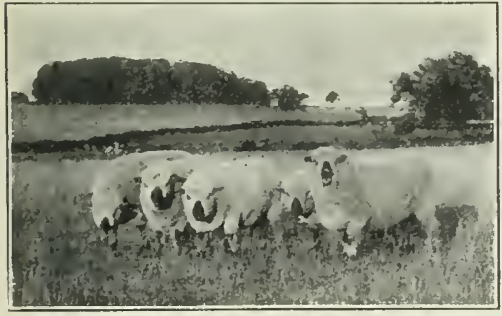

Fig. 145. Shropshire sheep heavily cover ed with wool over the head. Photograph by the author. produce animals that come nearest to that ideal. Such knowledge also calls for a keen discrimination in selecting the breeding stock by which the herd is maintained.

Rational selection is a thing greatly to be desired on the part of breeders. Too many persons are influenced in their selection by passing fads. In the past, men have insisted on maintaining herds of red Shorthorns, or solid-colored Jerseys, allowing these fancy points to obscure more important ones. Hogs have been bred with such extreme dish of head as to make it impossible for them to eat in a natural way. Sheep have been bred with such heavy coverings of wool over the face as to prevent the use of the eyes. These features should never obscure the vision of the breeder. 
Rational selection requires putting a premium on constitutional vigor, size, and quality, and then wisely giving fancy characteristics of color, head, or covering of wool secondary consideration. It is not meant that these features should be ignored. In fact, they serve in part as factors in breed identity, but so also do other things. Nothing is so essential as vigorous constitution, and rational selection would naturally place a premium on this. One may strike the happy medium on fancy points without detriment to his herd, and at the same time preserve the desirable qualities, thereby attracting buyers. But what could be more unwise than to neglect constitution in order to maintain some special color character? Yet more than one breeder has been guilty of this.

The selection of the pedigree. One camnot practice selection and ignore pedigree. Persons familiar with lines of family breeding recognize that more merit exists in some than in others. The men who have been most suecessful as breeders have always refrained from purchasing animals the pedigrees of which showed undesirable ancestry. Auetion sales of live stock bring out various interesting features, chief among which is the relatively higher price paid for animals of recognized satisfactory pedigree. While it is true that in the past many animals have sold at high prices, largely on the basis of pedigree and without merit otherwise, the fact remains that as a general rule, a combination of individual excellence and meritorious pedigree brings the highest price. The man who combines the eapable judge and wise interpreter of pedigree is qualified to select to the best advantage. 


\section{A SAMPLE SELECTION OF QUESTIONS ON SELECTION}

1. What is natural selection?

2. What did Darwin say about methodical selection?

3. What is the Australian method of eulling and seleeting sheep?

4. How have great sires been valued by their owners?

5. What is the relation of animal development to soil and climate?

6. Why aim for uniformity of type in founding a herd?

7. What is rational seleetion? Illustrate.

8. How important is eonstitution?

9. What part should pedigree play in buying breeding animals?

\section{SUGGESTIONS FOR INVESTIGATIONS IN SELECTION}

10. Make a report on Charles Darwin as a student of seleetion.

11. What breeders that you know practice methodieal selection?

12. Are there any sires in your eounty highly valued by their owners? If so, what are they, their value, and why so valued?

13. Give local examples of dairy eows having official records of milk or butter-fat produetion. Are these the result of careful selection? 


\section{CHAPTER XV}

\section{PEDIGREES AND THEIR VALUE}

The pedigree of an animal shows the consecutive relationship of an animal to its ancestors. Of some animals we say that they are pure-breds, while others are known as scrubs or mongrels. The pure-bred has a known pedigree, while the scrub has not. Men have developed herds of animals of similar character and ancestry from which they uniformly reproduce the parent type, and have kept careful records of the breeding. Such animals form a breed. To be pure bred, an animal must show in its pedigree that it traces back wholly within the blood lines from which the stock originated. If an animal is not pure bred, it may combine in its pedigree widely differing blood lines that are more or less out of harmony with one another.

A cross-bred animal has a pedigree that on the sire's side is of one breed, and of another on the dam's side. As a rule, cross breeding is very undesirable, and should be carried only one generation, and then for the production of fceding-stock only.

A grade animal, in the large majority of cases, has a purebred sire, but is out of a dam that is not pure-bred. One often hears the expression high grade, which means that the animal referred to is by a purc-bred sire, and out of a dam that contains much pure blood stock. A high grade herd of Herefords would consist of a collection of animals that started with just common or scrub breeding stock, but in which for some gencrations none but pure-bred males were used as sires. Thus a systematie improvement of the herd 
would be made. The degree of improvement may be expressed as follows:

1st generation $=$ Pure sire, scrub dam. The offspring $=1 / 2$ blood

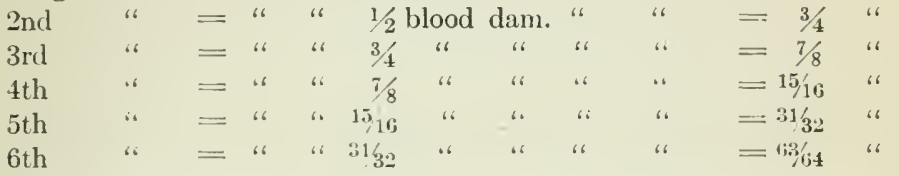

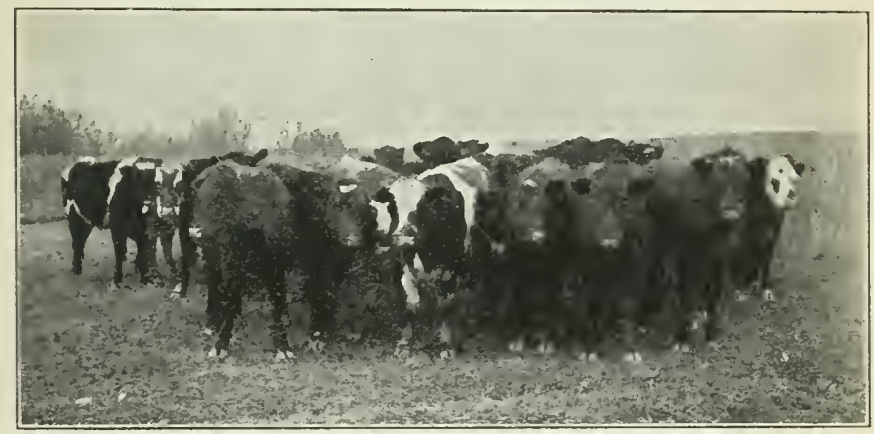

Fig. 146. A herd of grade feeder cattle at the Ohio Experiment Station. Photograph by courtesy of the Ohio Agricultural Experiment Station.

Thus it can be seen that in time a herd may become practically pure-bred, although one will not be able to register this high grade stock in most breed registry associations. Yet all pedigrees really start from grade ancestry.

The bracket form of constructing a pedigree shows the family relationship by means of a series of brackets, after the following manner. This is the most common form in use.

DUROC-JERSEy BoAR,
Orion Chief 13333 $\begin{cases}\text { Orion II, 6539. } & \left\{\begin{array}{l}\text { Orion } 4901 \\ \text { Ohio Anna } 10068\end{array}\right. \\ \text { IIabel 22518 } & \left\{\begin{array}{l}\text { Longfellow 6815 } \\ \text { Agnes X 15250 }\end{array}\right.\end{cases}$ 
In making this form of pedigree, the names of the males are at the top of each bracket, and the females at the bottom. This style may be extended from generation to generation, the number of ancestors doubling each remove to the right. This pedigree shows that Orion Chief, a noted Duroc-Jersey, had Orion II for sire and Mabel for dam. Going back another generation, it will be noted that in the line of male descent, his grandsire was Orion and his grandam, Ohio Anna. On the dam's side, Longfellow is his grandsire and Agnes $\mathrm{X}$, the grandam. If we now go back another generation we have four great-grandsires and four great-grandams. This form of pedigree shows the entire direct ancestry, and is the only one generally used by stockmen to show the breeding of an animal.

The line of female descent pedigree is another method of showing ancestry. This may be illustrated by the following Shorthorn pedigree:

I.ip. Villager 295854.

Roan; calved March 1, 1906. Bred by C. H. Jolliffe, Darlington, England.

Dams Breeders of daM Sires Breeders of sires

\begin{tabular}{|c|c|c|c|}
\hline Rosy Cloud (Vol. 50E) & C. 11. Jolliffe & $\begin{array}{l}\text { Village Beau } 295 \$ 93 \\
\text { Chorister } 295852\end{array}$ & $\begin{array}{l}\text { Wm. Duthic } \\
\text { Wm. Duthie }\end{array}$ \\
\hline osy Dawn........ & C. 11. Jolliffe & Misty Morning 153603 & Wm. Duthie \\
\hline ose Blossom....... & S. Cainploell & Clan Alpine 1305.52 & Messrs. Nulson \\
\hline oselinty $\ldots \ldots \ldots \ldots$ & s. C & & A. Cruickshank \\
\hline & S. $C$ & r 96034 & $W_{\mathrm{m}}$. Duthic \\
\hline oan Roschud & S. Campbell & aber 64572 & J. Howman \\
\hline & S. $\mathrm{C}$ & $(2289.5)$ & R. Booth \\
\hline & S. Car & Dip & \\
\hline osebud ............. & S. Campbell & Scarlet Velvet (16916) & A. Cruickshank \\
\hline
\end{tabular}

This pedigree shows the bull Villager to be sired hy Village Beau, a bull bred by William Duthic, a noted scoteh 
breeder. Villager's dam is Rosy Cloud. She was bred by C. H. Jolliffe, and her sire was Chorister, also bred by William Duthie. The grandam of Villager was Rosy Dawn; his great-grandam, Rose Blossom; his great-great-grandam, Roselinty; etc. This pedigree goes back ten generations, showing only the ancestry of Villager on his mother's side, with the sire of each female in this breeding. Except for the sire, the ancestry on that side of the pedigree is entirely left out, while only a part of the breeding on the dam's side is given. While it is true that the dam's pedigree is thus carried out much farther than in the bracket form, what one should know most about is the near relationship all through, at least four generations. A Shorthorn pedigree of this form shows the tribe or family to which the animal belongs, which in this case is the Rosebud, which started in the herd of S. Campbell, a famous breeder of Kinellar, Scotland. In reference to this pedigree, after the name of each male a number is given. This indicates his registry number in the Shorthorn herd-book. When written in parenthesis, it is the English Shorthorn Herd-Book number. Formerly only the herd-book volume and page was given for Shorthorn cows, but now the females registered in America are given numbers, as is customary with all other breeds. The line of female descent pedigree is not desirable, and breeders generally should use the bracket form.

The amount of ancestry shown in a pedigree naturally depends upon its extent. The following tabular statement is given by Davenport,* which shows in a rather striking way the percentages of blood in a pedigree at different points for ten generations.

*Principles of Breeding. E. Davenport, 1907, page 595. 
Relative intensity of bloxd lines and approximately relative influence of different generations and individuals for ten generations backwards.

\begin{tabular}{c|c|c|c}
\hline $\begin{array}{c}\text { Generation } \\
\text { backwards }\end{array}$ & $\begin{array}{c}\text { Number of } \\
\text { ancestors }\end{array}$ & $\begin{array}{c}\text { Influence of generation } \\
\text { Per eent }\end{array}$ & $\begin{array}{c}\text { Influence of each } \\
\text { individual. } \\
\text { Per eent }\end{array}$ \\
\hline 1 & 2 & 50.00 & 25.00 \\
2 & 4 & 25.00 & 6.25 \\
3 & 8 & 12.5 & $1.56+$ \\
4 & 16 & 6.25 & $0.39+$ \\
5 & 32 & 3.125 & $0.10-$ \\
6 & 64 & 1.5625 & $0.024+$ \\
7 & 125 & 0.75125 & $0.005+$ \\
8 & 256 & 0.390625 & $0.001+$ \\
9 & 512 & 0.1953125 & $0.0004-$ \\
\hline 10 & 1024 & 0.09765625 & $0.0001-$ \\
\hline Total & 2046 & 99.90234375 & \\
\hline
\end{tabular}

The statement set forth by this table shows how little influence is derived from one individual in the ancestry ten generations back. Yet the value of blood lines depends also on the character of the breeding. If the ancestry is pure, and contains the names of animals of distinction within the same family lines, then it will mean much more to the breeder who understands pedigrees, than it will if the inheritance shows no family names of value.

The merit value of a pedigree is receiving more and more attention. By merit value is meant the number of animals in the pedigree that show producing records of some kind.

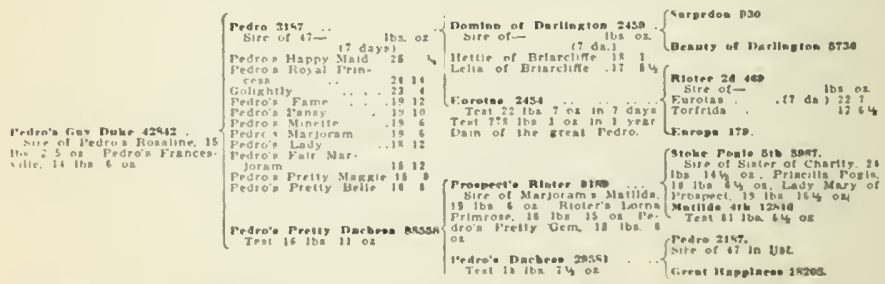

Fig. 147. The pedigree of a son of the noted Jersey bull Pedro, showing merit in three generations on both sides. From a sale catalogur. 
If one studies the pedigree of a race horse, he should find therein the names of many animals with speed records to their credit. In the case of a dairy breed of eattle, then milk or butter-fat records may be given, as well as the records of offspring of sires and dams. With some breeds, a statement is affixed showing prizes won in the show ring. In cases of animals selling at high prices, these facts are also sometimes inserted in the pedigree. The imjortant thing is to show at different points in the ancestry the richness of the pedigree in production. At the present day, one should have no difficulty in securing the pedigrees of pure-bred animals that will give more or less specific information regarding performance on the part of individuals in the pedigree. The richer the ancestry in record-making achievement, the higher the price one must usually pay for the animal purchased.

A pedigree score card suggesting the relative importance of near and remote ancestors has been proposed by Prof. F. R. Marshall.* In this score card, 24 points are given the sire (12 for siring good stock, and 12 for individual merit), and 24 points are given the dam (10 for her record as a producer, and 14 for individual merit), with 4 points on similarity of type of sire and dam. The grandparents are given a total of 24 points, ranging from four to two points each for records as producers, and individual merit. The great-grandparents are accorded one point each on production, individuality, and ancestry. This is an interesting score card, that may come into considerable use.

The accuracy of the pedigree is of first importance. It may not be accurate for two reasons; first, because of errors in writing it, due to carelessness or otherwise; and second, from dishonesty. Mistakes win occur among the

\footnotetext{
*Breeding Farm Animals, 19II, page 110.
} 
most careful and conscientious. The published herd-books of registry associations have in the past contained many errors, although conditions now are greatly improved. Then honest men have copied from sale catalogues pedigrees that contained mistakes, and have republished these errors. The most unfortunate pedigree is the "doctored," or crooked, one. Fraudulent pedigrees exist, and men have on more than one occasion been prohibited from doing business with registry associations on account of fraud. If guilty, the penitentiary is what they deserve. Integrity is the foundation on which the pure-bred live-stock business is based, and all known eases of fraud should be regarded as of eriminal character, and be punished accordingly.

A study of the pedigree is a necessity, if one is to become a successful breeder of pure-bred stock. There are several ways by which one may become familiar with pedigrees. Suppose one is to breed Jersey cattle. Then, if in the business in a serious way, he should try and secure the herdbooks published by the American Jersey Cattle Club. These are the original source from which all Jersey pedigrees are made up in the United States. Having these books, one may at any time trace the pedigrees of registered animals. Sale catalogues should be saved by the breeder, for they will often be found valuable for referenee, even though some of them are earelessly prepared. The register of merit should also be kept for reference, so that information may be at hand regarding official records of production. One also should read the current literature regarding the breed. Some of the more important breeds are represented by special journals, which contain a large amount of information concerning animals of distinction. By these various methods one may accumulate much knowledge regarding pedigrees of animals. 


\section{IN MAKING A STUDY OF THE PEDIGREE}

1. What does it show?

2. What is a grade or high grade?

3. Explain the bracket form and its value.

4. What is meant by line of female descent?

5. How many ancestors does one have in the fifth generation back?

6. How important is the blood influence of an animal ten generations back?

7. What is merit value of pedigrec?

8. Describe a pedigree score card.

9. Give two causes of inaccurate pedigrees?

10. How can one become familiar with pedigrees?

\section{CAN YOU BRING TO THE CLASS}

11. The pedigree of an animal with which you are acquainted?

12. An example of a bracketed pedigree?

13. A sample of a Shorthorn pedigree?

14. Pedigree showing merit, or performance, of

(a) Dairy cattle?

(b) Race horses?

15. A sale catalogue showing prices paid for animals?

16. A pedigree containing an error? 


\section{CHAPTER XVI}

\section{SUGGESTIONS TO YOUNG BREEDERS}

A knowledge of the principles of breeding is desirable for breeders generally. This knowledge is important, no matter what kind of stock one wishes to produce, for only by intelligent application may one become best qualified as a breeder. Therefore the student should keep in mind that no matter in what kind of stock he is interested these pages are intended to serve as a help in the development of the herd. In this connection, there are certain things that may well be emphasized in starting out in this work.

Breed for a special purpose. The successful breeders of the world have always been specialists. The first thing to be considered is the purpose for which the animals are to be produced. One may have in mind meat, milk, speed, or draft, but he should recognize that whether dealing with breed or type, the final aim is some form of production. A multitude of examples illustrating the policies of successful stockmen might be given to show the results secured through breeding for special purpose.

Stick to a well laid out policy. The breeders who have made the most out of their efforts have been persistent, and have staid by the kind of stoek with which they began. The one who endeavors to keep only a class of stock that is selling at high prices, unloading at times of depression of values, rarely succeeds. Every business, including the live-stock business, goes through periods of prosperity and of low values. Take sheep for example. They fluctuate in a wide range of values, and some men dispose of their entire flocks when 
sheep are very low in price. Investigation, however, will show that the man who has staid by his sheep through the years, irrespective of values, has made a good profit on his long-time investment.

Keep a few good animals, rather than many common ones. One may perhaps make money breeding common individuals, but the right kind of reputation comes to a breeder through his best animals. A buyer, as a rule, will

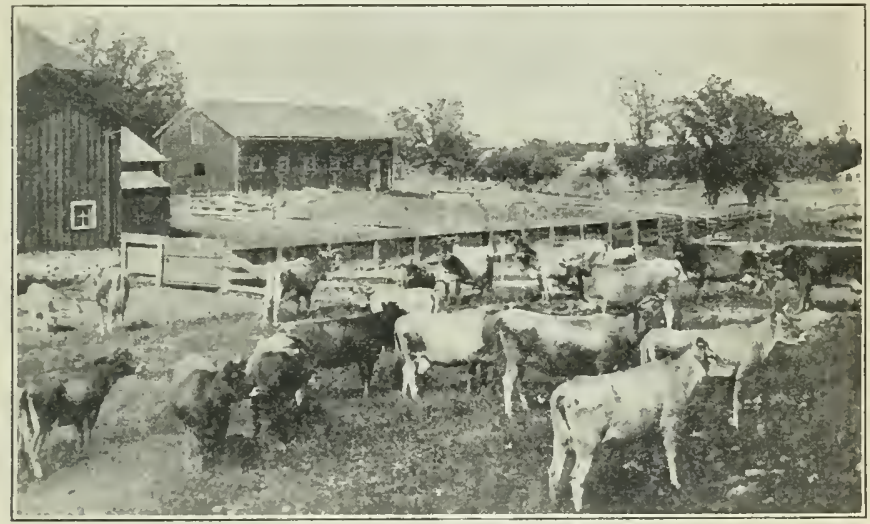

Fig. 148, "Keep a few good ones." Photograph by Prof. John W. Decker.

try to purchase the choicest stock. If the breeder sells these, he will follow the worst possible policy. As has been suggested elsewhere, he would better cull out the undesirable animals and rely on a smaller number of good ones to build up his herd. A group of uniformly good animals, whether grade or pure-bred, is always an attractive sight, and serves as an advertisement of the best kind. A motley herd, lacking character, is not attractive, and hurts the reputation of the breeder. 
Pay a premium on merit when purchasing animals for the herd. Too many breeders buy inferior animals because they are cheap. From a breeding point of view, one should select animals that combine individual merit and pedigree. If there is anything in the laws of breeding that has been helpful in the past, it is the knowledge that like produces like. Each year in the history of a herd should mark improvement, and this cannot be the case if one purchases beasts of an inferior character. The influence of a new animal in the herd is far-reaching, be it good or bad. One should carefully consider this, and be governed accordingly. Some of the most profitable breeding animals in history cost a high price. The Berkshire boar, Masterpiece, was purchased by Mr. Corsa for $\$ 2500$, and proved to be a very profitable animal at that record-breaking price.

Try to become a judge. If one is to be a breeder, he should be familiar with the relation of form to purpose, and should be judge enough to seleet intelligently his own breeding stock. There are courses of instruction whereby systematic training in judging may be secured. Good judgment in culling out the undesirable animals from the herd, and in the purchasing of new stock, is highly essential, whether for breeding or feeding purposes. Some practical feeders have the reputation of shipping only good fat-stock to the market, and buyer's are always on the lookout for animals fed by them, for which they pay the top price of the day.

Feed your animals well. One camnot purchase highclass stock and keep them in good form and state of development, unless properly fed. Many persons buy animals in good condition, but neglect them after the animals come into their possession. Where men must buy feed, they too frequently neglect to give their new purchases enough to keep them in thrifty, healthy condition. Food is essential 
to maintain life and produce growth and vigor. It is a serious mistake to be niggardly in the use of feed. Furthermore, no herd can do other than go backward, if the animals are not fed wisely. Young growing stock, starved and neglected, become inferior in development, and in dueseason naturally reproduce inferior offspring. A true stockman always enjoys seeing his animals eat, and realizes that something is wrong if they do not show a hearty appetite.

Do not be led astray by fads. Develop a herd that combines the useful and beautiful in the highest possible degree, for these two important features naturally go together. Leave out of consideration pedigrees that do not stand for merit. Remember that peculiarities of form often are of little real value, and that it is not wise to go to extremes in these things. Do not make color a vital thing with those breeds in which variation in this respect occurs. Whether an Ayrshire cow is one-fourth or three-fourths white, is a very superficial matter. Her general conformation, constitution, and producing capacity, are the important subjects to consider, rather than the color fad.

Study your local environment, and learn what class of stock you will be most likely to succeed with on the land and under the conditions which surround you. As a rule, it is best to keep the sort of live stock that is most common in the community. If in any one county in a state there was but a single breed of hogs, for example, with many herds represented, it would result in more buyers coming into that section for this special breed, than would come otherwise. They would visit this locality because the greatest selection of individuals for sale would be at hand within a limited territory. This would save the buyer time and money. It would also be a fine thing for the sellers, because of the number of men coming in to inspect their stock. 
Become acquainted with the families or strains of the breed in which you are interested. It is important to know something of these. Those breeds that are represented by a large number of animals, include families of varying degrees of merit. These family traits may be regarded of much importance, and may greatly affect values. Prepotency, special forms of production, adaptability to certain conditions, temperament, etc., are features one or more of which are stronger in some families than in others. Old experienced breeders who are regarded as successful, consider carefully matters of this sort, and act accordingly.

Cultivate the acquaintance of breeders. The man who would succeed in his business must gather information from every legitimate source. Knowledge is a matter of accumulation. We accumulate through observation and personal contact. We get inspiration from those who succeed. It is a fine thing to enjoy the friendship of men who are leaders in the line of business in which we ourselves are interested. Darwin, one of the greatest scientists, gathered a fund of most valuable information from the English stockman and farmer, in whose acquaintance he took great pleasure. Thomas Bates, the noted English Shorthorn breeder, received much inspiration from his acquaintance with the Colling Brothers, men who were doing much for these cattle while Bates was yet young. Furthermore, co-operate with your brother breeder's in a generous way for the promotion and uplift of live-stock interests, whereby all will be benefited.

A private herd record should be kept by every stockman owning a breeding herd. Such a record should contain a list of the animals in the herd, giving their eorrect names and registry numbers, dates of birth, names of sires and dams, and of the men who bred them. A reeord should also be 
kept of all animals produced on the farm, with facts of their parentage. There are private herd-books especially arranged, providing blank spaces for the various facts of importanee, that can be purchased at a reasonable price. If desired, one can prepare his own style of private herdbook. The records which go in such a book are most important, and all men engaged in breeding should feel it a duty to keep them with eare.

Methods of doing business with registry associations should be considered by the breeder. Each breed is. represented by an association of men who prescribe the methods of registry and transfer of animals of that breed. It is the business of the secretary to furnish breeders with blank forms which they may fill out and file with the association, whereby they may register their stock from time to time. The seeretary also furnishes the necessary rules and regulations for doing business with the association. It is not.necessary for a person to be a member of an association for promoting and registering a breed, but it is desirable that he should be. As a rule, members of registry associations do business with it for about half the cost to outsiders; and if one registers many animals, he would soon cover the cost of membership, which varies with the breeds, from $\$ 5$ to $\$ 100$.

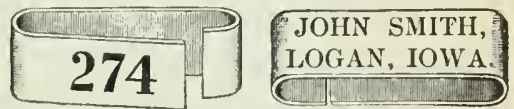

Fig. 149. The Dana ear tag.

The identification of breeding stock on the farm is important. For this reason various methods are used to mark animals so that they can be identified. Metal ear tags, on which is stenciled the name or initials of the owner, with a number, is in common use. Such a tag is fastened in the ear, a hole being punched through which to pass a part of the tag. These tags are often torn out and lost, and so are 
not altogether popular. The tatooing of numbers within the ear, by means of a special needle and an indelible fluid,

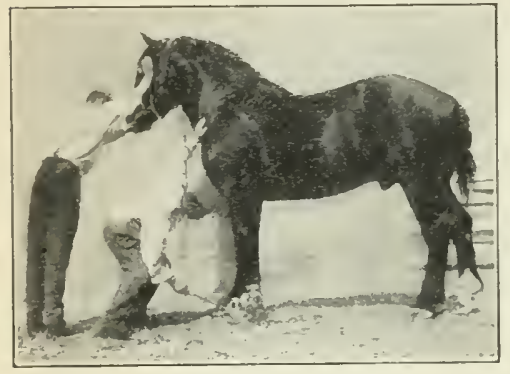

Fig. 150. Branding numbers on the hoof. Photograph by the author. is also used to some extent. Hogs and sheep are commonly identified by notches cut in the thinner edge of the ear, although metal tags are also frequently used with these animals. The hoofs of horses are also stenciled with numbers, especially in case of importation. Sometimes the horns of cattle are marked in a similar way. On the ranges, cattle and horses are branded, and sheep are given marks with paint, by which ownership may be identified. Some of our breeds of dairy cattle, especially those of different body colors, are identified by the location of color marks on the

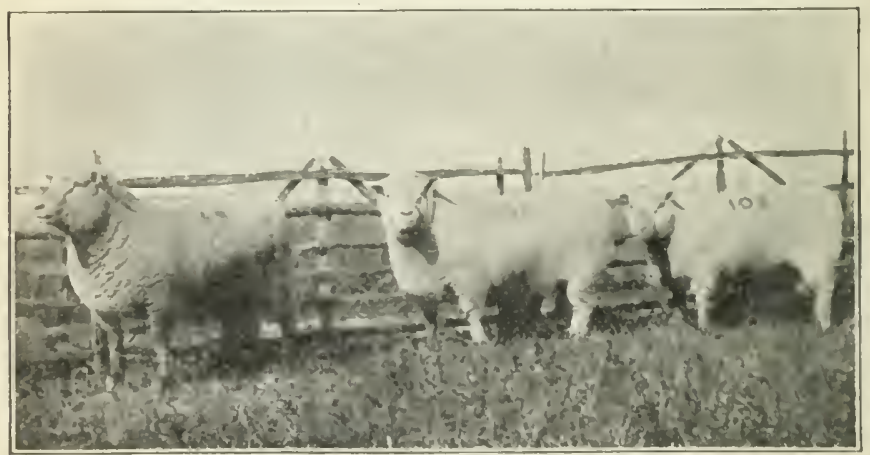

Fig. 151. Southdown rams at Babraham, England, showing method of marking. Photograph by the author. 
body. For example, when applying for registry of a Holstein-Friesian, it is neecssary to trace on a diagram showing the outline of body form, the shape or outline of each black spot, or marking. A copy of these outlines is made on the certificate of registry, so that identification is made easy. Every breeder, as a matter of good policy, should have a system of individual identification of the animals in his herd.

The use of literature relating to the breeds is to be highly commended. Periodicals are published exclusively in the interests of eertain breeds, and most of these deserve support. Real live-stoek students will make it a point to obtain books on breeding and on the breeds, and each will seeure such information as ean be obtained regarding the development of his favorite stock. The herd-books issued by the breed assoeiations should also be on the book shelves of the stockman, for they are invaluable in tracing up blood lines and in studying pedigrees.

\section{AS A MATTER OF GOOD BUSINESS}

1. What reasons can you give for an established policy?

2. Give an example of paying a premium on merit.

3. Has feed much to do with herd improvement?

4. Explain the meaning of a live stock "fad."

5 . Why cultivate the aequaintance of breeders?

6. What advantage is there in the private herd-book?

7. Why be a member of a live-stock registry association?

8. Specify three kinds of identification marks for live stock.

9. What forms of literature are available for the stoekman?

\section{FIVE INTERESTING THINGS TO DO}

10. Locate the man who has dealt in some one kind of live stock longer than anyone else in your seetion, and report on his methorls, after making him a visit. 
11. Report on the most uniform herd within five miles of school, giving facts of interest.

12. Make a sample page for a private herd record and bring to class.

13. Secure and bring to class samples of blanks for registering and transferring animals of some one breed.

14. Report on methods of identifying stock used by different stockmen in your community. 


\section{CHAPTER XVII}

\section{THE COMPOSITION OF PLANTS AND ANIMALS}

The plant as a source of food is of great interest to feeders of live stock. All our farm animals eat green plants with relish, just as a man enjoys celery. When plants are properly dried and cured as hay, their value for feed is not thereby affected. All of our grains are products of plants; and from these directly, or indirectly by milling, do we obtain some of our most valuable feeds for farm animals. So the facts are that the plant, in one form or another, really furnishes our horses, cattle, sheep, swine, and poultry with about all of their food.

The material of which plants are made is taken from both soil and air, but largely from the soil. Like animals, plants must have food. The chemist tells us that all matter is composed of elements, about 13 of which provide food for the plants. The names of some of these are common, such as iron, sulphur, and phosphorus. There are four others:
Carbon
Oxygen
Hydrogen
Nitrogen

that are also important. Besines these, the plant needs potassium, calcium, sodium, magnesia, chlorin, and silica. Most of these elements are found in different combinations in the soil, more or less dissolved in the water. By means of its roots, the plant takes up the water and so carries this food through all its various parts. As this water or sap moves through the structure of the plant cells, the food in solution is used to promote growth. Carbon, oxygen, hydrogen, and nitrogen are gases in the air. The first two 
of these unite to form carbon dioxide, or carbonic acid gas, which the plant breathes in through the pores of the leaves. This gas in the plant goes through a change, and the oxygen is breathed out, and the carbon is left to be made up into the solid part of the plant.

Nitrogen in the form of a compound is taken up by the plant through its roots; but plants of the legume group, such as the clovers aided by certain bacteria, have the power of using the nitrogen in the soil atmosphere. Nitrogen is a highly valued plant food, and the farmer often purchases it in fertilizer at a good price. These different elements unite with one or more others in the plant, and form combinations which are familiar to us under various names. Of these, the following are important when we come to consider the plant as food.

Water is a combination of hydrogen and oxygen. It is found in all plants, and even in very dry hay. To get the water entirely out of the plant, it must be driven out with artificial heat. The amount of water in plants differs greatly. Common timothy hay and red clover contain about 15 per cent, and ordinary corn meal has a similar amount. About 80 per cent of green pasture grass is water, and some of our roots, like the turnip, have 90 per cent. After the water is driven from the plant by heat, what is left is dry matter. The water in the plant is worth no more than any other water, its ehief value being to carry food in solution through the plant.

Ash, or mineral matter of plants, we see in the ashes left from burned wood. When we burn a plant, we destroy its form, and all that which burns and disappears we call organie matter. That which is left is ash, or inorganic matter. There is much difference in the amount of ash in plants. Green or very young plants contain the least, and 
old ones the most. Common corn fodder contains about 3 per eent of ash, alfalfa about 10 per eent, and some of the roots 1 per cent. The ash in plants is of value for food, if not too abundant. Hogs raised on feeds containing but little mineral matter, such as corn, for example, do not have as good bone or do not feed so well as when the corn is supplemented with other feeds containing more ash.

Protein in the plant is a combination in which nitrogen, especially, plays a very important part, and is combined with carbon, oxygen, hydrogen, and sulphur. There are different forms of protein, but we do not need to concern ourselves about that here. This substance is not usually abumdant all through the plant. Rough stalks contain but little. Prairie grass hay has about 6 per cent, red elover 12 per cent, and cotton seed $181 / 2$ per cent. The growing plant usually has its greatest amount of protein when in bloom. Seerls are richest in this substance, for as the plant matures it shifts the protein to some extent from stalk to seed. In some of our mills where seeds are crushed or otherwise treated and the hulls removed, by-products, very rieh in protein, are produced. Cottonseed meal is a good example. Protein, whether used to feed plants or animals, is the highest priced food constituent the farmer can buy, when we consider the price he must pay on the market. This is because it contains so much of the valuable element, nitrogen.

The carbohydrates are combinations of carbon, hydrogen, and oxygen, and contain no nitrogen. These are the most abundant of our food substances in plants. There are two kinds of carbohydrates, one known as nitrogen-free extract, consisting mostly of sugar, stareh, and gums; the other called fiber or crude fiber, making up the woody part of the plant. Most of the fiber is cellulose, the material composing the 
walls of plant cells. The chemist may dissolve out the starch and the sugar from the plant cells; what is left is the fiber. The starch, sugar, and fiber are all carbonydrates, but the first two are much better for food, as they are very much more easily digested than the fiber. In general we see carbohydrates all about us in plants and plant products. The most of the stalk of corn, or any growing plant, consists of carbohydrates. Common rice and potatoes are rich in this substance. Many of our hays eontain from 60 to 70 per cent; therefore this is the cheapest as well as the most common constituent of animal feeds. Animals cannot subsist on earbohydrates alone, although they are very valuable as a source of heat and energy. However, the farmer must depend largely on materials rich in these substances to supply the great bulk of the feed for his stock.

The fat in the plant is composed of earbon, oxygen, and hydrogen in different combinations from which we find them in the carbohydrates. Fat, or ether extract, as it is also called, is not usually abundant in plants. One to 3 per cent is the usual amount with many plants. The seeds ordinarily contain the most, some of these like cottonseed and flax having large quantities, so that it is extraeted for commercial purposes, and the by-product rich in protein is sold as cake or meal. Fat is of special value in the food, as it furnishes the animal both heat and energy.

The words roughage and concentrate are commonly used today by persons referring to feeding stuffs. When a farmer speaks of roughage, he means hay, corn fodder, or some eoarse feed of that kind. By a concentrate, he means sceds that may be fed, or products made from them, such as bram, corn meal, oil meal, ete. Any form of feed for farm animals that eontains mueh protein is usually considered a coneentrate. 
The following arrangement will show how the parts of the plant are related to one another:

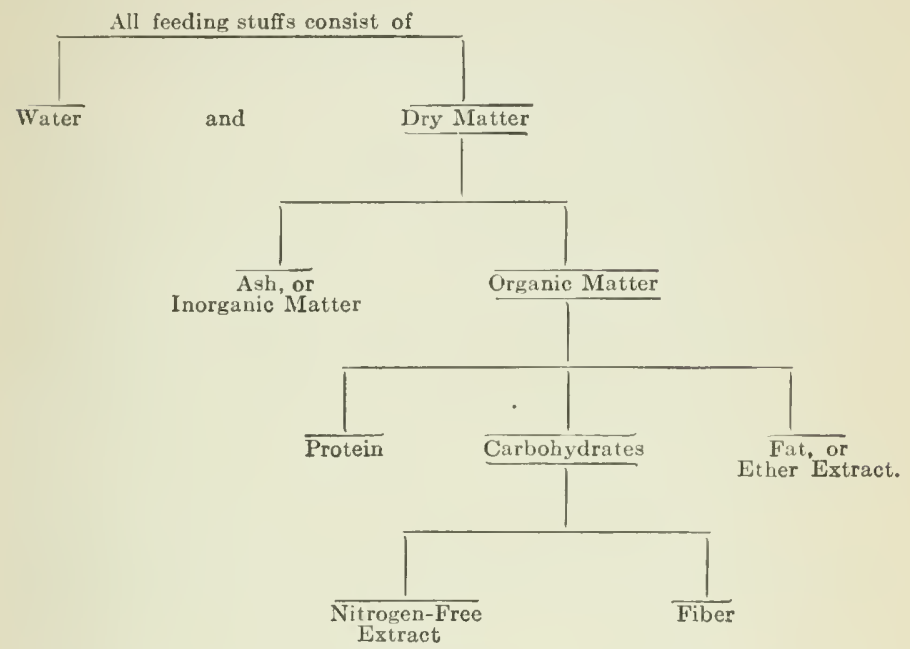

The material of which the animal is made is very similar to that used in building plant tissue. To begin with, the body of the animal is made up of water and dry matter. If we remove the water, dry matter is left. If this is burned cntirely so that even the charcoal is destroyed, the organic part disappears and only ash is left. The organic matter, while made of chemical substanees similar to those found in plants, consists mostly of protein and fat, with but little of the carbohydrates. The composition of the animal body may well be studied a little more in detail.

Water in the animal body is found in the blood, and in the fleshy and bony parts. The amount of water in the animal depends upon age and condition. Young animals have rather watery bodies. The older an animal becomes, or the 
fatter he gets, the less water is found in the body. For example, a calf a week old may consist of 60 per cent water, while a fat cow four years old may be but 45 per cent water. It will be fairly accurate to say that about 50 per cent of the body of an animal under usual conditions is water.

The mineral matter, or ash, in the animal is more or less abundant, according to age and condition. Old animals always contain more than do young ones, and fat less than lean ones. Usually we find a little over three pounds of ash for each 100 pounds of body weight. A fat, corn-fed hog, however, may be so short of ash in the body that the bone will hardly be strong enough to support its weight. The ash in the animal is made of the same substances as that found in plants.

The protein of the body is to be seen in the form of muscles, tendons, blood, nerves, the internal organs, hide, hair, horns, etc. Lean meat with no fat on it is protein, or nitrogenous material. The fatter the animal, the less the percentage of protein in the body. In the entire body of a farm animal under usual conditions we find about 13 or 14 per cent protein. In the dressed carcass, ready to be sold for meat, we find about 17 per eent.

The fat of the animal body is composed of carbon, hydrogen, and oxygen, or of the same chemieal substances as the fat of plants, but differing in combination. The amount of fat in the body depends much on how an animal has been fed. If we take a young growing pig, the body may contain only 25 per cent fat, or even less, but a hog that has been well fattened and is ready for the buteher may contain over 40 per cent. Not often do we find less than 6 per cent fat in the body, or over 35 per cent. In the earcass ready for eutting up in the shop, we find about 20 per cent fat, under usual conditions. 
Carbohydrates in the animal body are but contained in it, not a part of it, and so this substance cannot be considered a constituent of animal flesh. However, carbohydrates exist in the body in two forms; one, glycogen, similar to starch in composition, found in the liver and muscles; and the other lactose, or the sugar of milk, found in milk. Dextrose is also found to a slight extent in the blood and tissues.

Comparing plants and animals, we see that the plant obtains its food from the air and from the mineral matter in the soil, from which it develops a form made up of cells that are largely carbohydrates. The farm animal obtains its nutriment from the plant, from which is created a body form, also composed of cells, but in this case, of nitrogenous material. During the day the plant sucks in carbon dioxide from the air through its leaves, and holds the carbon, and gives off the oxygen. Theanimal, on the contrary, draws the air into the lungs, uses the oxygen from it, and then breathes out carbon dioxide. Thus we see that these two great groups of living matter, the plants and animals, are of vital importance to each other, and have much in common. Without the plant or its products the animal could not live; while by feeding on it, the beast converts the vegetable substance into a yet more concentrated and more valuable material.

\section{REAL FOUNDATION QUESTIONS}

1. Name ten elements, tell where they occur and how taken up by plants.

2. How abundant and useful is water in the plant?

3. Diseuss protein and its oceurrence.

4. What two kinds of earbohydrates are there? Illustrate.

5. Where in the plant is the fat most abundant?

6. What is a concentrate? Give three examples.

7. How mueh water is found in the animal body? 
S. Of what use is the mineral matter in the animal?

9. What percentages of protein and fat are found in animals?

10. Where are the carbohydrates found in the animal?

\section{THINGS EASILY FOUND. LOOK FOR THEM}

11. specimens of elements.

12. Organic and inorganic matter.

13. Ashes of different kinds.

14. The protein of plants and also of animals.

15. Five kinds of fat.

16. Roughage and concentrates. 


\section{CHAPTER XVIII \\ THE INFLUENCE OF FOODS ON THE BODY}

In order to understand the influence of food on the body, it will be necessary to consider briefly the simpler features of digestion.

The process of digestion begins with the mouth, where the food is broken up and softened. The fluid called saliva flows from small glands at the base of the tongue, and the mixing of this with the food in the mouth is called insalivation. This fluid contains substances which act on the starch in the food and help change it to sugar, so that it may be absorbed more readily. In swallowing, the food passes from the mouth through the aesophagus, or gullet, into the stomach. The horse and hog have but one stomach, but eattle, sheep, and other animals that chew the cud, have four. The process of digestion, however, is similar in all stomachs. The cow chews a mouthful of grass very imperfeetly at first and swallows it into the paunch, which is the largest of the four stomachs. From here, after more or less mixing, the food is forced into a second and smaller stomach, called the honeycomb. After it has been churned about and softened in these two stomachs, the animal forces back into the mouth as frequently as desired, a small amount of food called the "cud," for further chewing. The cattle-man calls this operation "chewing the curl." After a bit this is returned, and by a special movement, passes into the manyplies, or small third stomach, from which it passes on into the fourth, or true stomach. While in the true stomach the food is churned about and mixed with 


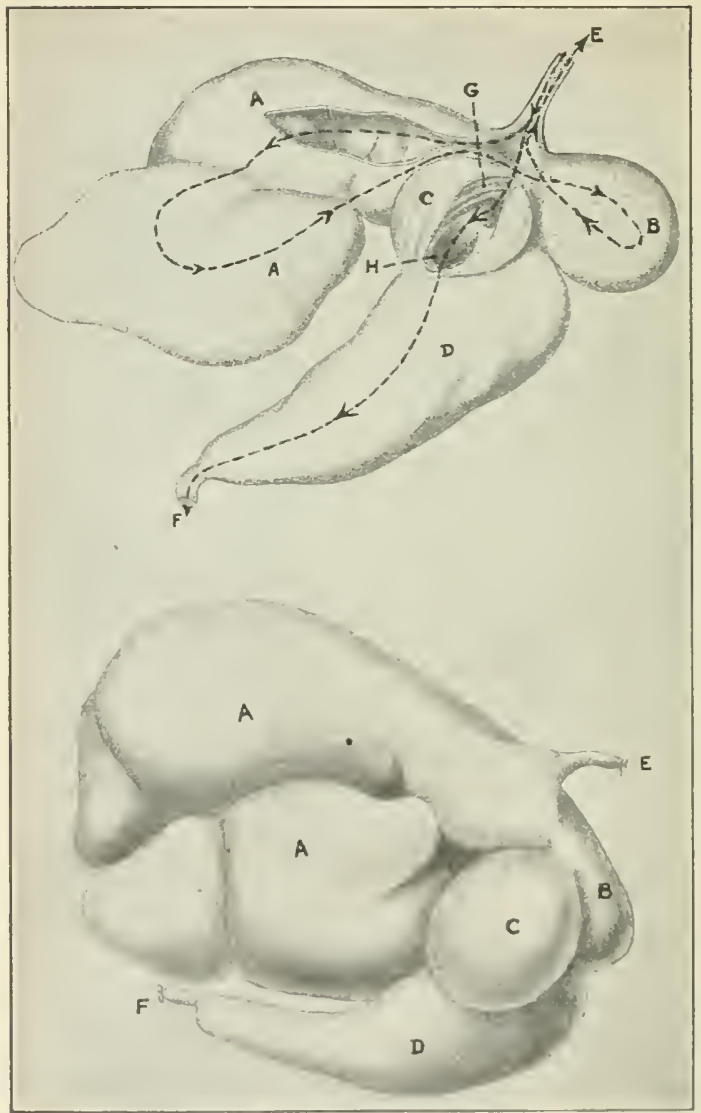

Fig. 152. The stomach of cattle. The lower figure ghows (a) the first stomach, (b) the second, (c) the third, and (d) the fourth. The upper figure shows by the dotted lines the direction of moveruent through the four stomachs. Figures reproluced from "Cattle and their Diseases," U. S. Dept, of Agriculture. 
gastric juice, which contains a little acid. These juices act on the food, dissolving and changing it so that it can pass through the walls of the digestive tract and be used in the body. From the stomach, by a peculiar wave-like motion, the food is forced on into the small intestines, where it is mixed with other fluids that aid digestion. The liver and pancreas glands both pour juices over the food as it moves along the way in the small intestine. Thus the food from the time it is taken into the mouth is constantly acted on and changed for use in the body. The material not absorbed from the small intestine is passed on into the large one, where the last changes take place. During this trip in the body the protein, carbohydrates, and fat are broken up into different smaller and simpler particles. When ready to be absorbed, they are taken into the circulation by the blood and lymph, and carried all through the body. Left in the cells, these particles of protein, etc., which are called nutrients, serve their final purpose of building up the body or producing milk or energy. This process of digestion and absorption is rather complicated, and includes many changes that need not be mentioned here.

The size and capacity of the digestive organs are much greater than many suppose. The following figures make this clear:

Capacity of stomach and intestines of Length of intestines

The horse............224 quarts ........... 98 feet

The ox............................. 187 feet

The sheep.............47 " $47 . \ldots \ldots \ldots . .107$ feet

The hog........................ 77 feet

It is to be noticed that the ox has a very great capacity in its four stomachs, the full contents of which will fill a large barrel.

The food in the body is for the purpose of maintaining life, for producing growth or energy, or certain substances, 
of which milk is an example. On this account people who feed live stock must regulate the food in amount and kind if they wish to obtain the best results.

The protein in the food during digestion is acted on by what are called digestive ferments. One of these, pepsin, attacks the protein in the stomach, and hydrochloric acid also takes a part here. These break up the protein into simpler forms, making them suitable for use in the body. After the protein gets into the intestines, two other ferments attack it, and make such changes in it that it is easily dissolved and absorbed, and distributed through the tissues of the body. The animal cannot take the protein in the plant and use it at once as body protein, but it must go through these changes in the digestive organs before it can be used. The protein in the food is changed to body protein, of which lean meat is the best example. To some extent it may also be changed into fat. Animals that depend entirely upon flesh for food can live on protein alone if necessary. During starvation, the body loses a small but rather constant amount of protein. So we consider this substance especially valuable for building up the muscles, the hair, wool, internal organs, blood, and similar tissues.

The carbohydrates in the food are largely ehanged into sugar during digestion. Thus they are more easily absorbed into the body. There are different kinds of sugars, but that in the food is converted into glucose. This sugar is then taken up by the eirculation and carried to the liver, where it is again changed somewhat, and from here is distributed over the body as needed. The earbohydrates are largely used in the system to furnish the energy necessary in work, and to make fat. Interesting experiments with animals, show that more fat is stored in the body than can be supplied by the protein and fat in the food. Dr. Jordan of the 
New York experiment station has clearly proved that carbohydrates are used to form part of the fat in the milk of the cow. If animals are fed enough foods rich in digestible carbohydrates, the fat in the body will not tend to diminish in amount. In other words, such foods protect or conserve the body fat. The carbohydrates are also regarded as great sources of heat and energy. This will be explained a little further on. Feeds containing plenty of carbohydrates cost less for the dry matter in them than do any other feeds, and are valuable for filling the stomach. Sheep and oxen must be fed a quantity of roughage, as a filler, if they are to do well.

The fat of the food when in the small intestine, is changed into soap and glycerin. It is finally taken up in the cireulation, in a changed form, and then stored as a part of the body fat. The fat of the body is usually made from the fat and the earbohydrates of the feed, though it may be produced to a small extent from protein. There is usually but little fat in the roughages fed to stock.

The mineral matter in the food is taken up in the small intestine, and goes through no special digestive changes as with the other food substances. Mineral substances are regarded as of great importance in building up the body. Those foods that contain but little ash give poor results in feeding, unless the necessary material is supplied. Years ago Professor W. A. Henry showed that hogs fed only corn, had bone just about half as strong as hogs fed bone meal or hard-wood ashes with the corn. Farmers give hogs ashes or coal because these animals make a better development when so fed. Without the ash, the body is not given proper nutrition. Corn lacks ash. A hundred pounds of corn meal contains but a pound and a half of ash, while a hundred pounds of oats has more than twice that amount. All stockmen rate 
oats highly for producing hard, strong bone in growing animals.

All food has a heat value, just as coal has. If burned, coal gives off heat; so does food. All heat comes from the sun, and is stored up in the plant, ready to be set free. The word calorie represents a measure of heat given off by food. One calorie equals the amount of heat required to raise the temperature of 1 pound of water $4^{\circ} \mathrm{F}$. The word therm is now being adopted as more convenient for use in referring to stock feeding. A therm equals 1000 calories. If we raise 1000 pounds of water $4^{\circ} \mathrm{F}$, that measures a therm. While food is being digested in the body, heat is produced by the process. Some foods contain more heat than others. The difference will depend largely on the amount of fat contained. Scientific men consider that the heat values of protein and carbohydrates are about alike, but that the heat value of fat is $2 \frac{1}{4}$ times as great as either of these. This partly explains why the Eskimos in the cold north eat so much food that is nearly all fat, as the blubber of the whale. Corn contains more fat that any of our common grains, which accounts in part for its use as a winter feed for horses, and also is a reason why it should not be fed heavily to stock in summer in the warm season.

Food has an energy value. When a substance is burned, the resulting energy furnishes power to do work. So it is understood that what we call a therm represents the energy or work necessary to raise 1530 tons to a height of one foot. Part of the energy of the food, to be sure, is lost in the process of digestion, partly because not all the food is digested. But much of it is saved, and this is used to keep the engine of the body going. The horse that pulls the plow or hauls a load of hay gets his power from the stored-up energy in the food, which is set free in the body during oxidation. 
The heat and energy value of food has been worked out by scientific men, by means of a calorimeter. This is a very strong, round, hollow steel tube. A sample of a food is placed in this and burned, and the amount of heat given off . is measured. Another instrument, ealled the respiration. calorimeter, also is used, in whieh a live animal is placed. With this the investigator can study the value of foods, and can make a complete record of just what becomes of all the energy produced. By means of the calorimeter, one measures the heat or energy used in labor, or thrown off from the body, or passed off as breath through the mouth. The application of this knowledge will be found in the next chapter. At the Pemsylvania experiment station there is a respiration calorimeter made to hold animals as large as cattle. In this there have been conducted very interesting experiments on the energy value of foods as fed to cattle under different conditions.

The palatability or taste of food is considered very important in feeding animals. If the food is pleasing to the taste, the animal will digest it better, because the fluids used in digestion will flow more freely, and thus act more completely on the food. Nice sweet hay is greatly relished, while that which is somewhat mouldy, or las not been properly ripened, or cured, will be poorly eaten or entirely refused. The animal that feeds best has a good appetite, and eats plentifully. A great Russian experimenter, who studied the effects of the appetite on the forming of the digestive fluids in dogs, learned that digestion, appetite, and palatability all go together.

The use of water by the animal is very important. Water may keep the entire body in a healthy condition. The digestive fluids and blood need given amounts of water to do their work right, and water is needed to keep the 
intestines open and active, and to regulate body temperature. Experiments have shown that farm animals need a certain amount of water for every pound of dry matter eaten. For example, a horse or sheep needs from two to three pounds of water for each pound of dry matter eonsumed. With some foods more water is required than with others. The cow that eats silage will drink but little water compared with the one fed dry corn fodder.

The nutritive ratio is frequently referred to in discussing the use of rations in practical feeding. This term is used to express the ratio of the digestible protein to the digestible non-protein substances in the food, or the combined carbohydrates and fat to the protein. In order to compare these substances on an equal basis, they are reduced to the same heat valuation. Protein and the carbohydrates do have the same heat value, but a pound of fat is equivalent to about $21 / 4$ pounds of either one of these. Consequently the chemist, in order to place them on an equal footing in heat value, multiplies the digestible fat by $21 / 4$. The mutritive ratio is found by adding this to the amount of the carbohydrates, and then dividing the sum by the digestible protein content. The following example will illustrate the method of finding the nutritive ratio:

Oats contain 10.7 pounds of digestible protein, 50.3 pounds carbohydrates, and 3.8 pounds fat. Then the ratio is worked out in this manner. 3.8 pounds fat $\times 2 \frac{1}{4}=8.55$ $=$ the carbohydrate equivalent of the fat.

$$
\begin{gathered}
50.3+. .55=5 S . S 5 \\
10.7) \underset{5.5 .5}{5}(5.5 \\
53.5
\end{gathered}
$$


The nutritive ratio is obtained in the same way for an entire ration, dividing the total amount of the digestible carbohydrates and fat by the total digestible protein. A ratio of 1:5.5 means that for each pound of digestible protein in the ration there are 5.5 pounds of carbohydrates or its equivalent.

A narrow nutritive ratio is one in which the amount of carbohydrates and fat is not large in proportion to protein, such as $1: 3$, or $1: 5$; a moderate amount would be $1: 8$; while a wide ratio would be 1:12. Highly concentrated foods usually have narrow ratios; while coarse foods, such as roughages, have wide ratios.

\section{DIGEST THESE QUESTIONS}

1. What is meant by "chewing the cud?"

2. How is food taken into the circulation?

3. What is the capacity of the stomach of the ox?

4. What digestive fluids are present in the stomach?

5. How are the carbohydrates changed in digestion?

6. What is a "calorie"? a "therm"?

7. How can the energy value of food be shown?

8. Describe the calorimeter.

9. What has palatability of food to do with digestion?

10. Explain the term "nutritive ratio."

\section{TAKE NOTE OF THESE THINGS}

11. How often does a cow chew the cud? Watch and see.

12. If an opportunity occurs, measure the intestines of an animal that may be killed on the farm. Report.

13. Get samples of what you consider palatable and unpalatable foods for stock.

14. Figure out the nutritive ratio of three plants or other feed materials. 


\section{CHAPTER XIX}

\section{FEEDING STANDARDS: THEIR ORIGIN AND USE}

The chemical composition of a feeding stuff is easily learned by a chemist. He takes a fair sample of the feed and grinds it in a mill to a powder as fine as flour. He then takes a small sample of this and analyzes it in the laboratory. $\mathrm{He}$ dries a weighed portion in an oven and finds just how much water it contains, and what the percentage of dry matter. Then with ether he dissolves out the fat, (ether extract) and weighs this. With other chemicals he also separates out the protein, the nitrogen-free extract, and the fiber. Another sample of the feed he burns to learn how much ash or mineral matter remains. Thus the chemist is able to determine just how many pounds of each of these substances there are in a giren amount of feed. This is the first step taken by the chemist in studying the value of foods for animals.

The amount of digestible nutrients in a food, the simple chemical analysis, however, did not show. This led to another step forward by the chemist, whereby he learned just how much of the total protein, carbohydrates, and fat in a given food an animal cligested. After analyzing a sample of the feed, as much of it was fed as the animal would eat in a given time. During the experiment, all the solid and liquid excrement passed off by the animal was collected, and samples of these were also analyzed. Having leamed how much protein, carbohydrates, and fat were lost in the manure, the chemist deducted these amounts from the total amounts eonsumed in the feed, and the difference was considered the amount digested by the animal. This method was not perfect, but 
it was a great step in advance. It enabled chemists to figure out the amount of each nutrient digested under different conditions, so that in time they were able to prepare for the use of farmers what is called "a table of digestible nutrients." This table showed the total amount of dry matter in 100 pounds of different kinds of feed, and also the number of pounds of digestible protein, carbohydrates, and fat in every 100 pounds. In this table, for convenient reference, foods of similar sorts are grouped by themselves. For example, roughage is all classed together, and this is divided into three groups: as dried roughage, fresh green roughage, and roots and tubers. Then the concentrates are arranged by themselves, and these are also divided into groups. The following is taken from a table of digestible nutrients, * and is used here to illustrate what has just been explained. No attempt, however, is made to group these feeds.

\begin{tabular}{|c|c|c|c|c|}
\hline \multirow{2}{*}{ Name of feed. } & \multirow{2}{*}{$\begin{array}{c}\text { Total dry } \\
\text { matter in } \\
100 \mathrm{lbs}\end{array}$} & \multicolumn{3}{|c|}{ Digestible nutrients in $100 \mathrm{lbs}$. } \\
\hline & & Protein & $\begin{array}{c}\text { Carbohy- } \\
\text { drates }\end{array}$ & Fat \\
\hline Corn meal. .... & 85.0 & 6.1 & $6 \pm .3$ & 3.5 \\
\hline Wheat bran............ & 88.1 & 11.9 & 42.0 & 2.5 \\
\hline 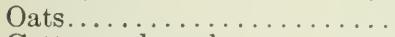 & 89.6 & 8.8 & 49.2 & 4.3 \\
\hline Cottonseed meal. & 93.0 & 37.6 & 21.4 & 9.6 \\
\hline Timothy hay .......... & 86.8 & 2.8 & 42.4 & 1.3 \\
\hline Kentucky blue grass hay. & 86.0 & 4.4 & 40.2 & 0.7 \\
\hline Wheat straw........... & 90.4 & 0.8 & 35.2 & 0.4 \\
\hline Red clover-green.......... & 29.2 & 2.9 & 13.6 & $0 . \overline{7}$ \\
\hline Alfalfa-green............ & $2 S .2$ & 3.6 & 12.1 & 0.4 \\
\hline
\end{tabular}

This little table, which is made from a much longer one giving the digestible nutrients in about all the different kinds of food the American farmer is likely to feed, shows that 100 pounds of corn meal contains 85 pounds of dry matter. In this 85 pounds, of the digestible material of use to an

*Feeds and Feeding. W. A. Henry, 1912. 
animal, we find 6.7 pounds of protein, 64.3 pounds of carbohydrates, and 3.5 pounds of fat. Let us now look back and learn how figures like these have a practical value to the farmer.

The kind and amount of food required by an animal very naturally depends on the class to which it belongs, its age, and use. No one would expect to feed a calf the same as a horse, or a sheep like a mileh cow. Each must be fed so as to supply its needs as completely as possible. As might be expected, scientists were a long time getting the necessary information to enable men to understand how to feed so as to get the best results.

What we know as feeding standards, in the beginning were very simple and did not have any real value. The working out of useful standards began in Germany, and German chemists have done more than any one else to furnish us knowledge on this subject. The first plan attempted was to give meadow hay a fixed value, and then measure up other feeds with that as the standard. That plan originated about 1810. Some fifty years later, another German chemist suggested that animals be fed special amounts of protein, carbohydrates, and fat, according to certain conditions. However, his plan was not good, because he did not take into account the digestibility of the food. He was able to analyze a food, but he knew nothing of how much of each nutrient the animal digested. At that time there was quite a deal of information of the ehemical composition of feeding stuffs, but the digestibility of the foods had not been figured out. Then about 1864, another German ehemist, by the name of Wolff, proposed that animals be fed daily eertain amounts of digestible protein, earbolydrates, and fat, such as were actually repuired by the animals. Wolff was able to propose this because he had conducted many fecding tests with dif- 
ferent animals, and had learned much of the digestibility of feeds. His studies resulted in what are now known as

The Wolff feeding standards for farm animals. Two things were shown by this great scientist. One was the digestibility of the nutrients in different feeding stuffs, and the other was the amount of each of these required by farm animals under certain conditions. Wolff found that animals that were doing no labor, that were not being fattened, neither gaining nor losing in weight, required only sufficient food to keep the body and the internal organs healthy and vigorous. Such an animal required what he called a maintenance ration. A young animal needed a growing ration, and cattle intended for meat required a fattening ration. A cow produeing a large amount of milk must be fed, first to supply the ordinary needs of the body, such as might be found in a maintenance ration, and besides this, she must be fed still more to enable her to produce the milk of which the food is the source. The dry cow may be satisfied on a maintenance ration consisting of some form of roughage only, such as elover hay for example; but if she is yielding a good supply of milk, then rich eoncentrates must be fed, if the increased demands of milk production are to be met.

Since Wolff first made known this most important discovery, many other chemists have experimented in the same field. Both European and American agricultural chemists have studied the seience of feeding, so that now we know much more than did the student or farmer in the days of Wolff. Animals have been carefully studied, and the invention of the respiration calorimeter has resulted in some wonderful investigations in the fields of chemistry and animal nutrition. The work of Wolff was that of a pioneer. For many years Americans relied on analyses of German feeds, and made use of the standards that came to us from 
Europe. Today we are able to use a table of digestible nutrients which is based on the composition of American feeds as studied by chemists of our own country. Wolff's feeding standards in improved form are, however, very generally used by American feeders as the best yet available. Wolff used 1000 pounds as the standard of weight for animals, and assumed that a certain amount of dry matter, and of digestible protein, carbohydrates, and fat, were needed for that weight under given conditions. The animals were classified in groups, as oxen, fattening cattle, milch cows, sheep, horses, etc. Then those in a group were classified according to their purpose; as for example, horses into light, medium, and heary work; and dairy cows in four classes, according to the amount of milk made per day. The following figures, taken from Wolff's feeding standard, illustrate its arrangement:

Pounds required daily for each 1000 lbs. live weight.

\begin{tabular}{c|c|c|c|c|c}
\hline \hline \multirow{2}{*}{ Kind of animal } & $\begin{array}{c}\text { Dry } \\
\text { matter }\end{array}$ & \multicolumn{2}{|c|}{ Digestible nutrients } & $\begin{array}{c}\text { Nutritive } \\
\text { ratio }\end{array}$ \\
\cline { 5 - 6 } & & Protein & $\begin{array}{c}\text { Carboliy- } \\
\text { drates }\end{array}$ & Fat & \\
\hline Horses, light work .... & 20 & 1.5 & 9.5 & 0.4 & $1: 7.0$ \\
Horses, medium work . & 24 & 2.0 & 11.0 & 0.6 & $1: 6.2$ \\
Horses, heary work... & 26 & 2.5 & 13.3 & 0.5 & $1: 6.0$ \\
\hline
\end{tabular}

This table means, for instance, that a horse at light work woighing 1000 pounds requires 20 pounds of dry matter daily, containing $1 \frac{1}{2}$ pound of protein, $91 \frac{1}{2}$ pounds of carbohydrates, and 0.1 pound of fat, the ration having a nutritive ratio of $1: 7$.

The practical application of Wolff's feeding standards has been recognized on thousands of farms in America, and to the great profit of those adopting them. l'robably no class of prople has studied the standard more carefully than 
feeders of dairy cattle, and it is among herds of this kind that we find Wolff's standards most commonly used. It must be understood that one may not be able to feed his stoek so as to follow the standard perfeetly, but there is no trouble in using it in a practical way as a guide. One may feed a little less or a little more protein than the standard recommends. When the animal is fed about right, according to the standard, then a balanced ration is being used; or one whieh, without waste, most perfectly meets the needs of the body. Many experiments have shown that the balaneed ration can be relied upon for giving the best results.

Energy value feeding standards have recently attracted attention. Kellner, a German, and Dr. H. P. Armsby, a noted American investigator of feeding animals, about 1908 proposed that the feeding value of foods be measured by their energy content, as shown by the therms of net energy they supply. These men aceounted for the loss of a part of the food energy by the animal in the mastication of its food, and in the operations of the internal organs, etc. The energy left after digestion they called the net energy and this was used by the animal for supplying speeial needs. Armsby has published a set of figures showing the dry matter, digestible protein, and net energy value in therms in some of the most eommon feeding stuffs. He has also prepared a maintenance ration standard, and one for growing cattle and sheep. The following is made up from the latter, to show how this energy standard is arranged.

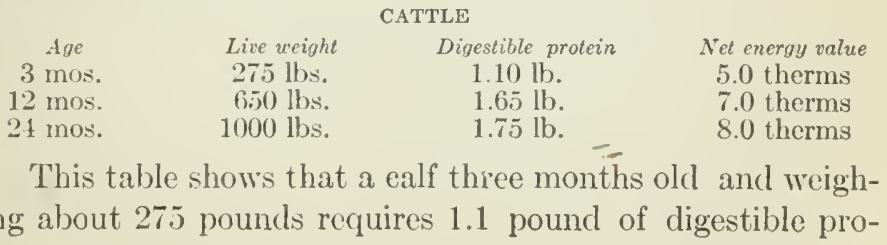


tein per day, and that the total net energy in the ration will equal five therms. This new standard has hardly been long enough before the public to be well known, and has been used but little in practice.

\section{QUESTIONS ON KNOTTY THINGS}

1. How does a ehemist analyze a feeding stuff?

2. What is meant by digestible nutrients?

3. How are feeding tables arranged?

4. Trace the history of the feeding standards.

5. Explain meaning of a maintenance ration.

6. What standard of weight is used in feeding tables? Suppose an animal weighs more or less?

7. Discuss the practical use of Wolff standards.

8. What are the energy value feeding standards? 


\section{CHAPTER XX \\ HOW TO CALCULATE A RATION}

The method of calculating a ration is very simple, and can easily be put in practice by anyone who knows how to add, multiply, and subtract. There is nothing complicated about it. The fact that many farmers with only common school training figure out the rations for their stock, is evidence enough to support this statement. Many men feeding dairy cows study carefully the composition and cost of feeds, and then figure out the best rations available, that will agree as nearly as possible with the standard.

The first step in calculating a ration is to find out the amounts of dry matter, protein, carbohydrates, and fat in the ration one is feeding, or is planning to feed. In this chapter, only the most common feeds used over much of the United States will be considered. We will figure out the ration for a dairy cow weighing 1000 pounds and making about 22 pounds of milk a day. Let us plan to feed this cow a daily ration say of 10 pounds red clover hay, 30 pounds corn silage, 5 pounds corn-and-cob meal, and 3 pounds bran. To use a good system in the starting of the work, we will arrange the different parts in proper order for study, which is as follows:

Ration for 1000 pound dairy cow producing 22 pounds of milk a day.

\begin{tabular}{|c|c|c|c|c|c|}
\hline \multirow{2}{*}{ Feeds } & \multirow{2}{*}{$\begin{array}{l}\text { Dry } \\
\text { matter }\end{array}$} & \multicolumn{3}{|c|}{ Digestible nutrients } & \multirow{2}{*}{$\begin{array}{l}\text { Nutritive } \\
\text { ratio }\end{array}$} \\
\hline & & Protein & $\begin{array}{c}\text { Carbohy- } \\
\text { drates }\end{array}$ & Fat & \\
\hline $\begin{array}{l}\text { Red clover hay, } 10 \text { lbs. } \\
\text { Corn silage, } 30 \text { lbs..... } \\
\text { Corn-and-cob meal,slbs } \\
\text { Bran, } 3 \text { lbs........... }\end{array}$ & $\begin{array}{l}\cdots \cdots \\
\cdots \cdots \\
\cdots \cdots \\
\cdots \cdots\end{array}$ & $\begin{array}{l}\cdots \cdots \\
\cdots \cdots \\
\cdots \cdots \\
\cdots \cdots\end{array}$ & 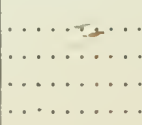 & $\begin{array}{l}\cdots \cdots \\
\cdots \cdots \\
\cdots \cdots \\
\cdots \cdots\end{array}$ & $\begin{array}{l}\cdots \cdots \cdots \\
\cdots \cdots \cdots \\
\cdots \cdots \cdots \\
\cdots \cdots\end{array}$ \\
\hline
\end{tabular}


The second step in calculating the ration will be to find out how much dry matter, and digestible protein, carbohydrates, and fat, occur in each of the amounts of the different feects, and write these figures in the proper blank places in the table. Turning now to page $35 \overline{7}$, in the back of the book, you will find Table A, showing the amount of dry matter and digestible nutrients in 100 pounds of a number of different feeding stuffs. The composition of each of those to be fed this cow can be easily found. Let us take red clover hay for our first calculation.

\section{Red Clover Hay}

Dry matter Protein Carbohydrates Fat $100 \mathrm{lbs}$. contain $84.7 \mathrm{lbs} . \quad 7.1 \mathrm{lbs}$. $\quad 37.8 \mathrm{lbs} . \quad 1.8 \mathrm{lb}$. Then $10 \mathrm{lbs}$. contain $\quad 8.47 \mathrm{lbs} . \quad 0.71 \mathrm{lbs} . \quad 3.7 \mathrm{lbs} . \quad 0.18 \mathrm{lb}$.

Taking corn silage next, we find that

Dry matter Protein Carbohydrates fat $100 \mathrm{lbs}$. contain $26.4 \mathrm{lbs}$. $\quad 1.4 \mathrm{lbs} . \quad 14.2 \mathrm{lbs} . \quad 0.7 \mathrm{lb}$. Then $30 \mathrm{lbs}$. contain $\quad 7.92 \mathrm{lbs} . \quad 0.42 \mathrm{lbs} . \quad 4.26 \mathrm{lbs} . \quad 0.21 \mathrm{lb}$.

Corn and Cob Meal

Dry matter Protein Caribohydrates fat $100 \mathrm{lbs}$. contain S4.9 lbs. $4.4 \mathrm{lbs} . \quad 60 . \mathrm{lbs} . \quad 2.9 \mathrm{lbs}$. Then $5 \mathrm{lbs}$, contain $4.24 \mathrm{lbs} .0 .22 \mathrm{lbs} . \quad 3.0 \mathrm{lbs}$. $0.145 \mathrm{lb}$.

Coming last to bran, we find that

Dry matter Protein Carbohydrates Fat $100 \mathrm{lbs}$. contain $88.1 \mathrm{lbs} . \quad 11.9 \mathrm{lbs} . \quad 42.0 \mathrm{lbs} . \quad 2.5 \mathrm{lbs}$. Then $3 \mathrm{lbs}$. contain $2.64 \mathrm{lbs} . \quad 0.36 \mathrm{lbs} . \quad 1.26 \mathrm{lbs}$. $0.075 \mathrm{lb}$.

If we have copied these figures as soon as worked out, into the blank places fixed for them in the table on page 281 , then we shall have the following, after we have added up the totals: 
Ration for 1000 pound dairy cow producing 22 pounds of milk a day.

\begin{tabular}{|c|c|c|c|c|c|}
\hline \multirow{2}{*}{ Feeds } & \multirow{2}{*}{$\begin{array}{c}\text { Dry } \\
\text { matter }\end{array}$} & \multicolumn{3}{|c|}{ Digestive nutrients } & \multirow{2}{*}{$\begin{array}{l}\text { Nutritive } \\
\text { ratio }\end{array}$} \\
\hline & & Protein & $\begin{array}{c}\text { Carbohy- } \\
\text { drates }\end{array}$ & Fat & \\
\hline Red clover hay, $10 \mathrm{lbs} .$. & S. 47 & 0.71 & 3.78 & 0.18 & \\
\hline Corn silage, 30 lbs..... & 7.92 & 0.42 & 4.26 & 0.21 & \\
\hline Corn-and-cob meal, 5 & & & & & \\
\hline 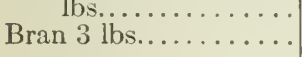 & $\begin{array}{l}4.21 \\
2.64\end{array}$ & $\begin{array}{l}0.22 \\
0.36\end{array}$ & $\begin{array}{l}3.00 \\
1.26\end{array}$ & $\begin{array}{l}0.145 \\
0.075\end{array}$ & \\
\hline Total........... & 23.27 & 1.71 & 12.30 & 0.61 & $1: 8$ \\
\hline Wolff standard....... & 29.00 & 2.50 & 13.00 & 0.50 & $1: 5.7$ \\
\hline A shortage of ...... & 5.73 & 0.79 & .70 & $.11 \dagger$ & \\
\hline
\end{tabular}

†Excess.

If we look in Table B, on page 388 , in the back of this book, we will find the Wolff feeding standards for some of the different farm animals, with 1000 pounds live weight as a basis. In looking over this, we notice that a 1000-pound dairy cow producing 22 pounds of milk a day requires daily 29 pounds dry matter, 2.5 pounds protein, 13 pounds carbohydrates, 0.5 pound fat, with a nutritive ratio of $1: 5.7$.

A comparison of this standard with the ration fed, shows that our proposed ration is short of dry matter by 5.73 pounds; of protein, by 0.79 pound; of carbohydrates, by 0.70 pound; but has an excess of 0.11 pound fat. The nutritive ratio of $1: 8$ is also too wide.

The third step in computing the ration will be to correct or improve it so that it will compare more favorably with the required standard. If we can add some home-grown concentrate that is strong in protein, but lacking carbohydrates, it may balance things. It does not make so much difference about the amount of dry matter, so long as we do not greatly exceed that of the standard. Neither is it likely that the ration will contain too much fat. However, it is 
desirable to adjust the protein and carbohydrates fairly closely in amounts to those in the standard. We might use cotton-seed meal, or oil meal, as a trial, to balance up this ration; but to use a home-grown product that is getting more and more common, we will use soy beans, though they must be fed cracked or ground. Let us then add 3 pounds of the soy beans to the rest of the ration. Turning to the table of the composition of feeding stuffs, on page 387 , we find that:

\section{Soy Beans}

Dry iatter Protein Carbohydrates Fat $100 \mathrm{lbs}$. contain $\quad 88.3 \mathrm{lbs} . \quad 29.1 \mathrm{lbs} . \quad 23.3 \mathrm{lbs} . \quad 14.6 \mathrm{lbs}$. Then 3 lbs. contain 2.65 lbs. $0.57 \mathrm{lbs}, \quad 0.7 \mathrm{lbs}$. $0.44 \mathrm{lb}$.

Adding this to the total in the original ration, we have the following:

Dry matter Protein Carbohydrates Fat Total original .... 23.27 lbs. $1.71 \mathrm{lbs}, \quad 12.30 \mathrm{lbs} . \quad 0.61 \mathrm{lb}$. $3 \mathrm{lbs}$ soy beans ... $2.65 \mathrm{lbs} . \quad 0.87 \mathrm{lbs} . \quad 0.70 \mathrm{lbs} . \quad 0.44 \mathrm{lb}$.

Total....... 25.92 lbs. $\overline{2.58 \mathrm{lbs} .} \overline{13.00 \mathrm{lbs} .} \quad \overline{1.05 \mathrm{lb} .}$ The standard...... 29.00 lbs. $2.50 \mathrm{lbs} . \quad 13.00 \mathrm{lbs} . \quad 0.50 \mathrm{lb}$.

Excess or deficit $-3.08 \mathrm{lbs}$ +.08 lbs. Correct $+.55 \mathrm{lb}$.

Nutritive ratio, 1:5.9. Standard, 1:5.7.

This ration shows a shortage in dry matter of 3 pounds, a very slight inerease of protein, and quite an increase in fat. These differences, however, are not important. The nutritive ratio agrees fairly well with the standard. Therefore we may consider this ration properly calculated and corrected to suit the animal's needs.

The adjustment of rations to the standard is not usually difficult. An increase in dry matter and carbohydrates is easily secured with the hays or most of our common feed stuffs. If a ration needs most attention in the protein, then some concentrate such as soy beans, cotton-sced meal, linseed oil meal, or tankage may be selected. The cost of the 
feed is an important matter, and should be carefully considered. Some feeding stuffs, like cotton-seed meal, oil meal, or tankage, that are not common in some localities, are easily purchased and shipped in by freight, and may of ten be used with much advantage and profit. These are highclass concentrates, and are extensively purchased by feeders of stock in countries where but a comparatively small amount of feed is grown, as in England and Holland, for example.

The regulation of the ration to the animal's weight is not difficult. If this cow had weighed 750 pounds instead of 1000 , then the total amount of dry matter and of each nutrient would need to be decreased about one fourth, or 25 per cent. If the ration was for a cow weighing 1250 pounds, then this would require an increase in the ration of about one fourth. One does not change the proportions in the feeding combination. It is simply a proportionate increase or decrease in amount fed, to meet the needs of the animal.

Are the Wolff standards reliable? is a question quite likely to be asked. Years ago, when the German tables were first introduced to America, they were criticised by some of our students of feeding. Several persons showed by experiments that where animals were fod the maintenance rations proposed by Wolff, that they would gain in weight. Of course an animal should neither lose nor gain on such a ration. Professor Haecker of Minnesota, and other experimenters, showed that Wolff proposed to feed more dry matter and protein than was needed by the dairy cow, under certain conditions. Haecker also considered that dairy cows should be fed according to both the amount and quality of the milk. In general, investigations in America have shown that less protein is required for dairy animals than is given in the German standards. Probably two pounds of protein, or very 
slightly over, are required, as compared with $2 \frac{1}{2}$ recommended in the Wolff table. These standards, however, are a guide to intelligent feeding. One is not expected to measure out to each animal an exact amount of dry matter and nutrients to just agree with the standards, but rather to so combine the feeds that they will furnish the balanced ration reasonably well.

Other feeding standards than Wolff's have been proposed. Kellner, a noted German student of animal nutrition, has proposed a standard in which starch is the unit of value. Armsby, a leading American investigator, has offered a standard which is based on the energy or heat value of food referred to in the preceding chapter. He has prepared a table showing the values of certain fecds in protein and net digestible energy, expressing the energy value in therms. He has also prepared other tables showing what is required as a maintenance standard for horses, cattle, and sheep, and also for growing cattle and sheep. The important feature of the work of the more recent investigators is that they figure that each animal requires a certain amount of nutriment for maintenance, after making allowances for losses of energy in digestion and assimilation. They then add to the nutrients of maintenance enough more to meet the special body needs, to produce growth, milk, wool, or energy for external work. These changed views on standards have been made possible by the use of the digestion calorimeter in which animals as large as full-grown cattle are placed. With this apparatus, the experimenter can measure up the losses from the body through respiration and through heat and moisture from the body surface. Such information as this was not available at the time Wolff introduced his feeding standards. Thus far, but little practical application of the energy standard of value has been made by feeders. 
This subject, however, is being carefully studied, and later these standards, or revised ones, may come into general use.

\section{SOME RATION PROBLEMS}

1. Given a 1000-pound horse at medium work. He is fed 10 pounds oats, 10 pounds timothy hay, and 10 pounds ear corn a day. How does this agree with Wolff's standard?

2. A steer weighing 1500 pounds, nearly fattened, consumes daily 20 pounds clover hay, 18 pounds corn-and-cob meal, and 5 pounds cotton-seed meal. Is this satisfactory?

3. Make up a ration for a 500-pound brood sow, and figure out how it compares with the standard.

4. Feed 2 pounds alfalfa hay a day to $a_{1}$ fattening sheep weighing 100 pounds. How much and what kind of grain will you feed to adjust the ration to standard? 


\section{CHAPTER XXI}

\section{COARSE FEEDS AND THEIR VALUE}

The coarse feeds inelude the grasses and clovers of different kinds, the cereals (as forage), straws, silage, roots, rape, cabbage, or any similar feeds, whether green or dried as hay. Anything of a bulky nature, of which an animal must eat considerable to obtain much nutriment, is a coarse feed. In the dried form, like hay or corn stover, the western farmer has been accustomed to refer to them as fodder, or roughage. In some sections of our country, farmers have certain feeds that are more common than in other parts of the country. Farmers in the North, for example, look to red clover or timothy hay for standard roughage; in Alabama, cow pea hay or Japanese clover is common; while in Kansas and Colorado, alfalfa is a standard. Some plants, however, are more commonly grown than others, and so will receive special attention in a brief way in this chapter.

\section{PASTURES, GREEN GRASSES, AND HAYS}

The value of the grasses depends upon their development. When grass is young and very green, especially in spring, it contains a large percentage of water, and is greatly relished by stock. As it matures, the amount of protein and total nutriment increases. Usually we find the food constituents, cspecially protein, most digestible when the plant is in full bloom. After that period the stalk and leaves grow more woody and less nutritious; and if left to develop for long after blooming, neither the pasture nor the hay is eaten with the greatest relish. 
Kentucky blue grass, or June grass, is one of the most nutritious and best pasture grasses. It grows extensively in the United States east of the Mississippi, though sparsely in the Gulf states. No other grass is more relished for spring pasture by grazing animals. The roots spread out near the surface of the ground and form a beautiful sod. In moist weather and under fair conditions, the grass furnishes an abundance of fine leaves, supplying splendid pasture. During the summer, many pastures dry up and look as though

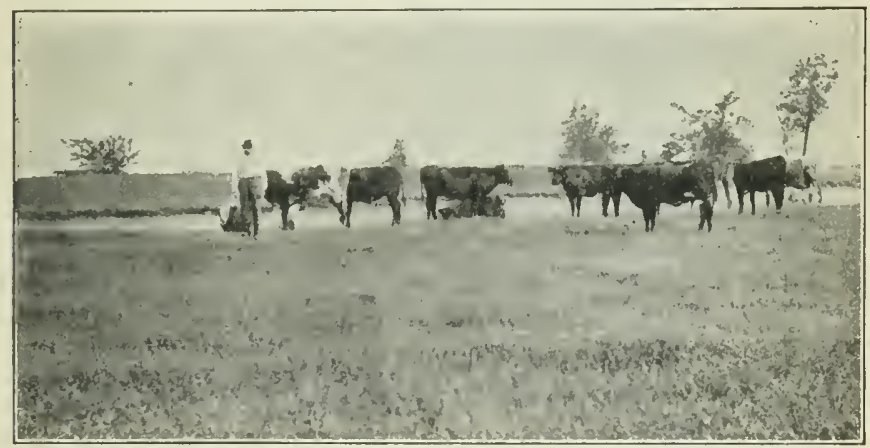

Fig. 153. On an Ohio blue grass pasture. Photograph by the author.

dead, but fall rains revive them, and they again become green and vigorous. In some sections, stock is pastured on the dead blue grass of winter, not much other feed being given, and with very good satisfaction. Kentucky blue grass is not usually valued for hay, but is known universally as a valuable pasture grass.

Timothy is a standard grass eommonly grown on the heavier soils of the North. It is frequently used for pasture, and makes a highly valued hay for horses." As a pasture grass, timothy is not the best. It does not stand trampling 
as well as some others, having small bulbs at the ground, with fine roots just beneath them, which are injured by heavy pasturing. This grass is generally somewhat coarse, but if it is thickly seeded, more plants grow to the acre, and as a result they are finer and more palatable. Timothy cut and cured immediately after the pollen falls from the blossom makes the best hay. Under usual conditions, this is an excellent hay for horses, but not so well suited to cattle and

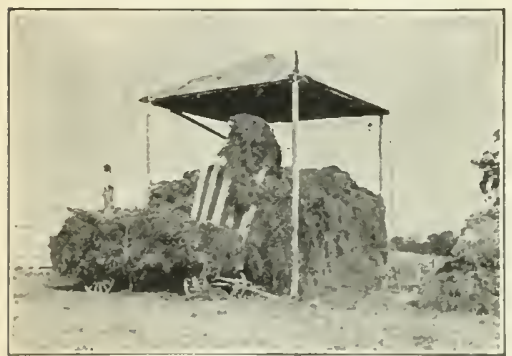

Fig. 154. A good cover for the stack of hay. Photograph by courtesy Prof. A. G. MeCall. sheep. Care should be taken to see that timothy hay is bright and free from dust.

Red top is a fine grass in appearance, and makes an excellent pasture. It is quite common in certain sections North and South, but is not generally abundant in the cooler grass-growing sections, probably doing better on the damper lowlands than elsewhere. It makes a very palatable and nutritious hay.

Orchard grass is common in some sections in the northeastern parts of the United States. It grows in tussocks, or bunches, so that the turf from this plant is somewhat uneven; hence is not liked so well as some other grasses for pasture. It starts up early in spring, and has a strong, rather coarse growth, with hardly as smooth a stem as timothy. It is not quite as nutritious as timothy, ranking just below it. It may be grown to advantage with red clover, and often is, in the Middle West. It is hest suited for horses and eattle, though should be cut as hay before getting very ripe. 
Millet is grown in a number of varieties. Hungarian grass is the smallest form, and reaches a height usually of about two feet, with a single, small, bristly head. This makes very fair hay. German Millet is somewhat larger and coarser than Hungarian, and has a larger head, though of the same type. Both of these millets may be sown in early summer, and often they make a very rapid growth and furnish an abundant hay crop in a short season. Millets are not generally used in pastures. When heavily seeded they make very good hay for cattle and sheep. Caution should be used in feeding this hay to horses, as it is thought by some to cause kidney trouble if fed very heavily. The millets may be grown over much of the country.

Brome grass has been cultivated some in the Northwest, where it has been used as pasture and for hay. At the North Dakota station it is used for permanent pasture, and is ranked as much richer in protein than timothy. It also yields about the same quantity of feed per acre as timothy.

Bermuda grass in the South is a standard pasture. This plant grows a perfect network of roots near the surface, and covers the ground as with a mat. It is a very nutritious pasture plant, and has a most valuable place in Southern agriculture. It will stand heavy pasturing, and may be used from March to November. If grown on rich soil, very heavy cuttings of hay may be expected. Bermuda grass contains over 6 per cent protein and about 45 per cent carbohydrates, excelling in protein any other common grass.

Mixed grasses are frequently sown for pasture in the Northern states, timothy, red top, orehard grass, and clover forming the usual combination. Prairie grass is usually a mixture, and somewhat resembles timothy in feeding value. 


\section{THE CEREALS AS FORAGE}

Indian corn is perhaps the most common plant grown on the American continent. Except in the arid lands, it thrives from the Atlantic to the Pacific, and from the Gulf to Caulada. It is the universal crop of the Mississippi Valley, and furnishes more food from an acre of ground than any other common crop. It is keenly relished by horses, cattle, and sheep, both in the green state and as dried roughage. No other plant in summer furnishes so much succulent feed as Indian corn. Grown somewhat thickly, the stalks are finer than common,

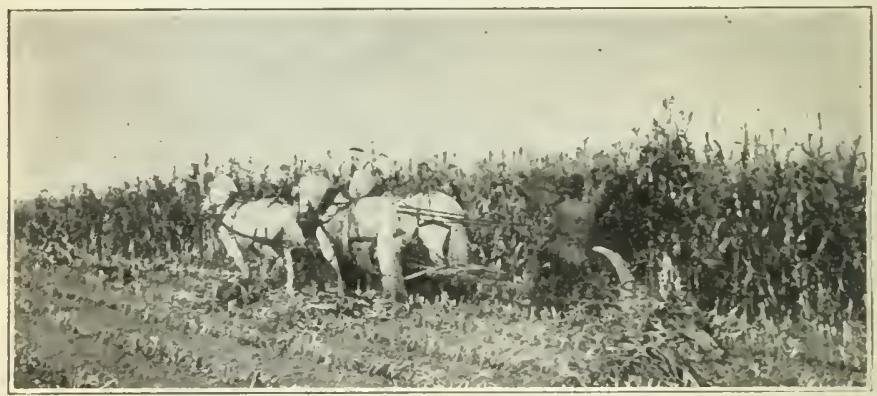

Fig. 155. Cutting the corn crop with a corn harvester, which tics the corn in bundles. Photograph by courtesy Minn. Agr. Exp. Station.

and give a large vield of either green fodder or dried forage that is quite completely eaten by eattle and horses. In the North, corn produces a smaller plant than in the South, and gives a smaller yield of forage. Very large, heary stalks, such as are frequently sern in the com belt, are not so desirable for feeding as those of more moderate size. About one-third of the digestible food is found in the stalk, and twothirds in the ear. The complete cured plant and ear is commonly known as corn fodder, and after the ear is remored it is called corn stover. The dry stover, with the help of a 
little grain, is valuable for roughing stock through the winter, if much fattening is not desired. It is a bulky feed, and should not be fed heavily to animals from which much is expected. The plant contains the largest amount of nutriment when the kernels on the ear are beginning to glaze or harden, but it may be cut for feeding at any time from the appearance of the silk to final ripening. Fodder left out in the shock during the winter is injured more or less in feeding value, losing in nutriment through mould and weathering.

Oats do best in the cooler sections of the North, but socalled winter oats do well in the South. This crop may be pastured or may be cut and fed green when of sufficient maturity. In New England many farmers grow oats to cut and cure as hay when the grain is in the milk. Oat straw is one of the best, both in nutritive value and in being relished by stock. A combination of oats and Canada field peas, from equal amounts of seed sowed early in spring, makes a very desirable green crop for feeding in June and July.

Rye has been much used both as fall and spring pasture. It mats up into a thick growth, and can be grazed with advantage to the grain yield if not pastured too long or too heavily, or it may be cut green and fed in the stable or feed lot. Many people grow rye and turn stock on it to harvest it entirely. Hogs are frequently tumed in, and they consume both stalk and grain. Dairy cattle should not be fed rye, except soon after milking, otherwise a strong and unpleasant odor in the plant will be likely to give a bad flavor to the milk. Rye straw is a very poor feed, having less than one per cent protein and a great deal of fiber.

Wheat and barley may be used after the same manner as rye, and have much the same value, though they are not 
pastured as advantageously as the rye. Barley makes a nice soft hay, and is relished by stock of all kinds. Of the cereal straws, barley ranks close to oats as one of the best.

\section{THE LEGUMES FOR FORAGE AND HAY}

Legumes, which include the clovers, alfalfa, beans, peas, etc., grow easily over much of the United States. They are valuable chiefly because of the large percentage of protein they contain, and from the fact that they are highly relished by live stock. The lime in the legumes is also a valuable feature of these plants, for it is needed in building up the animal frame. The legumes have an extensive root development, and have the power of fixing the nitrogen of the air in the soil, through the agency of a kind of bacteria that are found especially in knots or nodules located on the roots. These nodules are rich in nitrogen, and where legumes are grown, the land is increased in fertility and improved in texture.

Red Clover is extremely common in the Mississippi Valley. One hundred pounds of the dried hay contain about 7 pounds of digestible protein and 38 of carbohydrates. As a feed for cattle and sheep, it is considered excellent. As a pasture it ranks high; and in the corn belt, a combination of clover pasture in the late summer and fall, supplemented with ear corn, is a favorite ration for hogs. Brood sows and sheep do well on clover pasture. A large crop of green feed may be cut from a good stand of clover during the season, and this makes splendid feed for all kinds of farm stock. At the Wisconsin station, as much as 26 tons of green feed were obtained in 3 cuttings from an acre of red elover. If to be used for hay, red elover should be eut when the blossoms are in full development, at which time it contains the most nutriment. Clover should be 
cured carefully and protected from the wet as much as possible after cutting. When clover hay is woll cured and reasonably free from dust, it may be fed to horses with advantage.

Alfalfa is rapidly becoming a very popular plant in America. In the irrigated sections of the West it has long been a leading crop. In recent years, its cultivation has been greatly extended, so that now it is grown with success over much of the United States, north and south, and also

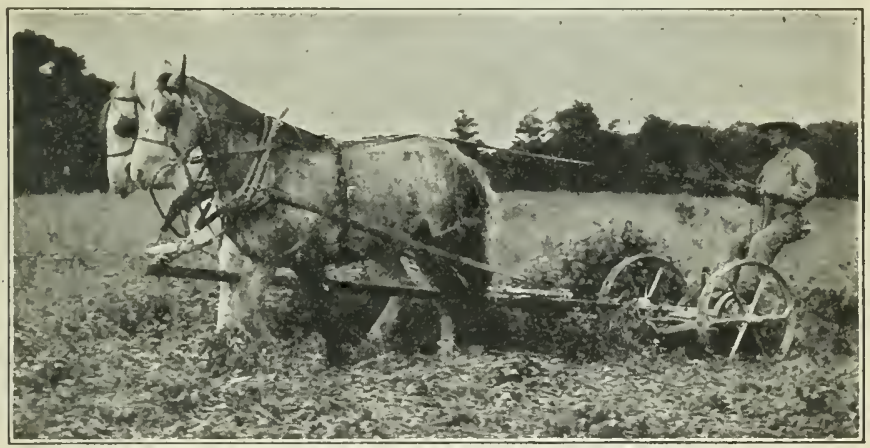

Fig. 156. In a field of red clover in Indiana. Photograph by the author.

in some parts of Canada. From two to five crops a year may be harvested. At the New Jersey experiment station, 5 cuttings yielded $26 \frac{1}{2}$ tons of green forage, equivalent to almost 6 tons of dry matter per acre. Alfalfa is a plant that is rich in protein, and the dried hay is often compared with wheat bran in composition and feeding value. The fact is, alfalfa is so close to bran in protein and carbohydrate content that in some sections of the West it is ground and fed in a meal-like form. Large quantities of special feed stuffs are made of this alfalfa meal, and are sold in nearly all parts 
of the country. Alfalfa makes fine pasturage, especially for sheep and hogs, but it is not generally used for this purpose. It is undesirable to pasture it much, as heavy trampling injures the crowns of the roots. Neither should it be pastured very closely. A combination of alfalfa pasture and corn makes a splendid ration. When sheep or hogs are turned on this pasture, they should first have a good fill of hay, and should be kept constantly on the green feed from then on, by which method, bloat will be prevented. When made into hay, the plants should be cut at about the time

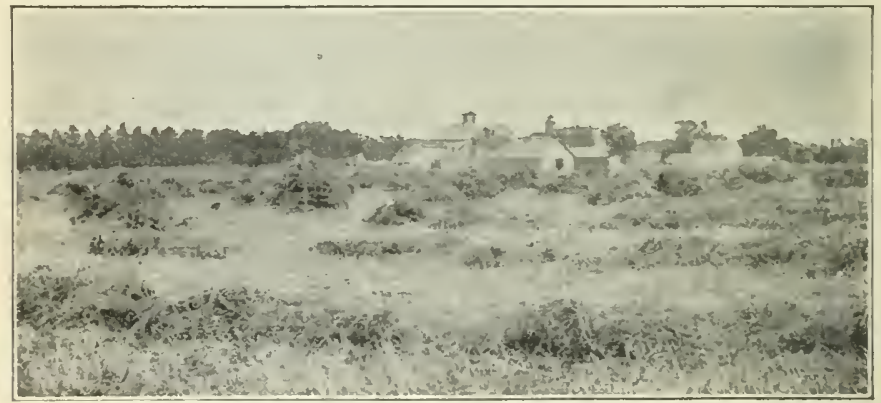

Fig. 157. A field of alfalfa hay at Ohio State University. Photograph by the author.

new shoots begin to appear about the erown of the root, and when the burls are beginning to open. The plant should be cured so as to hold as mueh bright green leaf as possible. As hay, this plant is unsurpassed. It is suited to horses, eattle, sheep, and hogs. All these animals like it, and to well on it. Corn is one of the best feeds to give with it. In the West, large numbers of sheep are fattrned on corn and alfalfa. Brood sows do woll on alfalfa hay anel a little corn. This plant is one of the most valuable fecds used today on the stock farm. 
The soy bean thrives over a wide extent of territory, and is meeting with considerable favor as a forage crop, and also for its seed. This plant is rich in protein, and combines unusually well with corn. Hogs have done well when pastured upon soy beans. It is also grown to some extent with corn, for the purpose of harvesting the two plants as one crop for the silo. Under some conditions this combination gives very nearly a balanced ration.

The cow pea is mostly grown in the South. It is planted to some extent in the middle Mississippi Valley, although it does not usually ripen seed in the North. It produces a great amount of forage, which is much valued for grazing and for plowing under. The peas are rich in

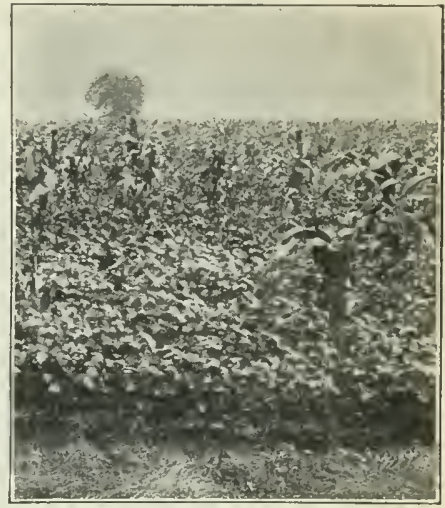

Fig. 15s. A field of Indian corn and soy beans at Ohio State University. Photograph by courtesy Prof. A. G. MICCall. protein, and the yield is very satisfactory. This is one of the most valuable plants grown in the South, for grazing, for hay, and for seed. The hay may be used to some extent as a substitute for bran.

Canada field peas in the northern part of the country, make a valuable green crop for soiling, especially if planted with oats early in spring. A seeding of oats, followed immediately by one of peas on the same land, using about one and a-half bushel of each seed to the acre, gives one of the very best green feeds for early and middle summer use. This combination may be safely fed to farm animals generally, and 
they all like it. If desired, it can easily be cured into a very good grade of hay.

\section{SILAGE}

Silage is a feed more or less green and succulent, preserved in what is called a silo. Green feed is cut and stored in the silo, where it goes through a process of fermentation, with slight loss of its protein and carbohydrates. Under fair management this loss need not be over ten per cent.

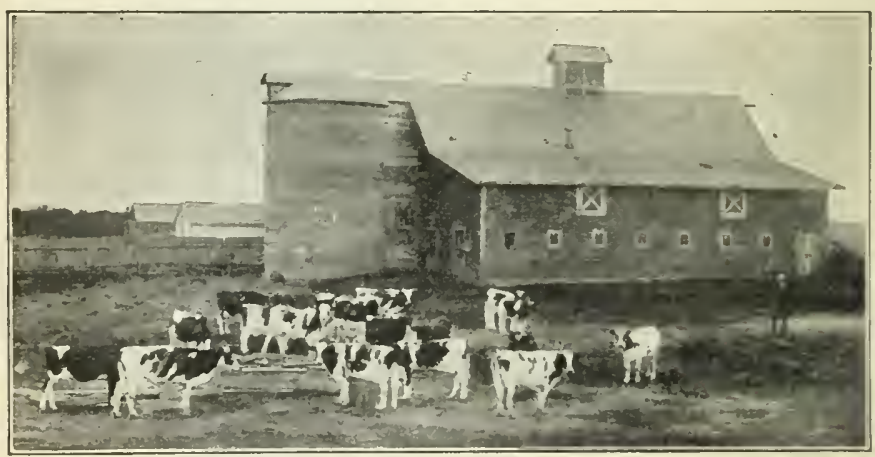

Fig. 159. A cement silo on a dairy farm. Photograph by courtesy of The Farmer.

The silo is one of the most valuable things on the stoek farm, for in it feed can be stored more economically than in any other way.

Silage may be made from a variety of plants, but at the present time corn is used nearly altogether. That is because it combines the largest yield of the most easily stored forage of all crops generally relished hy stock. Sorghum, elover, cow peas, soy beans, and alfalfa are sometimes used. With the exception of sorghum, these plants are not always stored in the silo with satisfaction, as they may heat bally and sus- 
tain considerable loss in food value, unless well handled. For this reason, corn silage only will be discussed here. Sorghum and kaffir corn may be preserved in the silo equally well with corn.

The chief value of silage lies in the fact that it enables the stockman to give his eattle and sheep, especially, a succulent feed during the months of the year when the pastures are dead and no green feed is obtainable. If one has plenty of silage, then he is quite independent of summer drouth. In fact, many owners of dairy cattle feed silage the year round. Because of its tender, succulent nature and the convenience of handling, it is well adapted to all seasons.

The corn crop is usually harvested when the kernels are turning into the glaze. It then is run through a forage cutter and cut into pieces about half an inch long. In this condition it is spread about in the silo and allowed to settle. As usually made, it contains about $1 \frac{1}{2}$ per cent protein. The dry matter in silage is worth no more than that in corn fodder, chemically considered, but cattle especially seem to respond to this feed, with increase of milk flow and a better condition of body, than when on dry fodder. Many feeding experiments have shown that corn silage is most desirable for dairy cows, and very favorable reports are being made on its use in beef production. It is well suited to sheep. Horses will do well on it when fed with moderation. For hogs, however, silage is too bulky and unsatisfactory and is rarely fed to them, and then with little benefit in most cases. In general, hay and some grain should be fed with silage. For cattle, from 25 to 35 pounds a day is a common ration while for sheep from 3 to 5 pounds daily is ample.

Rape is a plant that belongs to the same family as the turnip and radish, and is grown for its suceulent leaves. It is used exclusively for pasturage for sheep and hogs and is 
well suited to the cooler sections of the country or to cool seasons. In Canada and the northern United States rape is an extremely popular pasture plant among sheep breeders. Three or four pounds of seed per acre will do for a seeding, and stock may be turned on the field after the leaves have become large and succulent. Rape will stand considerable frost without damage. At the Michigan station, 15 acres of rape pastured 128 lambs for $71 / 2$ weeks, during which time they gained 2890 pounds. From this trial it was established that one acre of rape pastured nine lambs seren wceks, producing 203 pounds of increase. For sheep and hogs, rape furnishes a most valuable late summer and fall pasture. It may also be sown in early spring, so that we may secure the pasture during the entire growing season.

\section{ROOT CROPS}

Although all farm animals relish roots, these crops cannot usually be grown with profit in America, on account of the high cost of labor. In Canada and northern United States, roots may be grown with great success on fertile soils, but south of latitude 40 , as a rule they do not yield so well.

The mangold or mangel-wurzel, a large, coarse beet, is the most easily and cheaply grown of the roots used for stock feeding. The roots consist of about 90 per cent water, and of the dry matter, only 1 per cent or even less is protein. A yield of 10 tons per acre is not uncommon. The chicf virtue of the roots is that they are succulent and are most palatable, and keep the digestive organs of the animal in a healthy, open condition. They are usually fed after being run through a pulping or slieing machine, which puts the root in nice shape for fecling. Many feeders in England and Scotland, where roots are extensively used, mix the 
sliced root with chaffed hay or straw and grain, which makes a fine ration. One may feed cattle as high as 100 pounds of roots a day, but as a rule about 40 or 50 pounds is best. Sheep do especially well on roots, and in Great Britain and Canada they are commonly fed to these animals, from 5 to 7 pounds per diay.

Carrots are slightly more nutritious than mangels, but are more difficult to grow, and do not yield so large a crop. They are raised especially for horses, and are fed to them with more success than other roots.

Swede turnips, flat turnips, and rutabagas are all good for stock and have much the same wholesome effect as mangels and carrots.

\section{CAN YOU TELL}

1. Why the feeding value of a grass depends on its stage of development?

2. Why timothy is a standard grass for horses?

3. Why, in the opinion of some, millet should be fed with caution?

4. Where and why Bermuda grass is popular?

5. Why Indian corn is so valuable to the farmer?

6. How the legumes add to soil fertility?

7. Something about alfalfa?

8. Wherein lies the special value of silage?

9. Why roots are not grown more for stock in America?

10. How many pounds of roots a day should be fed the different kinds of farm animals?

\section{SUGGESTIONS}

11. Bring in small samples of different kinds of roughage used on the farm on which you live.

12. Bring to the class about a half-pound sample of average hay such as you are commonly using on the farm. Compare with the other class samples. 
13. Find the nitrogen-carrying nodules on legume roots.

14. Feed some green rye to a milch cow three hours before milking. How did this affect the milk?

15. Learn who puts up the best hay in your neighborhood, study his methods and report on them.

16. How many silos are there in your township or section, and to what animals is the silage fed? 


\section{CHAPTER XXII}

\section{CONCENTRATED FEEDS AND THEIR VALUE}

A concentrated feeding stuff is, as one would naturally suppose, just the opposite of roughage. The two most common forms are seen in the grains of cereals and some other agricultural plants, and in the by-products of mills, where the cereals are converted into flour, breakfast foods, starch, etc. There are some other concentrates, that are products of such large manufacturing inclustries as the linseed and cotton-seed oil mills, and the packing houses. These are all called concentrates, because as a rule they lack in coarse, fibrous structure, and contain larger percentages of protein and starchy matter than do forage plants. For example, the grain of corn is a concentrate, one hundred pounds of which contains fully three times as much digestible protein and twice as much digestible carbohydrates as are found in corn fockder. Using another illustration, gluten feed, which is made as a by-product in the manufacturing of starch from corn, contains three times as much protein as does the same weight of corn.

The cost of concentrated feeds is always much greater than that of roughages. In fact, the cost of most feeds sold on the market increases as the amount of protein in them increases. Feeds like cotton-seed meal and tankage, containing large amounts of this nutrient, are very high-priced, although that does not mean that they are expensive feeds to use. Somctimes the price of a certain concentrate is low on account of a glutted market, or high because the supply is exhausted. If, for example, the flax-seed crop of Russia and America is very poor, then linseed oil meal is apt to be high- 
priced, and perhaps would cost more than it is really worth. There is no special rule, however, about that matter, and sometimes business combinations control the prices of such feeds, so that one must pay without regard to the actual supply on the market. The following concentrates are quite commonly used, and are those which one should know something about.

\section{CEREALS AND THEIR BY-PRODUCTS}

Indian corn is our most common grain. It is a food rich in carbohydrates and fat, and is especially valued for fattening animals. It is often called a heating food, on account of its heat or energy value. It is greatly relished by all farm animals, and may be fed on the ear, shelled, or milled into pure meal, or the entire ear may be ground into what we call corn-and-cob meal. While corn is rich in fattening material, it lacks in ash, or mineral matter, so that when fed alone it furnishes a rather one-sided ration. Except during the last part of the fattening period, it should be fed along with some feed rich in protein and ash, such as bran, middlings, etc.

There are different races of corn. In the more northern parts of the country, as in New England, a small to mediumsized plant, with a somewhat slender ear, covered with hard, flinty kemels, is grown. This is called flint corn. Over most of the country a larger plant, with thicker ears, covered with longer kerncls, dented at the outer end, is grown. This is known as dent corn, and makes up most of the corn crop of the United States. Besicles these two, we have sugar, or sweet corn, which has a rough-surfaced ear that may be very small or of medium size, covered with kemels that when dry are somewhat shrivelled and tough. This sweet corn contains some glucose sugar, which accounts for the pleasant taste of the grain. 
Corn meal is the ground grain without the cob. The usual run of such meal on the farm is rather coarse and is often eracked or crushed rather than fincly ground. In some sections, the farmer calls it "corn chop." Ordinarily, it does not pay to grind the grain, although it is more completely digested than is the whole kernel, but the expense of grinding usually offsets any advantage, except for some special purpose.

Corn-and-cob meal is the kernel and cob ground up together. If the cob is not too coarse, such feed is excellent for eattle and sheep. Feeding experiments have shown that 100 pounds of corn-and-cob meal fed to these animals will give returns equal to 100 pounds of pure corn meal. The reason given for this is that the ground cob makes the meal more porous, allowing the juices of the stomach in digesting the food, to mix more easily with the corn and porous cob meal, than with the pure meal, which is inclined to become heavy and soggy. This feed is not good for hogs, unless ground very fine, as it contains too much woody fiber. It is better for cattle.

Gluten feed is a product of factories where starch is made from corn. It consists of what is left of the grain after the starch and germ have been removed, and is quite rich in digestible protein, containing about 20 per cent. Cattle and sheep are fond of it, and it is a mill product of much value in balancing a ration for these animals. Gluten meal, another product of the starch factory, richer in protein than gluten feed, was formerly sold separately. At present it is usually ground in with the gluten feed.

Hominy feed is a by-product of the hominy mill. It resembles a fine whitish corn meal when-male from white corn, and consists of the hulls and other parts of the corn grain ground up together. Its feeding value is quite the 
same as corn meal, and it is excellent for cattle, sheep, and hogs, all eating it with a relish.

Wheat is not usually fed to animals, unless it is very low in price. It becomes somewhat pasty when ground in the mouth, as everyone knows who has lived in a wheat country. It contains about 10 per cent digestible protein, and belongs in the class of feeds fairly rich in this substance. All animals are fond of wheat, but it should be erushed or eracked before feeding to horses, cattle, or hogs. This is not necessary with sheep. Wheat tends to make animals muscular or lean and hence its feeding value is greatly improved by the addition of an equal amount of corn.

Wheat bran is the outer covering of the kernel. In the big flour mills, the kernel is crushed to obtain the flour, and the thin outer fibrous covering is removed as bran. This contains about 12 per cent protein, and is a standard concentrate for feeding horses, cattle, and sheep. We say that bran is a laxative, and keeps the digestive system cool and open, a very necessary thing with farm animals. Stockmen have always regarded bran as especially valuable. It has recently been found by chemists to contain an acid substance called phytin, which causes beneficial effects on the digestion. Wheat bran is well suited to mix with corn or oats, or may be fed alone to stock. Many horsemen feed it in the form of a thick, wet, warm slop, called "bran mash." Bran is even more of a muscle and bone making food than wheat, and most stuclents of feeding use it for young, growing animals. There are brans made from spring wheat, such as is grown in the Northwest, and from winter wheat. There is not much difference between them, but the bran from winter wheat usually contains somewhat more flour than that from spring wheat. 
Wheat middlings and shorts are also by-products from flour mills. Middlings are much finer than shorts, and contain more flour. Shorts is sometimes bran re-ground, hence is finer than bran. Bran, middlings, and shorts are much alike in digestible protein content, containing around 12 per cent. Middlings and shorts contain rather more carbohydrates than does bran. Middlings are especially valuable as a hog feed, being used with corn or corn meal. Good results have been secured by feeding hogs a mixture of half corn meal and half middlings. On the market, middlings usually sell for about two dollars more a ton than bran. If one can buy bran or middlings, he will not need shorts, which are too fine for bran and too coarse for middlings.

Wheat screenings usually consist of shrunken, broken grains of wheat, mixed with weed seeds, pieces of straw, etc. The value of screenings depends upon the amount of grain in it. It has been very extensively fed to fattening sheep in America, especially in the Northwest, near the flour mills. Sheep do well on screenings, and if one can buy at a cheap enough price, it is a good feed to use.

Oats are a standard feed for farm animals in all agricultural countries. They contain about $101 / 2$ per cent digestible protein, as compared with about $81 / 2$ in wheat, but have less carbohydrates and more fat than the wheat. It has often been thought that oats contained some substance that gave life and snap to animals beyond that furnished by any other grain, but chemists have not been able to find this mystical something. Still, it is generally agreed that oats do produce a most excellent effect on the horse, far better than any other grain. Some oats are more chaffy than others. Northern grown oats are plumper and weigh more than Southern oats. In fact, oats do better in the cooler sections of our country, and yield far larger crops. For 
horses no other food is so widely used in America or Europe. It is not likely to cause indigestion, and is a safe feed. It is best suited to cattle and hogs when crushed or ground, while sheep will do equally well on it in any form. For young, growing animals it is one of the best feeds we have; for like bran, it helps to build up a strong, muscular frame. Often oats are very expensive, and their purchase should depend considerably on the cost and the purpose for which they are intended.

Oat hulls are very poor as a feed stuff, for they contain but little nutriment, and are too largely fiber. They are frequently mixed with commercial feed stuffs to act as a "filler."

Barley is a very hard small grain, that as commonly grown is covered with a strong husk. It is rich in carbohydrates, and has slightly more protein than corn. It is not commonly fed to farm animals in America, but is very popular in northern Europe. Horses will do well on barley, while barley meal as a feed for swine ranks very high in Canada and Europe. Experiments have shown that pigs fed barley make a superior quality of bacon. It should be crushed or ground before feeding.

Brewers' grains are a by-product in the manufacture of beer. Barley is put through a process of sprouting, after which it is dried and the sprouts rubbed off. The remaining mass of barley kernels is malted barley. This is then soaked in tanks, and the sugar or malt, formed in the kernel by the sprouting, is extraeted, and is fermented to make lager beer. What is left is wet brewers' grains. These in the wet form contain about 75 per cent water and 5 per cent digestible protein. They are relished by cattle, and are much fed in the vieinity of cities where brewerics are located. In summer they become sour and putricl, unless eaten a few days after making. Dried brewers' grains are made by removing 
the moisture in big steel drums. This leaves a dry grain, with about 20 per cent digestible protein and 30 per cent carbohydrates, which makes a valuable feed for horses, cattle, and sheep. It has been used with success as a substitute for oats as a feed for horses, when oats were high in price.

Rye is quite similar to wheat in composition. It makes a good feed for the same purposes that wheat is used. It has a somewhat stronger flavor than other grains, and when fed to dairy eows, tends to give an objectionable taste to milk. If fed, it should be given right after milking.

Linseed oil meal is the product of flax seed. This seed contains about 30 per cent oil. The manufacturers of linseed oil grind the seed, and extract the oil by pressure, leaving long, brown, board-like cakes, as a by-product. This is broken up, or ground, and fed as linseed oil eake or linseed oil meal. It contains about 30 per cent digestible protein, and slightly more of earbohydrates. All farm animals are most fond of this product, and it is used to some extent by many feeders. It softens the skin of animals and gives a silky lustre to the hair. It is often used in so-called condition powders, to make up much of the bulk of them. It should form from one-tenth to one-fifth of the ration, according as the need exists for a highly concentrated feed to balance the ration.

Cotton-seed meal is a by-product of the cotton-seed oil mills. About one-fifth of the seed is oil. The usual custom is to remove the hard eovering or hull of the seed, and then press a dark brownish oil from the meats, which, when refined, becomes an attractive golden yellow. The by-product remains as long, ycllow, board-like eakes, that contain almost 40 per cent digestible protein. It is one-gf the most concentrated and valuable feerls that we have. Small particles of hulls are to be found in the cake, and the greater the 
amount of hulls the poorer the grade in protein of the cake. It is best suited to cattle above ealf age, and for sheep. Combined with corn silage or stover, and with some shelled or ear corn, it makes an excellent balanced ration. Cotton-seed meal is not a safe feed for pigs or calves, as it has a poisonous effect, which may result in serious sickness and death. Cotton-seed meal is often one of the most economical protein foods that the cattle feeder can buy, considering the character of the nutriment it contains. It is fed to some extent in the South, along with the hulls, which largely consist of woody fiber, and fair gains in steer feeding have come from this combination. Milk from cows fecl cotton-seed meal produces a harder butter than when corn is used. The fat of steers that have been fed cotton-seed meal is also harder than that of steers fed corn meal. One can easily see that in warm sections of the country, as a result of the use of this feed, butter will ship better than it might if some other feed were used.

Distillers' grains are a product of the manufacture of alcoholic liquor, for which rye, corn, barley, and sometimes oats, are used. The grain is mashed in water, and the starch is changed into sugar, and later into alcohol through the influence of yeast. The mashed grain left is very watery; but if the water is removed by heat, a dried, brown, ehaffy product, rich in protein and fat, results. This is known under various names as dried distillers' grains, Ajax flakes, Atlas meal, Biles' grains, etc. Crains male from rye are inferior to those from corn. There is quite a difference in the protein values of these grains. They are especially popular with feeders of dairy cattle in making up a mixed grain ration. They have a strong odor that reminds one of the smell of hops, and some animals dislike it on account of this peculiar smell. As yet this feed has been but little fed in America, except to eattle. 
Tankage or meat meal is a product of the beef packing house. It is made from inferior pieces of meat and the trimmings, and from diseased carcasses. This meat is dried, and sterilized in air-tight tanks, and is then ground to a meal. It is very rich in protein, containing usually from 50 to 60 per cent, and 11 or 12 per cent fat. It is especially relished by hogs, and since 1900 has been much used in the West along with corn to balance up the ration. A mixture of one part tankage and 6 to 10 of corn gives excellent results in hog feeding. While this feed is high-priced, it is no doubt one

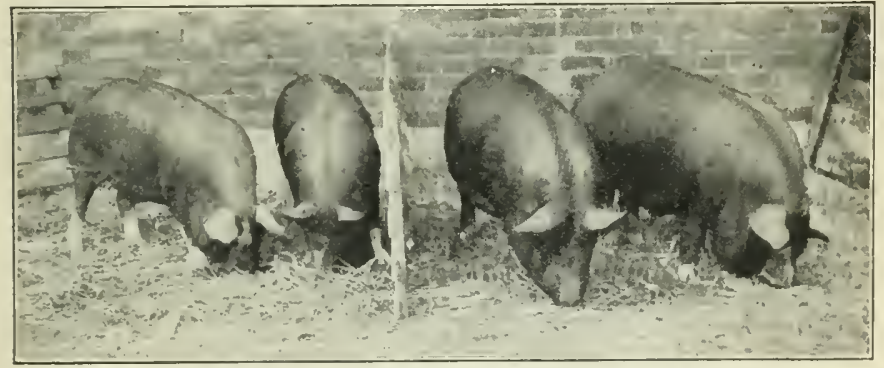

Fig. 160. Two lots of hogs fed at the Ohio Experiment Station. The smaller were fed corn alone in dry lot, and the others corn and tankage. Photograph by courtesy Ohio Agricultural Experiment Station.

of the most important additions to the rations of swine. The glossy coat of hair and hearty appetite of the tankage-fed hog are evidences of the value of this feed.

Milk is not strictly a concentrated food, but will be briefly referred to here. As drawn from the cow it contains about $871 / 2$ per cent water and $12 \frac{1}{2}$ per cent solid material. Of the solids, about $31 / 2$ to 4 per cent is usually fat and 4 to 5 per cent milk sugar. Milk is a most important food for all young animals during the earlier stages of growth. If new milk is fed, the young animals lay on flesh easily, and may 
take on a strong, muscular development. If the fat is taken from the milk, and skim milk is fed, a good frame may develop, but the animal will not look so well fed, the skin will not be so mellow, nor the hair so glossy. Pigs of any age will do well on a combination of milk and a grain rich in carbohydrates, which ration makes a very high-class pork. Buttermilk has much the same feeding value as skim milk, there being almost no fat in either. One should be careful to feed only clean milk, produced under healthful conditions. One should not feed skim milk from a creamery, unless it is first pasteurized, so that disease germs may be more or less completely destroyed.

\section{SOME CONCENTRATED QUESTIONS}

1. What are concentrates?

2. Why is corn so valuable?

3. Which is better for cattle,-corn meal or corn-and-cob meal? Why?

4. What special value has bran?

5. How do oats rank as feed for horses?

6. How are brewers' grains made?

7. Why recommend linseed oil meal?

8. What can you say about cotton-seed meal?

9. Why feed tankage?

10. What is the average composition of inilk?

\section{HINTS AND SUGGESTIONS}

11. Collect samples of concentrates fed in your neighborhood, and label with name, composition, and price.

12. Make up a sample ration, specifying on a card,-

(a) Pounls of each concentrate used.

(b) Cost of each concentrate.

(c) Nutritive ratio.

(1) Kind of stork for which prepared.

13. Learn what your ueighbors are feeding for concentrates, cost and how used. Can you suggest improvements?

14. Who feeds tankage, under what eomlitions, and with what results? 


\section{CHAPTER XXIII \\ THE CARE OF FARM ANIMALS}

The intelligent care of farm animals is the key to successful management and profitable results. This includes dealing with all sorts of conditions and problems, such as the practical stockman repeatedly meets with; injuries, sickness, and disease and methods of treatment. It is not desirable to discuss these in detail. There are, however, various important things connected with the care of animals that may fittingly be brought to the attention of the student and stockman.

Personal attention to the care of animals on the part of the owner or responsible manager, is highly important. Too many men leave the care of the stock to hired help who are often indifferent or careless. This always results unsatisfactorily. That kind of management often results in over or under feeding, losses from disease or injury that might have been prevented, poor physical condition of the stock, etc. One of the most successful handlers of cattle in America, a man with an international reputation, gives a most careful personal supervision to his animals, from early morning until night. In his annual sales the physical condition of his animals and the ease with which they are handled cause much favorable comment. This is very largely due to the personal attention he gives his cattle from day to day.

The feeding and watering of animals at regular periods when not on pasture, is of the first importance. It is customary to feed most kinds of stock twice-each day, morning and evening. Horses, however, are usually fed three times. 
A common custom is to feed grain and roughage to cattle morning and evening, with roughage at noon. The more painstaking, thoughtful feeders often feed more than twice, being careful as to the amount fed. A general policy should be followed of feeding as much as an animal will eat up clean, with good appetite, and the hunger then satisfied. The hours of feeding depend upon special conditions. Many persons begin feeding about 5 A. . ., and give the evening feed about twelve hours later. No rule, however, can be made on this point. It is a good plan to have water avail-

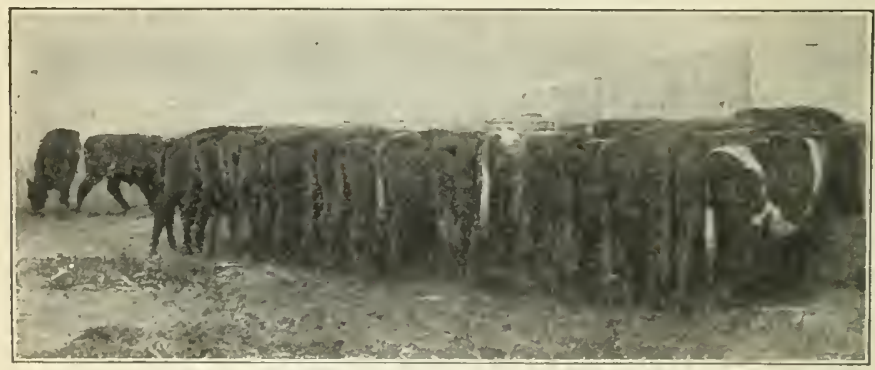

Fig. 161. Stcers eating roughage at the Ohio Station. Photograph by courtesy Ohio Agricultural Experiment Station.

able to stock, of which they can drink as often as desired. Horses are usually watered either before or after feeding. three times a day. The frequeney of watering will depend on the weather. Cattle, sheep, and hogs should be watered twice daily in the cooler weather, and in summer it is well to have available in stall or yard plenty of water in pail or trough.

The grooming of live stock becomes almost necessary under the more restricted conditions of stabling. Horses and cattle kept in stable and exposed to dirt and manure, become more or less filthy. Dust and dirt on the skin tend 
to close up the pores, which to a certain extent affects the disposition and health of the animal. As a matter of personal pride the high-class owner of stock desires to have his animals look clean. If he is a good horseman, he knows that a well-groomed horse looks and feels better than one that is not clean. One of the most unpleasant sights to be seen in winter and spring in many barns is the cattle with thighs and flanks covered with a hard coat of manure, that does not disappear until the hair is shed. This of course means that no grooming is done or little effort made to keep the stock clean. It is surprising what excellent results will come from the use of a brush and curry comb for a very short time, even a minute a day per head. Grooming is not always practicable; neither is it necessary, as for example, in the West in the open feed lot, where cattle that have never been even halter broken are cared for in large numbers by a few nien.

The sanitation of the stable, or the health conditions about live stock, are receiving much attention these days. Men can no longer sell milk in most towns and cities unless it comes from stables that are approved as sanitary by milk inspectors, representing the consumers' interests. This means that the stables must be properly furnished with fresh air and that the buildings and yards must be kept clean and free from filth. Where the stable is sanitary, it is provided with a reasonable amount of light and pure air, and the walls are whitewashed or are kept clean and attractive by some other good method. One of the best methods for making the stable interior sweet and clean at least expense is to spray whitewash on the ceilings and walls once or twice each season. In stables producing what is called certified milk, the floors are daily washed clean. In all cases, the manure should be romoved from the stable every day. The next 
best thing is to use plenty of litter, or bedding, to absorb the liquid manure. Great care should be taken to keep hogs under clean conditions. The losses from hog cholera would

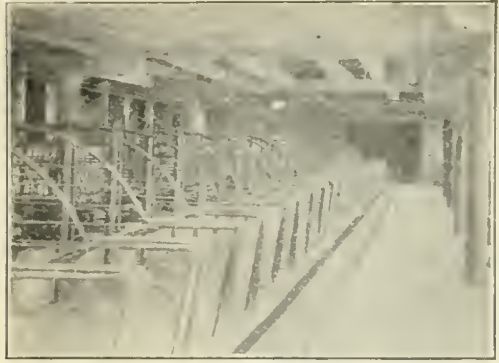

Fig. 162. The interior of a sanitary stable. Photograph by the author. be far less if the pig quarters were kept reasonably clean. Floors for stock to stand upon should be tightly made, whether of planks or other material. Cement is at present very popular, though not entirely satisfactory, owing to its cold, hard, and often damp surface. The liberal use of land plaster or slaked lime in the stable is excellent, for these absorb bad odors and sweeten the air.

The value of shelter for live stock has been much discussed, and in the past many stockmen have thought it necessary to keep stock in buildings well protected from cold. The most recent views are that elose, warm shelter is undesirable. Captain Hayes, a noted authority on horses, writing

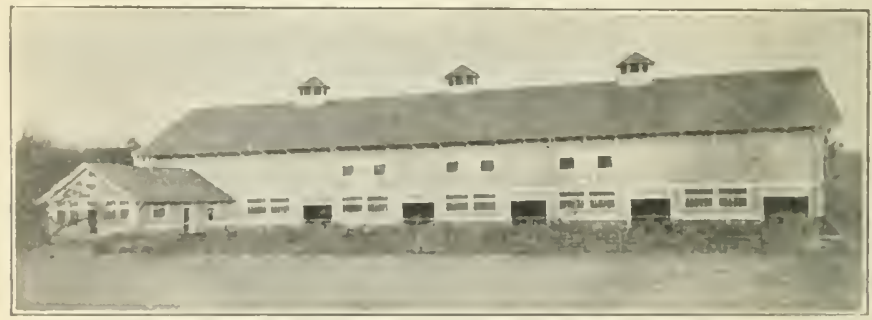

Fig. 163. The exterior of a modern stock barn, with first-clasa arrangements for ventilation and light. Photograph by courtesy of Oakleig! Thorne, of New lork. 
on the subject of the temperature of the stable, says:* "I have had many opportunities in Russia of comparing the relative healthiness, during very cold weather, of hot stables and of those kept at a natural temperature. In large towns in Russia the practice throughout the winter is to have stables at a temperature of from 50 to 60 degrees Fahrenheit, the difference between the temperature inside and outside being not infrequently over 80 degrees Fahrenheit.

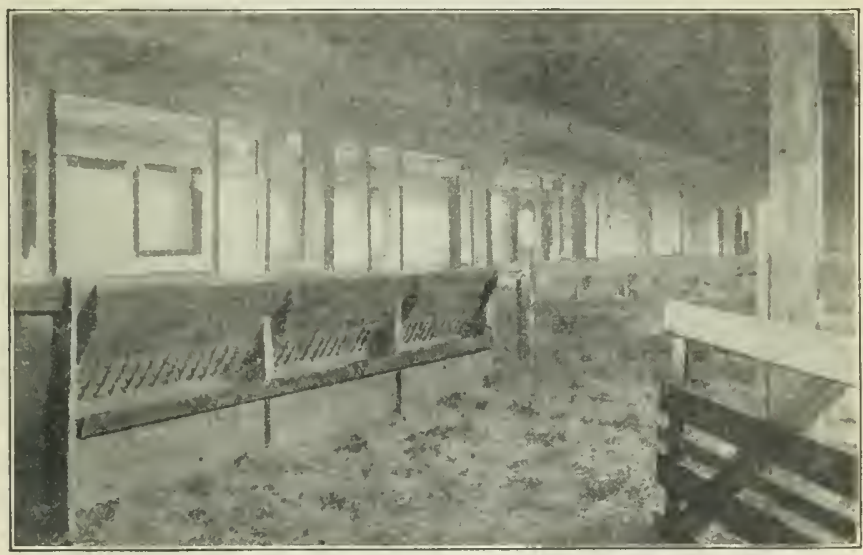

Fig. 164. A sheltered feed lot. Photograph by the author.

Consequently, influenza, inflammation of the eyes, and diseases of the organs of breathing, especially roaring among big horses, are common in these abodes. In the Russian cavalry remount depots an entirely different course is pursued; for the stables at these places are immensely roomy, very lofty, and are ventilated so freely and kept so clean, that even in the early mornings before the horses are taken out, the air inside is free from any suspicion of closeness.

*Stable Management and Exereise, 1900, p. 199. 
It is instructive to note that the horses kept in them maintain their health during the extremely cold winter in the same excellent manner as they do in summer."

Steers fed under sheds open to the south, with yards into which they can freely go, have given better results in growth and fattening than those kept in stalls in warm barns. President Waters, while at the Missouri station, found that steers fed in open sheds made an average daily gain of 1.9 pound, while those fed in the barn gained 1.7 pound.

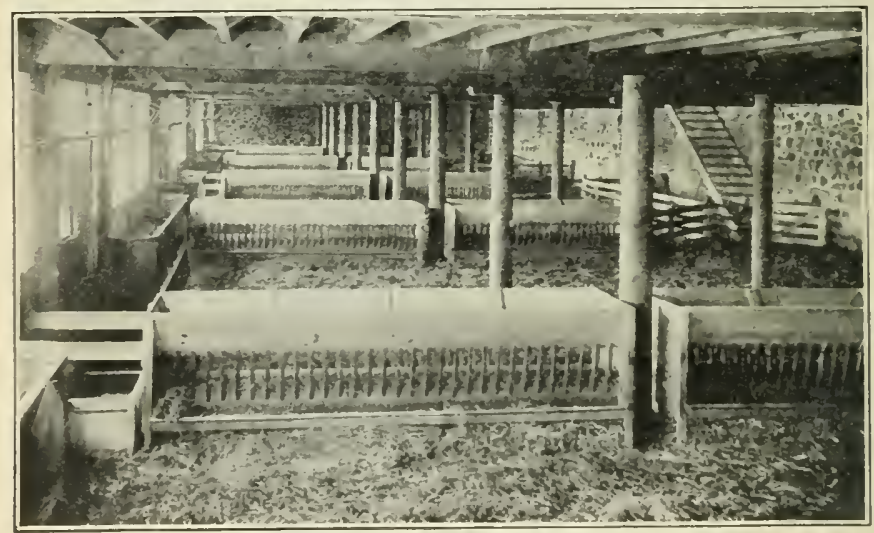

Fig. 165. The interior of $\mathbf{3}$ model sheep barn owned by Oakleigh Thorne, of New York. Photograph by courtesy of the owner.

Those fed in the open shed required less feed for a pound of gain than did the barn-fecl cattle. It has been found that the more farm animals have access to open air, and the less they are confined in stables, the healthier they will be, and the better use they will make of their feed. This especially applies to horses, beef cattle, sheep, and hogs, that are above weaning age. 
Shelter under good sheds, open to the south, with freedom from drafts, are the essential features of protection. Dairy cows are more sensitive to cold, and need more protection; consequently, the comfortable, well-lighted and ventilated stable is all right for these animals. Young animals should be given protection not only from severe cold, but also from excessive heat.

Ventilation of the stable is in these days receiving much attention. Many barns built in recent years in all parts of the country are constructed so as to have fresh air come in at the windows or the ceiling, with the bad air drawn out

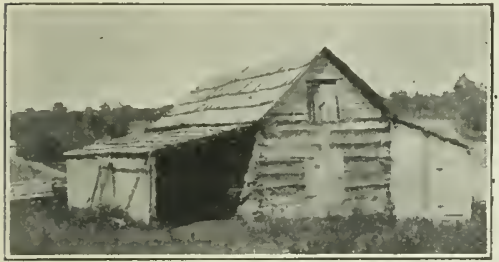

Fig. 166. An unsanitary, badly lighted barn. Photograph by the author. by flues in the wall, openings being near the floor. The King system, advocated by the late Professor F. H. King, of Wisconsin, has been extensively used. The important idea is to keep the stable air as fresh as possible. If the stable is too close, carbonic acid gas, breathed out by the animals, accumulates. Ordinary air contains from .02 to .06 per cent of this gas. If more than this prevails, breathing is more rapid, the heart beats more slowly, and diseases of the respiratory organs are likely to develop. Under the winter conditions of the North, a stable temperature of 40 to 45 degrees in freezing weather is preferable to one that is above that.

The stalls for the live stock naturally vary according to the size and kind of animal. Dr. Mayo recommends * stalls for horses to be $51 / 2$ to 6 feet wide, and $91 / 2$ feet long;

*The Care of Animals, 1903, pp. 18-19. 
and for eattle, from 38 to 45 inches wide and from 56 to 72 inches from the manger to the manure trench, according to size of animal. Captain Hayes advocates stalls for horses 6 feet wide, 10 feet long and 10 high. Box stalls, or loose boxes as some call them, should be about 10 by 12 feet in size for horses and eattle; for the larger horses 12 by 12 feet is better. For hogs and sheep, stalls are not made for individual animals, but instead pens are built to hold several head. The size of pens is a matter of choice. For hogs, 6 by 8 feet is about as small as they should be made. It is better to have pens too large rather than too small. The most popular flooring now in use is conerete, with a rough surface. Plenty of bedding will kecp such a floor dry and comfortable. Two-inch planks, closely laid with a slight fall toward the gutter, make excellent floors.

Exercise for the breeding stock is very essential. This promotes vigor and a good appetite. In fact, exercise is essential for the best health of any animal. The driver of a trotter looks after systematic, daily exercise, to keep his horse in the right condition. So does the caretaker of a heary draft stallion see that his charge is excreised daily with a walk of several miles. Professor Henry, discussing exercise, says:" "The highly-fed colt should be out of doors from 8 to 10 hours a day, and should move several miles each day, either in the field, or on the track, or both. A mature horse should be in the open air not less than 4 or 5 hours a day, and should travel from 10 to 15 miles daily to maintain health." Captain IIayes recommends for a sound horse three hours of excreise daily, or what would be better, four, divided into two and one-half hours in the morning and one and one-half in the afternoon. Bulls are often

*Fecds and Feeding, 1910, p. 298. 
turned into small lots or yards, where they usually keep more or less in aetion, thus getting the necessary exercise. Where animals are turned into fields or paddocks, as is usually the case where land is abundant, sufficient exercise is secured. One rule should always be applied in feeding work horses, and that is, if the amount of work or exereise is reduced, there should be some reduetion in the amount of feed given.

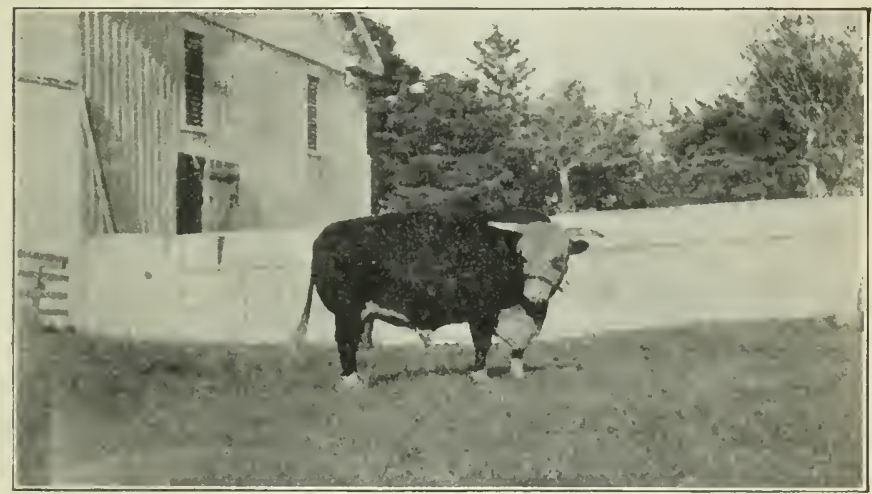

Fig. 167. A bull yard or paddock for exercise. Photograph by the author.

The amount of food required by an animal naturally depends upon circumstanees, sueh as age, size, kind, season of year, work, ete. As regards feeding hay, the common custom is to give an animal as much as it will eat. Grain is fed in widely different amounts. A hard-working horse on the farm will easily eat from 12 to 20 pounds of grain a day, depending on his size and the work done. About 2 pounds of hay and grain for each 100 pounds of live weight is regarded as a fair amount of feed for the hard-worked horse. From 8 to 10 quarts of oats a day for the earriage horse are recommended. Professor Henry gives the following amounts of 
grain for colts, as measured in oats, covering three periods of development.*

Up to 1 year of age, from 2 to 3 lbs.

From 1 to 2 years of age, 4 to 5 lbs.

From 2 to 3 years of age, 7 to 8 lbs.

Cattle are fed under a wide range of conditions, from those that receive no grain, to those on heavy feed. Beef cattle often receive a pound of grain for each 100 pounds of live weight, while undergoing fattening, though much more than this is fed when finishing them off. A common grain ration for dairy cows is 1 pound for every 3 pounds of milk produced. Sheep are not usually fed grain heavily, especially Merinos and breeding stock. Fattening sheep are given from $1 / 4$ pound to 2 pounds of grain per day, with 1 pound as a fairly good feed for medium-sized sheep. Growing pigs should be fed what they will eat up clean, yet not enough to be fattening. During fattening, one may figure on about 5 pounds of grain for each pound of gain in live weight. A feed of 7 pounds per day for a 200-pound hog is a very good-sized ration. Pasture of clover or alfalfa, or even blue grass, is very desirable for young pigs and brecding stock, and where available for feed much is saved on the grain bill.

Animals of the same age and kind should be kept together under conditions suitable for their best development. It is customary among the better class of stockmen to keep in groups by themselves, the nursing calves, the yearling and two-year-old heifers, the dry cows, and the producing cows. Bull calves, after two or three months old, should be scparated from the rest. Foals must be handled as individuals, and are valuable enough for separate stalls when not in the open lot or pasture. Fattening cattle, sheep, and hogs

*Feeds and Feeding, 1910, page 291. 
should be sorted out and each kind fed in its own group. Animals thus separated, according to their several needs, will get the best individual care, will be fed most nearly right, and will clevelop more satisfactorily than would be the case otherwise.

The care of the feet of animals is often negleeted. One of the most common defects is seen in too great a length of hoof. When the hoof grows too long, the toe becomes elevated and the heel depressed, giving a bad position. This does not occur so often with horses, as the blacksmith looks after the foot of this animal, but the feet of stabled cattle that are not exercised, frequently become very long. So also do the hoofs of sheep that are not rumning on fields with plenty of gravel or grit. The hoofs of cattle may be trimmed back with the aid of a good chisel and a farrier's rasp and knife. The thin hoofs of the sheep may be easily trimmed with a sharp pocket knife. Care should be taken not to eut into the tender part, or "quiek." The floor of the hoof should be level and the foot carried in a natural position. The feet of colts and young animals should be watched and trimmed as seems necessary.

\section{SUPPOSING YOURSELF IN CHARGE OF SOME LIVE STOCK}

1. Why should your personal attention be necessary?

2. How frequently would you feed and water?

3. What arguments would you have in behalf of grooming?

4. What would be necessary to secure a sanitary barn?

5. Under what conditions would you furnish shelter, and why?

6. Describe the ideal condition of ventilation.

7. What size of stalls would you provide?

8. How much feed would the horses and cattle require per head daily?

9. In what way would you group your animals and why?

10. Describe the development and care of the feet. 


\section{MAKE THE FOLLOWING NEIGHBORHOOD OBSERVATIONS}

11. A comparison of the best and poorest cared-for herds.

12. Records of hours of feeding of different kinds of stock by ten stockmen of your acquaintance.

13. If possible, visit and describe a sanitary stable.

14. Compare methods of exercising horses as seen about your home.

15. If living on the farm, measure, or better, weigh, the amount of grain eaten daily per head by some of the animals and compare with their live weight. 


\section{CHAPTER XXIV \\ TYPES AND BREEDS OF POULTRY}

A classification of a domestic poultry includes a number of different kinds, each consisting of a group with its types and breeds. The following is a classification commonly used.
1. Fowls and chickens.
5. Pheasants.
2. Turkeys.
6. Ducks.
3. Guineas.
7. Geese.
4. Peafowls.
8. Swans.

The types of domestic fowls (using the word fowls as referring to chickens) are six in number, ${ }^{*}$ as follows:

1. Game.

2. Egg.

3. Meat.

4. General purpose. 5. Deformed.

6. Bantam.

For some time poultry students have discussed these types, but more especially three, which from a practical point of view are the only ones of interest to the farmer. These three are the laying, the meat, and the general-purpose fowls. Good examples of each of these types are common all over the country. The other three types are rarely raised on the farm, being the product of the fancier, who oftentimes has his poultry outfit on a town lot. The breeds are also sometimes divided into two classes, sitters and non-sitters, according as to whether or not the hens have the desire to sit on and hatch a nest of eggs.

The egg type of fowl is somewhat slender of body, and has been compared to the racing horse, the dairy cow, and fine-wooled sheep. It is light of form, has a sprightly,

*Principles and Practices of Poultry Culture. John I1. Robinson. Ginn \& Co., 1912, p. 611, figs. 570 . 
active carriage of head and neck, is somewhat narrow in body, and has fairly slender legs and feet. Fowls of this type vary somewhat in size and weight, as well as in fleshproducing capacity. The Leghorns are small and do not produce much meat on the body, while the Minorcas are larger and may carry a good amount of flesh when in best condition. The fowls of this type are of European ancestry

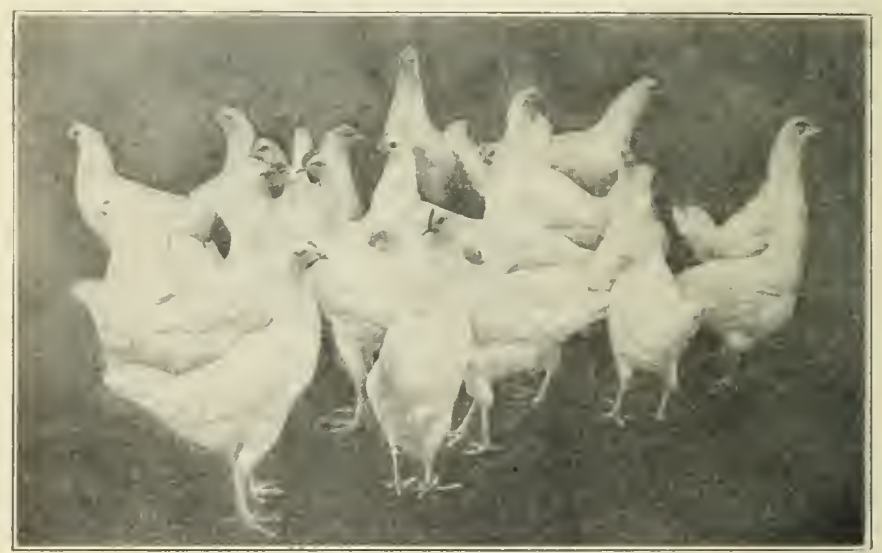

Fig. 168. The egg type of fowls. Photograph by courtesy the Poultry IIerald.

and are usually known as the Mediterranean breeds. Some breeds, like the Leghorns, are small, the hens weighing around 3 pounds, while Minorea females may weigh $6 \frac{1}{2}$ pounds.

The meat type of fowl is said to be comparable to the draft horse, beef cattle, mutton sheep, and the fat hog. It is squarcly built, compact, thickly fleshed, widle of back and breast, and heary of limb. Fowls of this type when fat have a carciss thickly covered with meat, and are especially valued for roasting. 'The hens, as a rule, are of sluggish 
disposition and are inferior egg-producers. The meat-type fowls sometimes weigh 10 to 12 pounds. They are of Asiatic origin, and are represented by the Brahma, Cochin, and Langshan breeds.

The general-purpose type of fowl, as might he supposed, is valued for both egg and meat production. This type is medium in size, has considerable fullness of breast and width of back, and fattens to advantage. In egg production some general-purpose breeds have excellent records. Standard weights vary, but 7 pounds for the hens and 9 for the eocks are satisfactory. Fowls of the general-purpose type, as a rule, belong to the American breeds, of which the Plymouth Rock, Wyandotte, and Rhode Island Red are the most common examples.

The breeds and varieties of fowls inclucle a large number, of wide

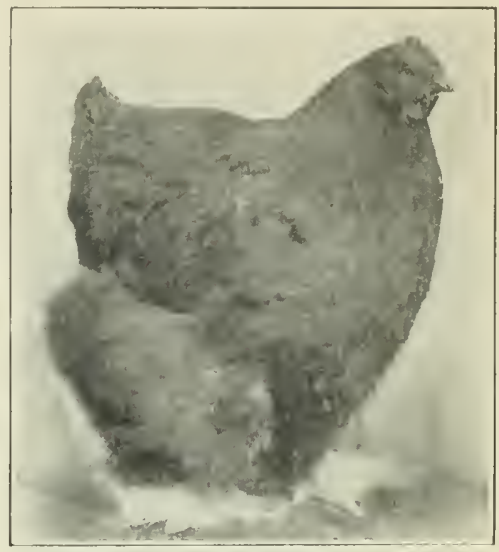

Fig. 169. The meat type. This is a Cochin. Photograph by courtesy of the Poultry Herald.

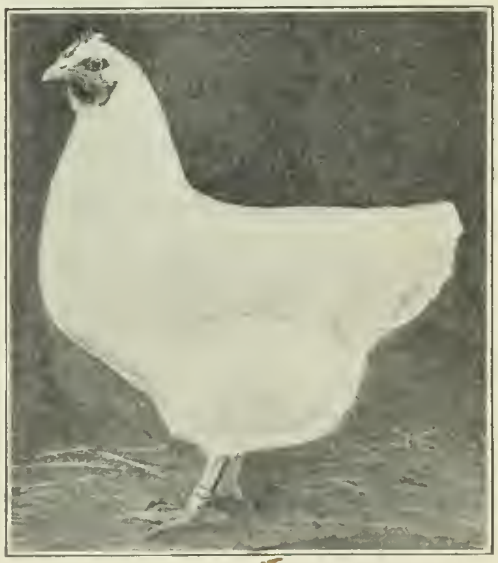

Fig. 170. The general-purpose type. A Plymouth Rock. Photograph by courtesy of the Poultry IIerald. 
difference, ranging from the tiny Bantam to the large and heavy Brahma. The breed characters of form, as applied to head, body, and legs, are rather distinet in each case. The variety characteristics are usually shown in color of feathers, though there may be other special features, such as single or rose comb. The Plymouth Rock, for example, includes six varieties; namely; (1) barred, (2) white, (3) buff, (4) silver penciled, (5) partridge, and (6)

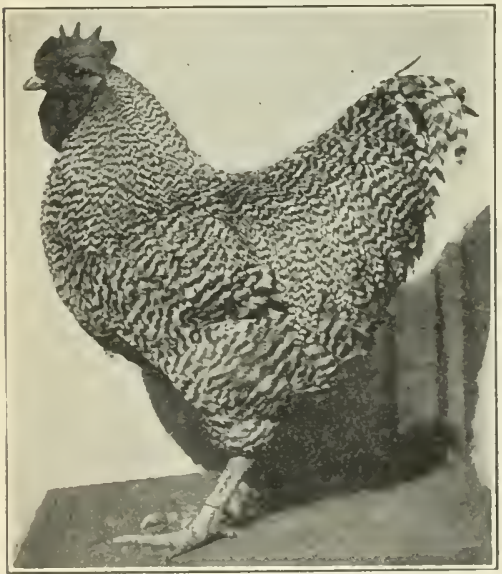

Fig. 17]. A Barred Plymouth Rock eoek, 1st prize Minneapolis, 1901. P'hotograph by courtesy the Poultry Herald.

Columbian. The following very brief descriptions of some of the leading breeds in America, include the more important representatives of each.

\section{The Plymouth Rock} originated in America, and is of medium size. The head is surmounted by a single, upright red comb, and the ear lobes and wattles are also red. The neck is broad, breast full and wide, back broad, and borly compact. Beak, legs, toes, and skin should be yellow in color. This breed is hardy and matures early, furnishing excellent broilers when eight to twelve weeks old. The hens are moderate layers, the eggs being of a brown color. This is a sitting breed, and the hens make excellent mothers. The mature males weigh $91 / 2$, and the females $7^{1 / 2}$ pounds. Varieties of this breed differ only in color of feathers. The Barred Plymouth Rock has been very popular in the past, though the whites are now meeting with much favor. 
The Wyandotte originated in Anerica, and is of medium size, with a form very similar to the Plymouth Roek. These two breeds look very much alike when fowls of the same eolor are compared. The Wyandotte, however, should have an outline of form somewhat more curved in its lines than the Plymouth Rock. This breed has a rose comb instead of a single form, and red ear lobes and wattles. The legs are yellow. Wyandottes are exeellent layers, and their eggs are of small size, brown in color. These fowls are valued for broiling and roasting, for their flesh is of fine grain and quality. The mature males have a standard weight of $81 / 2$ pounds and the females $61 / 2$ pounds. Wyandottes are extremely popular.

The Rhode Island Red originated in Rhode Island. The Ameriean

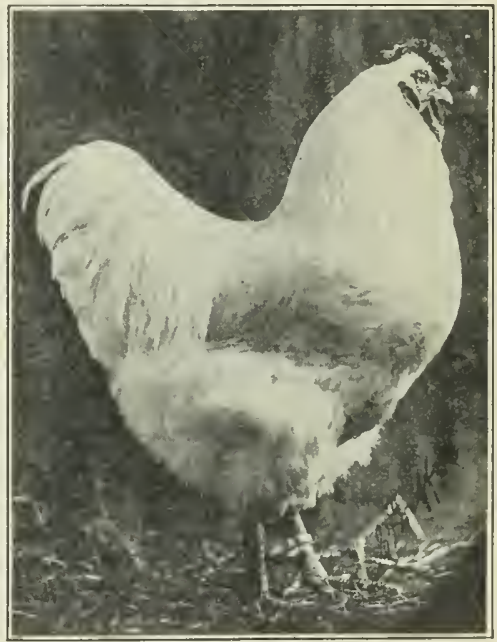

Fig. 172. A White Wyandotte cockerel, a 1st prize winner, owned by Mrs. E. W: Brooker. Photograph by courtesy of Poultry Success.

Standard of Perfection

states that "their chief characteristics are: red color, obiong shape, compact form, and smooth surface plumage." This is a medium-sized breed, mature males weighing $81 / 2$, and the females $61 / 2$ pounds. The comb is either single or rose in form, and of medium size. The shank and feet should be yellow or reddish horn in color. This breed has become quite popular on account 
of merit as a table fowl, and for excellence in egg production.

The Orpington was first developed in the town of Orpington, England, from which it receives its name. There is no great difference between this and the general-purpose American breeds, except that the Orpington is somewhat heavier, and has gray or whitish skin and black or flesh-colored legs. The comb may be of the single or rose form. The ear lobes are red. There are three varieties, white, black, and buff.

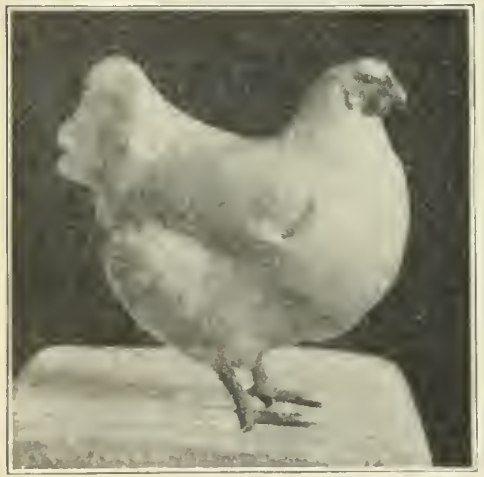

Fig. 173. A White Orpington hen. By courtesy of the Poultry Herald. The mature males weigh 10 and the females 8 pounds. The Orpington in recent years has become very popular, ranking high for table use and for egg production.

The Light Brahma is of Asiatic origin, and has been known in America for many years. It is strictly of the meat type, and is the largest breed of fowls, the mature males weighing 12 pounds and the females $91 / 2$ pounds. The heal is of medium size, with a small pea comb, medium sized, red wattles, and large red ear lobes. The breast is very broad and full, the back wide, the legs, toes, and skin yellow, and the shanks feathered. The neck, tail, and large wing feathers are black, and white striped with black, the other fouthers being white. This breed is ralued for roasting, lut does not rate ligh in egge poduction. 'There is another varicty called the Dark Bralmma, but neither is 
longer popular, and but few flocks are now kept, although they once were eommon.

The Cochin is also an Asiatie breed, large in size, like the Brahma, a standard weight for males being 11 pounds and for females $91 / 2$ pounds. This is a deep-bodied, massive fowl, having a loose plumage with much downy fiber underneath, which gives the entire body a fluffy appearance. The legs are heavily feathered. These fowls are valued for roasters rather than for egg production. There are four varieties of Coehins, buff, black, white, and partridge.

The Langshan is a singlecombed Asiatie breed, somewhat smaller and more active than the Brahma or Cochin, and much more popular, both for meat and for egg production. There are two varieties, the black and the white. The males weigh $91 / 2$ pounds and the females $71 / 2$ pounds, at maturity. There is much fullness of breast, and the form is compact. The legs of the black variety are bluish eolored, and slightly feathered. The comb, face, wattles, and ear lobes are bright red in color.

The Leghorn is a breed of European origin, getting its name from Leghorn, Italy. This is distinetly an egg-laying breed. The features of importance are, large, single, or rose comb, the single comb on the hens drooping to one side. The head is small, the eye of good size, ear lobes white, eomb and wattles red, and beak, legs, and skin yellow. The breast 
is prominent, though not very wide; the back of medium wilth and length, the feathers snugly laid to the body, and

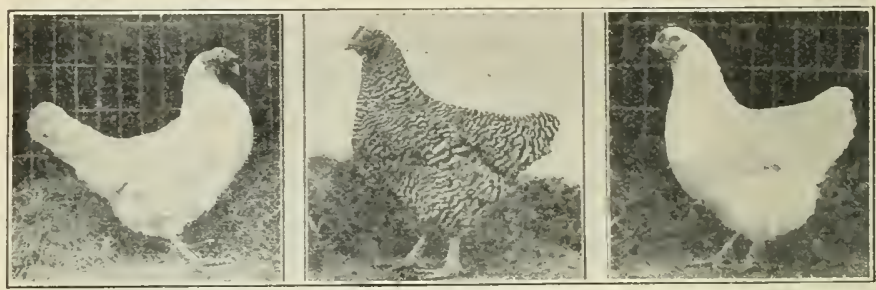

Fig. 175. Three hens owned by the Cyphers Incubator Co. The White Leghorn laid 251 eggs, the Barred Plymouth Rock 236, and the White Wyandotte 237, each within a year. By courtesy The Cyphers lncubator Company.

the tail carried erect. The Leghorn is very hardy and one of the most active breeds of fowl, rather small of size, and famous for egg production. The females are non-sitters.

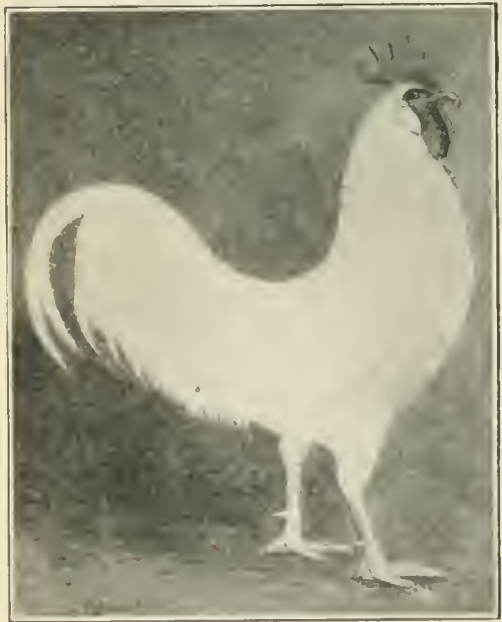

Fig. 176. A Whito Leglorn rockerel. Drawing by courtesy of Poultry Succcss.
There is no stanclard of weight at maturity, but males weigh about 4 and females 3 pounds. There are several varieties of Leghorns, of which the white, brown, and buff are most common. This is one of the most common breeds kept on the American farm.

The Minorca is an egrglaying, non-sitting breed, originating on the island of Minorea, in the Mediterranean Sea. The following is quoted from the 
American Standard of Perfection: "They are distinguished by long bodies, very large combs, long and full wattles, large white ear lobes, dark-colored legs, and pinkish-white or flesh-colored skin. The Minorca head is carried rather high; the back is long and sloping; the tail is spread some degrees from the horizontal. Their legs are firm, muscular, and set squarely under the long, powerful-looking bodies." There are both single and rose comb strains of this breed. As egg producers the Minorcas rank very high, the egg being very large and white.

There are a number of other breeds of fowls, but these are usually kept only in a small way by poultry fanciers, and do not require attention here.

The bantam may be a divarf of some of the larger breeds or a distinct breed. Bantams are kept for ornamental purposes, and

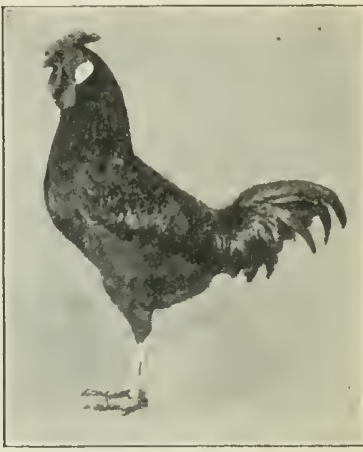

Fig. 177. A Minorea cockerel By courtesy the Poultry Herald. have no practical value. The weights naturally vary somewhat, but 26 ounces for mature males, and 22 ounces for the females are standards. The Cochin and Brahma bantams weigh slightly more, 30 ounces for the male and 26 for the female. The bantams make very interesting pets for children.

\section{THE TURKEY}

The turkey is a native of America and was unknown in Europe previous to 1624. The present domesticated turkey originated from the wild stock which once was found in large numbers in this country, and is yet found to a small extent in certain parts of Pennsylvania and the 
Southern states. We have really but one breed of turkey, all variations in color and size being simply differences in varieties. According to the Standard of Perfection of the American Poultry Association, the frame should be large, the body deep, "with a broad, round, full breast that varies in prominence according to the variety." The head snouid be of good size, and the eyes bright and alert. The leg and

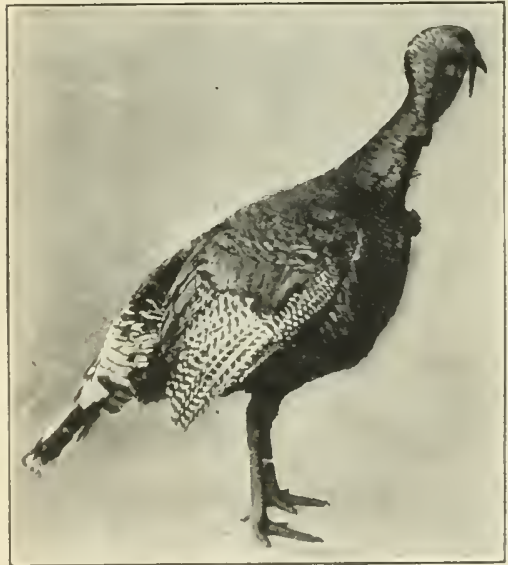

Fig. 178. A male turkey. Photograph by courtesy of the Poultry Herald. shank bones should be large, straight, and well set. The carriage should be proud and erect.

The Bronze turkey is very large, and the feathers are bronze or brown black, with shadings of color. The standard weight for an adult male is 36 pounds, and for the hen, 20 pounds. This is the most common variety raised.

The Narragansett turkey is of a metallic black color, with shadings to steel gray or approaching white. The White Holland, as its name indicates, has a white plumage. There are also black, buff, and slate varieties, each having a standard weight of 27 pounds for the mature male and 12 pounds for the leen.

\section{THE DLCK}

The Mallard or common wild duck is regarded as the parent stock, or ancestor, of all clomestic ducks. The duck 
has a broad flat bill, small eye, good-sized head, long neck, full breast, long body, short tail, and short web-footed legs. The body has a dense covering of downy feathers, over which lies the feathery plumage. The thickness of plumage, which is slightly oiled by natural secretion, prevents water from penetrating among the feathers.

Three types of ducks are recognized, meat, egg-laying, and ornamental. Those which best supply the needs of the table for meat are most in demand.

The Pekin duck was brought to England from Pekin, China, in 1874. It is white in color and of large size, weighing 7 to 9 pounds, and is the most popular duck for table use. The bill is orange-yellow in color, while the shanks and toes are reddish orange.

\section{The Aylesbury duck is} white and much resembles the Pekin. The bill

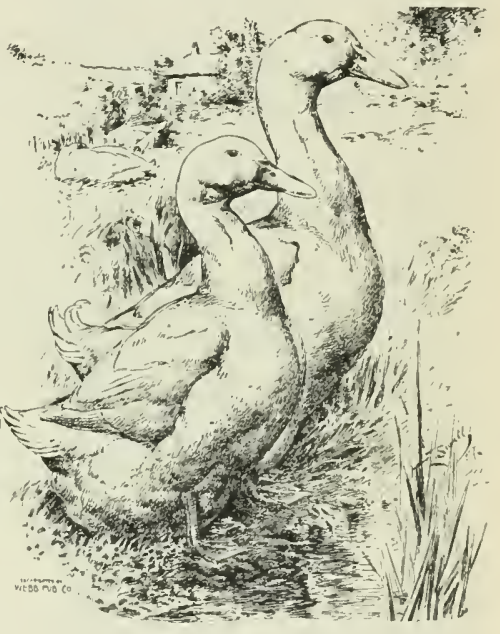

Fig. 179. A pair of Pekin ducks. Reproduced from the "Poultry Manual." is flesh-colored, and the legs and feet are pale orange. These ducks are more popular in England, where they have been bred many years, than they are in America.

The Rouen duck is a breed that takes its name from a eity in northern France, where it has long been bred. It is grayish in color, with dark shadings or black on head, neck, wings, and back. The bill is of greenisir-yellow color, and the legs and feet orange with a green or brown shade. 
The Cayuga duck originated in Cayuga County, New York. It is greenish-black in color, except some of the large

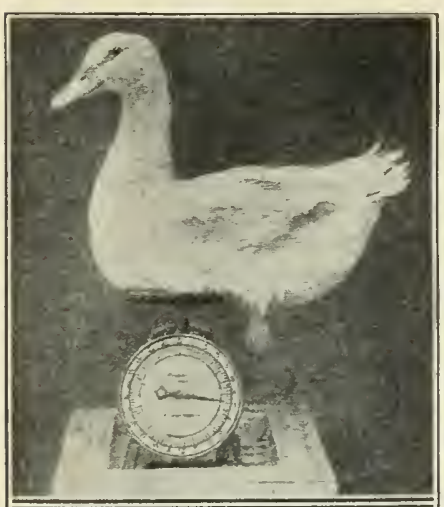
wing feathers, which are brown. The bill is black, and the legs preferably black, though slate color occurs.

The Muscovy duck is a native of South America. In size it is very large, adult drakes weighing 10 pounds and females 7 pounds. The body is long and broad, and is carried nearly horizontally. The head is rather long, and large with the male, and has large crest-like feathers, which the duck often raises when excited. The head is partly bare of feathers, and the sides and top above the bill have rough wart-like coverings known as caruncles, which are recl of color and rather conspicuous. The bill is pink or flesh-colored. Colored muscovys have yellow to dark leadcolored legs, while those of the white variety are yellow. The plumage varies in color, but white or black-and-white

Fig. 180. "Rapid growth" Prkin ducks produced on Cyphers Company Poultry Farm. Age, 8 weeks. Note their weights.
Cvnhers Incubstor Cu. are the favorite varieties. Ducks of this breed fly much 
more than do others, and sometimes perch on elevated places.

The Indian Runner duck is supposed to have originated in India. It is rather small, a standard weight being about 4 pounds at maturity. The body, which is long and narrow, is carried somewhat erect, after the style of the wild penguin. The popular color is fawn or gray and white. The claim is made that the young ducks at 6 weeks of age dress into

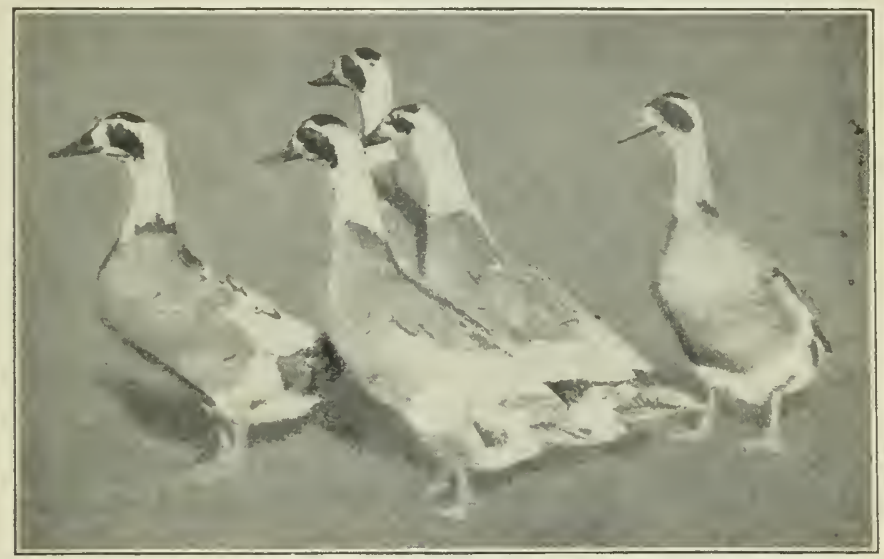

Fig. 1S1. Indian Runner ducks, called the Leghorn of the duck family. Reproduced from the "Poultry Manual."

broilers weighing $21 / 2$ to 3 pounds. This duck, however, is valued chiefly for egg production, a female oceasionally laying as many as 200 eggs in a year.

THE GOOSE

The domesticated breeds of geese have been developed from the wild breeds. The common wild goose of America is often domesticated and kept in confinerínent. There are several breeds of importance. 


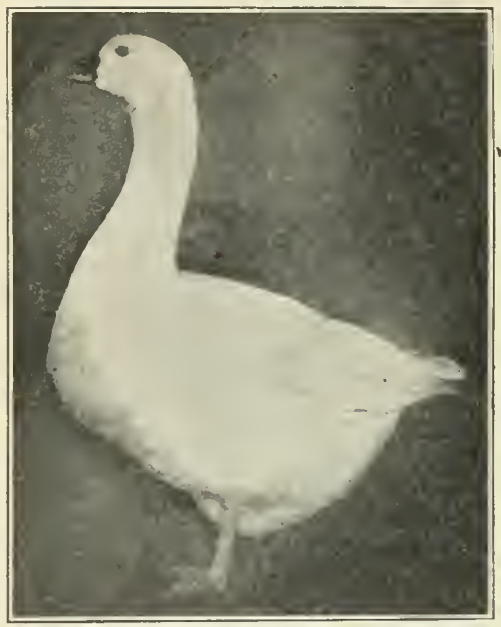

Fig. 182. An Embden goose. Photograph by courtesy the Poultry Herald.

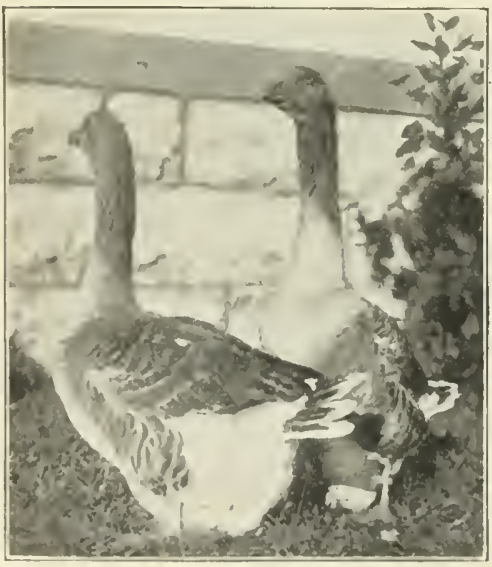

Fig. 183. Toulnise gense. By courtesy the Poulliry llerald.
The Embden goose is of European origin. It is of medium size, adult ganders weighing about 20 pounds. The bill and legs are orange in color, and the plumage is white. This is a very popular breed.

The Toulouse goose gets its name from a city of that name in France. It is of large size, adults weighing about 25 pounds. The bill is pale orange and the legs a deep shade of that color. The plumage is gray, with dark shadings about the neck, back, wings, and breast.

Most of our domestic flocks consist of these two breeds.

\section{SUGGESTIONS FOR} REFLECTION

1. What makes the six types of domestic fowls?

2. Describe the egg-laying type of hen.

3. What is the difference between a breed and a vilriety?

1. Compare the Plymouth Ruck and the IIyounlotte. 
5. Compare the Light Brahma and the Leghorn.

6. Name the place of origin of each of five breeds of fowls.

7. Discuss the origin of the turkey.

8. What are common features of different breeds of ducks?

9. Compare the Pekin and Rouen ducks.

10. What are some of the most striking characteristics of the Muscory duck?

\section{DO YOU THINK YOU COULD}

11. Give the names of five men keeping pure-bred poultry in your neighborhood, and the breeds they keep?

12. Bring a small collection of eggs of different breeds to school?

13. Interest loeal poultrymen to arrange a small poultry show for the benefit of the school?

14. Weigh some specimens of live poultry of different breeds and report on the age and weight of each?

15. Bring to school specimens of feathers showing breed colors? 


\section{CHAPTER XXY}

\section{JUDGING POULTRY AND POULTRY PRODUCTS}

The poultry judge who understands his work must be familiar with many details. There is in this country an organization known as the American Poultry Association. This derotes much attention to the establishment of standards of perfection for the various breeds and varieties of fowls, and provides rules and methods for judging fowls. A book published by the association, known as the "Standard of Perfection," is the American authority for judges and students to follow. No poultry show could be properly conducted without the judge being guided by this standard. No breed of fowls ean be considered established until officially recognized and deseribed by the American Poultry Association.

The parts of the fowl passed on by the judge have certain outlines, colors, and other markings as applied to each breed. The feathers differ in size and form in a striking way, according to their location on the body. The illustration of a male bird on page 341 shows, through a numbering system, the location of the parts and feathers.

The head of the fowl is one of the striking breed features. It is topped with a comb, which is larger on the cocks than on the hens. A very common form is single, upright or loppecl, the top being serrated, or separated into points suggesting the teeth of a saw. Leghorn and Plymouth Rock varieties have this form. The rose comb is wide and low, consisting of many knohs erowded together, the rear part tapering more or less to a smooth point. This comb oceurs 


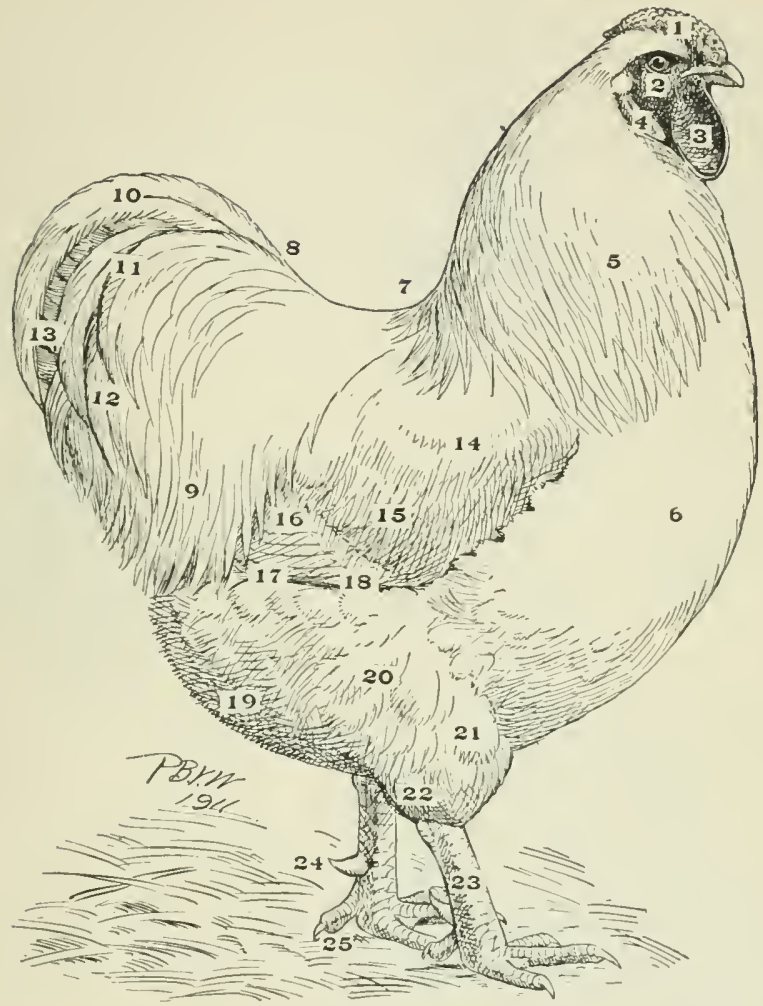

Fig. 184. The exterior of the fowl. Drawing by courtesy of Poultry Success.

1. Comb.

2. Face,

3. Wattles.

4. Ear lobe.

5. Hackle feathers.

6. Breast.

7. Back.

8. Sarldle.

9. Saddle feathers.
10. Sickle feathers.

11. Lesser sickle feathers.

12. Tail coverts.

13. Main tail feathers.

14. Wing bone feathers.

15. Wing coverts, forming wing bar.

16. Secondary feathers, wing bay.
17. Primaries or flight feathers.

18. Flight coverts.

19. Fluff.

20. Body feathers.

21. Thigh.

22. knee joint.

23 Shank.

24. Spur.

25. Toe or claw. 
on Wyandottes, Minoreas, and other varieties. The pea comb is very small, and resembles three single combs dwarfed in size and crowded side by side, with the central one somewhat larger than the others. There are also V-shaped and strawberry combs, but these are not common. The ear lobes are usually small, and vary in color from red to white or bluish, according to breed. The wattles are usually red, and on the cock often hang below the bill in a conspicuous manner. The bill does not show the striking differences

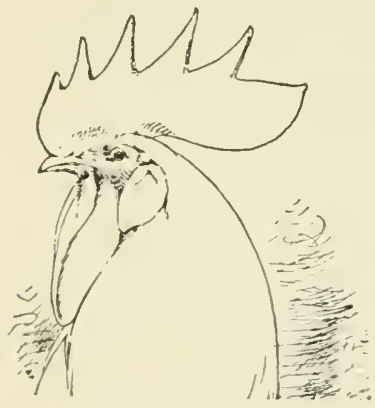

Fig. 1S.5. The serrated, single comb of the Leghorn. Reproduced from the "Poultry IIanual."

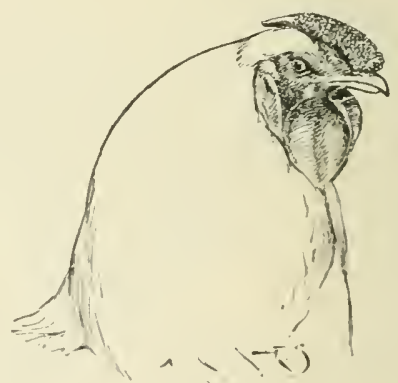

Fig. 166. A rose comb.

seen in the comb and wattles. Some breeds, like the Houdan and Polish, have erests, or elusters of feathers, which sometimes largely hide the head proper from view and also often affect the sight.

The feathers of the fowl differ in a remarkable way in size, form, and color. Even with varieties of one color, as for example white, the shades of this hue are made a sulject of diseussion by poultry experts. This also applies to other solid eolors. In the case of fowls having more than one colormarking to the feather, there are barred feathers, as with the Plymouth Rock; penciled feathers, as with the Silver Pen- 
ciled Wyandotte; laced feathers, as with the Golden Wyandotte; and still other markings, as striped, spangled, edged, ete. The color-markings of some birds are very beautiful. The correct color and form of the feather are of most inter-

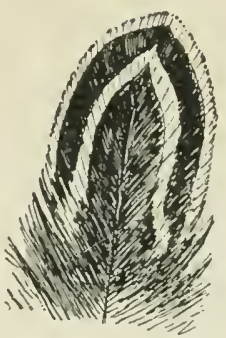

Fig 189 . Striped featherg of Partridge Cochin., Reproduced from the "Poultry Manual."

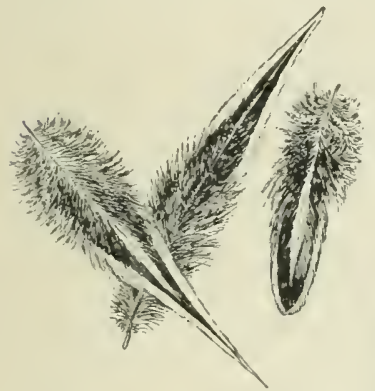

Fig. 188. Laced feathers from Laced Wyandotte. Reproduced from the "Poultry Manual."

\section{Methods of judging.} There are two methods of judging fowls, by score eard and by comparison. The seorecard method has been generally used at poul-

try shows for many years. Its use, however, is not so common now as formerly. Poultry-judges using the score card put down the number of points or fraction

est to the fancier; yet the practical poultryman little interested in this feature has been able to secure his favorite breed through patient breeding, development, and improvement by the so-called fancier.

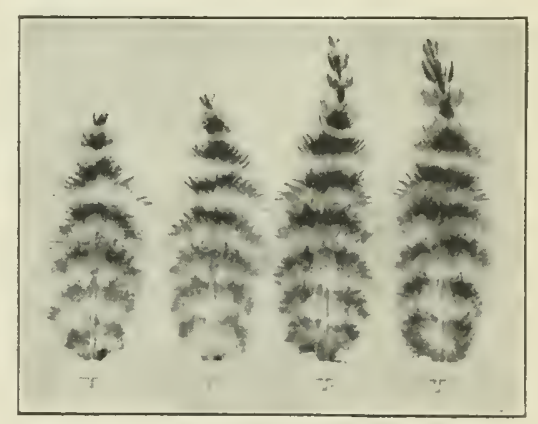

Fig. 187. Barred Plymouth Rock feather. Reproduced from the "Poultry Manual." 
of a point cut, and adding these, deduct from 100, which gives the total score. In cutting for defects, from $1 / 2$ to 3 points are recommended for certain deficiencies, and these are specified in the standard for the benefit of official judges. Judging by comparison is becoming common, and is more satisfactory than by score card, for the reasons already given in Chapter VII.

The official score card of the American Poultry Association is here given:

\section{(Name of association here)}

(Date, month, days and year show is held)

Officlal Score Card of the American Poultry Association

ExHIBITOR . .

VARIETY .

SEX

ENTRY No.

Band No

WEIGHT

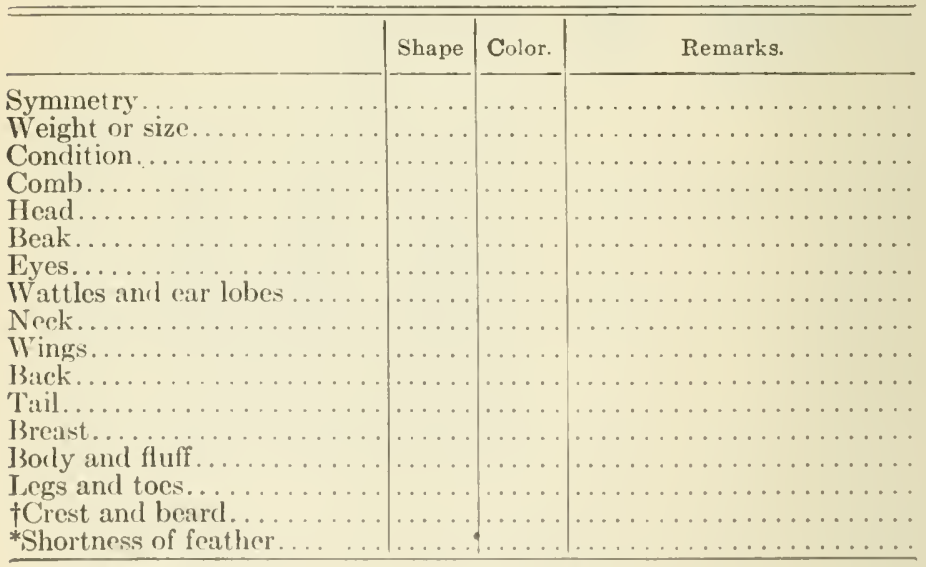

Total cuts.

Score.

JUDGE

Secretary

$\dagger$ Applies to erested breeds. *Applies to games and game bantams. 
This score card is intended for use in eonnection with the Standard of Perfeetion, which eontains a detailed deseription of each variety of fowl.

Instructions for judges of poultry include various points. Among these, weight receives eonsiderable attention, and two points are usually dedueted for each pound that the fowl falls short of the standard weight. Other things being equal, the one nearest standard weight is awarded the prize. To receive a first prize, a specimen must score 90 or more.points, except cocks in parti-colored varieties, which are allowed 88 points as a minimum. When young and old birds are in competition, other things being equal, the older ones are to be awarded the prizes. Ties often result in judging. When this occurs, if the tie eannot be broken by other rules, then the specimen receiving the smallest total sum of euts for shape shall be awarded the prize.

Disqualification in judging poultry is allowed for various reasons. The oceurrence of feathers on the legs of what should be a smooth-legged breed; or of smooth legs when feathers should oecur; improper color of ear lobes and legs; excessive number of toes, or too few toes; absence of erest in crested varieties; etc., are examples of conditions which justify disqualification.

Judging poultry products, such as dressed poultry and eggs, is becoming more and more necessary. The seore card is not specially recommended for this purpose, the comparative method being best. Referring to this point, one authority says:* "In judging dressed poultry and eggs, the number of qualities or points to be considered is small; slight differences in quality do not make great differences in value, as in high-class birds, and degrees of quality are more readily

*John H. Robinson: Principles and Practice of Poultry Culture, 1911. 
appreeiated. Thile seore cards are sometimes used for judging dressed poultry and eggs, the number of sections into which a card may appropriately be divided is so small that there is little if any advantage in scoring, and if, to develop a system of scoring, many sections are made, the process of judging is complicated when it should remain simple. The points to be considered are so few, and the values so apparent, that judgment of all is practically instantaneous. * * * The rational method of judging dressed poultry and eggs is to grade them according to market quality and value."

The judging of eggs by score card has been attempted to some extent. An egg show, in which eggs were scored by the students, has been held annually at Purdue University. Two classes of eggs were provided, "fancy" and "commercial." The following score card and explanation of its use are well worth consideration:

Commercial Egg Score Card

Fixнibitor.............. DAte...........191-

Address. . . . . . . . . . . . . . Color . . . . . . . . . . .

Extry No...... Class........ Weight. .......... Ozs.

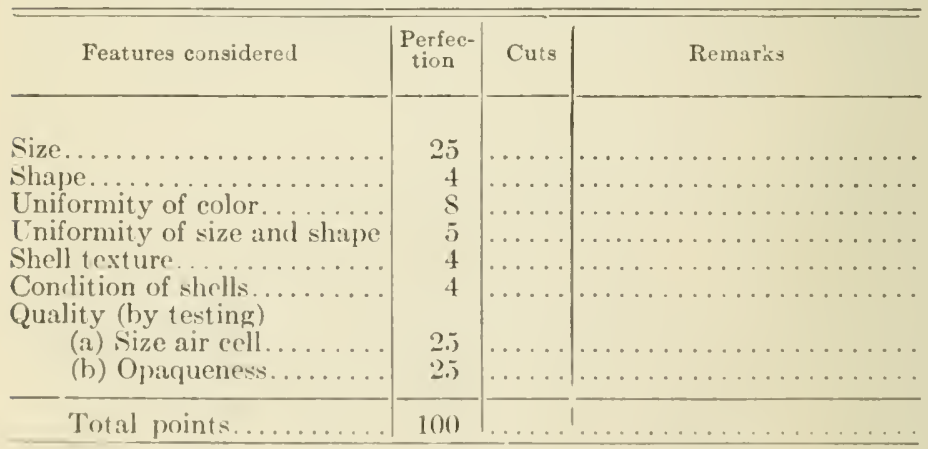

JUDGE 


\section{EXPLANATION OF COMMERCIAL EGG SCORE CARD}

Size: Extras, 26 to 28 ounces. Firsts, 24 to 26 ounces. One point cut for each ounce over or under required weight in either class.

Shape: $1 / 3$ point allowed for each egg.

Uniformity of color: If white, eggs should be all pure white and of the same shade. If brown, the color may be any shade, but the dozen should be uniformly the same color; $2 / 3$ point allowed for each egg.

Uniformity of size and shape: All eggs must be of same size and shape. $1 / 3$ point allowed for each egg.

Shell texture: Free from wrinkles, spots, cracks, and rough places; $1 / 3$ point for each egg.

Condition of shell: Free from dirt or stain, unwashed.

Quality: Test with candles. (a) Air cell very small, about size of a dime, indicating freshness. (b) Egg must appear opaque, the yolk free from dark color, white thick, yolk barely visible. Large air cell, floating yolks or air cells are defects. Eggs must be fresh and sweet.

Disqualification: Cracked, broken, spots, musty rots, and germs or blood rings in any one egg will disqualify the dozen.

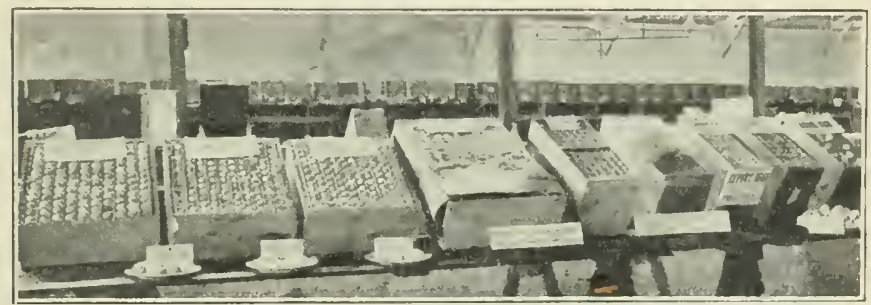

Fig. 190. An egg show. Photograph by courtesy the Poultry I/erald. 


\section{COULD YOU TELL}

1. The purpose and value of the Standard of Perfection?

2. How the combs of fowls differ in form?

3. In what way feathers differ in coloring?

4. The method of making cuts in scoring poultry?

5. How weight and size are graded by the judge?

6. Two conditions that might cause disqualifications?

7. Why the score card is not used more in judging poultry products?

S. The features of a commercial score card?

\section{EASY THINGS TO DO}

9. Holding Saturday afternoon poultry judging contests.

10. Collecting an exhibit of one breed for comparison at school.

11. Getting up a prize egg show, and judging by score card.

12. Sorting over and studying a case of eggs loaned by the eggdealer or grocer. 


\section{CHAPTER XXVI \\ EGGS AND INCUBATION}

The egg is an object of much interest, for not only is it the source of the chicken itself, but it is also a most important source of income to the poultryman. If one is to handle the egg intelligently, he must know something of its composition, of how the chick is developed within the shell, and of commercial differences and values.

The parts of the egg of special interest are five. These are the following:

a. The shell, composed mostly of lime, and hard enough. to enclose and protect the softer interior.

b. Two tough membranes lying next within the shell. These separate at the large end, forming a small air sac, which is easily seen in hard-boiled eggs.

c. The albumen, or as it is commonly called, the white of the egg. This forms about 57 per cent of the egg and consists of much nitrogenous matter of a liquid, sticky, transparent character. Boiling hardens or coagulates the white into a firm, white structure.

d. The yolk, comprising about 33 per cent of the egg, is a round yellow sac, surrounded by the white. This is used for nourishing the young chick just before and after leaving the shell. The yolk is suspended midway in the white and kept in proper position by two albuminous cords.

e. The germ, in the fresh-laid egg is seen as a white speck about one-eighth of an inch in diameter on the upper side of the yolk. The germ is the true egg and source of the chick in incubation. 
The fertile egg is one that will produce a chick under proper conditions of what is called incubation. The infertile or sterile egg cannot be hatehed, and so has no value in reproduetion, although for food it has equal value with the fertile one. The fertility of the egg cannot be determined except by incubation. After the egg has been under the hen for five to seven days, ordinarily one may easily tell whether it is fertile or infertile. If the latter, it will appear elear and show none of the changes deseribed in the following.

The testing or candling of eggs is a simple process of looking through the egg with the aid of special light. One may take a pieee of common eardboard, one side of which is black, in which is cut an oval hole not quite as large as an egg. If the cardboard is held before a lighted lamp in a dark room, blackened sicle towards one, and an egg is held in the hole, those that contain chieks will appear dark and opaque except at the larger end, while sterile eggs will be clear and show light. In the trade, where all eggs are examined before a light, this process is known as candling. Black lamp chimneys with holes in them are marle for use in a small way, but in the larger commereial trade, eggs are eandled over sets of lights arranged for this purpose.

The incubation of the egg of the hen oceupies a period of 21 days. The following are some of the more important changes that take place during ineubation. During the first twent y-four hours the germ enlarges to about a half ineh in size, within which the first stages of head and some other parts appear. During the second day the heart begins to beat and the blood to flow. By the end of the third day the veins and arteries are considerably developed, and the young chick turns on its left side. On the fourth day the wing folds, and the folds forming the legs appear. The beak begins to form on the eighth day, and shows its horny shape 
on the twelfth. The entire shell except the air cell is occupied by the chick by the twolfth day. The feathers appear first on the eighth day, and by the thirtcenth cover the body to the length of one-fourth inch. At this time the nails of the feet appear. On the fourteenth day the chick changes its position and extends lengthwise, the beak reaching the inner shell membrane. The air cell has been gradually increasing in size, and by this time is much larger. From now on, the chick increases in development to the twenty-first day. The following interesting description of the hatching process is given by Professor Lewis:*

"When ready to come out, the chick raises its head and pierces the inner shell membrane, and immediately starts breathing the air in the chamber, which causes the pulmonary circulation to become active and the embryonic circulation to cease. The head is next raised into the air chamber, and the chick deals blows upon the shell, which when often repeated in the same place result in fracturing it. This process is repeated until the shell is broken around about one-third of the way from the large end. The chick then presses its head against the large end and its feet against the small end, and then by pushing is able to throw off the shell lid and make its exit."

The temperature of the egg during incubation should be about 103 degrees. The usual temperature of the borly of the hen is 106 degrees, and her eggs from 102 to 104 degrees. The egg must be kept close to this temperature, and serious variation from this will kill the chick in the egg. During the first week a tomperature of 102 is best, but this may increase to 103 degrees the last part of incubation. After the third or fourth day the eggs being incubated should be turned once or twice daily.

*Poultry Laboratory Guide, 1910, p. 47. 
The need of moisture during incubation is commonly recognized. The egg contains from 60 to 65 per cent water and during incubation some of this is lost. In experiments it has been shown that eggs lose from 11 to 17 per cent of their original weight by evaporation. Professor Atwood, of the West Virginia experiment station, has estimated that 100 fertile eggs will lose about $8 \frac{1}{4}$ ounces of moisture during the first five days, about 12 ounces during the following seven days, and slightly more during the next seven days. Thus it can be seen that moisture must be provided to some extent during incubation.

The need of ventilation during incubation is also well understood. The movement of air about the eggs must be somewhat free, the air being neither too dry or too moist. The hen shifts her position from time to time, and so brings

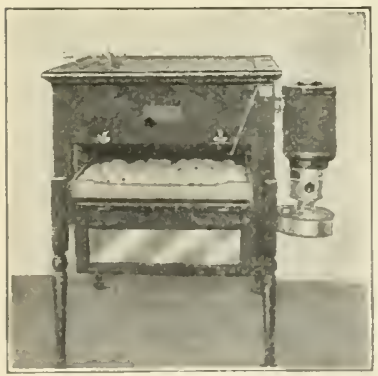

Fig. 191. An incubator and lamp. Photograph by rourtesy College of Agriculture, Ohio State University.

Universic. fresh air in contact with the eggs and her body. In artificial incubation, proper ventilation is so provided that the pure air and right moisture conditions go together.

The incubator is a box-like device containing a space in which cggs may be incubated by means of artificial heat. The hatching of eggs by artificial incubation has been in operation for thousands of years, especially in Egypt and China. There are various designs of incubators made, ranging in size from those to contain but a few eggs, up to those with a capacity for thousands. Incubators in use at the present time are heated by hot air from a kerosene lamp, or by a hot water system. 'The hot air type is the one 
in more common use. The eggs, one layer deep, are placed in moveable, wire-bottomed trays. The temperature of the incubator is regulated by the automatic action of an instrument called a thermostat, which is sensitive to heat changes. This instrument is set so as to reduce or increase automatically the amount of incoming pure air. A thermometer within may be read through the glass front. Incubators should stand level, and a popular location in which to operate them is a dry cellar that holds a uniform temperature.

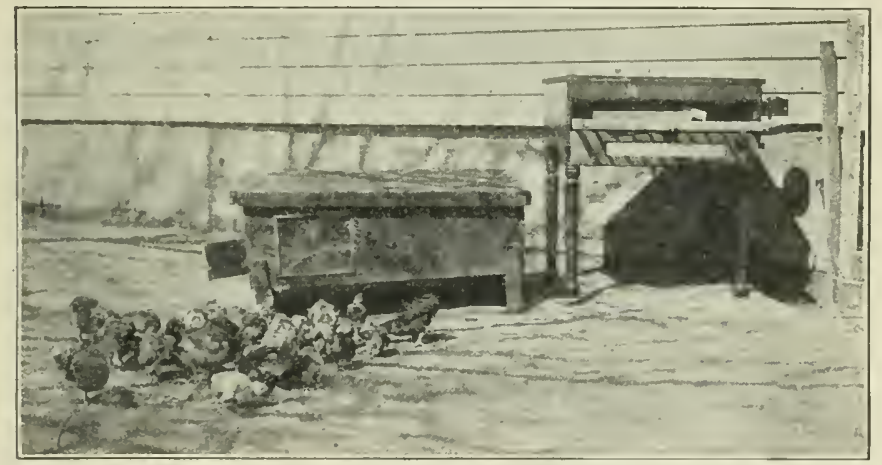

Fig. 192. A home-made brooder and incubator. Photograph by courtesy Ohio State University College of Agriculture.

A brooder is a device used in connection with the incubator, and is in a sense an artificial mother. The general plan of the brooder is that of a warm box or room, heated by a lamp or hot-water plant. A circular plate about two feet in diameter is placed about ten inches above the floor. A rim extending downward about four inches is attached to this, below which is fastened a heavy cloth eurtain extending to the floor. Pieces of cloth are also dropped from different parts of the under side of the cover to the floor. Here and 
there the cloth is slit so that the chicks may freely pass through and find a warm protection among the strips of cloth, comparable to being under the mother's wings. This special arrangement within the brooder is called a hover.

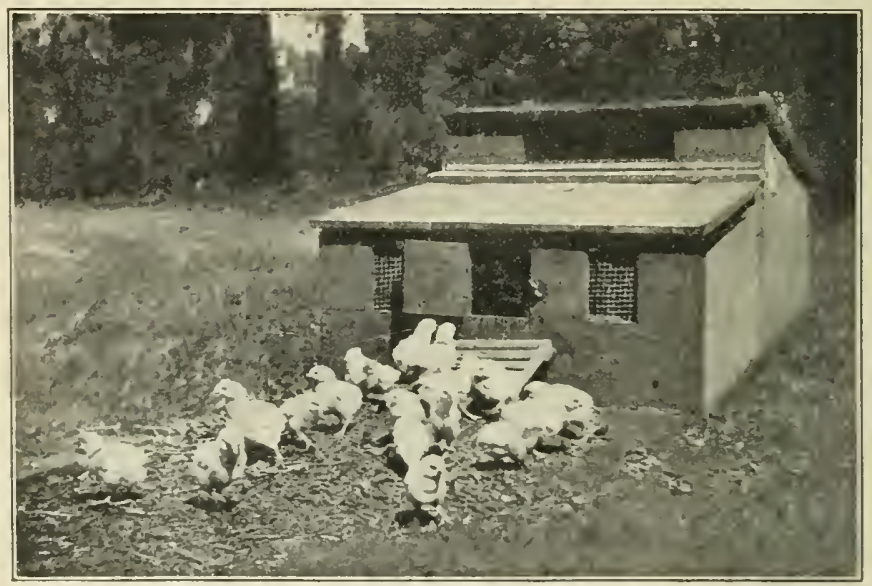

Fig. 193. A cheap brooder house, with brood. Photograph by courtesy the Poultry Herald.

The small brooder house usually has one hover, but large brooder houses have series of them, each of which is heated by a hot water pipe system.

Eggs for incubation should be from vigorous, well-mated fowls, and not from what might be called mongrel stock. These eggs should be kept in a dry, cool atmosphere until placed under the hen or in the incubator. A place having a temperature of from 50 to 60 degrees Fahrenheit is considered best. The eggs should be carefully handled, not being severely shaken or cracked. It is a good plan to mark on each egg the date laid, and no eggs over 21 days old should be set. In making up suttings, it is desirable to use those of 
uniform size and condition. Hatchings will be likely to be more uniform if the eggs are of much the same age and condition of keep previous to setting.

The size and weight of eggs vary more than many suppose. Professor Lewis gives* some interesting figures about the size and weight of eggs of different breeds of fowls. The eggs of seven different breeds showed an average large circumference of 6.19 inches, a small circumference of 5.27 inches, and an average weight of 1 pound, 8.05 ounees. The eggs from the hens were slightly larger and weighed a trifle more than those from the pullets. A dozen Plymouth Rock eggs weighed 1 pound, 11.2 ounces; the Leghorns ranking second at 1 pound, 10.3 ounces. In a bulletin published by the Ohio State University, $\dagger$ it was shown that in sorting over a case of eggs, a dozen of the largest ones weighed $301 / 2$ ounces, the medium sized $261 / 2$ ounces, and the small ones $213 / 4$

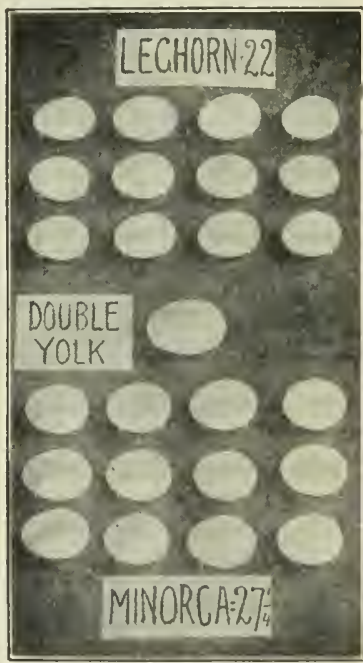

Fig. 194. Notice the difference in size of these eggs. Photograph by courtesy Ohio State University College of Agriculture. ounces. On this basis it was figured that a case of 30 dozens of large eggs would weigh 57 pounds, 3 ounces, while the small ones would weigh but 40 pounds, 12 ounces, an astonishing difference. The Leghorn naturally produces small eggs, and the Minorea large ones, and figures in the bulletin referred to give a

*Poultry Laboratory Guide, 1910, p. 16.

†The Mlarketing of Eggs, April, 1911, p. 16. 
weight of 22 ounces for a dozen of the former, and $271 / 4$ ounces for the latter. The fact is, for the same price, a

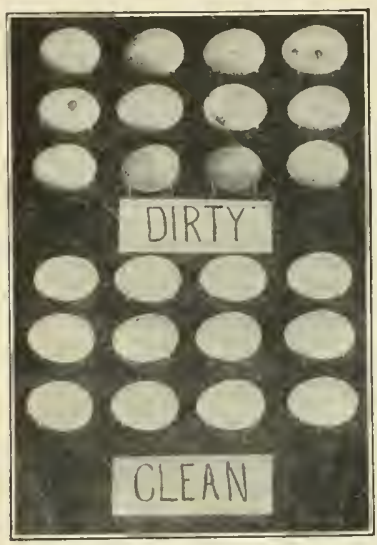

Fig. 195. Clean vs. dirty eggs. Photograph by courtesy Ohio State I'niversity College of Agriculture. dozen large eggs furnish more actual nutrition than a dozen small ones.

The color of the egg is due to a pigment, or coloring substance developed in the shell during the process of formation in the body of the hen. The color is either white or brown. Leghorn and Minorcas produce white eggs, and Brahmas and Plymouth Rocks, brown ones. Some buyers prefer the white color, and others the brown. This is merely a matter of fancy, because there is no difference in the food valuc. When fresh laid, the egg has a clear shell of a beautiful dull glaze, but with age and handling it becomes somewhat glossy or polished and often is soiled.

The degree of freshness of the egg has much to do with its value on the common market. Prime fresh eggs, such as produccrs supply to private consumers, bring the highest price. In a commercial way, eggs are gathered from farmers by hucksters, or are sold to country grocers by the producers. These are placed in

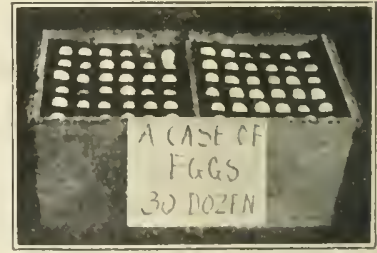

Fiy. 196. A case of eggs. Photograph by courtesy Ohio State Iniversity College of Agriculture. wooden eases holding 30 dozens, and are shipped to the city dealers, where they are graded, and then placed on 
the market. Often the eggs are very poor, especially during the summer season. Eggs from stolen nests, dirty nests, from held over-stock, etc., find their way into the șame case, and form a motley collection. The careful dealer sorts these over, candles them and tries to grade them before placing them on the market.

The grades of eggs on the market differ to a considerable extent, and in some places more than in others. Large markets like New York or Boston handle the most grades. Professor Philips gives the following as an ideal way to grade eggs:*

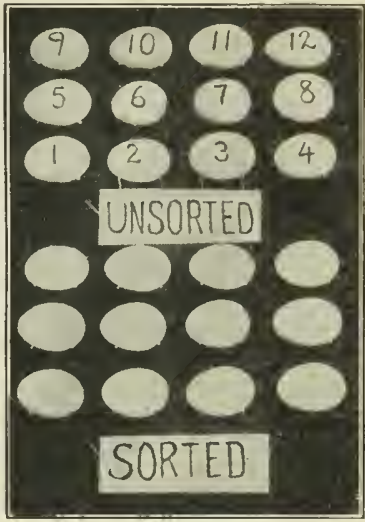

Fig. 197. Sorted vs. unsorted egrs. Photograph by eourtesy Ohio State Univ. ersity College of Agriculture.

Extras. Weigh 28-26 ozs. naturally and absolutely clean; fresl and sound.

No. 1. Weigh 26-2t ozs., sound, fresh, and reasonably clean.

No, 2. Shrunken or stale, washed, small, stained and dirty.

No. 3. Checks-cracked, but not leaking.

No. 4. Rots. Incubator and decomposed eggs.

A Chicago trade paper gave the following grades in July, 1912.

Extras, candled for city trade.............. 22 .

Firsts, graded 70 per cent fresh.......... $171 / 2 \mathrm{c}$.

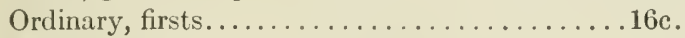

Miscellaneous İots, cases included ..........15c. to $16 \mathrm{c}$.

No. 1 Dirties..................... to $141 / 2 \mathrm{c}$.

Checks.....................

*Bulletin No. 162, Kansas experiment station, p. 251. 
The preservation of eggs during low prices, to sell when they are high, is a common practice. The egg easily spoils under a hot sun or in warm moist weather. Germs of rot develop rapidly in the egg at 55 degrees or higher, consequently it is desirable to keep them below this temperature until they can be used. In cold storage, a temperature of 34 degrees is maintained.

The Storrs experiment station recommends the use of water glass (sodium silicate) for preserving eggs. This is a liquid that sells at about $\$ 1.25$ a gallon. The preserving fluid is made by thoroughly mixing one quart of the water glass in nine quarts of water that has been boiled and cooled. Stone crocks or barrels make good receptacles for preservation. These should be well scalded before using, and then kept in a place where the temperature does not rise above 60 degrees. The best eggs for preservation are those laid in April, May, and early June.

\section{SPECIAL TOPICS FOR STUDY}

1. Compare different parts of the egg.

2. Explain the method of testing eggs.

3. Describe the stage of incubation on the second, eighth, and twelf th days.

4. Describe the methods by which the chick gets out of the egg.

5. Why is moisture necessary during incubation?

6. Describe the ineubator.

7. How should the egg for incubation be selected and cared for?

8. Compare eggs for size and weight.

9. Deseribe Professor Philips' ideal of market grades.

10. Give method for preservation. 


\section{SOME THINGS YOU MIGHT DO}

11. Boil an egg hard for three minutes, and when cold separate into four parts-shell, membrane, white, and yolk.

12. Test some eggs by candling, either from an erg case or from those being incubated.

13. Prepare plans of a brooder, and make one from the plans.

14. Go to a grocery and inspect a quantity of eggs, and report on what you saw as to size, shape, color, and condition.

15. Find market grades and quotations on eggs in at leust three markets. Make comparisons.

16. Bring a sample dozen of your home eggs to school for inspection. 


\section{CHAPTER XXVII \\ THE FEEDING OF POULTRY}

The organs of digestion of the fowl perform their work and have the same influence on the food as do the stomach and intestines of animals. The form of these organs, however, is peculiar to birds. They may be briefly described as follows:

1. The beak, a hard, horny part for breaking, tearing, pulling or picking up food.

2. The mouth and tongue, within and back of the beak.

3. The gullet, a tube which extends to

4. The crop, which lies in front and at the base of the neck. Here the food accumulates and is somewhat softened by digestive fluids.

5. The stomach, where food from the crop is mixed with the gastric juice.

6. The gizzard, a tough muscular organ containing small particles of stone. Here the food is ground to a pulp, mixed with digestive fluid, and then moves on to

7. The intestines, where the last stage of digestion takes place.

The foods suitable for fowls vary widely in kind and character. In fact, farm poultry will eat almost anything that has any nutritive value. So adaptable are fowls to local conditions, that as a rule they are fed the cheapest and most common foods grown in the region in which they are kept. Very naturally, in America corn is most commonly fed, with wheat or its by-products next in favor. In Japan, rice is the food generally used. 'The kind of food, however, should 
vary according to the age and condition of the birds, and the purpose for which they are kept. If for fattening, then a carbonaceous food is best; but if for eggs, then that of a protein nature should be used. As a rule, where grains are fed, those rich in protein are best, for the reason that the fowl applies its food mainly to flesh and egg production, both of which products contain much protein.

The appetite of fowls for different kinds of food is well worth observing. They eat grain or concentrated feed with great relish, and when in confinement this is the kind most used at regular feeding times. However, they are extremely fond of meat, table scraps, tender herbs and grass, the clovers, either green or cured as hay, and of insects, worms, etc. In fact no one class of food seems most relished, and poultrymen generally agree that variety in the diet usually gives the best results, from both the health and the producing point of view.

The special preparation of feed for fowls naturally depends upon conditions. Small particles are usually preferable to large ones. Wheat and other small grains are very satisfactory. Large grains like corn are best cracked or broken. Ground or pulverized feeds, singly or ín mixture, are known as mashes. Wherc no water is used, this food is called dry mash; with water, a wet mash. Clover or alfalfa hay is often thrown into the yard, the fowls readily eating the leaves and delicate parts. The hay also may be cut and mixed with the mash. Young chicks require fine, easily digested food, like oatmeal, cracked wheat, finelygranulated corn, chopped vegetables, etc. Skim milk also is a valuable food for growing chickens.

Green food for fowls causes them to respond very rapidly in increased growth or egg production. Course vegetables are often sliced or chopped into small pieces before feeding, 
although entire cabbages or roots may be hung in the house or fastened to nails on the walls, from which points they will

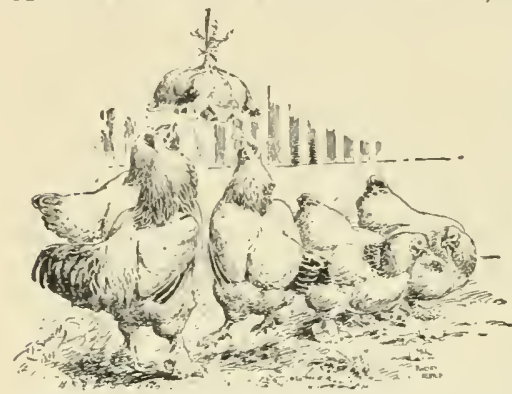

Fig. 198. Fowls eating cabbage suspended just above the head. Reproduced from the "Poultry Manual." be picked to pieces. In recent years sprouted oats have been extensively made use of for feed, especially for young chicks. The common plan is to make a wooden rack-like arrangement, to contain series of shallow pans. The desired amount of oats are taken and put

into a vessel and covered with warm water and let stand over night. The surplus water is then drained off and the oats are spread over the pans to a depth of one-half to threefourths of an inch. The oats should then be placed in a room, preferably a basement or cellar, having a temperature of 60 to 65 degrees. The oats should be sprinkled daily with tepid water, and to provide drainage, the bottom of the pans should be perforated with small holes. In about ten clays the sprouts will be ready to feed to the chickens, and should be used sparingly at the start.

The amount of food necessary for fowls depends entirely upon circumstances, such as the age and

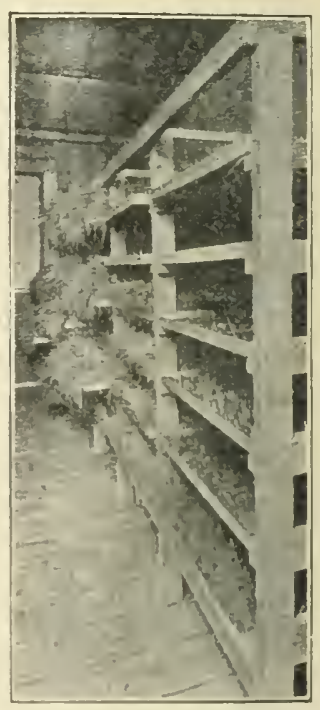

Fiz. 199. liack for sprouting wata, liy courtesy Cyphers Incubator Company. 
kind of fowl, conditions of keep, etc. The best way is to prepare the desired food in given proportions, and then feed as much as will be eaten with a good appetite.

Regularity in feeding fowls is essential. On many farms the poultry must forage for themselves, but under proper

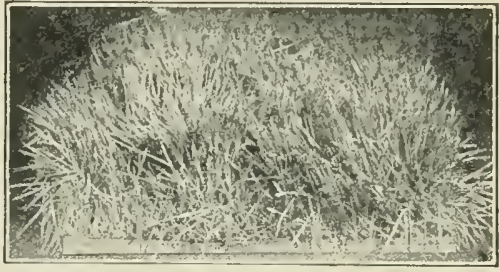

conditions special feeding courtesy Cyphers Incubator Company. By evening.

(u)mon custom is to feed early in the morning; abuut woon, and just before they go to roost. Regularity of feeding also brings the fowls into intimate touch with the poultryman, and enables him to handle them and watch their condition to the best advantage.

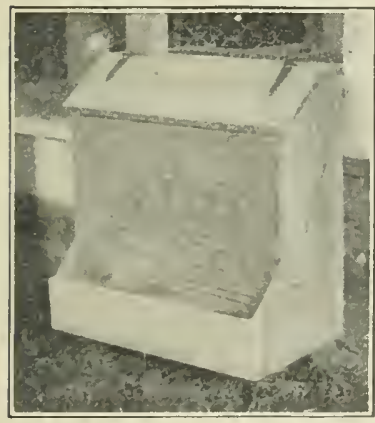

Fig. 201. A feed hopper used at the Obio Strite University College of Agriculture. Photograph from tae University,

is a box-like arrangement containing more or less feed, and from which the fowls can eat frcely at any time. Hopdepends upon the age, condition, and purpose for which they are kept. Young chicks should be fed four or five times daily. The feeding of mature fowls varies among poultrymen, some feeding twice and others three times a day. If one has time to look after the stock in detail, three feeds a day for fowls in limited yards will give better results than will two. Some use what are called "hoppers" or "self feeders." This

Frequency of feeding fowls takes place morning and 
pers are in common use among poultry specialists, and are regarded with favor. Scattering grain in cut straw or floor litter is a good plan, for it keeps the fowls busy and ensures slow eating, both of which habits are desirable. Some feed a mash in the middle of the day, grain being used morning and night. Some prefer one method and some another. The dry mash is a favorite in some places and the wet in others.

The effect of food on the quality of the egg is very noticeable in some cases. Foods of strong odor, such as onions, impart objectionable flavor to eggs. Corn gives a rich

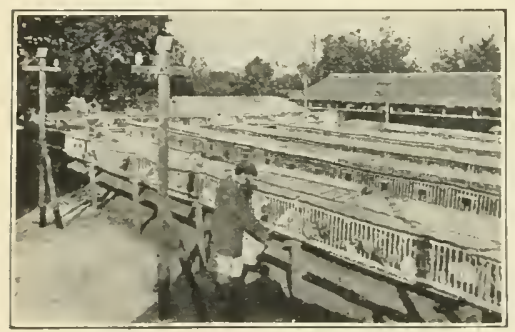

Fig. 202. Forced feeding in England. By courtesy the Poultry Herald. yellow yolk, while most other grains produce less color; Green food and clover or alfalfa hay, also furnish good color to the egg.

Forced feeding of fowls may be done in two ways, one when the feeder simply gives the birds more feed than they need or would eat under natural conditions; the other being a special artificial feeding process known as cramming, wherein the crop is filled with food by the use of a machine, and the fowl fattened as rapidly as possible. Of course what would be a forced feeding of one fowl might not be of another, because of difference in eapacity.

Referring to this subject of forced feeding, Robinson says:* "Forced feeding is almost universal among poultrymen. All regular, good feeding is in a sense foreed feeding. Even under natural conditions, with opportunity to balanee

*Principles and Practice of Poultry Culture. 1911, page 213. 
their own rations, full-fed poultry develop faster and better individually, but at the cost of shorter life and reduction of vitality in the offspring. The poultryman's object is to get as much as possible out of the birds in the shortest possible time; that is, to market as soon as possible those destined primarily for the table, and to keep laying and breeding poultry only as long as they are highly productive. He forces by feeding, but not (intentionally) to the danger point, just as a eareful horseman often drives his horse much faster and farther than the horse would go of its orn accord, yet avoids over-driving."

The use of mineral foods by fowls is even more important than with farm animals. Growth in proportion is really much greater with the fed fowl than the four-footed animal, while the production of eggs requires a considerable amount of mineral matter. The common supply of food does not always furnish enough of the mineral substances, and especially lime, to meet the needs of the fowl. This is particularly true of the laying hen. Consequently some other material must be added, and green ground or broken burned bone, granulated dry bone, and finely broken stone are commonly used to serve this need. Ground or finely broken oyster shells have always been popular for laying hens. As to the exact needs of the body for mineral food, we do not know, but it may be assumed, as based on praetice and the result secured with farm animals, that the mineral substanees play a part in nutrition. Robinson, however, believes that in "good feeding of mixed rations," under range conditions young birds get all the mineral elements they require, and adult birds all they need, except for producing egg shells. He does not think grit is necessary, and since 1902 has fed none to poultry, except in.the first feeds of young ducks and 
geese. Granulated charcoal is frequently used, being regarded as valuable for sour stomach and indigestion and as a blood purifier.

Water for fowls should be clean and pure. Drinking fountains in which clean water may always be found are commendable. Fowls are rather frequent drinkers, and should always have plenty of clean water available. In

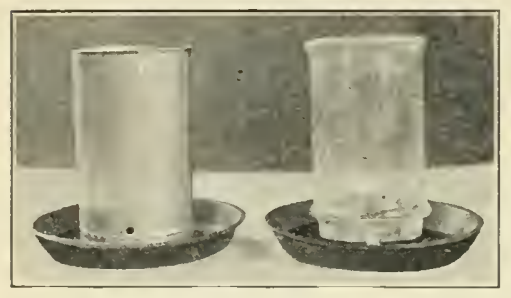

Fig. 203. Two cheaply made drinking fountains. These are jars filled with water and turned with mouths down on pans of water. Photograph from Ohio State University College of Agriculture. winter, care should be taken to see that, water and not ice or snow is supplied. A flock of fifty hens will use from four to six quarts of water a day. Feeding rations for fowls naturally vary, some persons preferring one ration and some another. Most of these here given are easily secured or may be readily prepared, as the foods used in the combinations are grown over a wide extent of country. The rations given are quoted from reports, and so differ in total amounts and in statement of weights or parts. However, the common method is to mix up a quantity of feed, and then use as much as the flock requires.

Rations for young chicks in brooders, used at the Maine experiment station:

Feed for first three days infertile eggs, boiled for one-half hour and then ground up, shell and all, in a meat chopper, and mixed with six times their bulk of rolled oats. Feed with chick grit on the brooder floor. Feed at about 9 A. M. and at $4.30 \mathrm{P}$. M. for the first 21 days. 
On the third or fourth clay, in addition, commence about daylight and at noon, and for five or six weeks feed the following:

Cracked wheat $\ldots \ldots \ldots \ldots \ldots \ldots \ldots \ldots$ parts by weight

Fine oat meal.

Fine cracked corn............... 15

Fine cracked peas............... 3

Broken rice

Chick grit ...

Fine charcoal ................... 2

At about three weeks of age, substitute the following wet mash for the egg-and-oat mixture:

Wheat bran (clean) ............. 2 parts by weight

Corn meal .................... " " " " "

Middlings or red-dog flour. . . . . " " " " " " "

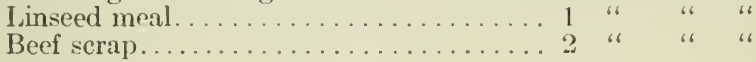

Rations for chicks from birth to maturity, recommended by Professor F. S. Jacoby, Ohio State University.

Grains

No. 1. From 1 st day to 6th week

2 lbs. fine cracked corn

3 lbs. cracked wheat

No. 2. From 6th week to maturity

2 lbs, cracked corn

2 lbs. whole wheat Green foods

Chopped beets

Cut clover or alfalfa

Lettuce leaves Grits

Chick grit

Chick bone

Fine charcoal
Mashes (Dry)

No. 3. From 1st to 21st day

4 lbs. rolled oats

3 lbs. corn meal

3 lbs. wheat middlings

6 lbs. bran

4 lbs. sifted meat scraps

$1 \mathrm{lb}$. alfalfa meal

$1 / 4 \mathrm{lb}$. bone meal

$1 / 4 \mathrm{lb}$. fine charcoal

No. 4. From 21 st day to muturity

$1 \mathrm{lb}$. rolled oats

$1 \mathrm{lb}$. corn meal

$1 \mathrm{lb}$. wheat middlings

2 lbs. bran

$1 \mathrm{lb}$. sifted meat scraps

$1 / 2 \mathrm{lb}$. alfalfa meal

$2 \mathrm{oz}$. fine charcoal

Feed No. 1 ration in litter of cut straw or hay, twice a day, at 7 A. M. and 5 P. M. Feed what the chicks will eat up crean in 15 minutes in the morning, and all they need at night. 
Feed No. 2 ration in open hoppers from the sixth week until the birds are brought into the laying pens in the fall.

Feed No. 3 ration as a crumbly mash, by mixing skimmed milk or buttermilk, three times a day, 9 A.M., 11:30 A. M., and $2: 30$ F. .r. From the first to the third day add chopped, infertile eggs (hard cooked) to the mash in the proportion of 1 part egg to 3 parts mash, also a small quantity of chopped onions, cabbage, or lettuce. After the third day the eggs may be discontinued, and the quantity of regctables slightly increased. Feed in shallow trays 30 inches long, 6

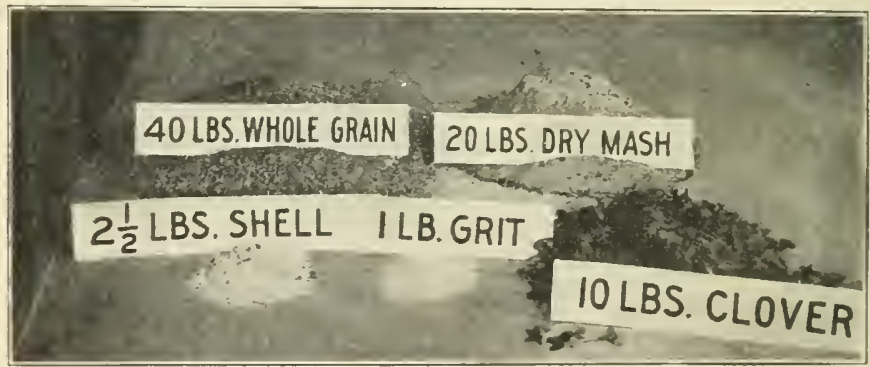

Fig. 201. Ration for mixing. Photograph from Ohio State University College of Agriculture.

inches wide and 2 inches deep. A small quantity of chick grit and granulated bone should be fed in the mash for a few days until the chicks become aceustomed to it, after which they ean be fed in open hoppers. After the fourteenth day, the noon feeding of crumbly mash may be discontinued, and a tray of dry mash left before the chicks at all times. As the chicks become accustomed to the dry mash, the morning and then the afternoon fording of crumbly mash may be discontinued. Feed grem food onre a dily.

Feed No. \& ration dry in open hoppers until the birds are brought to the laying pens in the fall. 
Green food is fed in the crumbly mash twice a day during the first two weeks, and thereafter once a clay in the litter.

Chick grit and bone are fed sparingly in the crumbly mash until the chieks become used to it, after which it can be fed in open hoppers.

Charcoal is fed sparingly in the mash at first, and can later be fed in hoppers, providing the chicks do not over eat of it.

These rations are in some detail, but they are based on careful, practieal study and feeding and give very satisfactory results. Only careful feeding gives the best results in raising chickens.

Rations for laying hens used in different sections of the United States, quoted from various authorities.

(In New York State. G. Arthur Bell, in Farmers' Bulletin 28\%, United States Department of Agriculture.)

200 lbs. cracked corn

360 lbs. wheat

$130 \mathrm{lbs}$. Oats
Fed dry in the litter twice daily.

Also the following dry mash in a hopper:

32 parts corn meal

30 parts meat meal

30 parts ground alfalfa

2 parts oyster shell

1 part grit

1 part charcoal

(In Maine, Bulletin 130, Maine station, page 125.)

Early in the morning, for each 100 hens, four quarts of screened cracked corn are scattered on the litter, whieh is six or eight inches deep. This is not mixed in the litter, the birds doing this thenselves, as they commenee seratching it at once. At $10 \mathrm{~A}$. $\mathrm{m}$. they are fed in the same way two quarts each of wheat and oats. Along one side of the room 
is a feed trough with slatted front. In it is kept the following supply of dry meals thoroughly mixed together:

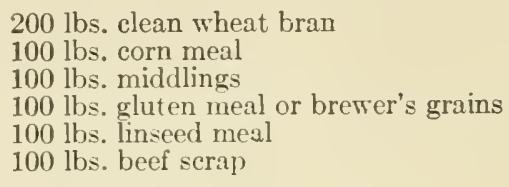

(In Ohio, at Ohio State Lniversity.)

For GRAIN

$15 \mathrm{lbs}$. cracked corn

$10 \mathrm{lbs}$. wheat

5 lbs. heavy oats

Green food, grits and oyster shells

\section{DRY MASH}

4 lbs. corn meal

6 lbs. wheat middlings

4 lbs. bran

4 lbs. meat scraps

$1 \mathrm{lb}$. linseed oil meal

$1 \mathrm{lb}$. alfalfa meal

$1 / 3 \mathrm{lb}$. granulated charcoal

Tablespoonful salt

Feed the grain mixture morning and afternoon in a deep litter of straw. Feed sparingly in the morning, but give the hens all they will eat in the afternoon. Feed the dry mash in a hopper which is open at all times. Keep grit and shell in open hoppers. Feed green food once a day.

\section{(In . Minnesota, Bulletin 119, Minnesota station, page 153.)}

A mash consisting of equal parts of finely ground corn, oats, or shorts, mixed with about 10 per cent of cooked meat, green eut bone, or becf seraps are mixed together dry. Then thoroughly mix with about one-third this bulk of steeped clover leaves or finely eut clover, which has previously been scalded. Another mixture, to be only slightly moistened with water, is the following:

$$
\begin{aligned}
& 2 \text { parts bran } \\
& 1 \text { part wheat shorts } \\
& 1 \text { part ground corn } \\
& 1 \text { part ground oats } \\
& 1 \text { part beef scrays } \\
& \text { 310 part cliarcoal }
\end{aligned}
$$


(In North Carolina, Bulletin 211, North Carolina station, page 54.)

In an experiment extending from December to May, different rations were fed to pens of 10 hens each. The largest production of eggs and the least cost occurred in pens 14 and 15 , fed the following:

$$
\begin{aligned}
& 4 \text { parts corn meal } \\
& 4 \text { parts wheat bran } \\
& 2 \text { parts meat meal } \\
& 2 \text { parts bone meal }
\end{aligned}
$$

Cotton-seed meal was used in three cases. Pens 20 and 22, fed four parts each of corn meal, wheat bran, and cotton seed meal, did very unequal work, one pen laying 225 eggs and the other 378 .

\section{(In Kansas, Bulletin 164, Kansas station, page 290.)}

The following laying ration has been a suecess in feeding White Leghorns and White Plymouth Rocks. Between February 1 and November 1, 1909, one White Plymouth Rock produced 201 eggs and another 196, at a cost for feed of 90 cents each. The Leghorns averaged $166.1 \mathrm{eggs}$ for the same nine months, at a slightly less cost. Following are the rations:

\begin{tabular}{cl}
$\quad$ GRAIN & \multicolumn{1}{c}{ MASH } \\
10 parts wheat & 6 parts wheat shorts \\
10 parts corn & 3 parts bran \\
5 parts oats & 6 parts corn meal \\
& 5 parts beef scrap \\
& 1 part alfalfa meal
\end{tabular}

Fattening ration for fowls. Fowls to be fattened should be kept in a limited enclosure and given but little exercise, and fed a fattening ration. Specialists place chickens in crates and fatten them rapidly for three or four weeks. Professor Jackson of the Pennsylvania station, reporting on fattening in Bulletin No. 107, says: "The common ration of corn meal is rarely as satisfactory as a combination of grains. An excellent mixture is equal parts of finely ground 
corn meal, buckwheat, and oats with the hulls removed. A ration of one to two parts corn meal, one part middlings and five per cent meat scrap may be used if it is not possible to secure the other grains. It is important, whatever grains are used, that they be finely ground. If this ration is mixed with sour milk, no animal food will be needed."

It will be noticed that in all the above rations, corn, wheat, oats, and wheat bran or middlings are the standard foods used. Meat meal or beef scrap, skimmed milk, and clover or alfalfa, are always desirable. In the far West, Kaffir corn or millet seed may be used to advantage. Where barley is commonly grown, this is to be recommended as a feed, and may be used in place of corn if desired.

\section{A REVIEW OF THE SITUATION}

1. Compare the crop and the gizzard.

2. What kind of diet should be given a fow?

3. How of ten should poultry be fell?

4. Explain the meaning of forced feeding, and when it is practiced.

5. Why is mineral matter fed, and under what conditions?

6. Under what conditions should water be supplied?

7. Give the method of feeding young chicks in brooders as used at the Maine station.

8. Give two rations for laying hens used in different states, and the method of feeding.

9. Name the five most common feeding stuffs used.

\section{SOME LITTLE EXPERIMENTS FOR YOUNG PEOPLE}

10. Carefully examine the crop and digestive organs of a chicken.

(a) When taken from a freshly-killed fowl.

(b) Freeze a fowl solid in winter, and with a saw, cut it in two lengthwise and somewhat on one side, to show the digestive organs in plise.

11. Make up two pens of hens, equal in number. Feed one lot a carlonaceous food, like corn; the other a protein food, such as wheat. 
Give some green food, oyster shells, and grits. lieep a record of egg production, and after some weeks report to the school.

12. Make up two pens of hens. Feed alike, except to give one pen oyster shells, and allow none to the other. Keep a record of the number and condition of the eggs, and report.

13. Prepare what you believe to be a good ration of home-grown feeds for growing chickens, and bring a sample to school for inspection and criticism.

14. Report on the rations fed by any two or more poultrymen in the community in whish you live. 


\section{CHAPTER XXVIII}

\section{THE POULTRY HOUSE AND EQUIPMENT}

The need of housing or shelter for fowls varies with the section of the country and the local conditions under which they are kept. While close housing is no longer needed to the extent formerly thought necessary, naturally more protection is required in the colder sections than in the warmer. In winter, in New England, where the ground is usually covered with snow, shelter is a necessity; while in Texas, where snow rarely falls, less protection is required.

The forms and styles of poultry houses differ widely, and no one kind is regarded as the best. A collection of photographs or views of one thousand houses will show a very interesting varicty of style and construction. Years ago buildings were often made of brick or stone, at great expense, and were very warm and almost air tight in winter. In recent years the construction is less expensive, and fresh air properly supplied is an important feature.

Several types of poultry houses, each for a special purpose, are more or less in use in this country. These may be placed in the following classes: (a) Laying pen liouse, (b) fattening house, (e) brooder house, (d) colony house, (e) shelter coop. While plans and details of construction camnot be given in the limited space of this volume, some suggestions of interest and value may be given that are well worth study.

The laying pen house is designed for the purpose of keeping fowls in confincment, in groups suitable for the best results. Yards or runs limit the range of the hens. These houses are permanent of location and as a rule are substantial 
of construction. Formerly they were made with tight walls, had glass windows, and in winter the air within was kept at as comfortable a temperature as possible. Sometimes these houses were lathed and plastered. Not much attention was given to ventilation. Houses of this sort are not built as much as formerly; and if they are, cloth screens on the front or south side replace most of the glass, pure air being

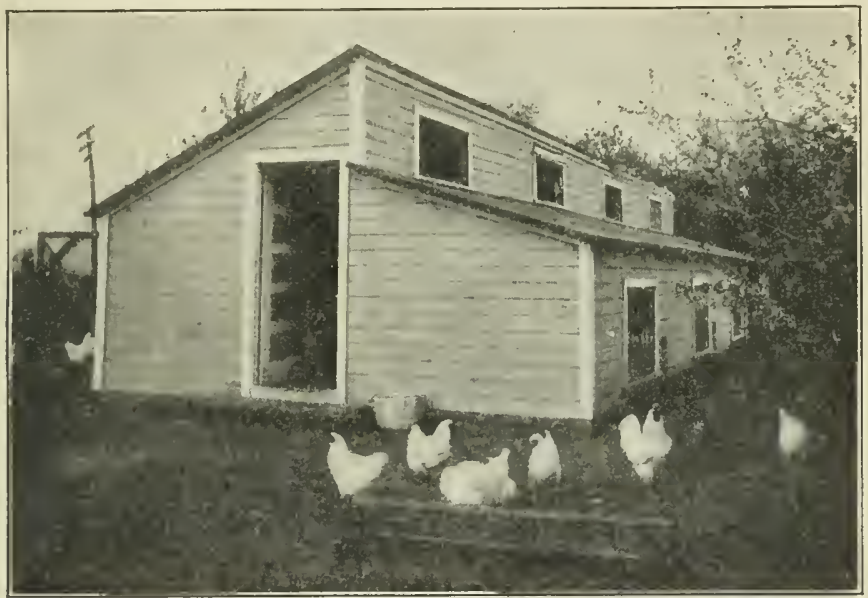

Fig. 205. A continuous house for winter layers. Reproduced from "Poultry Houses."

regarded as a necessity. In many cases, these houses have open front windows, except in the coldest winter weather, when the cloth screens are dropped. Laying pen houses are of different styles, a common one having a simple single pitch shed roof, with a height of 6 or 7 feet at the south, and 4 or 5 feet at the rear. It is best to have the house of a depth that will allow sunshine to reach as near to the back wall as possible. A depth of 14 feet and a width of 12 to 14 feet for 
each pen is a satisfactory size. One should allow 5 square feet for each bird in such a house. In a house of this sort

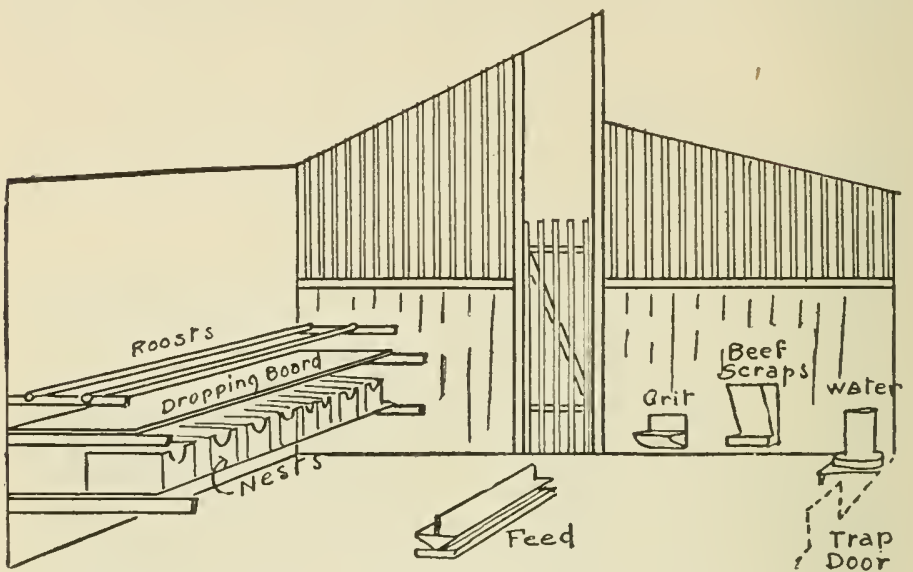

Fig. 206. Arrangement of interior of poultry house shown in Fig. 205.

the floor should be made of concrete in order to make it rat proof and to keep it dry. This floor may be covered with eut straw or ehaff, and be used in cold weather as a scratching shed. The walls should be tight enough to prevent drafts.

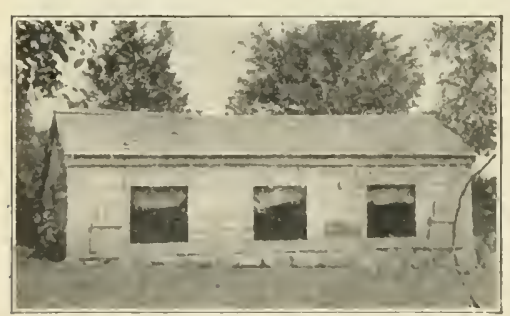

Fig. 207. A cheap laying house. Photosraph by courtesy the P'oultry Herale. The roosts may be placed just above a low platform at the rear or on one side, below which are the nests. In front, plenty of window space should be provided, which should be covered with poultry wire netting, and also have cotton eloth seceens, to be dropperl during very cold weather. Doors of stanclard size are usually placed at one or both ends of the house, 
with wire doors in the partitions, to allow passage through the various pens. In houses containing many pens, doors are sometimes provided to give entrance from the pens into the yards.

The fattening house is a small structure containing crates in which fowls are fattened, arranged along each side of a passage way. The house is simple of construction, and has superior ventilation with inferior light, as fowls are best fattened under conditions of subdued light. Fattening crates are in tiers, with feeding trays in front of each, which with other conditions provide for the least amount of labor in caring for the birds. Houses of this kind are not common on American farms, but are used especially by men who make a business of fattening fowls for market.

The brooder house is for the purpose of sheltering young chickens under conditions of uniform heat,

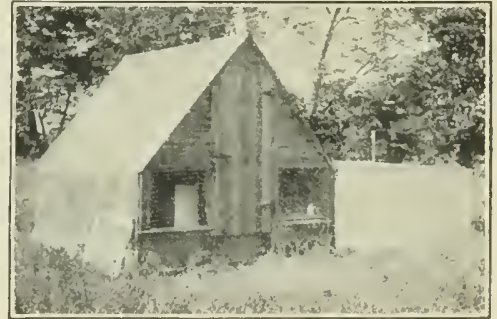

Fig. 20S. A colony house and brooder. Photograph by courtesy Prof. F. S. Jacoby. giving them protection under what are called "hovers," comparable with the shelter under the mother's wing. A brooder house may be a simple box-like affair of one room 6 by 8 feet in size, with the hover in the back and a door and window in front. The hover is round, about 3 feet in diameter, and resembles a pan turned upside down, except that its sides are made of cloth, which is slashed at the edges. Warm air is conducted into the hover, and here the young chicks gather, as under a mother's wing. The small brooder house thas either a kerosene or gasoline lamp attachment, by which the necessary 
warm air is supplied. On large poultry farms, the brooder house may be of consiclerable size, containing a series of pens,

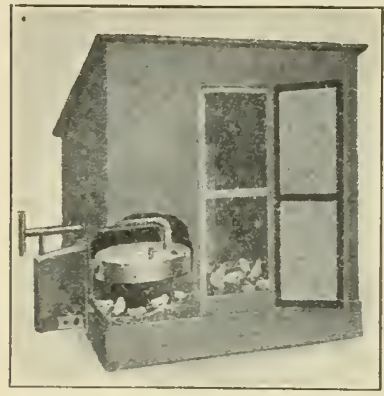

Fig. 209. A portable colony house and hover. By courtesy
The Cyphers Incubator Company. in the end of each of which is a hover, warm air being supplied by a hot water heating plant located in one end of the building. Brooder houses should be well lighted, warm and dry, and rat proof.

The colony house is a small, single-room building containing roosts and nests, and located in a yard or field. It is simple and cheap of construction, and is usually portable, so as to be easily moved from place to place. There is no one style of house; and structures are made of all kinds of material, ranging from piano boxes, at a total cost of 3 or 4 dollars, up to those made with care by a carpenter, costing

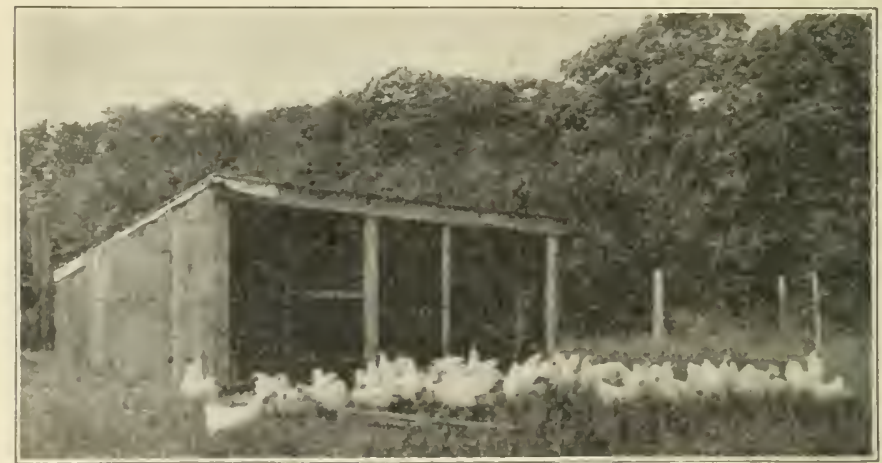

Hig. 210. A cheap, open-front colony house. lhotograph by cuuresy tho Poultry Herald. 
$\$ 35$ or $\$ 40$. A fairly good type of colony house has both a door and window in front, the latter being covered with wire screening, and with a curtain to be used for cold weather proteetion. A small window in one end, for both ventilation and light, and a wooden floor are also desirable features. Poultrymen having houses differing widely in style of construction and lighting seem to get equally good results from their fowls. Two strong arguments in behalf of the colony house

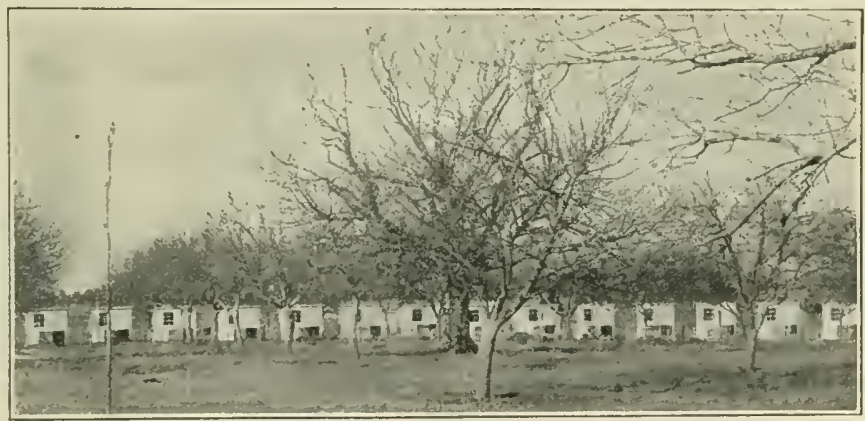

Fig. 211. A large colony house system. Photograph by courtesy the Poultry Herald.

are, a flock of about the right size may be kept in a yard of suitable area; also the house may be shifted from time to time to new and clean soil conditions, thus providing good, permanent sanitation. Colony houses may be hauled into grain fields after the harvest, where the fowls secure uncommonly good forage of grain and inseets.

The shelter coop is usually built for a hen and a brood of chickens. It varies much in construetion. Common boxes 2 or 3 feet square, with slat or wire front; empty barrels, with a slat attachment at one end; and shelters of tent or $A$ shape, are frequently seen. These eoops 
should be made so as to enable the chicks to pass freely in and out, to give the hens dry and comfortable shelter, and to protect the chicks at night from rats and other vermin.

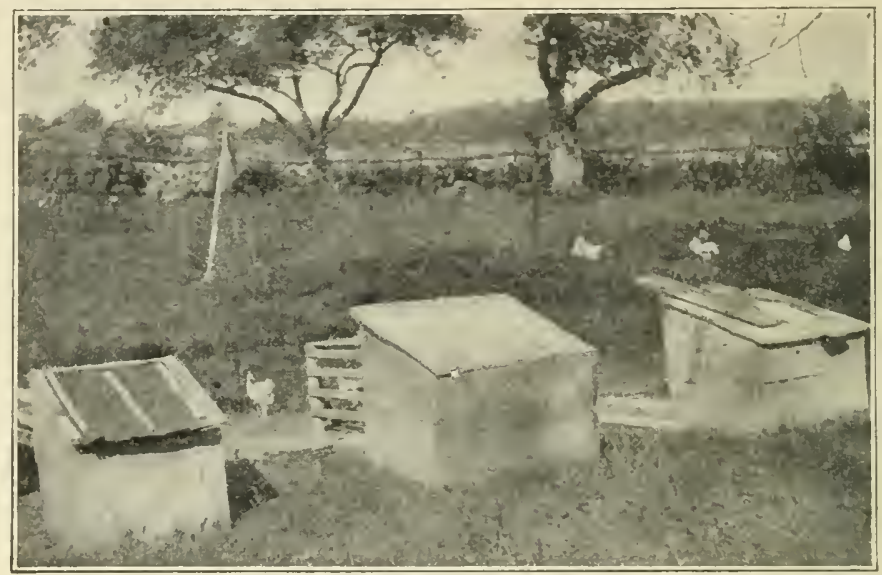

Fig. 212. Shelter coops. Photograph by courtesy the Poullry Herald.

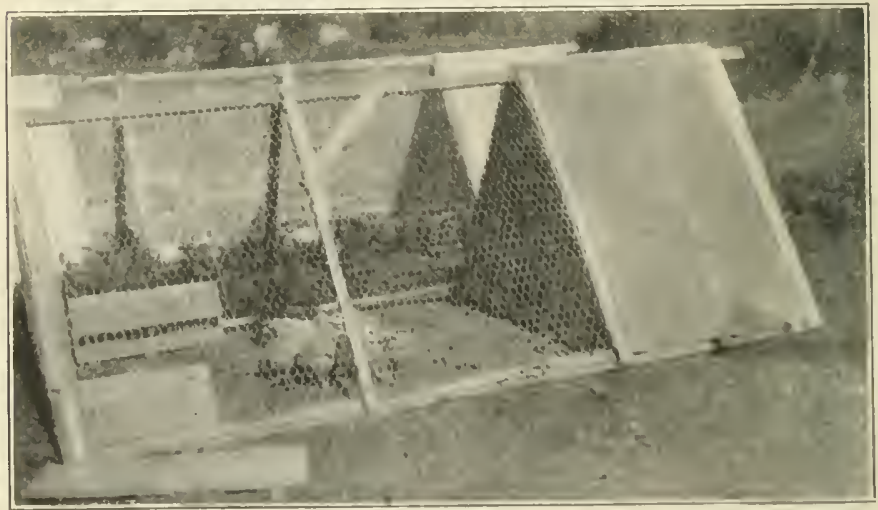

Fig. 213. An A-shaped sheller ronp. Photograph by courtesy Ohio state Iniversity College of Agrieulture. 
The location and construction of the poultry house require careful thought, if the most satisfactory results are to be secured. Therefore a few suggestions, rather general of application, are here given.

The site of the poultry building should be where drainage is good and the soil naturally dry. Further, the elevation should be sufficient for a good circulation of air. Under damp conditions throat or lung trouble is very likely to occur. In damp soil of a clayey or loamy nature, intestinal

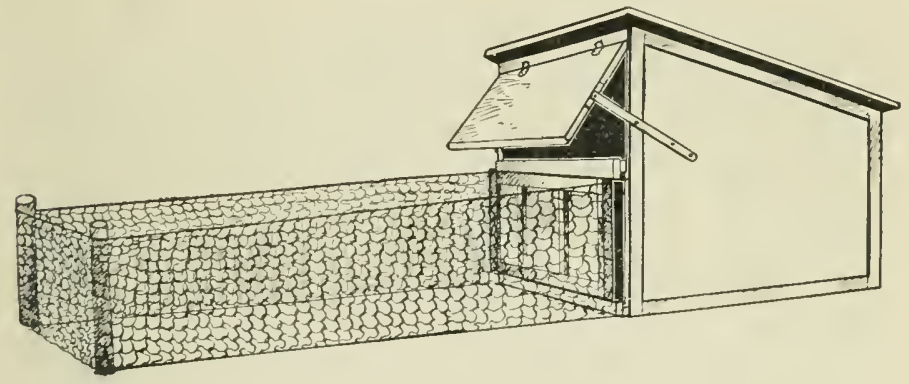

Fig. 214. A brood coop and yards. Reproduced from "Poultry Houses."

and other parasites that affect poultry breed more freely than elsewhere. A dry location promotes clean bodies and feet, which mean the production of clean eggs.

The size of the poultry house should depend upon the number of fowls one wishes to keep. On most farms large flocks do not give as satisfactory returns as small ones. With a flock of 50, each bird should be allowed 5 square feet of room. With larger flocks not quite so much space per fowl will be required. One can obtain satisfactory returns with 100 fowls of the smaller breeds in a house 20 by 20 feet floor space. If fowls are crowded, good results in egg production can not be expected. 
The width of the poultry house depends upon size of the flock. Under most conditions, a house 14 or 16 feet wide gives an ample depth for each pen. One should plan to use standard lengths of timber, so that as little waste as possible will occur in sawing.

The foundation of the poultry house should be of concrete or stone, if intended for a permanent laying house. This foundation should be deep enough in the ground not to be affected by the action of frost, and should rise 6 to 12 inches above the surface. The thickness of wall will depend on local conditions, ranging from 8 to 12 inches. Portable colony houses may be built on $4 \times 4$ runners. Halpin and Ocock, of Wisconsin University, recommend the use of "two small trees of some durable wood which may be flattened off on top and tapered off at bothends so as to make a satisfactory runner."

The walls of the poultry houses are built of wood, brick, concrete, or stone. The most common method is to use $2 \times 4$ studs nailed to $2 \mathrm{x} 6$ sills. On the outside of the studs is fastened a layer of strong tarred paper, over which matehed siding is nailed horizontally. When well put together this makes a wall free from drafts and very satisfactory. If rough boards are used, battens or strips should be tacked over any cracks. It is not desirable to place siding over the studs on the inside, for in that case rats and mice will find a place for hiding. A wooklen wall in winter is most satisfactory, as solid concrete or stone may be moist or frosty under some conditions. Concrete or brick walls that are partly hollow are preferable to the solid wall.

The roof of the poultry house should be strong, simple and comparatively inexpensive. A straight lean-to or one-slant roof is most common and can be built with least cost. If the house is over 14 feet wide, the usual $2 x+$ rafters should be 
supported. A combination roof has a double pitch, having a short pitch in front and a long one bchind. This type of roof is well suited to buildings wider than 14 feet, and gives a strong construction. A two-pitch or gable-roof house usually has rafters of the same length, coming to a riclge in the center. 'This gives a high center to the pen, hence a loss of heat, so that in winter the house is likely to be cold. A ceiling is sometimes built in such a house, and attic storagc room thus provided. What is called the monitor roof, has

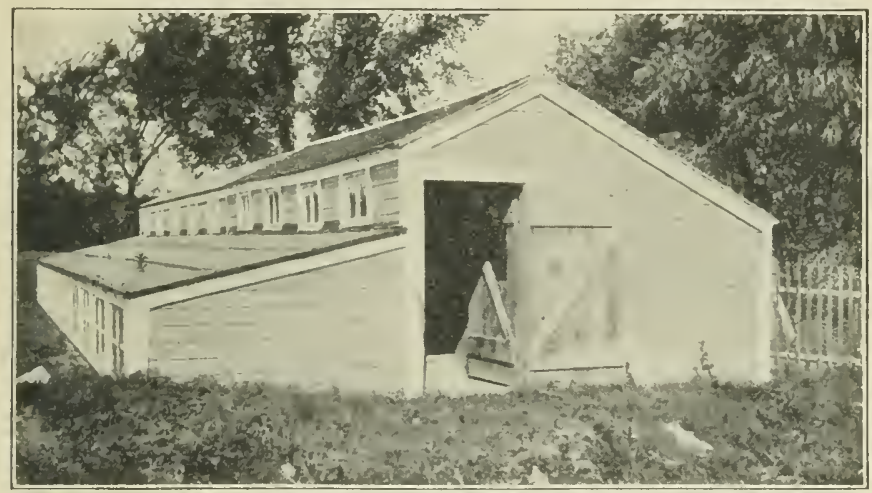

Fig. 215. A continuous poultry house with raised alley. Photograph by courtcsy the Poultry Herald.

what resembles a continuous cupola along its whole length, with adjustable windows in the south side, by which sunlight may reach the rear inside. A semi-monitor roof has one long sweep of rafter for perhaps two-thirds the width of the house. Below the high point of rafter a vertical wall is drepped sufficiently to allow a line of windows. From the bottom of the window sill, a shorter length of rafter gives the necessary front pitch to the roof. There are also houses with the fronts slanting to the ground, and others of wood that 
have roofs of the tent form, with no side walls in front or behind. A roof covering of rough boards and asphalt or tarred composition paper of some sort, gives good satisfaction. Wooden shingles in most localities are too expensive, and in the colder sections shingle roofs are too drafty and cold in winter.

The floor of the poultry house should be of concrete in the permanent house; but in the colony house, one of matched

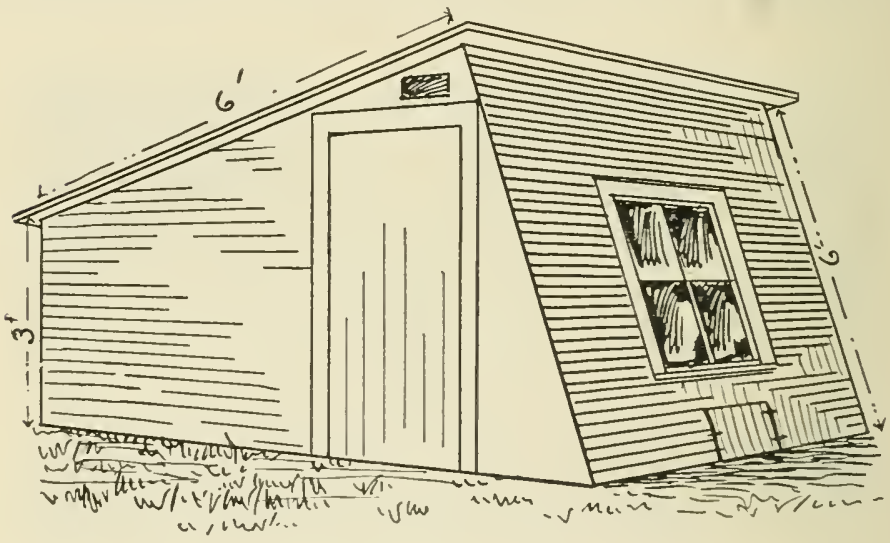

Fig. 216. A slant-roof colony house. Reproduced from "Poultry Houses."

flooring is best. Every effort should be made to keep the floor dry, and to prevent the harboring of rats or other ver$\min$.

Partition material in the poultry house should usually be of wire netting. If the house is long, a close wooklen partition at intervals is desirable, in order to strengthen the building, and also to prevent drafts. A house having six pens might have one solid eentral partition, and the others of wire.

The windows of the poultry house should be arljusted to local conditions. In the Southern states, glass should be 
unnecessary. In the colder North, an arrangement by which one sliding glass window ean be arranged in eonneetion with eloth-screened openings, will give the best satisfaction. The windows should have a covering of wire screening, with eurtains that are to be used only in severe weather. Some men, in faet, keep permanent open fronts in their houses, never using glass or eloth sereen, and do not consider that their birds suffer from eold at any time.

Perches should be in the warmer part of the pen, free from drafts, and not high above the floor. The perehes should be 12 inehes apart, and not nearer the wall than 15 inches. They should be fastened together in a frame and hinged to the wall, being supported level with standards, or legs. It is a good plan to have a board platform a few inches below the perch, on which the droppings may be eaught. The perches may be raised as desired, and the droppings removed. Perehes of $2 \mathrm{x} 4$ pieees, on edge, with rounded eorners are recommended.

The nests should be against the wall, and be 12 or 14 inches square, aecording to the size of fowl. Nests are sometimes placed below the dropping board, the hens entering from the back and the eggs being removed from the front by means of a hinged door. These nests are rather dark, which is an advantage, for hens under such conditions rarely eat their eggs. Open nests may be fastened to the side of the pen if clesired, a eommon method. Trap nests are used in many houses today. The prineiple of this nest is that when the hen enters, she springs a trap door, and so is confined until released by the poultryman. Thus he knows just what hens lay each day, and makes a reeord of the same. Hens laying in trap nests usually are nambered with a metal leg band. 
A dust bath in the poultry house is most important. The process of dusting is the method by which the bird keeps herself free from lice and similar pests. Many poultrymen have a corner of the pen arranged so that road dust, sifted coal ashes, or dry sand may be put there for dusting. A depth of 3 or 4 inches is sufficient.

\section{IF YOU HAD THE "CHICKEN FEVER," COULD YOU}

1. Describe the important features of the laying house?

2. Explain the purpose of the fattening house?

3. Describe a hover and its use?

4. Tell of the construction and value of the colony house?

5. Compare a good and a bad site for poultry buildings?

6. Figure out the size of house you might need, and tell why?

7. Compare the single- and the double-pitch roof?

8. Discuss the subject of window covering?

9. Instruct in the essentials of perch construction?

10. Tell where to place the nests and the size they should be made?

\section{SOME INTERESTING THINGS TO BRING TO SCHOOL}

11. A picture of the poultry yard at home, showing baildings.

12. A picture of the best poultry building you know of in the vicinity.

13. A drawing showing cross-section eonstruction of some poultry house of which you know.

14. A report on the roost arrangement in five different poultry buildings.

15. A report on the location of a few poultry yards on different farms.

16. A statement of the number of farmers in the vicinity who keep chickens but have no special poultry houses for them. 


\section{APPENDIX}

\section{TABLE A}

Dry matter and digestible nutrients in some common feeding stuffs. (Total pounds in 100 of feed.)

\begin{tabular}{|c|c|c|c|c|}
\hline Find of feed. & Dry matter. & Protein. & $\begin{array}{l}\text { Carbohy- } \\
\text { drates. }\end{array}$ & Fat \\
\hline Corn.............. & 89.4 & 7.8 & 66.8 & 4.3 \\
\hline Corn-and-cob ineal . . . & 84.9 & 4.4 & 60.0 & 2.9 \\
\hline 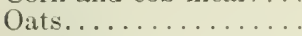 & 89.6 & 8.8 & 49.2 & 4.3 \\
\hline Soy beans . . . . . . . & 88.3 & 29.1 & 23.3 & 14.6 \\
\hline Gluten feed....... & 90.8 & 21.3 & 52.8 & 2.9 \\
\hline Wheat Bran......... & 88.1 & 11.9 & 42.0 & 2.5 \\
\hline Cotton-seed meal. ..... & 93.0 & 37.6 & 21.4 & 9.6 \\
\hline Linseed meal. ......... & 90.2 & 30.2 & 32.0 & 6.9 \\
\hline Corn fodder, green.... & 20.7 & 1.0 & 11.9 & 0.4 \\
\hline Corn stover, field cured. & 59.5 & 1.4 & 31.2 & 0.7 \\
\hline Corn silage.......... & 26.4 & 1.4 & 14.2 & 0.7 \\
\hline Alfalfa, green......... & 28.2 & 3.6 & 12.1 & 0.4 \\
\hline Timothy hay.... & 86.8 & 2.8 & 42.4 & 1.3 \\
\hline Red clover hay.......... & 84.7 & 7.1 & 37.8 & 1.8 \\
\hline Alfalfa hay.......... & 91.9 & 10.5 & 40.5 & 0.9 \\
\hline Cow pea hay ......... & 89.5 & 9.2 & 39.3 & 1.3 \\
\hline Turnips (flat)..... & 9.9 & 0.9 & 6.4 & 0.1 \\
\hline Mangel-wurzel $\ldots .$. & 9.1 & 1.0 & 5.5 & 0.2 \\
\hline Tankage............ & 93.0 & 50.1 & 0.0 & 11.6 \\
\hline Skim milk (separator) & 9.4 & 2.9 & 5.3 & 0.3 \\
\hline
\end{tabular}

Note: The above table is compiled from "Feeds and Feeding," by Professor IW. A. Henry, 1912 edition. This volume contains analyses of all feeding stuff in use in an important degree on American farms.

\section{A TABLE OF FEEDING STANDARDS}

The following are a number of standards that have been arranged from Wolff's feeding tables, and are given simply for the purpose of enabling the pupil to work out a few easy problems in feeding. Suppose you know of some one having a cow that is producing about 22 pounds of milk a day. If the owner is using feeds that are giren in Table $A$, then with the aid of that table and this, you should be able to figure out whether or not the eow is being fed right. In these standards, each 1000 pounds of the animal's weight 
requires daily the amount of dry matter and digestible nutrients specified. These standards are not for growing, young animals, but for the more mature, or those being fattened. Wolff, however, does give standards for the different kinds of young growing animals. In using this table add or deduct the dry matter and nutrients necessary, according to the weight of animal.

TABLE B

Total dry matter and digestible nutrients required per day per $1000 \mathrm{lbs}$.

\begin{tabular}{|c|c|c|c|c|c|}
\hline \multirow[b]{2}{*}{ Animal and purpose } & \multirow{2}{*}{$\begin{array}{l}\text { Dry } \\
\text { matter }\end{array}$} & \multicolumn{3}{|c|}{ Digestible nutrients } & \multirow{2}{*}{$\begin{array}{l}\text { Nutritive } \\
\text { ratio }\end{array}$} \\
\hline & & Protein & $\begin{array}{l}\text { Carbohy- } \\
\text { drates }\end{array}$ & Fat & \\
\hline Horse at medium work & 24 & 2.0 & 11.0 & 0.6 & $1: 6.2$ \\
\hline Horse at heavy work & 26 & $2 . \overline{5}$ & 13.3 & 0.8 & $1: 6.0$ \\
\hline Cattle, partly fattened & 30 & 3.0 & 14.5 & 0.7 & $1: 5.4$ \\
\hline Cattle, nearly fattened & 26 & 2.7 & 15.0 & 0.7 & $1: 6.2$ \\
\hline $\begin{array}{l}\text { Mileh cow, (daily yield, } \\
11 \text { lbs. milk) .... }\end{array}$ & 25 & 1.6 & 10.0 & 0.3 & $1: 6 . \overrightarrow{7}$ \\
\hline $\begin{array}{r}\text { Milch cow, (daily yield, } \\
22 \text { lbs, milk)...... }\end{array}$ & 29 & 2.5 & 13.0 & 0.5 & $1: 5.7$ \\
\hline $\begin{array}{l}\text { Eres, with lambs..... } \\
\text { sheep, fattening, last }\end{array}$ & 25 & 2.9 & 15.0 & 0.5 & $1: 5.6$ \\
\hline part of period. . . . & 25 & 3.5 & 14.5 & 0.6 & $1: 4.5$ \\
\hline $\begin{array}{l}\text { Brood sows........... } \\
\text { Hogs, fattening, first }\end{array}$ & 22 & 2.5 & 15.5 & 0.4 & $1: 6.6$ \\
\hline $\begin{array}{l}\text { part of period.... } \\
\text { Hogs fattening in last }\end{array}$ & 36 & 4.5 & 25.0 & 0.7 & $1: 5.9$ \\
\hline part of period... & 2.7 & 2.7 & 18.0 & 0.4 & 1.7 .0 \\
\hline
\end{tabular}




\section{INDEX}

Aberdeen Angus cattle, 55; characteristics of, 57; early breeders of, 56 ; importation into America, 56; origin, 56. Action, study of in horses, 164, 170.

Age, of horses, 147; sheep, 198. Alfalfa, 295.

American Saddle Horse, 28.

American Trotter or Pacer, 30, 226; famous records, 31; famous trotters and pacers, 32 ; origin of the, 30 .

Angora goat, 95.

Animal husbandry, importance of. 11.

Animals, care of, 313 ; compared with plants, 263 ; composition of, 257; food requirements of, 276,321 ; market classes and grades, 119; types, 114.

Armsby feeding standards, 279, 286.

Arab horse, 26.

Ash, in plants and animals, 2.58, 262 ; in food, 269.

Ass, 43.

Atavism, 227.

Ayrshire cattle, 68: cliaracteristics, 69 ; distribution, 70 : origin, 68; records, 70 .

Bacon hog type, 119, 218.

Bantam fowls, 333 .

Bakewell, Robert, 90, 232.

Balanced ration, defined, 279 ; how to calculate, 281.

Barley, 293, 308.

Bates, Thomas, 48, 223, 224.

Beef, cuts of, 174 ; production, 16.
Beef animal, condition of the, 176 ; form of the, 174 ; quality in the, 177 .

Beef cattle, breeds, 4i: judging, 174; score card for, 178 ; type, 117, 122.

Beigian horse, 41.

Bellfounder, 226.

Bermuda grass, 291.

Berkshire pig, characteristics, 101; distribution, 102; origin, 100.

Black Faced Highland. sheep, 94.

Booth, William, 49, 224.

Brahma fowls, 330 .

Bran, 306.

Branding, 254.

Bieeders, young, suggestions to, 248.

Breeding, chapters on, 221; exercise of breerling stock, 320 ; importance of heredity in, 223 ; judging breeding animals, 182, 207, 217.

Biewers' grains, 308 .

Brome grass, 291.

Brooder, 353.

Brooder house, 377.

Brown Swiss cattle, 71

Bull. care of, 321; dairy, form of the, 184.

Byerly Turk, 27.

Calorie, 270.

Calorimeter, 271.

Canada field pea, 297.

Carbohydrates, 259, 263, 268.

Care of farm animals, 313.

Carriage horse, breeds, 33: judging,.158; score card for. $160 ;$ type, 116. 
Carrot, 301.

Cattle, breeds of, 46; food required by, 279, 322; judging, 125,173 ; marliet classes and grades, 119; stomach of, 265 ; origin, 46 ; type, 117 .

Cereals, as forage, 292 ; as concentrated feeds, 304 .

Channel Islands, 58, 66, 129.

C'ieshire pig, 111.

Chester White pig, 106: characteristics, 107: origin, 106.

Cheviot sheep, 87.

Clover, 294.

Clydesdale horse, 39; merits, 39: distribution. 40.

Coach horse type, 116.

Coarse feeds, 288 .

Cochin fowls, 331 .

Cocked ankle, 156.

Colling Bros., $48,224$.

Colony houses for poultry, $37 \mathrm{~s}$.

Color, in inheritance, 225.

Comparison, judging by, 134 .

Composition of plants and animals, 257 .

Concentrate, defined, 260.

Concentrated feeds, 303 .

Conformation, definition of, 125 .

Coops for poultry, 379.

Corn, 292, 304.

Cotswold sheep, 91.

Cottonseed-meal, 309.

Cuw pea, 297.

Cross-bred animal, defined. 240.

(ruickshank, Amos, 49, 224.

Curb, 152.

Dairy bull, form of the, 184 , quality in the, 184 ; temperament, 185 .

Dairy cattle, breeds of, 5s: judging, 183; points of, 187; score card, 1S6; type, 117.

J)airy cow, form, 1S3; quality in the, 184; size of the, 183; temperament, 185.

Darley Arabian, 27.
Delaine Merino, 77, 203; score card for, 205.

Denmark, 29.

Deron cattle, 70

Dexter cattle, 72.

Digestible nutrients, amounts in food, 274; tables of, 287.

Digestion, process of, 265 .

Digestive organs, capacity of, 267.

Distillers' grains, 310 .

Dorset Horn sheep, $\mathrm{S} 6$; score card for, 130.

Draft horse, breeds of, 36 ; judging of, 167; score card, 168; type, 116.

Dual-purpose cattle type, 117.

Dncks, breeds of, 334 .

Duroc-Jersey pig, 104, merits of the, 105.

Ditch Belted cattle, 72.

Eclipse, 27.

Eggs, color of, 356; effect of food on, 364; freshness of, 356 ; grades, 357: incubation. 350 ; judging, 346 ; parts of, 349 ; preservation of, 358 ; size and weight of, 355 ; testing, 350.

Ellman, John, 79.

Environment and selection, 235.

Essex pig, 112.

Exercise, need of for farm animals, 320 .

Farm Animals, care of. 313: food required by, 321: inportance of, 11; judging of. 125. 173: market classes and grades, 119; types of, 114: uses of, 14 .

Fat, in animals, 262: in food. 269 ; in plants, 260 .

Fecundity, 225.

Feeding standards, 27t; Wolff's, 277; Armsby's, 279; Haecker's, 285. 
Feeding tables, 287, 288.

Feeds, coarse, 288; concentrated, 303.

Feet, care of, of farm animals, 323 ; inspection of, 162 .

Food constituents, 260, 268 .

Foods, heat value of, 270 ; influence of a body, 265; required by animals, $321,276$.

Forage, 288.

Fiunder, 155.

French Canadian cattle. 72.

French Coach horse, 35.

Gaits of horses, 29, 34, 146, 164 .

Galliers, Wm., 53.

Galloway cattle, $5 \overline{6}$.

Geese, breeds of, 337.

Genetics, 235.

Gelman Coach hors: 36.

Gluten feed, $30 \%$.

Goats, 95.

Godolphin Barb, 27.

Grade animal, defined, 240

Grasses, kinds and values for feed, 288.

Guernsey cattle, 66; characteristics, 66; distribution, 68; origin, 66 ; records, 67 .

Hackney horse. 33.

Haecker's feeding standards, 285.

Hambletonian 10, 30, 226.

Hampshire Down sheep, 85.

Hampshire pig, 109.

Heaves, 151.

Heredity, defined, 221; latent characters, 227.

Hereford cattle, 52; early breeders of, 53 ; importation into America, 53.

Herd records, 252.

Herod, 27.

Hewer, John, 53.

Hegs, (See Swine).
Holstein-Friesian cattle, 62; bleed characteristics, 62 ; distribution, 64 ; origin, 62 ; records, 64 ; types, 65.

Hominy feed, 305 .

Horses, age of, 147; breeds of, 23 ; development of breeds, 26 ; domestication of, 25 : food required by, 278, 321; judging, 125, 158; origin of. 23 ; points of, 138 ; types of. 116 ; unsoundnesses, 151.

Incubation, 349 .

Indian corn, 292, 304.

Inheritance, forms of, 224 (See Heredity).

Irish Grazier pig, 102.

Jacoba, Irene, 61.

Jersey cattle, 58; breed characteristics, 60; distribution. 59; origin, 58; records, 60 . Judge, description of a good, 125.

Judging, reasons and methods, 125; horses, 158 ; cattle, 173 ; poultry, 340 ; sheep, 196: eggs, 345; swine, 209; pedi gree, 245 .

Kentucky blue grass, 289 .

Kerry cattle, 72 .

Langshan fowIs, 331 .

Large Yorkshire pig, 108.

Leghorn fowls, 331.

Legumes, 294.

Leicester sheep, 90 .

Lincoln sheep, 93.

Linseed oil meal, 30 ?.

Live stock, importance of, 11: market classes and grades 119; principal markets, 122; shelter for; 316 ; stalls for 319. 
Iaintenance ration, 277 .

Maltese goat, 96 .

Mangel, 300.

Manures, 19.

Market grades, cattle, 119; eggs, 357 .

Marking of animals, 253.

Matchem, 27.

Ieat meal, 311.

Merino sheep, 75, 235.

Nerino type, 118, 123, 203.

Messenger, 30 .

Middlings, 307 .

Milk, 311.

Milk production, in inheritance, 225.

Milk veins, 194.

Milch goats, 96 .

Millet, 291.

Minorca fowls, 332.

Mohair, 95.

Mule, 44.

Mule Foot hog, 226.

Mutation, 227.

Natural selection, 230.

Navicular disease, 156.

Nutritive ratio, 272.

Oats, 293, 307.

O. I. C. pig, 106.

Oil meal, 309.

"Old Grannie," 56.

Orchard grass, 290.

Orpington fowls, 330 .

Oxford Down sheep, 83.

Palatability, 271.

Pedigrees, ancestry in, 243; chapter on, 240; bracket form of, 241; line of female descent pedigree, 242 ; merit value of, 244 ; score card for, 245 ; selection of, 238 .

Pig (See Swine).

Plants, composition of, 258; compare with animals, 263.

Plymouth Rock fowls, 328.
Poland-China pig, 102.

Pony, wild, 25; Shetland, 43; type, 117 .

Poultry, dust bath for, 386; eggs and incubation, 352 ; feeding, 360 ; houses and equipment, 374 ; judging, 340 ; organs of digestion of, 360 ; types and breeds, 325 .

Prepotency, 222.

Price, John, 53.

Protein, animal, 262; in food, 268; in plants, 259.

Quarter-crack, 155.

Rambouillet sheep, 78, 203.

Rape, 299.

Ratio, nutritive, 272.

Fations, balanced, 279: calculating, 2s1; maintenance, 277 ; poultry, 366 .

Red clover, 294

Red Polled cattle, 70.

Red top, 290.

Registration of animals. 253.

Rhode Island Red fow's, 329.

Ringbone, 154 .

Roaring, 151.

Romney Marsh sheep, 94 .

Root crops, 300 .

Rothamsted Experiment Station, 20.

Roughage, 260, 288.

Rye, 293, 309.

Saanan goat, 97 .

Salvator, 28.

Sanitation of stables, 315 .

Score card, for beef cattle, 178; carriage horse, 160; dairy cows, 186; draft horse, 168: eggs, 346 ; origin of, 129; pedigree, 245; poultry, 344 ; sheep, 201, 205; swine, 212; use of, 129. 
Selection, 230; artificial, 231; environment and, 235; methodical, 231 ; natural, 230 ; policy in, 230 ; to secure desirable characters by, 233; rational selection, 237.

Self-feeders, poultry, 363 .

Snetland pony, 43.

Shorthorn cattle, 47; characteristics of, 51; distribution, 50 ; improvement of, 48.

Sheep, age, 198; breeds of, 74 ; classes of, 74 ; food requirements, 322; handling, 196; judging, 196; origin of, 74 ; pens for, 320; score card, 201, 205 ; types of, 118, 203.

Shire horse, 40.

Short leet, 135.

Shorts, 307.

Shropshire sheep, 82.

Side bone, 153.

Silage, 298.

Small Yorkshire pig, 112.

Soil fertility, relation of farm animals to, 18 .

Southdown sheep, 79 .

Soy bean, 297.

Spavin, 152, 153 .

Speed, inheritance of, 226.

Splint, 155.

Stables, 315.

Standard Bred trotters, 30.

Standard of Perfection, 340.

Steers, open shed feeding, 318 .

Stock farming, 21.

Suffolk sheep, 89.
Swine, bacon, 218; breeds of, 99 ; food requirements, 322 ; judging, 210 ; origin of, 99 ; pens for, 320 ; score card: fat hog, 212; types, 119, 123 . 209, 218.

Tamworth pig, 110.

Tankage, 311 .

Temperament in animals, 225 .

Therm, 270.

Thoroughbred horse, 27.

Thoroughpin, 153.

Timothy, 289.

Toe-crack, 155.

Toggenburg goat, 96 .

Tomkins family, 53.

Tunis sheep, 89 .

Turkeys, breeds of, 333 .

Turnip, 301.

Type, animal, and its importance, 114, 122; uniformity in. 236 .

Union Stock Yards, 13.

Variation in animals, 228.

Ventilation of stables, 319 .

Victoria pig, 111.

Water, in animal body, 261; in plants, 258; use of by ani. mals, 271 .

Watson, Hugh, 56.

Webb, Jonas, 80.

Wheat, 293, 306 .

Wheat bran, 306 .

Wild boar, 99 .

Wild White cattle, 46.

Wolff, 276; feeding standarls, $276,285$.

Tiool, 201.

Wyandotte fowls, 329 . 


\section{Agricultural TEXT BOOKS \\ FOR}

\section{HIGH SCHOOLS}

\section{WEBB PUBLISHING CO.,}

St. Paul, Minn.

This series of agricultural books, of which Beginnings in Animal Husbandry is a representative, is planned especially for high schools in which agriculture is taught. The books constitute a complete four-year graded course in agriculture. Each book is complete in itself, and its scope is well within the limits of the course. They are written by men eminent in their line, and who are well known for their clear and concise presentation of facts. Each of the books listed below has suggestive subjects for discussion and demonstration at the elose of each chapter. The series constitutes a complete, concise, and practical course that will meet the urgent needs of the modern agricultural high schools and of short courses in schools and colleges.

\section{FIELD CROPS}

$\mathrm{By}$

\section{A. D. WILSON,}

Superintendent of Farmers' Institutes and Extension,

Minnesota College of Agriculture, and

C. W. WARBLRTON,

Agronomist, U. S. Department of Agriculture.

544 pages, 162 ilustrations, cloth, $\$ 1.50$ net.

The aim of this book is to present the peculiarities of each of the various classes and varieties of farm crops, the handling of the soil, selections of seed, and general crop management. The book covers the cereals, including corn, wheat, oats, rye, barley, ete.; forage crops, including hay grasses, clover, alfalfa, cowpeas and ot her legumes; how to make good meadows and pastures, and the art of hay making, etc.; root crops; sugar crops; fiber crops, including cotton, flax, hemp; tobacco, potatoes, in fact every farm erop of any importance is discussed. The introduclory chapters are devoted to the general elassification of farm erops and their uses and relative importance, and reviews the subject of how plants grow. The concluding chapters discuss the theory and practice of crop rotation and weeds and their eradication. A list of the best supplementary reading, including farmers bulletins, is given at the close of each chapter. The style is easy, subject matter well arranged and vital, and the book is of excellent mechanical makeup) throughout. 


\section{SOILS AND SOIL FERTILITY}

By A. R. WHITSON, Professor of Soils and Drainage, College of Agriculture, University of Wisconsin, and H. L. WALSTER,

Instuctor of Soils, University of Wisconsin.

300 Pages, well illustrated, cloth, \$1.25 net.

Soils and Soil Fertility is a book especially prepared as a text book on the subject of Soils for high school courses in agriculture and short courses in colleges. There are chapters on the following subjects: Conditions Essential to Plant Growth, Origin and Classification of Soils; Primary Relations of Soil and Plant; Nitrogen; Phospholus and Potash; Soil Analyses; Farm Manures; Commercial Fertilizers; Physical Properties of Soils; Water Supply; Temperature and Ventilation of Soils; Drainage; Erosion; Tillage; Humus; Relation of Crops to Climate and Soils; Soils of the United States; Management of Important Types of Soil; Dry Farming. The explicit language of this book and the aroidance of complicating scientific data and techniral terms make it well within the comprehension of young students. They will find in it a fascinating study of soils and the practical ways of handling land to produce good crops. A well-chosen set of laboratory exercises and demonstrations, with complete directions, is also included. These are simple, easily carried out, and are fundamental. Well iliustrated, printed on high-grade paper, bound durably in cloth.

\section{AGRICULTURAL ENGINEERING}

\section{(In Preparation.)}

By J. B. DAVIDSON, Professor of Agricultural Engineering, Iowa State College.

5,0 pages, profusely illustrated, cloth, $\$ 1.50$ net.

The growing scarcity of farm labor is causing the farmer to invest most heavily in machinery and mechanical devices. This book aims to present in simple terms the engineering facts and principles that will insure successful practice and financial gain in farm management. Among the subjects discussed are: Agricultural Surveying, Drainage, Irrigation, Road Construction; Farm Machinery, including Elements of Machines, Materials and Lubrication, etc.; Wagons, Buggies, Pumps; Farm Motors; Steam and Gas Tractors; Farm Structures; and Farm Sanitation. The information is essentially practical and easily acquired. The book will train both the head and the hand.

\section{POPULAR FRUIT GROWING}

By SAIIUEL B. GREEN, late Professor of Horticulture and Forestry, University of Minnesota.

300 Pages, 120 illustrations, cloth, $\$ 1.00$ postpaid.

This book covers the factors of successful Fruit Growing, with lists of fruits adapted to each state; Orchard Protection, Injurious Insects and Diseases, Spraying, Harvesting and Marketing Methods, Propagation of Fruits, etc. A very popular book for schools and colleges. A new, revised edition by Le Roy Cady, Professor of Ilorticulture, University of Minnesota, is just out. 


\title{
OTHER STANDARD AGRICULTURAL BOOKS
}

\author{
AGRICULTURE FOR YOUNG FOLKS \\ By \\ A. D. WILSON and E. W. WILSON.
}

A thoroughly practical treatise on Elementary Agriculture dealing with the every-day problems of the farm.

This book avoids the vague generalities and scientific theories and treats each subject in a manner easily understood and readily applied to existing conditions on every farm. Prepared especially for beginners and contains many valuable suggestions which would prove interesting to the most experienced farm manager. Among the numerous subjects discussed are: Preparing the Soil; Seeding; Rotation; Care of Crops; Marketing; Farm Business; Management of Cattle; Roads; etc., etc. Over 300 pages profusely illustrated. Price, $\$ 1.00$ postpald.

VEGETABLE GARDENING, by Samuel B. Green, late Professor of Horticulture and Forestry, University of Minnesota. A manual on the growing of vegetables for home use and for the market. Profusely illustrated; 10th edition. Price, $12 \mathrm{mo}, 252$ pp., cloth, $\$ 1.00$ postpaid.

AMATEUR FRUIT GRONING, by Samuel B. Green. A practical guide to the growng of fruit for home use and the market, written with special reference to a cold climate. Illustrated. $13 \pm \mathrm{pp}$. Price, 12 mo. paper, 25 cents; cloth, 50 cents.

ELEMIENTS OF AGRICULTURE, by H. J. Shepperd and J. C. MeDowell: A complete treatise on practical agriculture, covering plant and animal breeding; thoroughly illustrated. A complete text book, adopted in public and agricultural schools throughout the Northwest. $12 \mathrm{mo}$., cloth, $100 \mathrm{pp}$. Price, \$1.00.

WEEDS AND HOW TO ERADICATE THEMI, by Thomas Shaw, giving the names of the most troublesome weed perts ealst and west and successful methods of destroying them. Price, 16 mo., 210 pp., cloth, 50 cents; paper, 25 cents.

FARM BLACLSIITHING. A complete treatise on blacksmithing by J. M. Drew. Written for farmers who want a workshop where they can profitably spend stormy days. Illustrated, 100 pl). Price, 12 mo., cloth, 50 cents.

STANDARD BLACKSMITHING, IIORSESIOEING AND WAGON MAKING, by J. G. Holmstrom, author of "Modern Blacksmithing," gives practical instructions by a successful blacksmith. 'T'le latest and most complete book on the subject published. Thoroughly illustrated. Price, 12 mo., cloth $\$ 1.00$.

THE COLNTRY KITCHEN. Nine hundred tried and tested recipes suited to the country and contributed by readers of 'The Farmer. The most popular and practical cook book on the market; $151 \mathrm{pp}$. I'rice, 12 mo., cloth, 50 cents; paper, 25 cents. 



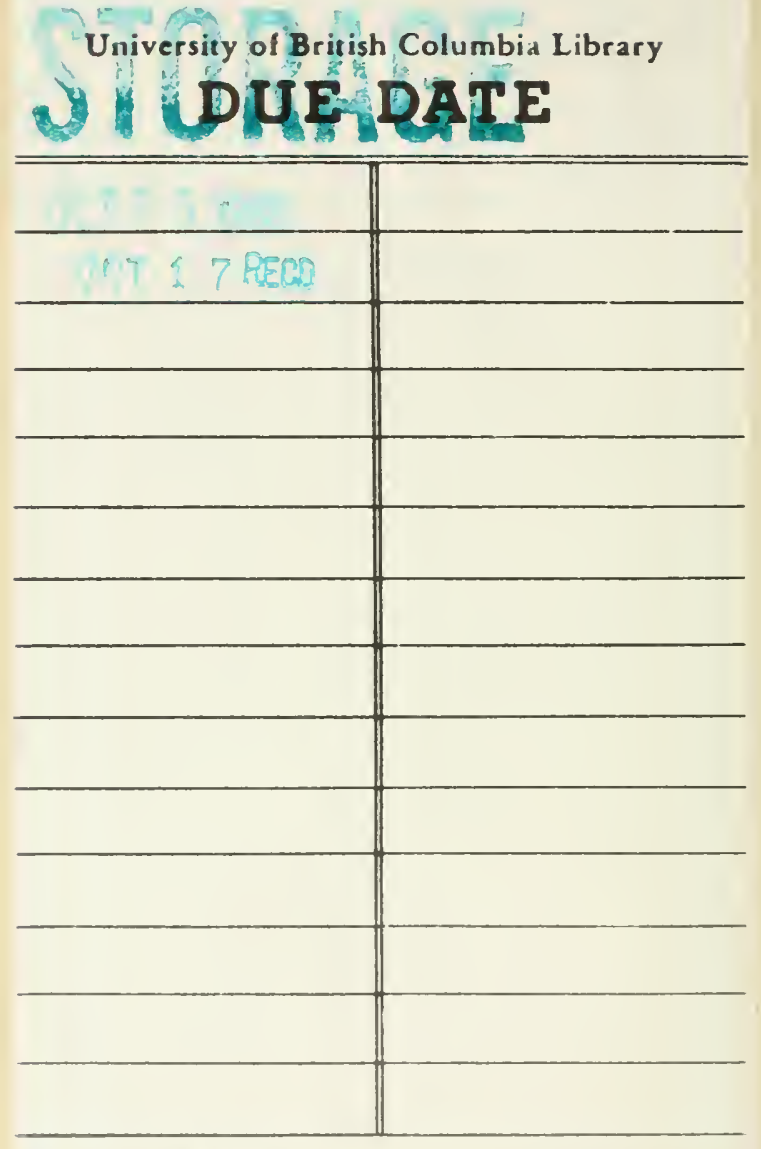

ET.6 BP 74.463 


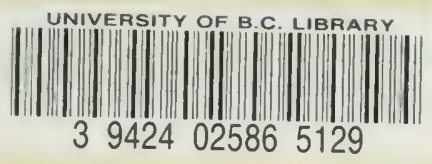

\section{LIBRARY}
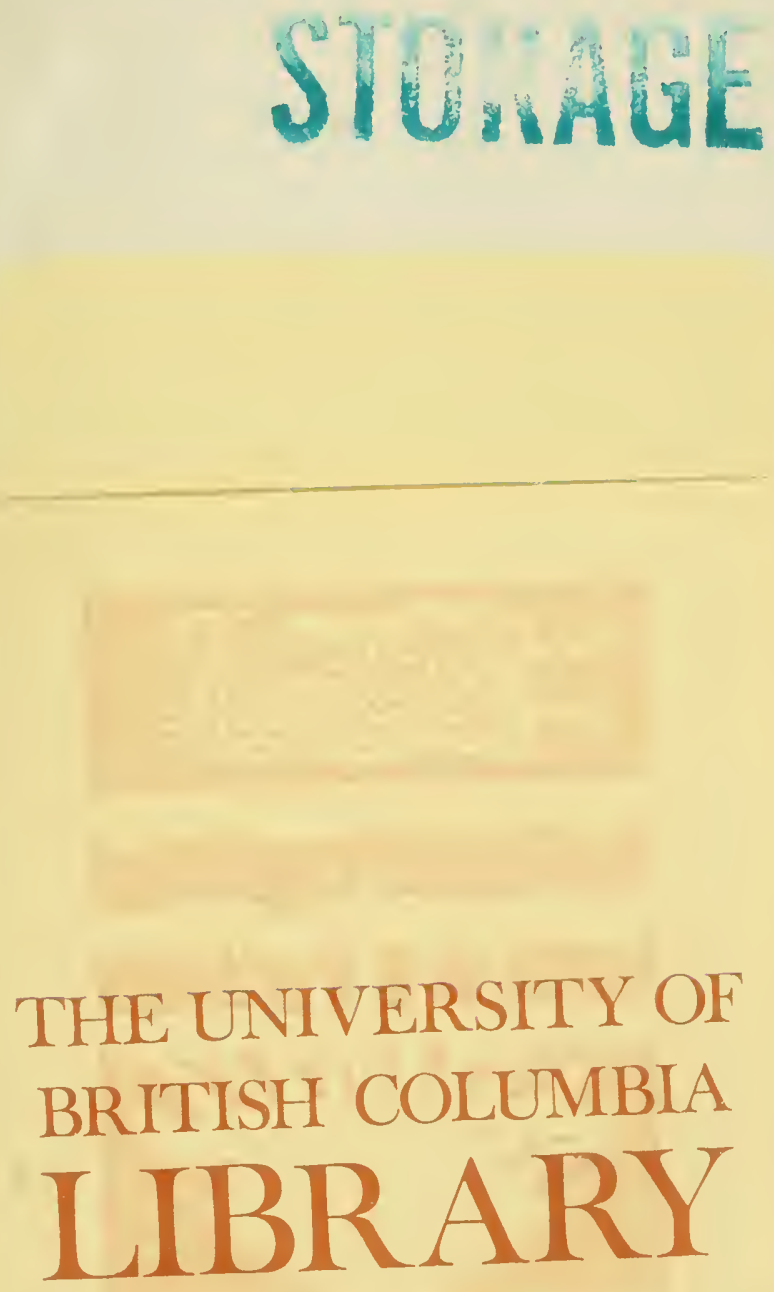
